UNIVERSIDADE DE SÃO PAULO

FACULDADE DE FILOSOFIA, LETRAS E CIÊNCIAS HUMANAS

DEPARTAMENTO DE LETRAS CLÁSSICAS E VERNÁCULAS

PROGRAMA DE PÓS-GRADUAÇÃO EM ESTUDOS COMPARADOS DE LITERATURAS DA LÍNGUA PORTUGUESA

\title{
A alquimia do "adultescer": a literatura para juventude como rito de passagem
}

\begin{abstract}
Sersi Bardari
Tese apresentada ao Programa de PósGraduação em Estudos Comparados de Literaturas de Língua Portuguesa da Faculdade de Filosofia, Letras e Ciências Humanas da Universidade de São Paulo, para a obtenção do título de Doutor em Letras.
\end{abstract}

Orientadora: Profa ${ }^{a}$ Dra . Maria Lúcia Pimentel de Sampaio Góes. 


\section{SERSI BARDARI}

\section{A alquimia do "adultescer": a literatura para juventude como rito de passagem}

Tese apresentada à Faculdade de Filosofia, Letras e Ciências Humanas da Universidade de São Paulo, para a obtenção do título de Doutor em Letras.

Área de concentração: Estudos Comparados de Literaturas de Língua Portuguesa.

Orientadora: Profa. Dra ${ }^{a}$. Maria Lúcia Pimentel de Sampaio Góes.

São Paulo 


\section{FOLHA DE APROVAÇÃO}

Sersi Bardari

A alquimia do "adultescer": a literatura para juventude como rito de passagem

Tese apresentada à Faculdade de Filosofia, Letras e Ciências Humanas da Universidade de São Paulo, para a obtenção do título de Doutor em Letras.

Área de concentração: Estudos Comparados de Literaturas de Língua Portuguesa.

Aprovado em:

Banca Examinadora

Prof. Dr.

Instituição Assinatura:

Prof. Dr.

Instituição Assinatura:

Prof. Dr. Instituição Assinatura:

Prof. Dr. Instituição Assinatura:

Prof. Dr. Instituição Assinatura: 


\section{PALAVRAS PRELIMINARES}

Escrever esta tese é, antes de tudo, fazer uma homenagem a meu pai Waldemar Sersi Manoel Bardari e a José Bento Monteiro Lobato. Ao primeiro, por ter me apresentado o segundo. Ao segundo, por ter contribuído para minha formação como ser humano, como cidadão, como profissional, enfim, como leitor do mundo. Trago em mim um pouco de cada uma de suas personagens: a irreverência e a curiosidade de Emília, as travessuras de Pedrinho, o lado sonhador de Narizinho, a necessidade da mata e a magia do Saci Pererê. Gosto de História e estórias, como dona Benta; de Geografia, como tia Nastácia, e anseio pela sabedoria de um Visconde de Sabugosa.

É por perceber-me assim, impregnado de Sítio do Pica Pau Amarelo, que fui buscar no conhecimento científico as respostas de que precisava para compreender a importância da literatura no desenvolvimento da personalidade, especialmente da criança e do jovem. No caminho dessa procura, reencontrei-me, vinte anos depois do primeiro contato, quando tive um de meus livros publicados por seu intermédio, com a Prof ${ }^{\mathrm{a}}$. $\mathrm{Dr}^{\mathrm{a}}$. Maria Lúcia Pimentel de Sampaio Góes, que há muito trilhava pelas veredas da Literatura para Jovens, tanto como artista exitosa quanto como docente e pesquisadora incansável e profícua. A ela, faço reverência, demonstrando todo meu agradecimento.

Por fim, agradeço ao escritor Lino de Albergaria, pelos enredos desenvolvidos em sua obra, que me possibilitaram encontrar refletido na arte o tema teórico com o qual, desde o princípio, eu objetivava trabalhar. 
O que sou agora é o que será usado para criar o meu eu, mais tarde*.

* De um poema de John D., 17 anos, apud BLOS, Peter. Adolescência: uma interpretação psicanalítica. São Paulo, Martins Fontes, 1998. 


\section{RESUMO}

\section{BARDARI, Sersi. A alquimia do "adultescer": a literatura para juventude como}

rito de passagem. 2008. f. Tese de Doutorado - Faculdade de Filosofia, Letras e Ciências Humanas, Universidade de São Paulo, 2008. (E-mail: sersi@uol.com.br)

Por meio deste trabalho, inserido na área de Estudos Comparados de Literaturas de Língua Portuguesa, objetivou-se estudar o modo como a Literatura para Juventude representa a passagem da adolescência para a idade adulta, tendo em vista a contribuição que os textos literários podem prestar para o processo de formação da subjetividade dos jovens, seja de modo realístico ou simbólico.

Em termos de referencial teórico, trabalhou-se com o pensamento de diversos estudiosos da Psicologia do Desenvolvimento, tanto daqueles cujos trabalhos ativeram-se à investigação do ego, quanto dos que foram além e professaram teorias a respeito do self e do processo de individuação.

No sentido de demonstrar a validade do mito do herói como estrutura narrativa simbólica do "adultescer", empreendeu-se estudo comparativo de O relógio do mundo, do autor brasileiro Lino de Albergaria, com Aventuras de João Sem Medo: panfleto mágico em forma de romance, de José Gomes Ferreira, obra clássica da Literatura Portuguesa.

Por meio da análise dos textos, construídos com base nas invariantes do conto maravilhoso, procurou-se demonstrar que, do ponto de vista da natureza psíquica, a conquista da maturidade é processo universal e atemporal, porém, o modo desta expressar-se no mundo está diretamente ligado com a cultura de cada lugar e época.

Palavras-chave: Literatura para Jovens; Conto Maravilhoso; Rito de Passagem; Mito do Herói; Psicologia do Ego; Psicologia do self; Processo de Individuação; Maturidade. 


\section{ABSTRACT}

\section{BARDARI, Sersi. The alchemy of "adulting": literature for youngsters as rite of}

passage. 2008. f. Doctorate Thesis - Faculdade de Filosofia, Letras e Ciências Humanas, Universidade de São Paulo, 2008.

Placed within the field of Comparative Studies on Literature Written in Portuguese, this work has studied how youth literature can represent the passage from adolescence to adulthood, considering the contribution that literary texts may give to the formative process of a youth's subjectivity, be it through realism or symbolism.

Regarding its theoretical background, the research relies on the ideas of several authors from the field of Developmental Psychology, both those whose works concentrated on investigating the ego, and those who took a further step towards theorizing on the self and the individuation process.

For the purpose of demonstrating how the myth of the hero serves as narrative structure to the process of "adulting", a comparative study has been undertaken between $O$ relógio do mundo, by the Brazilian author Lino de Albergaria, and Aventuras de João Sem Medo: panfleto mágico em forma de romance, a classic work from Portuguese literature by José Gomes Ferreira.

Such works, built upon invariable elements of the marvelous structure, reveal that reaching maturity, in terms of its psychic nature, is a universal and timeless process, nonetheless, the way it is expressed in the world is directly connected to the culture of each specific time and place.

Key words: Youth Literature; Marvelous Tale; Rite of Passage; Myth of the Hero; Psychology of the Ego; Psychology of the Self; Individuation Process; Maturity. 


\section{SUMÁRIO}

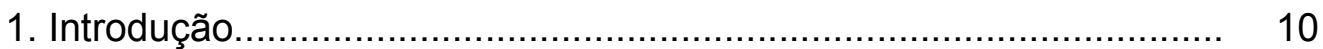

2. Ser adulto: o que isso significa? ................................................. 15

2. 1 Adolescência........................................................................... 18

2.1.1 Jean Piaget................................................................ 19

2.1.2 Peter Blos................................................................... 21

2.1.3 Arminda Aberastury.................................................... 34

2.1.4 Maurício Knobel......................................................... 37

2.1.5 Contardo Calligaris.......................................................... 45

2.2 Maturidade

2.2.1 John-Raphael Staude.............................................. 50

2.2.2 Erik Homburger Erikson.................................................. 52

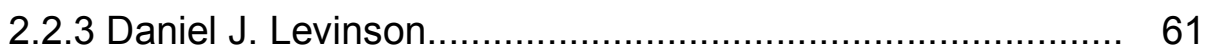

2.2.4 Terri Apter................................................................... 71

3. A alquimia do "adultescer" ...................................................... 79

3.1 O relógio do mundo: a transição de Casemiro............................... 80

4. O rito de passagem em tempo e lugar diferentes.............................. 154

4.1 Estudo comparativo............................................................. 158

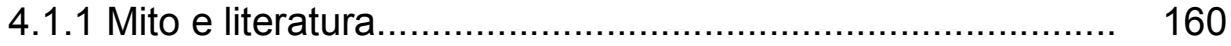

4.1.2 Invariantes do conto maravilhoso...................................... 165

4.1.3 A exemplaridade do mito............................................... 172

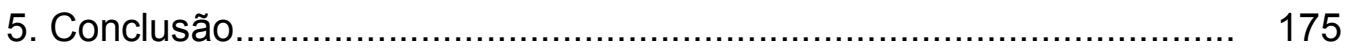

5.1 Maturidade segundo a psicologia do ego.................................. 178

5.2 Maturidade segundo a psicologia do self................................... 180

5.3 Maturidade segundo o contexto................................................. 182

6. Bibliografia............................................................................. 184

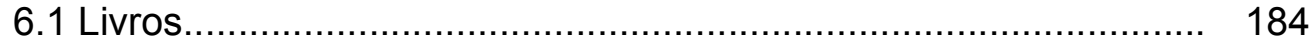

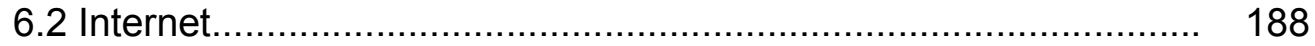

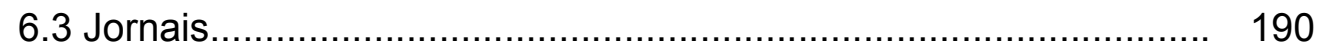

7. Apêndice: a obra de Lino de Albergaria......................................... 191

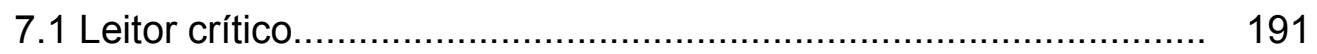

7.1.1 Cabelos de fogo, olhos de água...................................... 193

7.1.2 O menino e o mar............................................................ 195 
7.1.3 Urano x Netuno.

7.1.4 Chico, Edu e a oitava série.............................................. 199

7.1.5 Márika e a sétima série.................................................... 201

7.1.6 Lia e a sexta série.......................................................... 204

7.1.7 Miguel e a quinta série................................................... 206

7.1.8 Adeus, escola................................................................. 209

7.1.9 Maria Poliana............................................................ 211

7.1.10 De Paris, com amor................................................... 213

7.1.11 Uma história de amor................................................ 216

7.1.12 Caderno de segredos................................................. 218

7.1.13 Pio e Pinóquio....................................................... 222

7.1.14 Em busca do novo rei: um jogo literário........................... 224

7.1.15 Alice no metrô................................................................ 226

7.1.16 Um outro Marco Pólo..................................................... 228

7.1.17 O relógio do mundo....................................................... 231

7.1.18 O correspondente estrangeiro........................................ 234

7.1.19 Nosso muro de Berlim.................................................. 235

7.1.20 A outra menina.......................................................... 237

7.1.21 Uma cor dentro da terra............................................... 238

7.1.22 Crescendo na quadra................................................. 241

7.1.23 Tantas histórias tem o tempo... ..................................... 244

7.1.24 Cinco anos sem chover................................................. 246

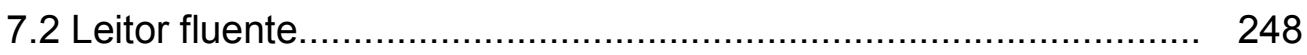

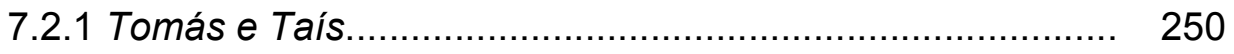

7.2.2 O livro das estrelas...................................................... 251

7.2.3 O mistério da mochila cor-de-abóbora................................ 254

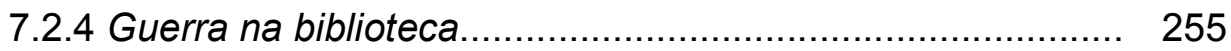

7.2.5 Um anjo no jardim..................................................... 257

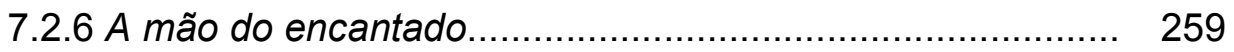

7.2.7 Um amor de menino....................................................... 261

7.3 Leitor-em-processo.............................................................. 262

7.3.1 Álbum de família......................................................... 264

7.3.2 A família invisível.......................................................... 265 
7.3.3 A boneca e o Saci............................................................ 267

7.3.4 Amanhã chega o sol................................................ 268

7.3.5 Violetas e alfazema......................................................... 269

7.3.6 A música lá de casa...................................................... 271

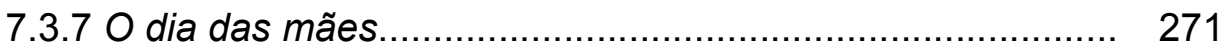

7.3.8 Histórias que se apagam................................................. 273

7.3.9 Histórias embaralhadas................................................. 274

7.3.10 A palavra perdida........................................................ 275

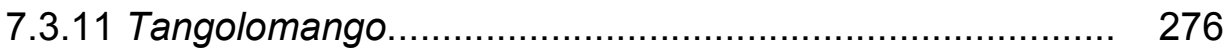

7.3.12 Quem era ela?.................................................. 278

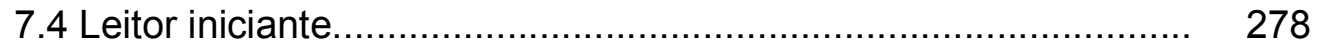

7.4.1 Coração conta diferente................................................ 280

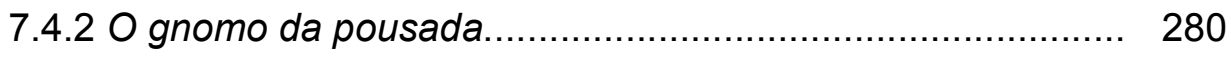

7.4.3 A praia dos duendes..................................................... 282

7.4.4 A caverna dos elfos...................................................... 283

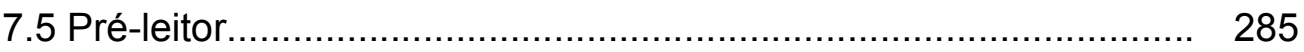

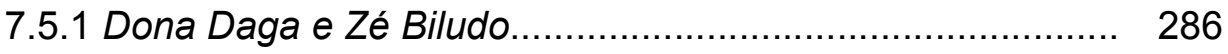

7.5.2 O sumiço do botão....................................................... 287

7.5.3 O bolo das vizinhas..................................................... 288

7.5.4 A galinha do vizinho e a vaca amarela.............................. 288

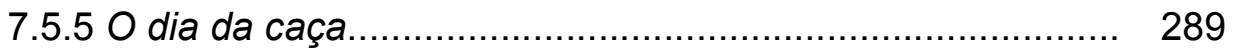

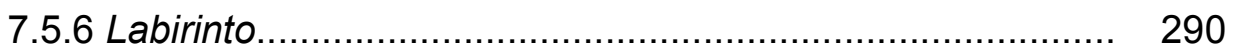

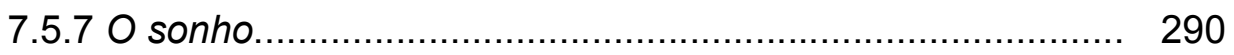

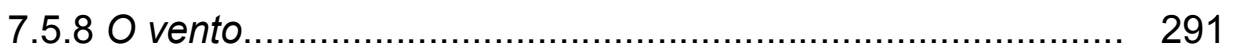

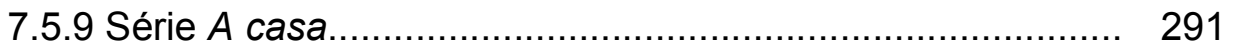

7.5.9.1 O espelho ..................................................... 292

7.5.9.2 O chuveiro............................................................. 292

7.5.9.3 A rede ....................................................... 292

7.5.9.4 A cadeira.................................................... 292

7.5.10 Túlio e a chuva............................................................ 293

7.5.11 Eurico ri à toa............................................................ 293

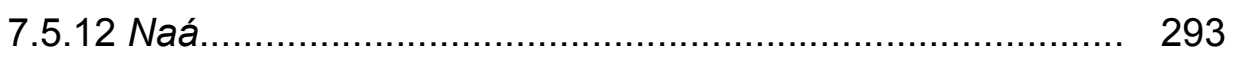

7.5.13 O patinho feio e outros contos de Andersen..................... 294 


\section{Introdução}

Por meio deste trabalho, inserido na área de Estudos Comparados de Literaturas de Língua Portuguesa, objetivou-se estudar o modo como a Literatura para Juventude representa a passagem da adolescência para a idade adulta, tendo em vista a contribuição que os textos literários podem prestar para o processo de formação da subjetividade dos jovens, seja de modo realístico ou simbólico. Especificamente, privilegiaram-se as obras de Lino de Albergaria e José Gomes Ferreira.

Como ponto de partida para a delimitação do tema, encontrava-se a inquietação para a busca de respostas a perguntas como: "O que significa ser adulto hoje em dia?", "Quais são as exigências e as prerrogativas para uma pessoa ser considerada adulta na sociedade contemporânea?", "O que se espera e o que não se espera de um adulto, no momento da cultura em que juventude é valor e meta a serem alcançados por quase todas as faixas etárias, inclusive pelas crianças?".

Por meio das leituras preliminares, e também da observação empírica, constatou-se que não há nas sociedades capitalistas hodiernas, globalizadas, ritos de passagem que demarquem para crianças e jovens os momentos finais e iniciais das diferentes fases do desenvolvimento psíquico e social. A reflexão corrente sobre o assunto entre educadores e psicanalistas apresenta aspectos favoráveis e desfavoráveis sobre a inexistência de rituais. $O$ abandono desses marcos institucionalizados representaria, de um lado, maior liberdade para o encontro de soluções particulares, por meio da busca de modelos comportamentais em diferentes fontes. De outro lado, entretanto, essa mesma liberdade poderia resultar em individualismo voraz, no exercício do qual questões relativas ao convívio comunitário ficariam sempre em segundo plano.

Entre esses dois extremos, acredita-se que a literatura para jovens tenha importante papel a cumprir. Mesmo sem incorrer no discurso didático-moralista, narrativas literárias, de qualquer gênero, podem auxiliar o leitor a encontrar referências para o crescimento individual e paradigmas de comportamento em sociedade. Sob esse aspecto, faz-se coro com que diz Mautner ${ }^{1}$ :

\footnotetext{
${ }^{1}$ MAUTNER, Ana Verônica. "Aprenda nos romances". Folha de S. Paulo, São Paulo, 20 set. 2007. "Folha Equilíbrio", p.12.
} 
[...] É próprio aos jovens ansiar por resolver a vida, surdos às pregações dos adultos. Daí a atemporal importância das fábulas e das parábolas na tarefa de orientar.

O jeito é palpitar por meio da ficção. É chegado o momento de editar livros que falem de angústias de gordinhos, medo do sexo oposto, pânico da humilhação. As conseqüências psicológicas dos conflitos familiares, de doenças, da morte e do abandono são temas aos quais a sabedoria das avós tem hoje pouco a acrescentar.

[...] Como o adulto não se sente eficiente para bem orientar os jovens, é chegada a hora dos artistas. Por meio daquelas histórias, o jovem pode, identificando-se, situar-se diante do moderno.

Sair da infância, adolescer e amadurecer é uma aventura para ninguém botar defeito. Parece-me que, diante da insegurança dos adultos, resta à literatura resgatar para o jovem a possibilidade de novas percepções sem obedecer à voz imperativa de um adulto.

$\mathrm{Na}$ pesquisa sobre quais livros deveriam figurar como objeto de estudo mais apropriado à finalidade com que se desenvolveu esta tese, destacou-se o conjunto da obra de Lino de Albergaria, especialmente pelas suas características temáticas. Marcados pela presença constante de personagens que se desenvolvem física, psíquica e espiritualmente, os livros do autor veiculam valores ideológicos consagradamente compreendidos como inerentes aos mais elevados princípios éticos do relacionamento humano. Dessa forma, a partir deles, foi possível suscitar discussões a respeito do processo de crescimento psicológico e do conceito de maturidade, ambos de concepção bastante polêmica nos dias atuais.

Lino de Albergaria ${ }^{2}$ é formado em Letras e Comunicação, com mestrado em Editoração, na Universidade de Paris, e doutorado em Literaturas e Língua Portuguesa, na Pontifícia Universidade Católica de Minas Gerais (PUC-MG). Nasceu em Belo Horizonte e morou durante algum tempo no Rio de Janeiro e São Paulo. Escreveu e publicou contos em suplementos literários e revistas de todo o país. Tem estórias infantis publicadas na Bélgica. É autor de dois romances para o público adulto e também fez várias traduções de originais franceses. A maior parte de seus livros, no entanto, é dirigida para infância e para a juventude. Até a data do fechamento deste trabalho, eram 65 livros - todos resenhados e classificados por

${ }^{2}$ Informações sempre atualizadas sobre a vida e obra de Lino de Albergaria estão disponíveis em: http://www.caleidoscopio.art.br/linodealbergaria/index.htm. Acesso em 27 out. 2007. 
tipo de leitor ${ }^{3}$ (ver apêndice) -, entre os quais se elegeu 0 relógio do mundo ${ }^{4}$, escrito em 1989, para uma análise aprofundada.

Pertencente à linha do conto maravilhoso, a narrativa de O relógio mundo é estruturada a partir do mito do herói, que metaforiza a transição para a idade adulta. A escolha do gênero não se deu de forma aleatória. Ao contrário, resultou da reflexão a respeito do sucesso que estórias de cunho mágico alcançaram nos últimos tempos no mercado editorial, de que Harry Potter, de J. K. Rowling, e Senhor dos Anéis, de J. R. R. Tolkien, são apenas alguns exemplos. Sobre esse retorno do maravilhoso, opina Coelho ${ }^{5}$ :

Não há como negar que estamos vivendo um momento propício à volta do maravilhoso. Lembremos que há pouco mais de um século a ciência positivista, aprofundando seu conhecimento a respeito das leis da natureza (Materialismo, Determinismo, Evolucionismo), tinha como um dos objetivos destruir a idéia de transcendência sobre a qual se funda (ou fundava?) a Civilização Cristã [...].

Mas a vida não pára. A contínua evolução das idéias e descobertas acabou por abalar aquelas "certezas absolutas" sobre as quais a Ciência materialista se alicerçava. No início do século $X X$, entramos na Era Einsteiniana - a era do Relativismo. As descobertas no campo da Física atômica abalaram os alicerces da Ciência tradicional (concepção mecanicista de Descartes e de Newton). Os dogmas positivistas caíram por terra.

Em termos de referencial teórico, trabalhou-se com o pensamento de diversos estudiosos da Psicologia do Desenvolvimento, tanto daqueles cujos trabalhos ativeram-se à investigação do ego, quanto dos que foram além e professaram teorias a respeito do self e do processo de individuação. A despeito das dissidências ocorridas no campo da Psicanálise clássica, de Sigmund Freud, e da criação gradual da Psicologia Analítica, por Carl Gustav Jung, a partir de 1913, diversos psicólogos consultados souberam perceber a linha de continuidade entre o trabalho de ambos. Entre esses, destaca-se Erik $H$. Erikson, que, apesar de seguir a corrente

${ }^{3}$ Pré-leitor, leitor iniciante, leitor-em-processo, leitor fluente, leitor crítico. De acordo com: COELHO, Nelly Novaes. Literatura infantil: teoria, análise, didática. São Paulo, Moderna, 2000, pp.32-41.

4 ALBERGARIA, Lino. O relógio do mundo. Ilustrações Rogério Borges. 13.ed., São Paulo, Atual, 1989, $64 \mathrm{p}$.

${ }^{5}$ COELHO, Nelly Novaes. O conto de fadas: símbolos, mitos, arquétipos. São Paulo, DCL, 2003, p. 15. 
psicanalítica, estabeleceu relações históricas e intelectuais entre Freud e Jung. Além dele, também Daniel J. Levinson encontrou fortes pontos de interconexão entre os dois grandes mestres da psicologia. Realizador de um dos mais completos estudos sobre a maturidade, Levinson e seu colaboradores basearam suas análises indiscriminadamente nas teorias do ego e do self. $\mathrm{Na}$ justificativa de seus procedimentos metodológicos, Levinson ${ }^{6}$ argumenta:

O cisma que durante muito tempo dividiu as várias escolas da psicologia profunda, e restringiu o alcance de cada ponto de vista, está talvez começando a cair por terra. O absurdo do antigo esforço sectarista é evidente.

Seguindo a idéia de Levinson, na elaboração deste trabalho, procedeu-se da seguinte forma: apresentou-se primeiramente o que psicólogos como Jean Piaget, Peter Blos, Arminda Aberastury, Maurício Knobel, Contardo Calligaris, John-Raphael Staude, Charlotte Bühler, Fred Massarik, Robert J. Havinghurst, Nevitt Sanfor, Erik H. Erikson, o próprio Daniel J. Levinson e Terri Apter pensam a respeito do desenvolvimento na adolescência e na vida adulta. $O$ estudo de alguns deles serviu como referência para a construção de resenhas sobre o conjunto da obra de Lino de Albergaria, conforme pode ser verificado pelas citações. Relativamente à análise de O relógio do mundo, optou-se por utilizar, de maneira exclusiva e aprofundada, os conceitos teóricos de Carl Gustav Jung e de seus continuadores, como Marie Louise von-Franz e James Hillman, em virtude da abrangência de possibilidades interpretativas que oferecem, ao incorporarem conteúdos etnográficos, mitológicos e simbólicos oriundos de diversas culturas e períodos históricos.

No sentido de demonstrar a validade do mito do herói como estrutura narrativa simbólica da passagem da adolescência para a vida a adulta, empreendeuse estudo comparativo de O relógio do mundo com a obra Aventuras de João Sem Medo: panfleto mágico em forma de romance ${ }^{7}$, de José Gomes Ferreira, texto clássico da Literatura Portuguesa, publicado pela primeira vez em livro no ano de 1933. Produzido, portanto, em época, lugar e contexto sócio-cultural diferentes daqueles nos quais foi criada a obra de Lino de Albergaria, a narrativa de Ferreira

${ }^{6}$ LEVINSON, J. Daniel et alii. The Seasons of a Man's Life. New York, Ballantine Books, 1978, p. 5.

${ }^{7}$ FERREIRA, José Gomes. Aventuras de João Sem Medo: panfleto mágico em forma de romance. 17.ed., Lisboa, Publicações Dom Quixote, 1991. 
também é construída com base nas invariantes do conto maravilhoso, por meio das quais foi possível elaborar a aproximação dos dois trabalhos literários. Dessa forma, procurou-se ratificar que, do ponto de vista da natureza psíquica, a conquista da maturidade é processo universal e atemporal, porém, o modo desta expressar-se no mundo está diretamente ligado com a cultura de cada lugar e época.

O estudo apresentado nas próximas páginas foi realizado com o intuito de contribuir com pais, professores e educadores empenhados no desenvolvimento de práticas de leitura que revelem e relevem a riqueza de significados presente em narrativas literárias. Deposita-se, portanto, esta tese ao acervo de pesquisas realizadas do campo da Literatura para Juventude, como forma de reafirmar o valor dessa arte maior que - para além de entreter e divertir - cumpre importante papel no processo de desenvolvimento da subjetividade das crianças e dos jovens. 


\section{Ser adulto: o que isso significa?}

Definir o que significa ser adulto, especialmente nos dias atuais, é tarefa das mais árduas. Antropólogos, educadores, filósofos, sociólogos, psicólogos debatem a respeito da questão sem que respostas unânimes e definitivas sejam aceitas. Todo e qualquer posicionamento relativo ao tema está sempre sujeito a controvérsia, dada a própria natureza indefinível do assunto. Pode-se, entretanto, expor algumas observações a respeito de como a idéia de maturidade vem sendo expressa na sociedade contemporânea.

Em princípio, a discussão sobre o "adultescer" passa necessariamente pela diferenciação e valorização entre velho e novo, tanto no âmbito do indivíduo quanto no da cultura de modo geral. Isso porque a conceituação do que seja o homem maduro parece estar estreita e permanentemente ligada às transformações sociais, que, como se sabe, são impulsionadas pelos avanços tecnológicos dos meios de produção.

No mundo ocidental, até a Idade Média, quando a língua corrente entre a população européia era o Latim Clássico, a sociedade dividia as fases da vida em várias faixas etárias. Segundo a iconografia e também o vocabulário da época, havia a idade dos brinquedos, a idade da escola, a idade do amor ou dos esportes da corte, a idade da guerra e da cavalaria, e as idades sedentárias, dos homens das leis, das ciências e dos estudos, representadas pelas imagens do velho sábio barbudo, diante de sua escrivaninha. Explica Ariès:

As idades da vida não correspondiam apenas a etapas biológicas, mas a funções sociais; sabemos que havia homens da lei muito jovens, mas, consoante a imagem popular, o estudo era uma ocupação dos velhos.

Já a partir do século XVI, em pleno Renascimento, parece ter havido uma diminuição das faixas intermediárias entre a infância e a vida adulta. A idade de sete anos marcava o momento em que a criança deveria entrar na escola ou começar a trabalhar, passando a receber atribuições parecidas com as dos adultos. Essa situação permaneceu até praticamente o século XVIII, quando ainda não havia diferenciação entre criança e adolescente. Tudo indica que, até esse período, o

${ }^{8}$ ARIĖS, Philippe. História social da criança e da família. 2.ed., Rio de Janeiro, LTC, 1981, p. 9. 
conceito de infância não estava relacionado a fatores propriamente biológicos e, sim, à idéia de dependência. Ou seja, o indivíduo só deixava a infância a partir do momento em que obtivesse condições independentes de subsistência. Por essa razão, "palavras ligadas à infância iriam subsistir para designar familiarmente, na língua falada, os homens de baixa condição, cuja submissão aos outros continuava a ser total: por exemplo, os lacaios, os auxiliares e os soldados" 9.

A adolescência, como período de transição, é fenômeno relativamente recente, surgido na Alemanha e na França em princípios do século $X X$, ainda conforme Ariès ${ }^{10}$ :

[...] a consciência da juventude tornou-se um fenômeno geral e banal após a guerra de 1914, em que os combatentes da frente de batalha se opuseram em massa às velhas gerações da retaguarda. A consciência da juventude começou com um sentimento comum dos ex-combatentes, e esse sentimento podia ser encontrado em todos os países beligerantes, até mesmo na América de Dos Passos. Daí em diante, a adolescência se expandiria, empurrando a infância para trás e a maturidade para frente.

De meados do século XX em diante, mais exatamente depois da Segunda Grande Guerra, o mundo ocidental passou a conviver com uma infinidade de produtos destinados a facilitar a vida pessoal e profissional das pessoas. O processo de consumo de tecnologia, que se iniciou de forma paulatina entre as classes mais favorecidas, foi ganhando velocidade e atingindo cada vez mais pessoas. Tanto o número de itens colocados no mercado quanto a quantidade de cada um deles que a indústria se tornou capaz de produzir só têm crescido desde então. Se, no início, os apelos comerciais estavam relacionados a eletrodomésticos e pequenos equipamentos de uso individual, logo se intensificaram as vendas de automóveis, linhas telefônicas, aparelhos de som, entre tantos outros produtos.

Nas décadas de 1.970 e 1.980 os produtos existentes foram sistematicamente aprimorados em curtíssimos prazos. Com o fim da Guerra Fria, recursos tecnológicos até então disponíveis apenas para as forças armadas das grandes potências e corporações mundiais foram realocados de modo a incrementarem a produção de bens de consumo popular. Nesse período, por exemplo, os

${ }^{9}$ Idem, ibidem, p.11.

${ }^{10}$ Idem, ibidem, pp.14-5. 
computadores passaram por uma verdadeira revolução. Dos primeiros protótipos, que ocupavam o andar inteiro de um edifício, chegou-se aos computadores pessoais, os chamados PCs, da sigla em inglês para "personal computer", dia a dia mais compactos e miniaturizados.

Para atender a esse desenvolvimento, a indústria de "software" acelerou seus investimentos no sentido de fornecer programas operacionais e/ou cumpridores de tarefas mais sofisticados e inteligentes. Do mundo dos negócios à área de saúde, do campo jurídico ao das finanças, da educação à cultura, das artes ao entretenimento e aos veículos de comunicação de massa, todos os setores da atividade humana foram beneficamente afetados pela evolução tecnológica. O fenômeno deu novo impulso ao avanço do maquinário industrial, dos equipamentos científicos, dos produtos colocados à disposição dos seres humanos, como por exemplos o telefone celular, o "ipod", a TV digital, e dos serviços a eles relacionados.

Os valores agregados a toda essa evolução sempre foram os da facilidade e da praticidade, como forma de estimular o consumo. Prometeu-se ao homem que, num futuro bem próximo, ele estaria liberto de muitas de suas ocupações, com tempo disponível para cuidar de si próprio, da sua evolução pessoal e a de sua família. Mas será que é isso o que vem ocorrendo? Será que o homem contemporâneo tem aproveitado o avanço do conhecimento nos mais variados campos do saber para encontrar-se com a maturidade de forma psiquicamente equilibrada? E o que significa, de fato, tornar-se adulto no mundo contemporâneo? Uma das formas de tentar responder essas perguntas é realizar um levantamento sobre o que alguns dos principais estudiosos da área da Psicologia do Desenvolvimento têm pensado a respeito do assunto, tanto em épocas passadas como na atualidade.

Durante o processo de pesquisa, verificou-se que os autores são unânimes em relacionar o desenvolvimento psíquico ao estágio de desenvolvimento social da cultura na qual o indivíduo vive. Todos ponderam que, a despeito de existir certa regularidade nos estágios evolutivos por quais passa o ser humano, é necessário levar em consideração aquilo que o mundo externo impinge sobre ele. Dessa forma, o que se entende por maturidade em um determinado estágio de evolução social pode se transformar ao ritmo e compasso da evolução da própria sociedade.

Estudos sobre o desenvolvimento adulto, como se pôde constatar, são relativamente recentes. Tanto no campo da Psicologia como no das Ciências 
Sociais, até bem pouco tempo havia a propensão de se considerar que a evolução psíquica atingia o grau mais elevado com a conquista da maturidade biológica, que supostamente demarcaria o início da vida adulta. Conforme explica Staude ${ }^{11}$, o termo "idade adulta" foi por muito tempo utilizado de modo bastante vago, como uma categoria abrangente para tudo o que acontecia com o indivíduo após atingir a idade de 21 anos. A própria expressão, segundo ele, não tem nada dos sentidos que se percebe em vocábulos como "infância" e "adolescência". Para o autor, que escreve no início década de 1.980, não faz muito tempo que psicólogos do desenvolvimento do ciclo vital começaram a registrar e a analisar as fases do desenvolvimento adulto.

Sabemos alguma coisa sobre a adolescência, a transição da infância para a idade adulta; entretanto, sabemos muito pouco sobre a transição da meia-idade, e menos ainda sobre a transição pós-menopausa, na idade avançada. Afinal, a idade adulta na sociedade contemporânea em geral é vista de uma maneira demasiado indiscriminada. Ainda carecemos de uma teoria mais ampla sobre o desenvolvimento adulto. ${ }^{12}$

Na elaboração deste trabalho, por meio do qual se propõe interpretar de que modo a literatura para jovens contribui para o processo de construção da maturidade, julga-se importante compilar informações teóricas sobre as diferentes fases do desenvolvimento psicológico. Em específico, vale demonstrar como alguns estudiosos descreveram o período compreendido entre a adolescência e o ingresso na vida adulta.

\subsection{Adolescência}

Entre os que se dedicaram a investigar o desenvolvimento psicológico na adolescência, foram selecionados pesquisadores de épocas e nacionalidades distintas, como forma de compor um painel sobre a compreensão do comportamento do jovem em contextos culturais diferenciados. Dada a importância que seu nome conquistou na área de Educação, iniciou-se este levantamento pelo pensamento de Jean Piaget.

${ }^{11}$ STAUDE John-Raphael. O desenvolvimento adulto de C. G. Jung. Trad. Humberto Arcanjo Brito Rodrigues e Sílvia Helena Azarite Vianna. São Paulo, Cultrix, 1995, p. 8.

${ }^{12}$ Idem, ibidem. 


\subsubsection{Jean Piaget}

Psicólogo e epistemologista suíço de renome mundial Piaget ${ }^{13}$ caracteriza a adolescência como a fase pré-adulta durante a qual o indivíduo passa por processos de transformação profunda em dois campos específicos: o do pensamento e suas operações, e o da afetividade da personalidade no mundo social dos adultos.

Referentemente ao primeiro, Piaget ${ }^{14}$ explica que a construção dos sistemas que caracterizam a adolescência se dá, antes de tudo, pela transformação do pensamento concreto, próprio da infância, em pensamento "formal" ou "hipotéticodedutivo", ocorrida por volta dos 11 ou 12 anos. Somente depois disso é que o indivíduo está apto a construir sistemas e "teorias". A partir de então o adolescente passa a ter interesses por problemas inatuais, isto é, sem relação com as realidades vividas no cotidiano, ou por questões que antecipam, de forma quase sempre ingênua, as situações futuras do mundo.

Há nessa fase o egocentrismo intelectual do adolescente, como conseqüência ainda das formas de capacidade da vida mental típicas do lactente, que assimila o universo a sua atividade corporal, e da primeira infância, que assimila as coisas ao pensamento em formação. O egocentrismo adolescente manifesta-se pela crença na onipotência da reflexão, como se o mundo devesse submeter-se aos sistemas e não esses à realidade. No entanto, é ainda durante a adolescência que se estabelece o equilíbrio entre pensamento formal e realidade. Isso se dá quando a reflexão compreende que sua função não é a de contradizer, mas sim a de se adiantar e interpretar a experiência.

Paralelamente a essa elaboração do pensamento formal, na área da afetividade, o adolescente afirma-se através de dupla conquista: da personalidade e de sua inserção na sociedade adulta. Ao tratar do assunto, Piaget ressalta a diferença que os psicólogos estabelecem entre o "eu" e a personalidade. Nesse sentido, o "eu" seria o centro da própria atividade, caracterizando-se por seu egocentrismo, consciente ou inconsciente. Em posição oposta estaria a

${ }^{13}$ PIAGET, Jean. Seis estudos de psicologia. Trad. Maria Alice Magalhães D’Amorim e Paulo Sérgio Lima Silva. 24 ed., Rio de Janeiro, Forense Universitária, 2002, pp. 57-65.

${ }^{14}$ Idem, ibidem. 
personalidade, cujo desenvolvimento resulta da auto-submissão do "eu" a uma disciplina qualquer.

Para Piaget ${ }^{15}$, a personalidade começa no fim da infância, com a organização autônoma das regras, dos valores, da afirmação da vontade, e com a regularização e hierarquização moral das tendências. Segundo o psicólogo, existe personalidade a partir do momento em que se forma um "programa de vida", funcionando como fonte de disciplina para a vontade, em forma de instrumento de cooperação. Isso só se torna possível a partir da existência do pensamento hipotético-dedutivo.

Nessa fase do desenvolvimento, entretanto, a personalidade ainda é afetada pelo egocentrismo. $\mathrm{O}$ adolescente, embora se coloque em igualdade com os mais velhos, sente-se diferente deles. Justamente pela vida nova que o move e o estimula, sente-se inclinado a empreender grandiosos planos de reformas políticas ou sociais. Por essa razão, seus sistemas e projetos de vida são plenos de sentimentos generosos, altruístas ou de fervor místico e, ao mesmo tempo, de inquietante megalomania consciente.

Normalmente, fala-se da adolescência como se o impulso do instinto de amar fosse o traço mais característico desse período do desenvolvimento. Mas, segundo Piaget, embora o adolescente descubra em certo sentido o amor, mesmo nos casos em que esse amor encontra um objeto, o que se dá é a projeção de todo um ideal em um ser amado, daí as decepções tão repentinas e sintomáticas.

Há na vida do adolescente uma fase inicial de interiorização, que faz com que o indivíduo nesse estágio de desenvolvimento pareça anti-social. Contudo, Piaget ${ }^{16}$ acredita que essa interpretação seja de todo falsa, pois o adolescente medita o tempo todo sobre a sociedade real, condenando-a, uma vez que se preocupa apenas com aquela sociedade que sonha reformar. Dessa forma, a sociabilidade do adolescente afirma-se de modo preferencial por meio do contato dos jovens entre si, em associações voltadas para reflexões sobre a realidade, que podem se desenvolver em organizações mais amplas e, eventualmente, darem origem a grandiosos movimentos de juventude.

De acordo com Piaget, o adolescente só estará de fato adaptado à sociedade quando seu espírito reformador transformar-se em espírito realizador. É por meio da experiência que o indivíduo se torna capaz de reconciliar o pensamento formal com

${ }^{15}$ Idem, ibidem.

${ }^{16}$ Idem, ibidem. 
a realidade das coisas. Para tanto, o ingresso no mundo do trabalho profissional desempenha papel preponderante. Afirma o pesquisador:

Se os estudos especializados não são sempre suficientes, o trabalho profissional, uma vez superadas as últimas crises de adaptação, restabelece seguramente o equilíbrio e marca, assim, o acesso à idade adulta em definitivo. ${ }^{17}$

A despeito da afirmação acima, Piaget, entretanto, não menospreza a fase anterior de devaneios e sonhos que caracteriza determinado período da vida do adolescente. Continua ele:

[...] percebe-se, em geral, comparando-se as realizações dos indivíduos a seus antigos comportamentos de adolescentes, que aqueles que, entre quinze e dezessete anos, nunca construíram sistemas inserindo seu programa de vida em um vasto sonho de reformas, ou aqueles que, no primeiro contato com a vida material, sacrificaram seus ideais quiméricos a novos interesses adultos, não foram os mais produtivos. ${ }^{18}$

A partir dessa constatação, afirma-se o papel da literatura no sentido de servir como elemento catalisador para que os jovens construam, mesmo que de forma fantasiosa e utópica, um "programa de vida" baseado em reformas sociais.

\subsubsection{Peter Blos}

Ao apresentar suas interpretações psicanalíticas sobre a adolescência, o norte-americano Peter Blos ${ }^{19}$ classifica essa etapa da vida em diferentes fases. Inicia pelo período da latência, passando por pré-adolescência, adolescência inicial, adolescência propriamente dita, final da adolescência, até o período que ele chama de pós-adolescência. Para ele, a duração de cada uma dessas fases não pode ser fixada por critério de faixa etária, porém subsiste a elas uma seqüência ordenada de desenvolvimento psicológico. $\mathrm{O}$ adolescente pode transcorrer de maneira rápida por

${ }^{17}$ Idem, ibidem, p. 64.

${ }^{18}$ Idem, Ibidem, p. 64.

${ }^{19}$ BLOS, Peter. Adolescência: uma interpretação psicanalítica. 2.ed., São Paulo, Martins Fontes, 1998, pp. 71-214. 
todas as etapas ou desenvolver variações em qualquer uma delas, de modo a demorar-se mais em uma do que em outra. Ao compilar as idéias de Blos, no presente trabalho, não se tem a pretensão de aprofundamento nas teorias da Psicanálise que buscam explicar as causas comportamentais dos jovens. Pretendese apenas relacionar as formas de conduta adolescente descritas em cada estágio do desenvolvimento.

\section{Latência}

A fase de latência tem esse nome porque, em termos psicanalíticos, interpretava-se anteriormente tratar-se de um período destituído de necessidades sexuais. Porém, essa idéia foi substituída pela compreensão de que há nessa fase um controle crescente do ego e do superego sobre a vida dos instintos, quando as energias mentais da criança estão mais concentradas no mundo interior do que em objetos exteriores.

Entre as conquistas da fase de latência encontra-se o desenvolvimento de um senso de auto-estima, derivado das realizações e habilidades que conquistam aprovação objetiva e social. A criança torna-se mais capaz de manter seu equilíbrio narcísico de maneira relativamente independente. Há maior estabilidade de afetos e de estados de espírito. Consolidam-se melhor as capacidades de percepção, aprendizado, memória e pensamento. A ambivalência característica da infância, segundo a qual tudo é inteiramente bom ou mal, feio ou bonito, isto é, nada é relativo, declina acentuadamente. Desenvolvem-se de maneira autônoma as funções mentais superiores, manifestadas em comportamentos e atitudes motivados pela lógica e orientados para valores. Como resultado, reduz-se de maneira significativa o uso do corpo como instrumento de expressão da vida interior, que passa a ser externada pela expressão oral isoladamente da atividade motora. Em outras palavras, há um aumento da desenvoltura no emprego da linguagem verbal, com o uso inclusive de metáforas.

Em síntese, são bastante acentuadas e evidentes as modificações de comportamento que ocorrem no período de latência, conforme ressalta Blos. ${ }^{20}$

${ }^{20}$ Idem, ibidem, p. 75. 
Um avanço da consciência social da criança em latência se faz lado a lado com a separação entre o pensamento racional e a fantasia, com a separação entre o comportamento do mundo público e o mundo privado em suma, com uma diferenciação nova, intensamente sentida. Nessa diferenciação a criança apreende facilmente as instituições sociais normativas, como educação, escola e playground, como um modelo de valor que promoverá seu comportamento integrativo.

\section{Pré-adolescência}

A volta da pressão dos impulsos genitais marca o fim do período de latência. A partir de então, qualquer experiência pode tornar-se sexualmente estimulante. Até mesmo atividades, fantasias e pensamentos destituídos de qualquer conotação erótica óbvia são filtrados pelos instintos sexuais. Ainda não se trata da realização do amor, mas, sim, de uma preocupação inconsciente e pré-consciente com os órgãos sexuais, sua função, integridade e proteção.

Essa pulsão, no entanto, irá defrontar-se com o superego desaprovador, desviando o pré-adolescente para o desenvolvimento de interesses e habilidades que possam contar com o abono social e, ao mesmo tempo, compensar a ansiedade. Comportamentos obsessivos são típicos dessa fase. Um exemplo é a compulsão para colecionar objetos das mais variadas naturezas. Outra característica é a tentativa de dissolver a culpa entre a turma de amigos - em geral já formada desde o período de latência - ou, mais especificamente, de lançá-la sobre o líder do grupo, colocando-o no papel de instigador dos atos de transgressão.

Uma vez que as transformações psíquicas da pré-adolescência são motivadas pela pulsão sexual, obviamente, meninos e meninas irão apresentar padrões de comportamentos diferentes. A tendência dos meninos é a de negarem a ansiedade em vez de procurarem estabelecer relação com o que sentem. Essa talvez seja a razão por que muitos deles se tornam agitados, inquietos, indiferentes pela limpeza, fascinados pela linguagem chula e por jogos fálicos. Para se defenderem de uma espécie de medo e inveja que sentem do sexo oposto, em geral, formam grupos de amigos exclusivamente masculinos, que se manifestam de 
modo a hostilizar, menosprezar e tentar evitar as meninas. Na presença delas, tornam-se orgulhos, arrogantes, provocadores e exibicionistas. Explica Blos ${ }^{21}$ :

É precisamente essa solução defensiva do menino, subjacente ao seu comportamento grupal típico, que foi classificada pela psicologia descritiva como "fase da gangue" [diferente da gangue de rapazes adolescentes mais velhos].

Com relação às meninas, nota-se uma exacerbação da atividade, ou seja, elas tornam-se praticamente muito ativas, numa evidente representação das atitudes próprias do mundo dos homens. Como resultado, o que se observa são préadolescentes masculinizadas ou jovens mulheres de comportamento agressivo. Referentemente à pulsão instintivo-sexual, as garotas atuam no sentido de substituir a curiosidade franca e o diálogo aberto pelos cochichos e segredos. Partilhar um segredo cujo conteúdo seja de natureza sexual é uma forma de intimidade e de conspiração durante essa fase.

A pré-adolescência configura-se, de certo modo, como período preparatório para as modificações que ocorrerão durante a adolescência, quando se observam a maior amplitude e o enriquecimento da vida emocional, a tentativa implacável de autodefinição e a passagem para o primeiro plano das relações fora do ambiente familiar. A diferença entre as duas etapas é apontada por Blos ${ }^{22}$ da seguinte maneira:

[...] o que distingue esse período [a adolescência] da fase de préadolescência é, portanto, a passagem de um aumento de pulsão meramente quantitativo para o aparecimento de uma qualidade de pulsão nitidamente nova. [...] Essa mudança na organização das pulsões acaba por dar à genitalidade um lugar de primeira ordem.

O limiar entre uma fase e outra é permeado pela transformação da satisfação auto-erótica em satisfação relativa ao outro, o que leva o indivíduo a fazer escolhas.

${ }^{21}$ Idem, ibidem, p. 89.

${ }^{22}$ Idem, ibidem, p. 97. 
Essa passagem gera situações conflitivas as quais, segundo Blos ${ }^{23}$, explicariam a ambivalência comportamental típica do adolescente.

Polaridades como as seguintes, como se sabe, surgem no mesmo indivíduo: sujeição - rebelião, sensibilidade delicada - grosseria emocional, espírito gregário - retraimento para a solidão, altruísmo - egoísmo, otimismo sem limites - desesperança total, apegos intensos - súbitas infidelidades, grande ideais - mesquinharia, idealismo - materialismo, dedicação - indiferença, aceitação de impulso - rejeição de impulso, apetite voraz, indulgência excessiva - autonegação cruel (ascetismo), exuberância física - inércia. Esses padrões de comportamento oscilantes refletem modificações psicológicas que não se processam nem em linha reta, nem em ritmo constante.

Como ingredientes essenciais dos dois estágios evolutivos, apontam-se a crescente autoconsciência social, acompanhada de angústia e culpa concomitantes; as dificuldades nas relações com o mundo exterior; a necessidade de ser amado, que só gradualmente se funde com a necessidade de amar, e a substituição parcial e paulatina do papel passivo de ser controlado pelo controle ativo das situações circundantes.

\section{Adolescência inicial}

Um dos fatores que marcam a fase inicial da adolescência é o fim do amor incestuoso, edípico, com a conseqüente tentativa de projeção da libido para relações fora do âmbito familiar. Essa separação dos pais, ainda que ocorra apenas no nível interno, psíquico, pode causar angustiante sentimento de vazio ou mesmo agitação interior, provocando baixa persistência em interesses e da criatividade. Ao mesmo tempo, há uma procura desajeitada por novos valores e pelas oportunidades de alívio das tensões que o ambiente externo venha a oferecer. Referentemente às leis morais, aos padrões de comportamento, à tomada de atitudes, busca-se nesse momento considerável independência com relação à autoridade dos pais. Surge uma onda de amizades íntimas, idealizadas e erotizadas, com indivíduos do mesmo sexo.

${ }^{23}$ Idem, ibidem, p. 101. 
Para o menino, o amigo ideal, diferente do companheiro de aventuras da préadolescência, apresenta alguma qualidade que ele admira e também gostaria de possuir. Uma vez incorporado em si os aspectos desejados, o amigo reduz-se às suas proporções comuns. Para a menina, a falta ou a perda de uma amiga pode levar ao desespero e à depressão. Neste caso, a forma típica de idealização assume contornos de uma espécie de paixão, em que se espera total disponibilidade de atenção e afeição da outra parte. Trata-se, segundo Blos ${ }^{24}$, da "fase bissexual intermediária da adolescência inicial feminina".

\section{Adolescência propriamente dita}

O estabelecimento de uma relação heterossexual, possibilitado pelo abandono das posições narcísicas e bissexuais, caracteriza o desenvolvimento psicológico da adolescência propriamente dita. Até atingir esse estágio, no entanto, o adolescente terá passado por situações várias que lhe dão o suporte psíquico necessários para tal realização.

Em primeiro lugar, deverá ter abandonado definitivamente os objetos de amor infantis, o que nem sempre ocorre com certa facilidade. Os desejos edípicos e seus conflitos inerentes voltam a surgir. A necessidade de resolvê-los faz com que a energia anteriormente projetada na representação do papel dos pais volte-se para si próprio. Esse fato, conseqüentemente, gera o aumento do narcisismo, que pode ser observado em ambos os sexos. Atitudes narcísicas atuam como fator de proteção em duas circunstâncias básicas. Inicialmente, trata-se de um mecanismo de defesa contra a incapacidade sentida pelo adolescente de abrir mão da segurança representada pelos pais, o que o leva desiludir-se consigo próprio, em virtude de sua limitada realização concreta na realidade. Em segundo lugar, são preventivas contra a decepção, a rejeição e o fracasso no jogo do amor.

A fase narcisista é, dessa forma, conseqüência da dissolução da energia mental relativa à representação das figuras parentais. No intuito de livrar-se do pai ou da mãe internalizados, o adolescente estabelece identificações com objetos externos, reais ou imaginários, aos quais se apega de maneira transitória. Fenômeno comum nesse período é a sensação de fome exagerada (que só em

${ }^{24}$ Idem, ibidem, p. 112. 
parte está condicionada ao crescimento físico) alternada por períodos de inapetência. A flutuação do apetite está relacionada com o aumento e declínio da necessidade dos pais.

O narcisismo, na maior parte das vezes, manifesta-se em forma de arrogância, rebeldia e questionamento da autoridade dos pais. Esse padrão de comportamento, quase sempre recriminado, é, no entanto, fundamental para a manutenção da auto-estima, condição necessária ao desenvolvimento gradual da capacidade de encontrar o amor fora do ambiente familiar. Reafirma-se, assim, a importância do narcisismo para promover o processo de desligamento dos pais. Conforme esclarece Blos ${ }^{25}$, o "processo de separação e seu fascínio é que dão à fase narcísica sua qualidade positiva e progressiva".

Acompanham essa etapa os pensamentos fantasiosos e os devaneios extremamente ricos, que ajudam o adolescente a assimilar gradualmente as experiências afetivas. O perigo da fantasia é o seu caráter ambíguo de atuação. Se, por um lado, pode impulsionar a expressão artística e a criatividade, por outro, pode provocar sentimentos de alheamento, de irrealidade e de despersonalização, que levam muitos adultos a enxergarem na adolescência comportamentos de características psicóticas. Em sua forma positiva, a fantasia desempenha importante papel como mediadora da participação social. Sob o aspecto negativo, representa risco de regressão ao apego exagerado às figuras parentais internalizadas. O modo de manifestação da fantasia dependerá fundamentalmente do contexto social no qual está inserido o adolescente, incluindo-se aí classe social, região geográfica, época histórica, relacionamento com os pais, entre outras situações que implicam valores.

Blos ${ }^{26}$ cita como exemplo de realização da fantasia o hábito de escrever um diário, mais comum entre as meninas, segundo o psicanalista, somente por questões de tabus sexuais. Para ele, o diário ocupa posição intermediária entre o devaneio e o mundo externo, entre o faz-de-conta e a realidade.

[...] Os diários são representações deformadas por tendências conscientes ou não, exatamente como sonhos, fantasias e produções poéticas de adolescentes. [...] os diários também conseguem transmitir o

${ }^{25}$ Idem, ibidem, p. 124.

${ }^{26}$ Idem, ibidem, p. 128. 
tom do sentimento que acompanha as transformações físicas e emocionais de uma maneira que nenhum discurso teórico poderá igualar. ${ }^{27}$

Considerando que suas teorias vieram à luz no início década de 1960 e tendo em vista a influência das circunstâncias culturais no modo de expressão dos devaneios, podem-se compreender como correlatos atuais do diário os vários veículos cibernéticos de comunicação colocados a serviço da expressão da subjetividade e da interatividade, tais como blogs, fotologs, chats, redes de relacionamentos, mensageiros instantâneos, jogos, entre outros. Entre os usuários desses espaços virtuais, onde se pode exercer livremente a fantasia, é notório que os adolescentes estão em maior número.

Faz parte ainda da fantasia característica dessa fase a tendência a estabelecer relacionamentos fictícios. Em outras palavras, o adolescente elege pessoas às quais atribui qualidades, para que, por intermédio delas, tente liberar seus instintos passionais e agressivos. Em geral, essas relações terminam sem sofrimento e nenhuma espécie de conseqüência psíquica, atestando o fato de que as pessoas são consideradas mais como representações de imagens do que propriamente como seres humanos. É nesse sentido que se pode explicar o fenômeno contemporâneo do "ficar", isto é, a troca de carícias íntimas sem compromisso e, em muitos casos, sem envolvimento afetivo. Vale notar que, na atualidade, essa prática tem sido comum não somente entre os adolescentes, o que corrobora para a interpretação do valor extremado que o mito da juventude eterna tem para a sociedade do século XXI.

A partir dessa circunstância, o caminho do desenvolvimento passa pela experiência de vivenciar um amor-ternura. A escolha da pessoa para a qual se dirige essa paixão é determinada, geralmente, por alguma semelhança ou diferença notável, física ou mental, daquela com o pai ou a mãe. Esse novo componente irá modificar o padrão de atitudes dos jovens, em razão de um enriquecimento e refinamento da vida sentimental. No rapaz, por exemplo, as atitudes agitadas e barulhentas paulatinamente vão dando lugar a um sentimento erótico que entusiasma e inibe ao mesmo tempo. Ele sente pela parceira muito mais do que atração sexual. Enxerga nela uma mistura de atributos sagrados e preciosos, determinados em grande parte pela relação que estabeleceu com a mãe.

${ }^{27}$ Idem, ibidem, p. 130. 
Acompanha esse novo sentimento certo medo de rendição emocional e de submissão. O adolescente reage a esse temor afiliando-se a grupos essencialmente de homens nos quais possa reafirmar seus poderes e prerrogativas masculinas. Já a menina, ainda sobre a influência do conflito edípico, acredita compreender melhor o pai do que a própria mãe, com quem mantém uma relação de competitividade. Esse fato influencia suas escolhas. Não é incomum sentir-se atraída por meninos cuja principal qualidade é a de serem incompreendidos pelos outros. Para a garota, esse período é marcado ainda pela experiência bastante intensa da menarca, à qual reage emocionalmente, segundo Blos ${ }^{28}$, por meio de dois processos psíquicos: "a renúncia à dependência materna e a identificação com a mãe como o protótipo reprodutivo".

Pela ótica psicanalítica do desenvolvimento, explica Blos ${ }^{29}$ :

O declínio do complexo de Édipo na adolescência é um processo lento e que chega até a fase do final da adolescência. Provavelmente só é concluído quando, no curso natural dos acontecimentos, o indivíduo se restabelece numa nova família.

Enquanto isso não ocorre, o jovem sente sua integridade ameaçada, já que os padrões de comportamento e sentimento da infância já não the servem mais como modelos de referência para estar no mundo. Como recurso compensatório, são iniciados processos de restituição que, paulatinamente, transformam-se em defensivos e adaptativos. Entre esses, destacam-se 0 ascetismo e a intelectualização, presentes de maneira predominante nas culturas em que o período da adolescência é normalmente prolongado devido às exigências de formação educacional. Segundo o psicanalista ${ }^{30}$, o ascetismo atuaria no sentido de refrear os instintos sexuais e explorar as tendências masoquistas. Já a intelectualização possibilitaria a relação dos processos instintivos com os conteúdos dos ideais, facilitando a tomada de consciência e o controle sobre o desejo sexual.

Uma vez que os mecanismos de compensação estão relacionados com o contexto sócio-econômico, histórico e cultural no qual está inserido o adolescente, o modo como eles se processam pode-se modificar de maneira substancial. Em

${ }^{28}$ Idem, ibidem, p. 147.

${ }^{29}$ Idem, ibidem, p. 148.

${ }^{30}$ Idem, ibidem, p. 150. 
grupos sociais mais permissivos, em que as necessidades sexuais dos jovens são compreendidas como algo natural, o ascetismo, ou seja, o apego a uma religião, não terá essa natureza defensiva, assim como a busca por um ideal tampouco. Em outras palavras, essas duas defesas são determinadas pelas experiências educacionais e influências sugestivas do ambiente. A experiência interior e a preocupação com problemas filosóficos podem muito bem estar a serviço do autoconhecimento e da descoberta da beleza em suas diferentes manifestações.

Constitui-se ainda mecanismo de defesa a tendência do adolescente à aceitação de um código coletivo de comportamento. Ao viverem segundo as normas de um grupo, os jovens asseguram-se a respeito da adequação de suas formas de conduta, submetidas à dependência do reconhecimento mútuo de similaridade de procedimento. Trata-se de uma proteção contra a angústia, tenha ela a causa que tiver. No meio da "tribo", como se convencionou chamar no Brasil, as diferenças individuais e a espontaneidade emocional são em grande parte ignoradas em prol de uma auto-afirmação, que transmite a falsa idéia de maturidade precoce. Esse recurso defensivo reduz a diferenciação e a individualidade, em prejuízo do idealismo, da dedicação ao conhecimento e do espírito reformador que caracterizam a juventude. Além disso, pode trazer problemas de identidade como conseqüência futura.

Deve-se, no entanto, levar em consideração que as medidas defensivas, em circunstâncias normais, têm caráter transitório e emergencial. São abandonadas logo que se estabelecem as relações amorosas, que auxiliam no progresso decisivo do desenvolvimento emocional. Ao tratar dessa importante etapa da vida que é a adolescência propriamente dita, Blos ${ }^{31}$ esboça uma seqüência hierárquica da evolução psíquica. Segundo ele, o adolescente: 1) começa a considerar-se como igual aos adultos e a julgá-los; 2) começa a pensar no futuro - isto é, em seu trabalho na sociedade; 3) tem a idéia de mudar a sociedade; 4) difere da criança acima de tudo naquilo que pensa além do futuro; 5) compromete-se com possibilidades; 6 ) começa a construir sistemas ou teorias no sentido mais amplo dos termos, e 7) é capaz de analisar seu próprio pensamento.

Com a chegada do final da adolescência, verifica-se a passagem do egocentrismo para a descentralização. Auxilia nesse processo a entrada do

${ }^{31}$ Idem, ibidem, p. 169. 
adolescente no mundo ocupacional. Curiosamente, acompanha esse período o declínio transitório da criatividade, muito provavelmente por causa da intensificação da introspecção. Como contrapartida, a proximidade psicológica com os processos interiores permite ao jovem melhor acesso aos seus sentimentos, o que estimula a sensibilidade e a perceptividade. O fenômeno explica o fato de as produções artísticas dos adolescentes serem, invariavelmente, autobiográficas. Elas representam um esforço para realizar tarefas urgentes de transformações interiores. Não se trata mais perguntar "quem sou eu?", mas, sim, de afirmar "isto sou eu".

\section{Final da adolescência}

O aumento da capacidade de agir intencionalmente, integrar-se socialmente, fazer prognósticos, manter relativa constância emocional e maior estabilidade da auto-estima é o que o indivíduo, em seu desenvolvimento normal, terá conquistado ao final da adolescência. Além disso, estará preparado para unificar os processos relativos ao sentir e ao querer, sujeitar-se à conciliação e ao adiamento, e delinear as preocupações que realmente interessam na vida.

Apesar disso, o declínio da adolescência é momento decisivo, em que o sujeito está vulnerável a crises. Essas podem prejudicar a integração social e resultar em fracassos de adaptação. Não se chega, portanto, a essa fase sem conflitos ou angústias, que são, até certo ponto, favorecedores do desenvolvimento. A passagem para a vida adulta, segundo Blos ${ }^{32}$, é apenas em parte impulsionada pela repressão à bissexualidade que, no entender do psicanalista, nunca é totalmente resolvida em termos de seu desaparecimento. Para ele, entra em jogo no processo de amadurecimento grande variabilidade de adaptações ou soluções individuais, cuja sistematização é tarefa bastante complexa.

O que temos de encontrar é um princípio operacional, um conceito dinâmico, que governe o processo de consolidação do final da adolescência e torne as suas várias formas compreensíveis: primeiro, o mecanismo psíquico que sintetiza os vários processos adolescentes fase-específicos, que os torna estáveis, irreversíveis e Ihes dá um potencial adaptativo; segundo, a fonte dos resíduos específicos dos períodos de desenvolvimento anteriores que sobreviveram às transformações

32 Idem, ibidem, p. 178. 
adolescentes e que continuam a existir sob forma derivada, contribuindo para a formação do caráter. E, finalmente, a fonte da energia que traz para primeiro plano certas soluções e deixa outras em suspenso, emprestando dessa forma ao processo de consolidação uma qualidade decisiva e individual. ${ }^{33}$

Em função de desenvolver tal princípio, Blos ${ }^{34}$ vai buscar no conceito de trauma algumas explicações. Para ele, o trauma é um fenômeno universal da infância. Ao final da adolescência, a conjuntura de ameaça que o originou, ou um componente dela, volta-se novamente para fora. A partir de então, os traumas provocam situações de vida que, de certa maneira, repetem a circunstância original. Esses remanescentes específicos não assimilados do trauma estendem-se pelas diferentes etapas da idade adulta e reclamam expressão contínua. Livrar-se da influência perniciosa do mundo exterior precipitada no trauma é tarefa fundamental para a organização da personalidade, que não termina com a adolescência, mas se configura como trabalho psíquico para toda a existência do ser humano. Visto dessa maneira, o trauma apresenta fatores negativos e positivos. Negativamente, de acordo com a extensão e complexidade do problema, prejudica o desenvolvimento progressivo. Mas, por outro lado, pode exercer pressão incessante no sentido chegar a um acordo com seus resíduos nocivos, propulsando o indivíduo ao amadurecimento contínuo. A tentativa de domínio de um trauma, na maior parte das vezes experimentado como conflito, estimula a auto-estima.

Em suma, espera-se que o jovem, ao final da adolescência, tenha alcançado maior estabilidade e equilíbrio entre ação e emoção, por meio da consolidação da personalidade. Para tanto, evidentemente, condições sócio-educacionais favoráveis são extremamente necessárias.

\section{Pós-adolescência}

Intermediária entre adolescência e vida adulta, a fase da pós-adolescência é vivenciada pelo indivíduo como um importante momento de transição, durante o qual atuam em si aspectos residuais do período anterior ao mesmo tempo em que se the são propostas questões relativas ao amadurecimento. A integração das duas etapas

${ }^{33}$ Idem, ibidem.

${ }^{34}$ Idem, ibidem. 
subjaz ao desempenho das atividades sociais já em pleno curso. A essas alturas, o jovem, se ainda não se casou e teve filhos, pelo menos namora. Se ainda não se fixou em uma profissão, prepara-se para abraçar determinada carreira. Tudo isso faz perder de vista, facilmente, o fato de a formação da personalidade não ter sido completada. Sexualmente, pode sentir-se atraído para a experimentação de várias formas de relacionamento, que vão da simples atração física até o amor idealizado e terno.

A pós-adolescência, portanto, é compreendida como um período essencialmente integrativo. As metas definidas no final da adolescência devem, a partir dessa nova etapa, serem implementadas em termos de relações permanentes. Por conseguinte, a aceitação de papéis sociais definitivos e a escolha de ambientes tornam-se as principais preocupações.

Nesse processo, evidentemente, o indivíduo estará sujeito a fracassos, que ocorrerão sempre que a organização de um "eu" estável não for alcançada. Como conseqüência, a integração de anseios diversos e contraditórios fica impossibilitada. O resultado mais comum nesses casos é o jovem perder-se em um emaranhado de possibilidades de atuação no mundo, como se tentasse manter portas permanentemente abertas a muitas vidas diferentes. Entre as dificuldades a que se encontra vulnerável nessa passagem, Blos ${ }^{35}$ destaca a "fantasia do salvamento".

Em lugar de viver para dominar as tarefas de vida, o adolescente espera que as circunstâncias venham a dominar a tarefa de viver. Em outras palavras, ele espera que a solução do conflito seja minorada, ou totalmente contornada, por um ambiente benévolo. Nesses casos, parece que a dependência original do ambiente, ou seja, a mãe como a eliminadora de tensões e a reguladora da auto-estima, não foi nunca abandonada. A supervalorização dos pais foi transferida para o ambiente que, de acordo com a fantasia, pode proporcionar facilidade e fortuna ao escolhido, se assim desejar.

Nesses casos, há sempre uma total insatisfação com que o mundo circundante pode oferecer. Tal fato leva a um complexo processo de pensamentos, normalmente expressos da seguinte forma: "Se eu tivesse um emprego diferente"; "Se eu fosse casado"; "Se eu pudesse viver na Europa"; "Se eu fosse um pouco

${ }^{35}$ Idem, ibidem, p. 208. 
mais alto, ou mais baixo", e assim por diante. O que todos esses desejos têm em comum é uma qualidade global, uma redução dos intrincados problemas a uma condição única, da qual tudo pode depender. ${ }^{36}$

A resolução do problema está no estabelecimento de um acordo entre os conteúdos psíquicos ainda restantes da ligação do jovem com as figuras parentais introjetadas e aquilo que, de fato, ele esteja buscando para si próprio independentemente das influências paternas. Blos ${ }^{37}$ acredita que o afrouxamento dos laços infantis seja tarefa da adolescência propriamente dita, mas que a revisão definitiva das identificações rejeitadas, provisórias e aceitas com os pais só ocorra, de fato, na pós-adolescência. Em outras palavras, não se atinge a maturidade sem conciliar com a própria individualidade as representações que se tem da imagem do pai ou da mãe.

\subsubsection{Arminda Aberastury}

Segundo Aberastury ${ }^{38}$, psicóloga argentina, a entrada no mundo dos adultos - desejado e temido - significa para o adolescente a perda definitiva de sua condição de criança. Ele não só deve enfrentar o mundo dos adultos como precisa desligar-se de seu mundo infantil. "É o momento crucial na vida do homem e constitui a etapa decisiva de um processo de desprendimento que começou com o nascimento" 39 .

A autora desenvolve a tese de que, durante a fase da adolescência, o indivíduo é impelido a realizar três tipos de luto fundamentais: o luto pelo corpo perdido, o luto pelo papel e pela identidade infantis e o luto pelos pais da infância. A esses, soma-se o luto pela bissexualidade infantil perdida, que acompanha simultaneamente os três processos.

Com relação ao primeiro, explica Aberastury ${ }^{40}$, as transformações ocorridas no corpo, constituintes da base biológica da adolescência, não raramente são sentidas pelo indivíduo como algo externo, frente ao qual ele se encontra como

${ }^{36}$ Idem, ibidem.

${ }^{37}$ Idem, ibidem, p. 210.

${ }^{38}$ ABERASTURY, Arminda. "O adolescente e a liberdade". In: ABERASTURY, Arminda e KNOBEL, Mauricio. Adolescência normal: um enfoque psicanalítico. Trad. Suzana Maria Garagoray. Porto Alegre, Artes Médicas, 1981, p.13.

${ }^{39}$ Idem, ibidem.

${ }^{40}$ Idem, ibidem, pp. 13-23. 
espectador impotente do que ocorre no próprio organismo. Essas mudanças obrigam-no ao desprendimento de seu corpo infantil. O trabalho a ser elaborado é o de encontrar o lugar de si mesmo no corpo transformado e no mundo atual, e, ainda, o de adquirir a capacidade de utilizar seu corpo e seu lugar no mundo.

Referentemente ao papel e à identidade infantis, o adolescente passa a vivenciar situações ante as quais se vê obrigado a uma renúncia da dependência e a uma aceitação de responsabilidades que muitas vezes desconhece. Antes de firmar uma identidade coerente, ele experimenta certa multiplicidade de identificações com elementos de sua cultura contemporânea, que o fará expressar-se por meio de uma combinação instável de vários corpos e identidades, como se representasse de tempos em tempos uma personagem diferente. Isso se dá pela própria incapacidade momentânea de renunciar a determinados aspectos de si mesmo e de utilizar e sintetizar os novos aspectos que vai paulatinamente incorporando na sua relação com o mundo adulto.

No que concerne ao terceiro luto, o jovem tenta de maneira persistente reter na sua personalidade o papel desempenhado pelos pais, procurando constantemente o refúgio e a proteção que eles representam. Dessa forma, é comum aos adolescentes apresentarem flutuações de comportamento extremadamente polares entre dependência e independência, entre refúgio na fantasia e ânsia de crescimento, entre conquistas adultas e refúgios em conquistas infantis. A resolução dessas alternâncias inicia-se pelo progressivo desprendimento das figuras paternas, tarefa que se torna tanto mais complicada quanto mais os pais relutarem em aceitar o fato de estarem envelhecendo e o de seus filhos já não serem mais crianças.

A necessidade de elaborar esses lutos faz com que o adolescente recorra transitoriamente a formas psicopáticas de atuação, que caracterizam sua conduta. Ao fugir do mundo exterior e buscar refúgio no mundo interno, ele provoca o aumento paralelo de sua onipotência narcisista e da sensação de prescindir das situações externas.

Sua hostilidade frente aos pais e ao mundo em geral se manifesta na sua desconfiança, na idéia de não ser compreendido, na sua rejeição da realidade, situações que podem ser ratificadas ou não pela própria realidade. 
Todo esse processo exige um lento desenvolvimento no qual são negados e afirmados seus princípios, lutando entre a necessidade de independência e a sua nostalgia de reafirmação e dependência.

Sofre crises de suscetibilidades e de ciúmes, exige e precisa vigilância e dependência, mas sem transição surge nele uma rejeição ao contato com os pais e a necessidade de independência e de fugir deles. ${ }^{41}$

Se os pais demoram em compreender as oscilações comportamentais dos filhos, dificulta-se o trabalho de luto, durante o qual são necessários permanentes ensaios e provas de perda e recuperação de ambas as idades: a infantil e a adulta. Isso, entretanto, não indica necessariamente que o adolescente apresente tendências a desenvolver algum tipo de psicopatia em seu processo de amadurecimento. O que pode ocorrer é o retarde da criação de uma base de lançamento a partir da qual ele poderá encetar conexões com novos objetos do mundo externo e preparar suas formas de atuação.

Ao incluir-se no mundo com um corpo já maduro, a imagem que o adolescente formou de seu corpo mudou a sua identidade. Ele precisa, então, adquirir uma ideologia que Ihe permita adaptar-se às situações que o circundam ou que the propicie desempenhar ações efetivas no sentido de modificar as circunstâncias. A necessidade de planejar a sua vida, de controlar as mudanças e de adaptar o mundo externo às suas imperiosas aspirações explica seus desejos de reformas sociais.

Dessa forma, para que o adolescente ingresse de maneira plena no mundo adulto, é necessário que a maturidade biológica venha acompanhada da maturidade afetiva e intelectual. Somente assim o jovem terá adquirido um sistema de valores que Ihe servirá para confrontar-se com seu meio de maneira crítica e construtiva, especialmente diante de situações que por ventura rejeite. Portanto, no entender de Aberastury, ele apenas será adulto quando sua posição nos campos social, político, religioso e estético não estiverem mais atreladas à exigência de submeter-se nem à necessidade de submeter.

${ }^{41}$ Idem, ibidem, p. 18. 


\subsubsection{Maurício Knobel}

Discutir os problemas básicos fundamentais relacionados com os processos evolutivos do adolescente, independentemente das circunstâncias exteriores, é o objetivo de Knobel ${ }^{42}$, ao abordar aquilo que ele chama de "síndrome da adolescência normal". Isso não quer dizer, entretanto, que o psicólogo ignore os fatores sócio-culturais na determinação da fenomenologia expressiva dessa etapa da vida. Ele justifica o posicionamento:

Não há dúvidas de que o elemento sócio-cultural influi com um determinismo específico nas manifestações da adolescência, mas também temos que considerar que atrás dessa expressão sócio-cultural existe um embasamento psicobiológico que lhe dá características universais. ${ }^{43}$

Antes ainda de descrever as características da adolescência, naquilo que ela apresenta de bagagem biológica individualizante, Knobel ${ }^{44}$ esclarece que, no papel de pesquisador, sua aproximação do mundo adolescente localizou-se em um aqui e agora do tempo presente das pesquisas realizadas. Por essa razão, ele reconhece que, em termos de ideologia científica, possam existir eventuais preconceitos na definição do marco referencial teórico utilizado no processo de investigação. Lembrando-se que esses estudos foram publicados inicialmente em 1970, na Argentina, discorre-se sobre o pensamento do autor.

Segundo Knobel ${ }^{45}$ integraria a síndrome normal da adolescência a seguinte lista de sintomas: 1) busca de si mesmo e da identidade; 2) tendência grupal; 3) necessidade de intelectualizar e fantasiar; 4) crises religiosas, que podem ir desde o ateísmo mais intransigente até o misticismo mais fervoroso; 5) deslocalização temporal, em situações que o pensamento adquire as características de pensamento primário; 6) evolução sexual manifesta, que vai do auto-erotismo até a heterossexualidade genital adulta; 7) atitude social reivindicatória com tendências anti ou associais de diversa intensidade; 8) contradições sucessivas em todas as

${ }^{42}$ KNOBEL, Mauricio. "A síndrome da adolescência normal". In: ABERASTURY, Arminda e KNOBEL, Mauricio. Adolescência normal: um enfoque psicanalítico. Trad. Suzana Maria Garagoray. Porto Alegre, Artes Médicas, 1981, pp. 24-59.

${ }^{43}$ Idem, ibidem, p. 25.

${ }^{44}$ Idem, ibidem.

${ }^{45}$ Idem, ibidem, p. 29. 
manifestações da conduta, dominada pela ação, que constitui a forma de expressão conceitual mais típica deste período da vida; 9) separação progressiva dos pais; 10) constantes flutuações do humor e do estado de ânimo.

Ainda que de maneira sintetizada, vale apresentar o modo como o psicólogo descreve a manifestação de cada sintoma.

\section{Busca de si mesmo e da identidade}

A infância e a adolescência, no entender de Knobel, não devem ser compreendidas apenas como etapas preparatórias para a maturidade do indivíduo, mas sim como momentos específicos do desenvolvimento de cada ser humano. "A idéia do si mesmo, ou do self, implica [...] o conhecimento da individualidade biológica e social do ser psicofísico em seu mundo circundante, que tem características especiais em cada idade evolutiva" ${ }^{46}$.

As mudanças de tamanho, peso e proporção do corpo que ocorrem nesse período da vida são vivenciadas pelo adolescente como intrusões que desestabilizam o equilíbrio conquistado na infância. Dessa forma, ele vê-se obrigado a buscar reestruturações permanentes externas e internas. Como conseqüência, oscila psiquicamente entre refugiar-se de modo aferrado em seu passado e projetarse intensamente no futuro. Em outras palavras, recusa-se a aceitar a perda de sua condição infantil e, ao mesmo tempo, anseia por assumir responsabilidades no mundo adulto.

É a partir do aperfeiçoamento da estrutura do superego e do enriquecimento do ego, proporcionados pela qualidade das figuras parentais internalizadas que, paulatinamente, o jovem pode iniciar seu processo de individualização e empreender a angustiante tarefa de estabelecer uma identidade adulta. Desse momento em diante, a presença externa dos pais começa a ser cada vez mais desnecessária.

\section{Tendência grupal}

Em oposição às figuras parentais e como forma ativa de determinar uma identidade diferente da do meio familiar, manifesta-se no adolescente o fenômeno

${ }^{46}$ Idem, ibidem, p. 30. 
de comportamento grupal. No meio do grupo, ele encontra reforço necessário para os aspectos mutáveis do ego que se produzem nessa etapa da vida. A turma, a gangue, a tribo assumem importância fundamental, uma vez que o sentimento de dependência, que antes se mantinha atrelado à estrutura familiar, passa a ser transferido para a roda de amigos e colegas. "O grupo constitui assim a transição necessária no mundo externo para alcançar a individualização adulta" 47 .

\section{Necessidade de intelectualizar e fantasiar}

A renúncia ao corpo, ao papel e aos pais da infância, assim como à bissexualidade característica da infância, obriga o adolescente a buscar mecanismos de defesa e compensação. A maneira que encontra de enfrentar situações dolorosas decorrentes dessas perdas reside no pensamento. Por meio da intelectualização, voltada para a reflexão a respeito de princípios éticos, filosóficos e sociais, constrói fantasias conscientes sobre as reformas que gostaria de empreender no ambiente externo. É o momento em que, na mente dos jovens, surgem as grandes idéias de mudar o mundo e salvar a humanidade. Muitos adolescentes, nessa fase, passam a escrever versos, contos, novelas, confissões íntimas ou mesmo a se interessar por qualquer outro tipo de atividade artística.

\section{Crises religiosas}

A busca do ego por identificações positivas é um processo às vezes tão angustiante, que pode fazer com que o jovem se aproxime de crenças religiosas. Porém, dada a natureza mutável e flutuante de seu mundo interno, não é incomum que salte com certa facilidade de um tipo de religiosidade a outro ou mesmo que passe por períodos de profundo misticismo alternados por outros de ateísmo absoluto.

As crises religiosas configuram-se como tentativas de elaboração das perdas características dessa faixa etária. O adolescente de certo modo reconhece que é preciso começar a enfrentar a separação definitiva dos pais e até mesmo aceitar a possível morte deles. Daí a necessidade que sente de se identificar projetivamente

${ }^{47}$ Idem, ibidem, p. 37. 
com imagens muito idealizadas, como forma de garantir a continuidade da existência de si mesmo e de seus pais infantis.

\section{Deslocalização temporal}

A questão do tempo para o adolescente é algo bastante complexo. Ele tanto pode deixar-se levar por urgências injustificáveis quanto postergar atitudes de forma aparentemente irracional. Esse tipo de conduta é interpretado como tentativa de manejar o tempo, negando sua passagem, com o objetivo inconsciente de conservar a infância dentro de si. Conseqüentemente, manifesta-se o sentimento de solidão tão típico desse período da vida, que pode ser externamente observado pelo modo como o adolescente isola-se e retrai-se do convívio social.

Esses momentos de reclusão são compreendidos como uma espécie de suspensão do tempo passado, do futuro e do presente, de modo a poder transformálos em objetos manejáveis. A importância dessas experiências de solidão vivenciadas durante a adolescência, muitas vezes de forma angustiante, será percebida no futuro quando o indivíduo perceber em si que desenvolveu a verdadeira capacidade de estar só. Knobel ${ }^{48}$ considera que a busca do adolescente por uma identidade adulta esteja estreitamente vinculada com a sua capacidade de conceituar o tempo. "Quando este [o adolescente] pode reconhecer um passado e formular projetos de futuro com capacidade de espera e elaboração no presente, supera grande parte da problemática da adolescência" ${ }^{49}$.

\section{A evolução sexual desde o auto-erotismo até a heterossexualidade}

As mudanças biológicas da puberdade são as que impõem a maturidade sexual ao indivíduo. Knobel ${ }^{50}$ cita Spiegel ${ }^{51}$ para explicar que a sexualidade é vivida pelo adolescente como uma força que se impõe em seu corpo, como algo que irrompe sobre o indivíduo ao invés de ser vivido por este como uma expressão de si mesmo. Dessa forma, durante o desenvolvimento de um processo que vai do auto-

${ }^{48}$ Idem, ibidem, p. 44.

${ }^{49}$ Idem, ibidem, p. 44.

${ }^{50}$ Idem, ibidem, p. 48.

${ }^{51}$ SPIEGEL, L. A. "Identity and adolescence". In: LORAND y SCHNEER (comps.). Adolescence. Nova lorque, Paul Hoeber, Inc., 1961. 
erotismo à heterossexualidade, o adolescente oscila permanentemente entre a masturbação e o contato genital com o outro, contato esse que, inicialmente, apresenta um caráter mais exploratório e preparatório do que propriamente de genitalidade procriativa. A partir dessas experiências preliminares, e à medida que vai aceitando a própria genitalidade, o jovem passa a buscar de forma tímida, mas intensa, o parceiro mais apropriado. Começam então os contatos superficiais, os carinhos, que, aos poucos, vão-se tornando cada vez mais íntimos e profundos.

\section{Atitude social reivindicatória}

Ao falar das formas como os jovens reivindicam seus espaços no mundo adulto, Knobel retoma sua discussão inicial sobre a influência do meio sócio-cultural na situação conflitiva típica da adolescência, apontando a família como a primeira expressão da sociedade a influir na conduta dos adolescentes. Durante o processo de separação entre pais e filhos nessa etapa da vida, os primeiros apresentam a mesma situação de ambivalência que os segundos. Isto é, se por um lado os genitores anseiam pela independência dos filhos, de modo a sentirem-se livres de determinadas obrigações, por outro, o crescimento deles pode ser vivenciado de modo atemorizador e angustiante, em decorrência de ciúmes e de situações conflitivas ante a perspectiva do envelhecimento.

Além das primeiras identificações que os adolescentes fazem com as figuras parentais, o meio no qual eles vivem determina inúmeras outras possibilidades de identificação. Tanto na família, como no meio adulto em geral, a adolescência não raramente é recebida de maneira hostil, em virtude dos conflitos que pode causar. É comum a sociedade criar estereótipos por meio dos quais tenta definir, caracterizar e assinalar o adolescente, numa atitude claramente de fobia ante sua presença, compreendida como ameaçadora do lugar social conquistado pelos mais velhos. Como uma espécie de reação a esse posicionamento defensivo, os jovens, com sua energia vital, com sua capacidade de ação, com sua força de reestruturação, tentam modificar a sociedade e assustam os adultos. Observa Knobel ${ }^{52}$ :

${ }^{52}$ KNOBEL, Mauricio. "A síndrome da adolescência normal". In: ABERASTURY, Arminda e KNOBEL, Mauricio. Adolescência normal: um enfoque psicanalítico. Trad. Suzana Maria Garagoray. Porto Alegre, Artes Médicas, 1981, p. 52. 
Não é uma simples causalidade que a entrada na puberdade seja tão destacada em quase todas as culturas. Os chamados ritos de iniciação são muito diversos, mas têm fundamentalmente sempre a mesma base: a rivalidade que os pais do mesmo sexo sentem ao ter que aceitar como iguais - e posteriormente inclusive admitir a possibilidade de serem substituídos pelos mesmos - a seus filhos, que assim se identificam com eles.

Em síntese, o autor acredita que a atitude social reivindicatória dos jovens possa ser considerada uma represália ao comportamento de certo modo castrador dos adultos, conforme ainda se depreende do seguinte trecho:

Nossa própria sociedade pode ser tão cruel como a menos civilizada das culturas arcaicas que conhecemos. É muito conhecida a rigidez de alguns pais, as formalidades que exigem da conduta de seus filhos adolescentes, as limitações brutais que costumam impor, a ocultação maliciosa que fazem do aparecimento da sexualidade, o tabu da menarca, as negações de tipo moralista que contribuem para reforçar as ansiedades paranóicas dos adolescentes. ${ }^{53}$

Cabe, neste ponto, um parêntese no pensamento de Knobel. Como visto anteriormente, as idéias do autor foram desenvolvidas no início da década de 1970, o que leva a inferir que sua visão esteja relacionada com os grandes movimentos reformadores da cultura ocorridos nos anos de 1960. Como se sabe, de lá para cá, a sociedade passou por profundas transformações, especialmente no que se refere ao relacionamento entre pais e filhos. O extremo rigor até então verificado no convívio entre os entes da família parece ter dado lugar, nos dias atuais, ao excesso de indulgências. Atesta essa idéia depoimento de Sayão ${ }^{54}$ :

O mundo tem tornado cada vez mais complexo o relacionamento dos pais com os filhos adolescentes e, consequentemente, com a educação deles. No período pelo qual passamos, em que o início e o fim da adolescência não são mais facilmente identificados, os pais ficaram sem referências sólidas sobre essa passagem para a vida adulta.

${ }^{53}$ Idem, ibidem, p. 53.

${ }^{54}$ SAYÃ̃, Rosely. "A responsabilidade dos pais". Folha de S. Paulo, São Paulo, 7 dez. 2006. "Folha Equilíbrio", p.12. 
Paralelamente, temos outro fenômeno que diz respeito aos adultos. Devido ao nosso contexto cultural, cada vez mais os adultos focam sua vida nos próprios interesses e menos na tarefa de educar os filhos.

$[\ldots]$

$\mathrm{Na}$ verdade, [...] os adultos não querem ocupar o difícil lugar de vetar aos mais novos aquilo de que eles ainda não podem participar.

Conseqüentemente, observa-se no começo deste século XXI que os jovens deixaram de lado o comportamento de revolta e rebeldia. Isto é, parecem estar indiferentes e passivos ante os valores corroídos do mundo atual. Como se não quisessem mudar nada, procuram apenas formas de sobrevivência em meio a uma sociedade na qual injustiça social, corrupção e violência tornaram-se fatos banais. Os pais extremamente repressivos das décadas de 1960 e 1970 geraram filhos que se tornaram pais exageradamente indulgentes. Constata-se, portanto, que o excesso de permissividade não provoca reações reivindicatórias, ao contrário, resulta em inércia. Tirou-se dos jovens a oportunidade de se rebelarem e, como conseqüência, de reestruturarem as relações sociais e recriarem o mundo ideologicamente. O que se vê são adolescentes apáticos. Daí a importância já mencionada da literatura.

\section{Contradições sucessivas em todas as manifestações da conduta}

A ação é forma de conduta essencial dos adolescentes. Constitui-se no modo típico de expressão desse momento da vida. Até o pensamento precisa tornar-se ação para poder ser controlado. Como resultado desse tipo de comportamento, eles estabelecem identidades ocasionais, transitórias, circunstanciais, próprias da idade. Não há nada de anormal na instabilidade permanente dos jovens. Os adultos é que, muitas vezes, demonstram-se incapazes de compreendê-la e aceitá-la.

\section{Separação progressiva dos pais}

A tarefa de busca por uma identidade é acompanhada pela necessidade do adolescente de ir separando-se dos pais, o que não significa necessariamente o 
afastamento físico. Conforme explica Knobel ${ }^{55}$, o "aparecimento da capacidade executora da genitalidade impõe a separação dos pais e reativa os aspectos genitais que tinham começado com a fase genital prévia".

Esse processo de paulatina separação também provoca reações nos pais, cuja qualidade dependerá do grau de desenvolvimento psíquico desses. Em geral a situação provoca ciúmes de ambas as partes. A evolução da sexualidade do adolescente depende, em grande parte, da maneira como os próprios pais aceitam os conflitos e o desprendimento que os filhos, de uma forma ou de outra, podem expressar.

Na visão do psicólogo, muitas vezes, os pais negam o crescimento dos filhos e os filhos vêem os pais com as características persecutórias mais acentuadas. Porém, como já foi lembrado, Knobel realizou seus estudos sobre a adolescência em um momento da vida social em que as relações parentais ainda eram permeadas por muitos tabus sexuais. Sob esse aspecto, os adolescentes dos anos 2000 não sentem mais a necessidade de afastarem-se dos pais para exercerem livremente a sexualidade. É bastante comum hoje em dia casais permitirem que seus filhos durmam na própria casa com seus respectivos parceiros. Os motivos para esse tipo de atitude são vários, entre eles está a alegada necessidade de exercer melhor controle sobre com quem os filhos se relacionam, em uma época em que os índices de violência social atingiram números muito preocupantes.

Constantes flutuações do humor e do estado de ânimo

Mudanças de humor são típicas da adolescência, como decorrência da necessidade de elaboração de lutos que caracteriza essa fase do desenvolvimento. Depressão e ansiedade são sentimentos que acompanham permanentemente o adolescente. Isso se dá pela alternância dos mecanismos empregados de introjeção e projeção na busca da identidade. Se, por um lado, a perda de objetos do mundo infantil pode fazer o jovem submergir na mais profunda desesperança, por outro, a superação dos lutos faz com que se projete no mundo externo de forma presunçosa. A intensidade e a freqüência dessas oscilações são responsáveis pelas rápidas

${ }^{55}$ KNOBEL, Mauricio. "A síndrome da adolescência normal". In: ABERASTURY, Arminda e KNOBEL, Mauricio. Adolescência normal: um enfoque psicanalítico. Trad. Suzana Maria Garagoray. Porto Alegre, Artes Médicas, 1981, p. 56. 
mudanças no seu estado de ânimo. O equilíbrio só virá com a conquista da maturidade.

\subsubsection{Contardo Calligaris}

Tomando de empréstimo a Erikson ${ }^{56}$ o conceito de moratória, Calligaris ${ }^{57}$ define o adolescente como alguém que já percebeu, pelo menos teoricamente, os campos em que um indivíduo se deve destacar para obter reconhecimento da comunidade dos adultos, quais sejam: o das relações amorosas / sexuais e o da potência produtiva, financeira e social; mas que se encontra temporariamente impedido de colocar-se à prova para essas conquistas. Isso ocorre não porque seu corpo não esteja pronto ou porque não tenha capacidade intelectual para desempenhar tarefas importantes no mundo do trabalho, mas porque a própria sociedade barra seu desenvolvimento, alegando que ainda não é o momento de assumir certas responsabilidades.

Por meio dos pais, da escola e da mídia, o adolescente compreende que será tanto mais valorizado na sociedade quanto mais independente e autônomo se tornar. Concomitantemente, porém, entende que, embora esteja em condições de comprometer-se com papéis sociais definidos, terá de esperar ainda por cerca de dez anos para liberar-se da tutela dos adultos. Como conseqüência, manifesta sentimentos e padrões de comportamento reativos, de modo a rebelar-se ante uma impedição que, apesar de temporária, ele vivencia como dolorosa e injusta.

$\mathrm{Na}$ atualidade, soma-se a essa causa de sofrimento o fato de a cultura contemporânea idealizar a adolescência como uma época particularmente feliz na vida dos seres humanos. Impõe-se assim um verdadeiro paradoxo ao adolescente: de um lado, a frustração pelo retardamento da entrada na vida adulta e, de outro, a pressão social para que seja feliz. Além disso, há também a incerteza a respeito do tempo de duração desse período. Em virtude das consideráveis transformações trazidas pela puberdade, tanto fisiológicas quanto psicologicas, sabe-se determinar

${ }^{56}$ Segundo o psicanalista alemão, a "mente adolescente é essencialmente uma mente em moratória, um estágio psicossocial entre a infância e a maturidade, e entre a moralidade aprendida pela criança e a ética a ser desenvolvida pelo adulto". ERIKSON, Erik H. Childhood and Society. New York / London, W.W. Norton \& Company, 1993, pp. 262-3.

${ }^{57}$ CALLIGARIS, Contardo. A adolescência. São Paulo, Publifolha, 2000, pp. 14-5. 
com facilidade o começo da adolescência. O término, no entanto, é absolutamente impreciso, conforme comenta Calligaris ${ }^{58}$ :

O equivalente da adolescência, em outras culturas, é um rito de iniciação, eventualmente acompanhado de algumas provas [...].

$[\ldots]$

Como ninguém sabe direito o que é um homem ou uma mulher, ninguém sabe também o que é preciso para que um adolescente se torne adulto. $\mathrm{O}$ critério simples da maturação física é descartado. Falta uma lista estabelecida de provas rituais.

A expectativa e a incerteza têm como resultados a imaturidade e a insegurança, que fazem o adolescente depender do olhar do outro para construir uma imagem de si próprio. Dito de outro modo, ele está sempre à espreita, na tentativa de saber o que os adultos pensam e esperam dele para que o admitam como par na sociedade. Em decorrência, o jovem torna-se ótimo intérprete e, às vezes, até mesmo realizador dos desejos reprimidos dos mais velhos. Esse fato, ao invés de acarretar aprovação, como seria de se esperar, gera o famigerado conflito de gerações. Isso ocorre porque os ideais recalcados pelos adultos são, em geral, conteúdos que eles gostariam de esquecer definitivamente, de tal modo que, ao vêlos reproduzidos pelo adolescente, apresentam a tendência de reprimi-los novamente, voltando-se contra as atitudes do mais jovem. Um exemplo de conteúdo psíquico reprimido por gerações anteriores, e que retornou por meio do comportamento dos adultos contemporâneos, é comentado por Calligaris ${ }^{59}$ :

Um caso simples e crucial: a idealização do que está fora da lei é própria à cultura moderna. $O$ individualismo de nossa cultura preza acima de tudo a autonomia e a independência de cada sujeito. Por outro lado, a convivência social pede que se traguem doses cavalares de conformismo. Para compensar essa exigência, a idealização do fora-da-lei, do bandido, tornou-se parte integrante da cultura popular.

${ }^{58}$ Idem, ibidem, p. 17.

${ }^{59}$ Idem, ibidem, p. 27. 
A situação descrita pelo psicanalista é facilmente ilustrada por pesquisa do Ibope Opinião ${ }^{60}$, realizada em março de 2006 , cujos resultados revelam que $69 \%$ dos brasileiros já transgrediram alguma lei ou descumpriram alguma regra contratual, para obter benefícios materiais, de forma consciente e intencional. Além disso, $75 \%$ dos entrevistados admitiram que, caso ocupassem cargos públicos, seriam capazes de cometer algum tipo de irregularidade. A respeito desses dados, comenta Sayão ${ }^{61}$ :

[...] as relações sociais, que têm estado agressivas e violentas, têm servido de justificativa para muitos pais restringirem o âmbito de circulação de seus filhos. Já comentei que [...] crianças e jovens não andam mais pelas ruas das cidades. Pois agora, com os dados dessa pesquisa, fica mais difícil localizarmos essa violência nos outros, nesses estranhos. Ela está em nossas atitudes também.

A partir do exposto, subentende-se que o estado de rebeldia característico da adolescência emerge da própria nostalgia adulta de transgressão. Ou seja, o adolescente transgride porque esse é o desejo reprimido dos adultos com quem convive, os quais tiveram de abandonar seus sonhos de individualidade e libertação para acomodar-se às normas da sociedade. No processo educacional, pais e/ou responsáveis transmitem aos mais jovens as regras de adaptação ao meio, de maneira a fazer com que eles aceitem a conformidade social. Por intermédio desse jogo entre inconsciente transgressor e consciente conformista do adulto, instala-se o conflito entre os mais novos e os mais velhos. Isso porque, conforme explica Calligaris ${ }^{62}$, quanto "mais o adulto se constituir como autoridade moral, tanto mais se qualifica como hipócrita, porque a cultura (e ele junto com ela) promove aquele que faz exceção à norma". Nesse contexto, continua o psicanalista ${ }^{63}$, se "o imperativo cultural dominante é 'Desobedece! ', 'Prova tua autonomia', então

${ }^{60}$ PESQUISA revela controvérsias na opinião do eleitor brasileiro sobre corrupção e ética. IBOPE Opinião. São Paulo, 29 mar. 2006. Disponível em: http://www.ibope.com.br/calandraWeb/servlet/CalandraRedirect?temp=6\&proj=PortallBOPE\&pub=T\& $\mathrm{db}=$ caldb\&comp=pesquisa leitura\&nivel=null\&docid=403666AC00F301D783257140004EC317. Acesso em: 9 out. 2007.

${ }^{61}$ SAYÃO, Rosely. "Que cidadania é essa?" Folha de S. Paulo, São Paulo, 6 abr. 2006. "Folha Equilíbrio", p.12.

${ }^{62}$ CALLIGARIS, Contardo. A adolescência. São Paulo, Publifolha, 2000, p. 29.

${ }^{63}$ Idem, ibidem, p. 33. 
desobedecer pode ser uma maneira de obedecer. E obedecer, quem sabe, talvez seja o jeito certo de não se conformar".

A circunstância que se estabelece coloca o adolescente em desespero, ante a difícil tarefa de obter o reconhecimento dos adultos. Para tanto, ele atuará de inúmeras maneiras diferentes, a maioria delas não raramente mal compreendidas pela sociedade como psicopatia. Para explicar essas formas de conduta, Calligaris ${ }^{64}$ cria uma espécie tipologia comportamental da adolescência.

\section{O adolescente gregário}

Devido à moratória que lhe é imposta e desnorteado pela falta de definição dos requisitos para ser aceito como par no mundo dos adultos, os adolescentes afiliam-se a grupos de indivíduos da mesma faixa etária, nos quais se sentem mais adequadamente integrados. Essas associações podem ter como motivação a amizade, a adoção de um determinado estilo de pensar de vestir, de se divertir, ou mesmo se configurar como verdadeiras gangues. Nesses casos extremos, o grupo passa a ser visto como perigoso pela sociedade, dado seu poder de influir na desagregação familiar e desestabilizar a hierarquia entre as gerações.

\section{O adolescente delinqüente}

Por serem portadores dos sonhos reprimidos dos adultos, os adolescentes esperam obter o reconhecimento e o amor dos mais velhos. Porém, em geral, não é isso que ocorre. Os adultos tomam as atitudes dos jovens como preocupantes. $\mathrm{Na}$ dúvida sobre como agir, oscilam entre a tolerância e a repressão. Segundo Calligaris ${ }^{65}$, tolerar não é uma opção, pois os jovens atuam mesmo no sentido de provocarem a repressão. Caso não sejam reprimidos, agirão com mais violência.

A repressão, porém, também pode causar problemas. Se tiver um caráter preventivo, representará uma afirmação da não-maturidade dos adolescentes. Se for punitiva, sinalizará para eles que seus gestos não foram aceitos como deveriam, ou

\footnotetext{
${ }_{65}^{64}$ Idem, ibidem, pp. 35-57.

${ }^{65}$ Idem, ibidem, p. 42.
} 
seja, como a realização de um ideal recalcado dos mais velhos. Em ambos os casos, a reação será de intensificação da rebeldia, como explica o psicólogo ${ }^{66}$ :

[...] Na relação com os adultos (não só sua família), o adolescente, não conseguindo produzir respeito, prefere e consegue produzir medo. $\mathrm{O}$ medo é o equivalente físico, real, do que o respeito seria simbolicamente.

\section{O adolescente toxicômano}

O uso de drogas, além de ser prejudicial à saúde e poder até mesmo levar à morte, retira do indivíduo aquilo no qual se baseia a continuidade e a riqueza material da sociedade, que é o desejo. Os sistemas econômicos do mundo contemporâneo baseiam-se na permanência da insatisfação humana. Daí o fato de as drogas serem tão fortemente combatidas.

Os insistentes argumentos sobre os perigos das drogas tendem a produzir efeito contrário ao esperado, pois representam para os adolescentes uma proteção pela qual eles não pedem e que, ainda por cima, os infantiliza.

\section{O adolescente que se enfeia}

Com o objetivo de desafiar os padrões estéticos dos adultos, ou mesmo para identificarem-se com o grupo do qual participam, os adolescentes muitas vezes enfeiam-se. Além disso, o ato de produzir um visual de todo excêntrico, para dizer o mínimo, pode corresponder tanto a uma recusa da sexualidade quanto seu contrário, ou seja, certo exibicionismo erótico fora dos padrões convencionais.

\section{O adolescente barulhento}

As músicas, as "baladas", os videoclipes que produzem o entretenimento dos adolescentes desempenham função importante para o período de passagem que representa a adolescência. Enquanto cantam e dançam, os jovens incorporam personagens e constroem enredos fictícios, quase sempre baseados em figuras da mídia com as quais buscam se identificar transitoriamente. A fruição de bens da

\footnotetext{
${ }^{66}$ Idem, ibidem, p. 44.
} 
indústria cultural e do universo midiático permite a adoção de um estilo, de um padrão comportamental que possa ser momentaneamente aceito, sem a necessidade de se comprometer definitivamente com ele. Essa maneira de atuar, não raramente, é observada também entre os adultos.

\subsection{Maturidade}

Além dos estudos relacionados com o desenvolvimento psíquico durante a adolescência, buscou-se descrever o resultado de pesquisas sobre o processo de evolução psicológica na idade adulta. Serviu de guia para o contato com os principais pensadores sobre o assunto levantamento realizado por Staude ${ }^{67}$. A partir de texto do professor da Universidade de Santa Clara e diretor do Proteus Institute, na Califórnia, EUA, foram consultadas obras dos mais destacados estudiosos, conforme se apresenta a seguir.

\subsubsection{John-Raphael Staude}

Como já foi dito, estudos sobre a maturidade são escassos. Ao interessar-se pelo assunto, Staude ${ }^{68}$ combinou o conhecimento da teoria e dos métodos do desenvolvimento do ciclo vital com o treinamento em sociologia comparativa e história social e cultural européia. Para Staude, a compreensão do desenvolvimento da personalidade e da produtividade ao longo de toda a vida só se torna possível por meio de uma abordagem biográfica, histórica, sociológica e psicológica. Tendo como objetivo avaliar as contribuições de Jung para a psicologia da evolução da personalidade adulta, o professor, antecipadamente, faz um breve levantamento sobre as idéias dos principais estudiosos que se dedicaram a compreender a maturidade humana. Conforme ele mesmo explica, o rigoroso estudo do desenvolvimento adulto normal na psicologia americana foi iniciado no começo do século XX por G. Stanley Hall, cujo livro Adolescence, publicado em 1904, permaneceu como um clássico durante vários anos. Só muito posteriormente é que os psicólogos voltaram a se debruçar sobre o tema.

${ }^{67}$ STAUDE John-Raphael. O desenvolvimento adulto de C. G. Jung. Trad. Humberto Arcanjo Brito Rodrigues e Sílvia Helena Azarite Vianna. São Paulo, Cultrix, 1995, pp. 8-47.

${ }^{68}$ Idem, ibidem. 


\begin{abstract}
As bases para uma psicologia do desenvolvimento da personalidade foram estabelecidas na segunda metade no século $X X$ por Carl Gustav Jung, Charlotte Bühler e Fred Massarik (1968), Robert Havinghurst (1948) e Erik Erikson (1950). Ao contrário de muitos outros psicólogos, eles reconheceram que o desenvolvimento humano continua durante o ciclo vital, e argumentaram que a vida de cada pessoa tem uma estrutura básica de desenvolvimento, porque todas as vidas são governadas por princípios de desenvolvimento comuns. Esses pioneiros da psicologia do desenvolvimento tentaram descobrir e analisar as tarefas que todo adulto enfrenta quando passa de uma fase de desenvolvimento para outra durante o ciclo vital. ${ }^{69}$
\end{abstract}

Entre as teorias compiladas por Staube ${ }^{70}$, três delas são resumidamente descritas neste trabalho a partir dos próprios escritos do professor estadunidense, quais sejam: as de Charlotte Bühler e Fred Massarik (que trabalharam juntos), Robert Havinghurst e Nevit Sanford. As idéias de outros dois cientistas citados - Erik Erikson e Daniel Levinson -, dada a importância de suas contribuições para o avanço do conhecimento na área, foram consultadas diretamente em suas obras originais e apresentadas em itens independentes. Com relação aos conceitos de Jung (e de alguns de seus continuadores), esses foram desenvolvidos juntamente com a análise do livro O relógio do mundo, de Lino de Albergaria, objeto de estudo central desta tese.

\title{
Charlotte Bühler, Fred Massarik e a teoria da auto-realização
}

A partir de vários casos clínicos, como também da análise de muitas biografias, Bühler e Massarik convenceram-se de que nos níveis mais profundos da personalidade há um self nuclear voltado ao propósito e ao sentido daquilo que eles chamaram de "autodeterminação". Nesse sentido, aproximaram-se do trabalho de Jung, ao mesmo tempo em que criticavam a psicologia do ego, por acreditarem que o ego pode buscar satisfazer ambições ou falsos valores e ser responsável pelo afastamento do indivíduo de seu verdadeiro self.

${ }_{70}^{69}$ Idem, ibidem, p.27.

${ }^{70}$ Idem, ibidem. 
Robert J. Havinghurst e a teoria da socialização

Entre 1935 e 1950, Havinghurst participou nos EUA de um grupo de pesquisas sobre o desenvolvimento da criança. Como resultado dos trabalhos, surgiu o conceito de "tarefa de desenvolvimento", para designar a necessidade do indivíduo de combinar a consciência do impulso para o crescimento com as exigências, repressões e oportunidades proporcionadas pelo ambiente social família, escola, grupo de amigos e comunidade.

A partir dessa experiência, Havinghurst passou a ministrar cursos de desenvolvimento infantil e de adolescentes na Universidade de Chicago. Em 1948, baseado no desenvolvimento biológico e nas expectativas sociais que mudam durante o curso da vida, publicou obra na qual divide o ciclo vital entre os seguintes períodos: 1) primeira infância - do nascimento até os 5 ou 6 anos; 2) infância intermediária - dos 5 ou 6 anos aos 12 ou 13; 3) adolescência - dos 12 ou 13 anos aos 18 ; 4) idade adulta - dos 18 aos 35 anos; 5) idade adulta intermediária - dos 35 aos 60 anos; 6 ) maturidade - a partir dos 60 anos.

\section{Nevitt Sanford e a teoria holística}

Segundo Sanford, o desenvolvimento da personalidade se dá continuamente, em todas as idades. Ou seja, diferentemente do que preconiza a teoria psicanalítica clássica, o psicólogo não acredita que o padrão do desenvolvimento esteja irremediavelmente na infância. Ao contrário, ele ocorre durante todo o ciclo vital, como resposta aos desafios apresentados pelo ambiente. Sob esse aspecto, modificações no meio externo podem produzir significativas transformações da personalidade. Por essa razão, para se desenvolver com êxito, o indivíduo volta e meia na vida precisa ser auxiliado a encontrar estímulo para mudar o comportamento e adquirir autoconhecimento, como forma de poder integrar as mudanças dentro da personalidade.

\subsubsection{Erik Homburger Erikson}

Erikson nasceu em 1902, na cidade de Frankfurt, Alemanha. A partir de um convite para trabalhar com pacientes submetidos à psicanálise, entrou em contato 
com o grupo de Anna Freud. Em 1933, mudou-se para os Estados Unidos, tornandose o primeiro psicanalista infantil daquele país. A partir de seus estudos sobre a identidade, em 1950, publicou Childhood and Society ${ }^{71}$, que viria a se tornar um dos mais influentes livros do século $X X$ sobre o desenvolvimento da personalidade.

Embora não negasse a teoria freudiana sobre desenvolvimento psicossexual, Erikson mudou o enfoque desta para o problema da identidade e das crises do ego, levando em consideração o contexto sociocultural. Vale notar que vários aspectos da teoria de Sigmund Freud foram modificados por seus discípulos, resultando em algumas dissidências no círculo de estudos do pai da Psicanálise. Entre os avanços do pensamento freudiano que mais repercutiram para o estudo do comportamento humano no século $X X$, registra-se a mudança de foco do id para o ego, como explicam Rabello e Passos ${ }^{72}$ :

Anna Freud, filha de Sigmund Freud, dando continuidade aos seus estudos, atribuiu ao ego uma característica de mais autonomia, com um maior poder de decisão e atuação. Anna também ampliou os mecanismos de defesa de sete para dez, atribuindo a eles um caráter menos patológico do que Freud o fizera. Com sua teoria, Anna Freud também transformou os estágios psicossexuais de seu pai em estágios de busca e domínio do ego, dando a base para os estudos de Erik Erikson.

Estudando o curso de vida de algumas pessoas famosas, Erikson ${ }^{73}$ defendeu a idéia de que o ciclo vital é compreendido como um contínuo de oito fases, cada uma com influência marcante sobre a seguinte. Segundo o psicólogo, o desenvolvimento psicossocial ocorre por meio de "crises", ou seja, de momentos decisivos nos quais são experimentadas fortes pressões para mudanças. Da solução positiva da crise, surge um ego mais rico e mais forte; da solução negativa, tem-se um ego mais fragilizado. Dessa forma, a personalidade vai-se reestruturando de acordo com as experiências vividas, enquanto o ego vai-se adaptando aos sucessos e fracassos. Trata-se, na verdade, de uma série de tarefas que o indivíduo deve desempenhar em diferentes períodos da vida, conforme se descreve a seguir.

${ }^{71}$ ERIKSON, H. Erik. Childhood and Society. 3.ed., New York, W.W. Norton \& Company, Inc., 1993.

${ }^{72}$ RABELLO, Elaine e PASSOS, José Silveira. "Erikson e a teoria psicossocial do desenvolvimento". Portal Brasileiro de Análise Transacional, Rio de Janeiro. Disponível em: http://www.josesilveira.com/artigos/erikson.pdf. Acesso em: 17 set. 2007.

${ }^{73}$ ERIKSON, H. Erik. Childhood and Society. 3.ed., New York, W.W. Norton \& Company, Inc., 1993, pp. 247-69. 


\section{Confiança básica "versus" desconfiança básica}

A primeira relação social do bebê é estabelecida quando ele se torna capaz de compreender que, embora sua mãe - provedora do conforto e da garantia que ele precisa - não esteja diante de seu campo de visão, é possível esperar por ela sem ansiedade ou raiva. Isso porque adquiriu a força básica dessa primeira etapa do desenvolvimento psicossocial que é a esperança, ou seja, ele confia que sua mãe irá voltar. Quando a mãe confirma suas expectativas, gera-se na criança o estado de confiança básica no mundo externo como um lugar bom e acolhedor. Porém, se o cuidado pelo qual se espera demora ou mesmo não chega, o sentimento que surge é o da desconfiança básica. Nesse caso, o mundo é compreendido como hostil.

Mas o estado geral de confiança básica vai além da certeza de poder contar com os cuidados externos, implica também confiar em si mesmo e na capacidade do próprio organismo de lidar com situações de urgência. Daí a importância de a criança aprender a lidar com certas frustrações, como forma de aprender a distinguir entre as esperanças que podem daquelas que não podem ser realizadas. Nesse contexto, ainda que em tenra idade, ela já está dando os primeiros passos para a formação da personalidade.

\section{Autonomia "versus" vergonha e dúvida}

Nesta fase, a criança desenvolveu certo grau de maturação muscular, que a impulsiona para atividades de experimentação por meio das quais possa alcançar a autonomia. Ela aprendeu a ter controle sobre suas necessidades fisiológicas e a cuidar de sua higiene pessoal, o que the permite sentir-se confiante e livre para aventurar-se. No entanto, se for censurada ou ridicularizada, sentirá vergonha e dúvida quanto a sua capacidade de ser autônoma. Dessa forma, sente-se desafiada a encontrar o equilíbrio entre o desejo de explorar todas as possibilidades que o corpo oferece e as restrições ditadas pelas regras sociais.

Nesse jogo entre o que pode e o que não pode ser feito, se a criança é forçada a reprimir demais seus impulsos para ação, isso resulta em prejuízo para o desenvolvimento da autonomia. Se ocorrer o contrário, isto é, se ela não é razoavelmente contida pelos adultos que a cercam, fica exposta a perigosas forças destrutivas. Portanto, o meio ambiente em que ela vive exerce papel fundamental 
para que seja encorajada a encontrar, por si própria, o meio-termo para suas ações. Ao conseguir isso, estará protegida contra a vergonha e a dúvida causada por certas experiências, muitas vezes sem sentido, que Ihe são impostas arbitrariamente pelos adultos.

\section{Iniciativa "versus" culpa}

A confiança e a autonomia desenvolvidas nas fases anteriores serão associadas à iniciativa, propiciada pela escolarização e ampliação do círculo de contatos da criança. A partir de então, ela já é capaz de planejar e realizar determinados objetivos. Esse período é correspondente, na teoria freudiana, àquele em que se dá o Complexo de Édipo. Isso significa que, entre suas metas, incluem-se aquelas voltadas para investigar as diferenças sexuais e os diversos papéis desempenhados por homens e mulheres na cultura em que vive.

No entanto, o que muitas vezes sobrevém é o fato de a criança não conseguir atingir suas metas, seja porque essas estão além de suas possibilidades seja porque não são socialmente aceitas, em especial aquelas relacionadas à sexualidade. Nesses casos, podem surgir dois sintomas: ou uma fuga por meio da fantasia de assumir outras personalidades ou o despertar de um sentimento de culpa, que, em certas circunstâncias, está associado à sensação de fracasso. Em ambos as situações, há uma inibição da iniciativa de explorar novas situações ou de buscar novos conhecimentos.

A iniciativa, contudo, também pode voltar-se para a vontade de aprender, quando a criança manifesta curiosidade intelectual ou mesmo o desejo de desempenhar algum tipo de tarefa. Cabe ao adulto ajudá-la a discernir entre aquilo que está ou não ao seu alcance. Se os pais atuarem adequadamente, o desenvolvimento ocorrerá de modo sadio, como explicam Rabello e Passos ${ }^{74}$ :

Quando a criança se dá conta de que realmente existem coisas que estão fora de suas capacidades (ainda), ela se contenta, não em fantasiar, mas sim em realizar uma espécie de "treino", o que, na verdade, se constitui num teste de personalidade que a criança aplica em si. Para isso, ela utiliza

${ }^{74}$ RABELLO, Elaine e PASSOS, José Silveira. "Erikson e a teoria psicossocial do desenvolvimento". Portal Brasileiro de Análise Transacional, Rio de Janeiro. Disponível em: http://www.josesilveira.com/artigos/erikson.pdf. Acesso em: 17 set. 2007. 
jogos, testando sua capacidade mental, dramatizações, testando várias personalidades nela mesma, e brinquedos, que proporcionam uma realidade intermediária. Tudo isso é o que faz a conexão sadia do mundo interno e externo da criança.

\section{Diligência "versus" inferioridade}

Nesta fase, correlata ao período de latência da teoria freudiana, a criança já vai à escola e já convive em outros ambientes fora do âmbito familiar. Dessa forma, passa a atuar de acordo com o que é valorizado no mundo dos adultos. Ela já não precisa mais chamar atenção pelo subterfúgio de obter cuidados. Aprendeu a conquistar reconhecimento por meio de atividades produtivas. A essas alturas, já descobriu certo sentido de finalidade das ações, levando em consideração o fato de que suas buscas futuras estarão necessariamente fora da família. A partir disso, está pronta para desafiar-se, com vistas a descobrir competências e habilidades que possam levá-la adiante. É quando começa a estabelecer objetivos de vida e a se interessar pelo conhecimento e por ferramentas. Mediante o princípio do trabalho, descobre o prazer de desempenhar uma tarefa com "atenção e perseverante diligência", como diz Erikson ${ }^{75}$.

O perigo que a criança corre nesta etapa está relacionado com certo sentimento de inadequação e inferioridade, que pode surgir em decorrência de falhas provocadas por falta de ajuda ou excesso de exigência, seja dos adultos seja de seus pares. Se ela sentir-se desesperançada com relação aos desafios e instrumentos ou, ainda, que tem menos capacidade do que seus companheiros, pode ser desencorajada a identificar-se com eles. Muitas crianças têm seu desenvolvimento comprometido justamente nesta fase, quando os pais falham em prepará-las para a escola ou mesmo quando a escola falha em oferecer o aprendizado de que elas têm necessidade. É fundamental, portanto, que a sociedade esteja preparada para fazê-las compreender o significado dos papéis sociais no mundo tecnológico e econômico.

${ }^{75}$ ERIKSON, H. Erik. Childhood and Society. 3.ed., New York, W.W. Norton \& Company, Inc., 1993, p. 259. 


\section{Identidade "versus" confusão de papéis}

Neste estágio, não se fala mais em infância, mas sim em puberdade e adolescência. No dizer de Erikson ${ }^{76}$, o adolescente vive um período de moratória, ou seja, ele encontra-se a meio caminho entre a moralidade aprendida quando criança e a ética a ser desenvolvida pelo adulto em formação. Ao explicar a mente do adolescente, continua o psicólogo ${ }^{77}$ :

[...] Essa é uma mente ideológica - e, de fato, é a perspectiva ideológica da sociedade que fala mais alto ao adolescente, que está ansioso para ser aceito por seus pares, e está pronto para ser confirmado pelos rituais, crenças e programas que, ao mesmo tempo, definem o que é nocivo, nefasto e inimigo.

A rapidez com que se dá a transformação do corpo na adolescência só é equivalente àquela verificada na tenra infância. Associa-se a esse processo a maturidade genital, vivenciada como um fato novo. Ambas as circunstâncias fazem com que o jovem se questione sobre quais características dos anos anteriores terão uniformidade e continuidade em si próprio.

Entre as crises de identidade experimentadas nesta fase está o dilema adolescente de comparar o modo como os outros o enxergam com o modo como ele mesmo se percebe. Além disso, ele vê-se diante da difícil tarefa de conciliar as habilidades desenvolvidas na infância com as ocupações relativas à nova fase. Como medida auxiliar para a resolução dos conflitos, tendo em vista salvaguardar uma identidade final, o jovem apresenta a tendência de eleger ídolos e ideais com os quais possa se identificar. A necessidade que o move para essa forma de atuação é a de integrar as vicissitudes da libido com o desenvolvimento das atividades de doação e com as oportunidades oferecidas pelos papéis sociais.

Outro fenômeno característico da adolescência é o da formação de turmas e gangues, no interior das quais as formas de comportamento são estereotipadas. Esses agrupamentos servem não só para que os adolescentes ajudem uns aos outros a passarem pelos desconfortos típicos de uma identidade difusa, como também para que a capacidade de ser fiel de cada membro seja testada.

${ }_{77}^{76}$ Idem, ibidem, pp. 262-3.

${ }^{77}$ Idem, ibidem. 
Paralelamente ao convívio no grupo, pode ocorrer de o jovem vir a se apaixonar. Esse sentimento, em primeira instância, não está relacionado à atração sexual. Para muitos adolescentes, o amor é uma tentativa de obter definição de identidade, por meio da projeção da própria imagem no outro, para que assim possa espelhar-se e reconhecer-se.

O perigo desse estágio é o da confusão de identidade. Como é um momento de dúvidas a respeito da identidade sexual, não raramente alguns jovens apresentam problemas psicóticos que podem desencadear, até mesmo, episódios de delinqüência. Porém, é a inabilidade para desenvolver uma identidade ocupacional que causa maiores distúrbios psíquicos entre os adolescentes. A respeito do assunto, esclarecem Rabello e Passos ${ }^{78}$ :

Toda preocupação do adolescente em encontrar um papel social provoca uma confusão de identidade, afinal, a preocupação com a opinião alheia faz com que o adolescente modifique o tempo todo suas atitudes, remodelando sua personalidade muitas vezes em um período muito curto, seguindo o mesmo ritmo das transformações físicas que acontecem com ele.

Quando ocorre a confusão de identidade, o jovem sente vazio existencial, tornando-se ansioso ou inclinando-se para o isolamento. Pode ainda projetar suas tendências em outras pessoas, como forma de negar a própria identidade. As crises desse período, no entanto, têm seus aspectos positivos, pois representam oportunidades de crescimento emocional e de estabilização da identidade, desde que os conflitos relativos às fases anteriores tenham sido resolvidos a contento.

\section{Intimidade "versus" isolamento}

Após conquistar uma identidade relativamente estável, o indivíduo, que a partir desta fase já é adulto, está ansioso para unir-se com outras pessoas de maneira mais bem estabelecida. Ao desenvolver-se de modo regular nas etapas

${ }^{78}$ RABELLO, Elaine e PASSOS, José Silveira. "Erikson e a teoria psicossocial do desenvolvimento". Portal Brasileiro de Análise Transacional, Rio de Janeiro. Disponível em: http://www.josesilveira.com/artigos/erikson.pdf. Acesso em: 17 set. 2007. 
anteriores, conseguiu a maturidade necessária para fundir sua identidade com a dos parceiros, em diversos setores da vida, sem se sentir amedrontado. Em outros termos, ele adquiriu a capacidade e a força ética para fazer parte de afiliações e envolver-se em relacionamentos, mesmo que isso possa representar significantes sacrifícios e compromissos. Inserem-se nesse contexto o convívio profissional, as amizades íntimas, as atividades inspiradas por líderes, mestre e professores, e, especialmente, as uniões amorosas e as relações sexuais, que muitas vezes exigem do indivíduo o abandono de si próprio.

Existem nessa etapa, portanto, os riscos advindos do receio de perder-se o ego e deixar-se diluir a identidade conquistada. Caso a experiência seja evitada por conta desse medo, o sujeito tenderá a refugiar-se no isolamento e no distanciamento. Nessa circunstância, alguns indivíduos são levados a destruir forças e pessoas que possam tentar invadir sua intimidade e representar algum tipo de ameaça a sua liberdade. Há também a probabilidade de o sujeito, como forma de proteção, buscar refúgio em grupos fechados, elitistas, do qual participam apenas aqueles que transigem na forma de pensar. Na maioria das vezes, a necessidade de encontrar uma equação entre permitir-se a criação de laços de intimidade e isolar-se surge no cotidiano das relações amorosas. Decorre daí a maior parte das dificuldades da vida de casal. Essas, no entanto, podem servir como aprendizado para o desenvolvimento, de acordo com o que pensa Erikson ${ }^{79}$ :

O perigo desse estágio é que aquelas íntimas, competitivas e combativas relações são experimentadas com e contra a mesma pessoa. Mas conforme as áreas do dever adulto são delineadas, e conforme os encontros competitivos e o envolvimento sexual são diferenciados, esses eventualmente tornam-se foco daquele sentido ético que é marca do adulto.

\section{Generatividade "versus” estagnação}

Este é o período da meia idade, em que a crise do indivíduo está relacionada com aquilo que ele gerou, ou ainda pode gerar, desde filhos até idéias e produtos.

${ }^{79}$ ERIKSON, H. Erik. Childhood and Society. 3.ed., New York, W.W. Norton \& Company, Inc., 1993, p. 264. 
Segundo Erikson ${ }^{80}$, o homem maduro "necessita ser necessitado" e a maturidade precisa ser direcionada para a produção e para os cuidados com o que foi produzido. Essa condição é fundamental para que o ser humano não corra o risco de absorver-se em si mesmo, o que representaria a estagnação.

Ao interpretar essa fase do esquema eriksoniano do desenvolvimento psicossocial, Staude ${ }^{81}$ cita o ensino como um bom exemplo de produtividade, isso porque a transmissão de conhecimentos ilustra o modo como as fases da vida se engrenam em todo o ciclo vital, fazendo interagir o adulto, a criança, a cultura. A generatividade, portanto, consiste em auxiliar na formação das próximas gerações. Se o indivíduo não se percebe como deixando algumas sementes de si próprio para o futuro, terá a sensação de que tudo que fez e construiu não valeu a pena. Por outro lado, se deixar-se levar por certa arrogância em virtude de ter mais experiência, pode tornar-se autoritário. Sobre esse período Rabello e Passos ${ }^{82}$ comentam:

Cada vez mais esta fase tem se ampliado. Até algumas décadas atrás, a forma de viver esta fase era casando e criando filho, principalmente para a mulher. Hoje, com uma gama maior de escolhas a serem feitas, as formas de expressar a generatividade também se ampliam, de forma que as principais aquisições desta fase, como dar e receber, criar e manter, podem ser vividas em diversos planos relacionais, não somente na família.

Integridade "versus" desesperança

Se o indivíduo chega à velhice com o sentimento de ter dado o melhor de si nas situações produtivas que vivenciou; se é capaz de adaptar-se tanto aos triunfos conquistados quanto aos desapontamentos acumulados; se está satisfeito com o papel que cumpriu na formação dos mais jovens; se está gratificado com os produtos e as idéias que gerou; se não carrega consigo arrependimentos nem se lamenta sobre as oportunidades perdidas, estará em condições de sentir-se íntegro. Dessa forma, aquele que for possuidor de integridade estará pronto para defender

${ }^{80}$ Idem, ibidem, pp. 266-7

${ }^{81}$ STAUDE John-Raphael. O desenvolvimento adulto de C. G. Jung. Trad. Humberto Arcanjo Brito Rodrigues e Sílvia Helena Azarite Vianna. São Paulo, Cultrix, 1995, p. 33.

${ }^{82}$ RABELLO, Elaine e PASSOS, José Silveira. "Erikson e a teoria psicossocial do desenvolvimento". Portal Brasileiro de Análise Transacional, Rio de Janeiro. Disponível em: http://www.josesilveira.com/artigos/erikson.pdf. Acesso em: 17 set. 2007. 
seu próprio estilo de vida contra os perigos da decadência física e econômica. Do contrário, sobrevirão a nostalgia, a tristeza, a depressão.

\subsubsection{Daniel J. Levinson}

Daniel J. Levinson e seus colaboradores da Universidade de Yale, em Connecticut, nos EUA, são responsáveis por um dos mais abrangentes estudos sobre a maturidade já apresentados. Ainda que a pesquisa tenha se limitado ao universo masculino, serviu de base para a construção de ampla teoria, divulgada em sua forma final por meio do livro The Seasons of a Man's Life. ${ }^{83}$ A respeito do fato de ter deixado as mulheres de fora do universo pesquisado, Levinson ${ }^{84}$ justifica:

Apesar do meu forte desejo de incluir as mulheres, decidi-me finalmente contra a idéia. Um estudo de vinte homens e vinte mulheres não faria justiça a nenhum dos grupos. As diferenças entre mulheres e homens são tão suficientemente grandes que teriam de se tornar o principal foco das análises.

A partir dessa decisão, entre 1968 e 1970, a equipe de Levinson entrevistou quarenta homens entre 35 e 45 anos, distribuídos entre quatro tipos de ocupação profissional, dez de cada uma delas: operários industriais horistas, executivos, professores universitários da área de Biologia e escritores. Ao método de abordagem dos indivíduos selecionados para a amostragem, foi dado o nome de "entrevista biográfica" ${ }^{85}$. O objetivo principal do grupo de pesquisadores foi o de criar uma perspectiva desenvolvimentista da maturidade do homem, tomando inicialmente por base os estudos tradicionais de Freud, Jung e Erikson, conforme explica Levinson ${ }^{86}$.

A mais promissora visão sobre o ciclo vital, e sobre o desenvolvimento adulto, veio do campo internacionalmente conhecido como "psicologia profunda", fundada por Sigmund Freud (1856 - 1939). [...] Freud, porém, estava mais inclinado primariamente a considerar a

\footnotetext{
${ }^{83}$ LEVINSON, J. Daniel et alii. The Seasons of a Man's Life. New York, Ballantine Books, 1978.

${ }^{84}$ Idem, ibidem, p. 9.

${ }^{85}$ Idem, ibidem, p.14.

${ }^{86}$ Idem, ibidem, p. 4.
} 
maturidade como um cenário em que os conflitos inconscientes infantis fossem reordenados do que propriamente um período de ulterior desenvolvimento.

Em nosso ponto de vista, aquele que pode justificadamente ser considerado o pai dos modernos estudos sobre o desenvolvimento adulto é Carl. G. Jung (1875 - 1961). Durante a maior parte dos seus trinta anos, Jung foi discípulo de Freud e um dos líderes do então recém-fundado movimento psicanalítico. Em 1913, ele afastou-se de Freud e gradualmente fundou sua própria escola, Psicologia Analítica.

Ao analisar a biografia dos quarenta homens entrevistados, Levinson ${ }^{87}$ chegou à conclusão de que a estrutura de vida individual desenvolve-se por meio de uma seqüência relativamente ordenada durantes os anos da maturidade. Os resultados da pesquisa mostraram que o caráter essencial da seqüência foi o mesmo para todos os pesquisados. Esse consiste em uma série de períodos de estabilização (construção de estrutura) alternados por períodos de transição (mudança de estrutura), que forma o curso do desenvolvimento psicossocial do adulto.

A principal tarefa de todas as fases estáveis é construir uma estrutura de vida. Para tanto, o indivíduo faz escolhas fundamentais sobre estudo, carreira, casamento, entre outras. A partir de então, persegue objetivos e valores dentro da estrutura criada. Em cada período de estabilização apresentam-se tarefas específicas, que caracterizam a fase dentro do ciclo vital e a distingue das outras etapas estáveis. Cada um desses períodos dura de seis a sete anos, no máximo dez, em cujo final a estabilidade conquistada passa a ser questionada e precisa ser modificada. Inicia-se então um período de transição.

A tarefa básica da fase transicional é reavaliar a estrutura existente até então, explorar as possibilidades de mudança, tanto em si próprio quanto no ambiente, e tomar decisões que irão formar a base de uma nova estrutura de vida, visando o ingresso em nova fase de estabilização. A fase transicional seria, assim, uma espécie de ponte entre dois grandes períodos estáveis. Ao estudar Levinson, Staude ${ }^{88}$ explica que é comum nesses períodos transitórios a pessoa sentir-se suspensa entre um

${ }^{87}$ Idem, ibidem, p. 49.

${ }^{88}$ STAUDE John-Raphael. O desenvolvimento adulto de C. G. Jung. Trad. Humberto Arcanjo Brito Rodrigues e Sílvia Helena Azarite Vianna. São Paulo, Cultrix, 1995, p. 35. 
passado não encerrado e um futuro que ainda não começou, lutando para superar o vazio entre eles.

\begin{abstract}
Embora grande parte do passado possa ser usada como base para o futuro, muitos elementos devem também ser desprezados e abandonados, geralmente com certa lamentação. Os períodos de transição são momentos de crise - e de oportunidade.
\end{abstract}

Deduz-se daí que crescer é renovar-se constantemente, aprendendo a lidar com as perdas de modo a abrir espaço para o novo. Quanto mais tempo se resiste em abrir mão do passado, mais tempo se leva para amadurecer. Isso não quer dizer, entretanto, que se deva evitar o luto das perdas.

Embora a ênfase inicial dos estudos estivesse centrada na crise da meiaidade, Levinson e seus colaboradores logo perceberam a necessidade e a possibilidade de investigar de que modo a vida adulta se desenvolve no decurso do tempo, demarcando como faixa de análise o período dos 18 aos 45 anos. Dessa forma, dividiram o percurso da vida em várias fases de estabilização e transição que se sucedem alternadamente, dentro de três etapas maiores do desenvolvimento: primeira etapa da fase adulta $(18$ - 40), idade adulta intermediária $(41$ - 60) e maturidade (60 em diante). Descrevem-se as principais características de cada fase, segundo Levinson ${ }^{89}$.

Transição da primeira fase adulta: passagem da adolescência para a primeira etapa da idade adulta

De acordo com Levinson ${ }^{90}$, a primeira etapa da idade adulta inicia-se aos 18 e termina aos 22 anos. O jovem nessa fase vê-se diante de dois desafios: encerrar a adolescência e ingressar na idade adulta. É importante nesse momento que ele questione a respeito da natureza do mundo dos adultos e o lugar do indivíduo dentro dele. Antes de tudo, o jovem deve modificar ou mesmo encerrar importantes relacionamentos com pessoas, grupos e instituições que até então lhe haviam dado suporte econômico e emocional. Isso inclui transformar as relações com a família. $O$

\footnotetext{
${ }^{89}$ LEVINSON, J. Daniel et alii. The Seasons of a Man's Life. New York, Ballantine Books, 1978, pp. 56-63.

${ }^{90}$ Idem, ibidem, p. 56.
} 
autor chega mesmo a dizer em conquista da independência financeira e saída da casa dos pais. Deve-se, entretanto, levar em consideração a época em que as pesquisas para a construção de sua teoria foram elaboradas - final da década de 1960 - quando os movimentos de contracultura e de rebeldia estavam no auge. Sabe-se que atualmente os jovens adultos permanecem na casa dos pais por muito mais tempo. De todo modo, Levinson já observava que o rompimento com a família nunca ocorre de modo radical, uma vez que há vários graus de ligação entre pais e filhos. Segundo ele, esse processo de separação continua durante toda a existência, sem que nunca esteja de fato terminado. O reconhecimento sobre a necessidade de libertar-se do passado, acarreta tristeza, desamparo e insegurança ante o desconhecido. Há sempre a sensação de que o futuro talvez não traga satisfações iguais àquelas experimentadas durante a adolescência.

Além disso, o jovem precisa começar as explorar as possibilidades oferecidas pela vida adulta e imaginar-se como participante dela. Para tanto, terá a incumbência de consolidar uma identidade adulta inicial e fazer algumas escolhas preliminares com vistas a formar uma base para viver no mundo adulto. No início desse período, o conhecimento, os valores e as aspirações de um jovem com relação a um estilo de vida adulta em particular podem ser bastante ambíguos ou influenciados por fantasias singulares. Por essa razão, ele precisa de aprendizado ulterior para adquirir maior conhecimento a respeito de si próprio e do mundo. A universidade e/ou o serviço militar são instituições que desempenham importantes papéis na vida do jovem nessa fase do desenvolvimento. Por meio delas, ele conquista a força necessária para romper com o passado e lançar-se ao futuro mais bem preparado, tanto interiormente quanto exteriormente.

\section{A primeira estrutura de vida adulta: entrando no mundo adulto}

A passagem da adolescência para a primeira etapa da idade adulta, como todas as fases de transição, é seguida por um período de estabilização, no qual uma nova estrutura de vida precisa ser construída. Esse período, segundo as pesquisas de Levinson ${ }^{91}$, situa-se aproximadamente entre 22 e 28 anos. O indivíduo precisa restabelecer o centro de gravidade da sua vida, a partir do qual possa relacionar o

${ }^{91}$ Idem, ibidem, p. 57. 
sentimento de si próprio como adulto com a sociedade na qual está inserido. Para tanto, ele passa a testar uma variedade de opções iniciais, concernentes a ocupação profissional, valores e estilos de vida, amizades e relacionamentos amorosos, incluindo aí, muitas vezes, o próprio casamento.

Trata-se, portanto, de um momento de buscas e importantes decisões, tomadas a partir de uma perspectiva dupla, que torna a etapa desafiante e estimulante ao mesmo tempo. Por um lado, o jovem adulto deve sentir-se livre para explorar diversas possibilidades, ou seja, experimentar diferentes tipos de envolvimento, manter em aberto várias opções e maximizar a quantidade de alternativas. Motivação nesse sentido deve ser buscada no sentimento de aventura e no desejo de vislumbrar as chances que o mundo adulto no qual ele está entrando pode lhe oferecer. Em contraste com esse anseio por novidades, no entanto, é necessário que ele crie uma estrutura estável, de modo a tornar-se mais responsável.

Encontrar o equilíbrio entre esses dois extremos nem sempre é tarefa fácil. Como demonstra o estudo de Levinson ${ }^{92}$, alguns indivíduos dedicam muito mais tempo e energia à exploração de oportunidades, enquanto outros desde cedo estabelecem firmes compromissos e começam a construir as bases do que acreditam ser uma estrutura de vida definitiva. Os riscos para o desenvolvimento estão presentes em ambos os casos. No primeiro, é possível que o jovem perca o foco de seus objetivos ao mudar constantemente de emprego e de relacionamento afetivo e/ou de amigos. No segundo, há o perigo de que venha a se arrepender profundamente das opções feitas de maneira prematura.

De todo modo, a entrada no mundo adulto nunca é feita sem que o indivíduo vivencie alguma espécie de crise. O grau de descontinuidade entre o mundo préadulto, no qual o adolescente cresceu, e o mundo adulto, no qual o homem deve erigir sua primeira estrutura de vida, pode ser moderado ou elevado, de acordo com as condições do ambiente e do preparo psicológico de cada um. Portanto, a profundidade do abalo psíquico nessa fase dependerá de um conjunto de fatores relacionados com o meio familiar e a própria cultura.

Segundo Levinson ${ }^{93}$, o indivíduo ingressa nesse período com um sonho a respeito do tipo de vida que espera para si no futuro. Inicialmente, o sonho pode ter

${ }_{92}$ Idem, ibidem, p. 80.

${ }^{93}$ Idem, ibidem, p. 91. 
pouca conexão com a realidade na qual ele está inserido. Nesse caso, o jovem sonharia, por exemplo, em tornar-se um grande homem de negócios, um político de destaque, um artista ou um esportista de fama internacional, vivenciando assim o mito do herói. No entanto, o sonho pode também relacionar-se com estruturas de vidas mais simples, tais como ser um marido exemplar, um bom pai de família, um respeitável membro de sua própria comunidade, entre outros. Sejam prosaicos ou grandiosos, os sonhos terão conseqüências fundamentais para o desenvolvimento adulto. Muitas mudanças de rumo na vida, por volta dos 40 anos, ocorrem pela sensação que a pessoa tem de haver traído ou comprometido seus sonhos de quando estava ingressando na vida adulta.

Outra constatação obtida por meio do estudo de Levinson ${ }^{94}$ e seus colaboradores foi fato de o desenvolvimento do homem ser bastante favorecido pela presença de um mentor nesse período. Vários anos mais velho, esse mentor é sempre alguém cuja experiência de vida está relacionada com o campo de conhecimento no qual o jovem pretende ingressar, seja um professor, um patrão, um chefe ou mesmo um colaborador em diversos sentidos. Em geral, o mentor representa uma figura transitória que reúne em si características de pai e amigo ao mesmo tempo. Uma de suas principais funções é a de viabilizar a realização do sonho do jovem, transmitindo a ele conhecimentos, encorajando-o, acreditando na sua capacidade. Por essa razão, uma vez tendo desempenhado seu papel, é comum que saia de cena, por contra própria ou pelo afastamento do próprio jovem.

É também tarefa bastante própria dessa fase o desenvolvimento da capacidade do indivíduo de relacionar-se intimamente. Leva algum tempo para que um jovem adulto aprenda a respeito de suas buscas internas e vulnerabilidades no que se refere à união afetiva. A idade pré-adulta torna-o apenas parcialmente preparado para esse empreendimento. Além disso, deixa um legado de culpa, ansiedade e mistificação, que complica seus esforços no sentido de encontrar a pessoa ideal para se casar. Porém, uma vez que essa pessoa é encontrada, ela passa a representar figura importante, com a ajuda da qual ele conta para facilitar seu ingresso no mundo adulto e realizar seus sonhos e ideais.

${ }^{94}$ Idem, ibidem, p. 97. 
Transição dos trinta anos: transformando a primeira estrutura de vida

Esta fase de transição, que se estende aproximadamente dos 28 aos 33 anos, representa uma oportunidade para o indivíduo eliminar eventuais falhas e limitações da primeira estrutura de vida e criar bases para uma estrutura mais satisfatória no sentido de completar a primeira etapa da vida adulta. Normalmente, aos 28 anos ele sente a vida tornando-se mais séria e questiona se deve continuar atuando da mesma forma que vinha fazendo até então ou empreender transformações. É como se algo interiormente lhe dissesse que esse é o momentochave para promover as mudanças necessárias. Se deixar passá-lo, será tarde demais.

O tipo de mudança elaborado nesse período pode diferir de homem para homem, porém no final dos trinta anos a estrutura de vida de todos é diferente do que aquela na qual ele vivia no início dessa década. Alguns passam por esse período de transição de modo relativamente tranqüilos, sem rupturas drásticas ou sentimentos de crise. Eles modificam suas vidas em alguns aspectos, a partir da estrutura que tinham no passado. Para eles, esse é um momento de reforma e não de revolução.

Para a maioria, no entanto, como demonstra o estudo de Levinson ${ }^{95}$, essa é uma fase de vida bastante estressante, caracterizada pela "crise dos trinta". Crises ocorrem quando $\mathrm{o}$ homem tem grandes dificuldades com as tarefas de desenvolvimento relativas ao período. Nesses casos, ele vivencia sua atual realidade de vida como intolerável, ao mesmo tempo em que se sente incapaz de formar uma nova estrutura. Há casos extremos de crises severas em que a própria vida parece ameaçada pelo perigo do caos e da dissolução, pela perda das esperanças no futuro.

Segundo Levinson ${ }^{96}$, esses três primeiros períodos - transição da primeira fase adulta, a primeira estrutura de vida adulta e a transição dos trinta anos - duram aproximadamente 15 anos. Juntos eles constituem a nova fase da maturidade inicial. O feliz ingresso nas próximas etapas depende substancialmente dos passos dados nesses períodos, especialmente a partir das transformações ocorridas durante a transição dos trinta anos, quando são feitas importantes novas escolhas ou se dá a

${ }^{95} \mathrm{ldem}$, ibidem, p. 58.

${ }^{96}$ Idem, ibidem, pp. 58-9. 
reafirmação das escolhas antigas. Se essas escolhas forem congruentes com os sonhos, talentos e possibilidades externas, elas proverão as bases para uma estrutura de vida satisfatória. Mas se forem discordantes e gerarem uma estrutura falha, o homem provavelmente sofrerá sérias conseqüências no próximo período, uma vez que até as melhores estruturas têm suas contradições e devem ser transformadas em tempo.

\section{A segunda estrutura de vida adulta: acomodação}

Esta fase começa a tomar forma no final da anterior e estende-se até aproximadamente os 40 anos. Representa o período auge da primeira etapa da vida adulta, quando o homem distribui sua energia entre todas as partes componentes da estrutura construída: trabalho, família, amizades, lazer, comunidade. Seja qual for a mais importante para ele, trata-se de realizar os sonhos e as aspirações da juventude.

Neste momento, duas tarefas apresentam-se como fundamentais. A primeira é a de conseguir um espaço dentro da sociedade, de modo a ancorar mais firmemente sua vida, desenvolvendo sua competência em uma ocupação escolhida. Dito de outra forma, o indivíduo ingressa em uma carreira profissional, na qual ele ainda é considerado um membro júnior. Dessa forma, sua segunda incumbência consiste em esforçar-se para evoluir dentro da área em que se encontra, objetivando o reconhecimento de seus pares até tornar-se sênior.

Portanto, no período de acomodação, o homem atua no sentido de estabelecer e realizar mais efetivamente seus empreendimentos pessoais, a partir de uma visão de projetos futuros. Refletir a respeito dos meios necessários para aprimorar-se é condição fundamental para o sucesso do desenvolvimento nessa etapa da vida, levando-se em consideração as metas a serem alcançadas, sejam elas quais forem: subir na escala social, obter fama, poder, dinheiro, qualidade de vida, ou até mesmo contribuir mais efetivamente com a comunidade. Essa faixa etária é caracterizada por um processo de evolução tão significativo, que Levinson ${ }^{97}$ a divide em dois momentos. O primeiro compreende a acomodação em si mesma,

${ }^{97}$ Idem, ibidem, p. 60. 
enquanto que o segundo consiste na ratificação dessa acomodação, quando o homem "torna-se dono de si próprio".

A despeito das conquistas e sucessos que possa alcançar nesta fase, o homem deverá aprender a lidar com as grandes responsabilidades e pressões que esse próprio avanço representa. Deverá também estar mais bem preparado para lidar com o conflito psíquico entre o menino que ele foi e o homem que se tornou, o qual nunca o abandonará completamente. Além disso, é bem possível que a relação com eventuais mentores que o acompanharam até então se tornem tempestuosas e encaminhem-se para o rompimento quase sempre doloroso.

Transição da meia-idade: passagem da primeira etapa da idade adulta para a idade adulta intermediária

Esta etapa, localizada aproximadamente entre os 40 e os 45 anos, representa uma ponte entre a idade adulta inicial e a meia-idade, no decorrer da qual o homem se depara com novas tarefas de desenvolvimento. A estrutura até então construída, que parecia sólida, volta a apresentar sinais de que necessita de reformas e modificações. De acordo com Levinson ${ }^{98}$, é quando o homem se questiona: "O que eu tenho feito da minha vida?", "O que realmente eu obtive de e ofereci para minha esposa, meus filhos, amigos, meu trabalho, minha comunidade - e de mim mesmo?", "O que de fato eu quero de mim mesmo e dos outros?". Enfim, o homem anseia por um tipo de vida em que seus atuais desejos, valores, talentos e aspirações possam ser expressos.

Alguns homens fazem poucos questionamentos ou buscas durante a transição da meia-idade. Eles aparentemente não são perturbados por questões difíceis relacionadas com o significado, o valor e a direção de suas vidas. Outros sentem que o caráter da vida está se modificando, mas o processo não traz sofrimento. Eles vivenciam uma espécie de transição administrada, sem crises. No entanto, para a grande maioria do universo pesquisado por Levinson ${ }^{99}$, esse é um período de grandes conflitos com o mundo tanto interior quanto exterior. Surgem questionamentos a respeito de quase todos os aspectos da vida e, ao mesmo tempo, a sensação de que é impossível empreender transformações tão facilmente

${ }^{98}$ Idem, ibidem.

${ }^{99}$ Idem, ibidem. 
como anteriormente, uma vez que qualquer mudança implicaria muito tempo em fase de transição.

De todo modo, as modificações impõem-se como necessárias, uma vez que é praticamente impossível levar uma vida feliz e saudável negligenciando as urgências internas. Durante os períodos de transição - especialmente o da meia-idade - as exigências internas falam mais alto na vida do indivíduo, impulsionando-o para a transformação da estrutura existente.

Entrando da idade adulta intermediária: construindo uma nova estrutura de vida

A partir dos questionamentos realizados na fase anterior, o homem deve fazer escolhas e formar uma nova estrutura de vida. A necessidade de mudanças apontada no período precedente pode ter sido prenunciada por algum fato de natureza drástica, tais como mudança de emprego, divórcio ou caso amoroso, doença séria, morte de alguém querido, mudança para um novo local. Algumas vidas podem não apresentar mudanças notáveis, porém, quando observadas mais de perto demonstram pequenas transformações que fazem consideráveis diferenças. Um homem pode continuar casado com a mesma mulher, mas o caráter do seu relacionamento familiar pode ter-se modificado para melhor ou para pior. Também a natureza do seu trabalho pode ter sido alterada. Uma hipótese é a de que ele pode estar simplesmente contando o tempo para se aposentar. Outra é a de que seu trabalho tornou-se opressivo ou, ao contrário, tornou-se mais criativo e satisfatório.

A nova estrutura que surge na meia idade varia de acordo com a capacidade de adequação no que diz respeito à vida interior. Alguns homens sofreram sérias frustrações na infância e na juventude que os tornaram pouco hábeis para empreender mudanças na meia-idade. Outros formam novas estruturas, porém, pouco satisfatórias das necessidades psíquicas mais profundas e verdadeiras. Há ainda aqueles que, na meia-idade, encontram-se completamente satisfeitos com suas conquistas e transformações. Eles vivenciam o novo período como um dos mais plenos e gratificantes de suas vidas. Esses em geral são aqueles menos tiranizados pelas ambições, paixões e ilusões da juventude. 
Os subseqüentes períodos da meia idade

Por volta dos 50 anos o homem já formou uma estrutura de vida na qual se baseia o desenvolvimento na idade adulta intermediária. A partir daí, os estudos de Levinson ${ }^{100}$ e de seus colaboradores não tiveram continuidade. Eles acreditam que haja ainda uma fase de transição entre 50 e 55 anos, seguida pela construção de uma segunda estrutura adulta intermediária. Porém, não há descrição sobre os processos de desenvolvimento referentes a esses períodos.

\subsubsection{Terri Apter}

Entre os mais recentes estudos publicados sobre o ingresso no mundo adulto, encontra-se o de Terri Apter ${ }^{101}$, psicóloga americana, radicada na Inglaterra. A partir de extensa pesquisa com seiscentos jovens, coordenada pelo Economic and Social Research Council da Grã-Bretanha, em 1997, e de trinta e duas entrevistas individuais realizadas por ela própria, de 1994 a 2000. Apter levantou importantes informações sobre os problemas, as angústias e os sofrimentos de indivíduos entre 18 e 24 anos.

Nessa fase limiar entre um estágio de desenvolvimento e outro, todo jovem vê-se diante de questões desafiantes, para as quais ele não encontra soluções facilmente. "Como vou me sair como um deles - um dos adultos?", "Estarei à altura de enfrentar um mundo mais amplo?", "Serei capaz de aprender o que eu preciso saber?", "Quem serão meus amigos?" são perguntas que os jovens se fazem e que, se perquiridas atenciosamente pelos adultos, revelam as carências e inseguranças típicas da faixa etária. Segundo Apter ${ }^{102}$, os adultos - pais, professores, patrões em vez de serem recipientes seguros para as ansiedades dos jovens, ao contrário, com freqüência escutam muito mal seus pedidos de socorro.

De acordo com as entrevistas realizadas pela psicóloga, as crianças estão entrando muito depressa na puberdade e demorando mais para atingirem a idade adulta. A constatação permite concluir que a fase de moratória, conforme descrita por Erikson e retomada por Calligaris, esteja cada vez mais extensa, intensificando

\footnotetext{
${ }^{100}$ Idem, ibidem, p. 62.

${ }^{101}$ APTER, Terri. O mito da maturidade: o que os adolescentes precisam para se tornarem adultos. Trad. Talita M. Rodrigues. Rio de Janeiro, Rocco, 2004.

${ }^{102}$ Idem, ibidem, p.14.
} 
os problemas relacionados ao desenvolvimento durante a adolescência e postergando as tarefas específicas de cada fase do desenvolvimento. O processo de preparação para a vida adulta, hoje em dia, é muito mais longo, haja vista as exigências de treinamento e formação educacionais impostas pela sociedade como pré-requisitos para a ocupação profissional em diversas áreas. Dessa forma, sair da casa dos pais atualmente tem-se tornado tarefa muito mais complicada do que já foi no passado. Os próprios estudos de Apter ${ }^{103}$ revelam esse fato objetivamente:

Quarenta por cento das mulheres jovens que saem de casa, e cinqüenta por cento dos homens jovens, retornam em seguida. Sair de casa é uma transição intermitente e não marca a verdadeira independência dos pais, seja emocional ou financeira. [...] Estabelecer-se como um adulto numa casa independente era um dos sintomas de maturidade considerados como coisa normal. Hoje, devido ao seu alto custo, essa é uma meta distante, facilmente frustrada. É cada vez maior o número de jovens que voltam a morar com os pais depois de formados, fazendo da casa deles a base para seus primeiros passos na carreira: cinqüenta e oito por cento dos jovens entre vinte e dois e vinte e quatro anos estão vivendo agora com os pais, e trinta por cento daqueles entre vinte e quatro e trinta anos moram com os pais. Hoje, um jovem, homem ou mulher, leva de cinco a dez anos para trocar de base, totalmente, da casa dos pais para a sua própria casa.

Ao contrário do que se passava até as décadas de 1950 e 1960, quando os jovens, então considerados rebeldes, criticavam e negavam os valores tão fortemente esquematizados e previsíveis da maturidade, atualmente, eles sentem-se perdidos justamente pela falta de parâmetros e pela confusão de conceitos divergentes relacionados com o que significa ser adulto hoje em dia. Não há na sociedade contemporânea padrões claramente definidos que possam servir como referência para um indivíduo certificar-se de que esteja ingressando de maneira adequada na vida adulta. A entrada nessa fase da vida está relacionada na atualidade mais às atitudes individuais do que a um conjunto de normas universalmente aceito.

Para identificar o indivíduo que se encontra na passagem entre a adolescência e a idade adulta, entre 18 e 24 anos, Apter ${ }^{104}$ utiliza o termo

103 Idem, ibidem, p.18.
${ }^{104}$ Idem, ibidem, p.20. 
"thresholder" ${ }^{105}$, como referência a esse momento da vida em que se está simultaneamente na infância e na maturidade. É justamente por sentirem-se nãopertencentes a um período nem a outro que os jovens sofrem de instabilidade emocional e falham diante de questões em que autoconfiança, discernimento e controle são exigidos. Constitui-se motivo de sofrimento para eles o fato de constatarem, nessa fase, que os contextos nos quais se desenvolvem - família, vizinhança, escola, emprego - não funcionam em conjunto, obrigando-os a transitarem entre o desempenho de diferentes papéis sociais, sem que disponham de versatilidade para tanto. Nesse momento, eles necessitam de orientadores, que são procurados na figura dos próprios pais ou de adultos ligados às mais diferentes instituições sociais: professores, religiosos, terapeutas, entre outros. Mesmo assim, na maior parte das vezes, esse auxílio é interpretado como insatisfatório, uma vez que é característica dos jovens a sensação de falta de apoio generalizada e a de que ninguém é capaz de ajudá-los a compreenderem-se a si mesmos. Em conseqüência dessa situação, é normal lançarem mão de mecanismos de defesa, tais como hábitos de distração e negação, que podem cristalizar-se em padrões de comportamento para a vida toda.

Mesmo quando os jovens transitam por essas encruzilhadas com ar de que "está tudo bem", eles vivem uma silenciosa tragédia de sofrimentos desnecessários, que poderia - e deveria - ser aliviada. Porque esse sofrimento gera inseguranças e reduz a motivação numa época de momentos decisivos em potencial, quando as escolhas podem mudar para sempre o curso da adaptação e do sucesso na vida adulta. ${ }^{106}$

Grande parte da responsabilidade dessa conjuntura, Apter ${ }^{107}$ atribui ao que ela chama de "mito da maturidade", segundo o qual a idéia de ser maduro significa ser independente, no sentido de estar separado ou ser autônomo. Ao acreditarem nesse mito - e, por conseguinte, fazerem os jovens acreditarem também -, os adultos estariam, no entender da psicóloga, prejudicando a passagem dos adolescentes para a idade adulta, pela idealização exagerada da independência e

${ }^{105}$ Neologismo em língua inglesa criado pela autora a partir do termo "threshold", que em Português, de acordo com o contexto, poderia ser traduzido por "limiar", "soleira de porta", "começo", "princípio".

${ }^{106}$ APTER, Terri. O mito da maturidade: o que os adolescentes precisam para se tornarem adultos. Trad. Talita M. Rodrigues. Rio de Janeiro, Rocco, 2004, p.22.

107 Idem, ibidem, p.25. 
da autoconfiança. A crença de que a maturidade tenha como marca a separação dos amores e necessidades infantis faz com que a dependência, ainda perfeitamente normal nesse período, seja compreendida como fraqueza. Dessa forma, muitos pais, professores, mentores, patrões e demais adultos, em nome do amor e daquilo que julgam ser o melhor para o desenvolvimento, retiram o apoio emocional, prático ou financeiro, deixando que os jovens solucionem os próprios problemas ou até mesmo que eles sofram sozinhos as conseqüências de erros e falsos julgamentos.

Ocorre, porém, ainda de acordo com o pensamento de Apter ${ }^{108}$, que o desenvolvimento humano é relacional, ou seja, as pessoas nascem e são criadas em relacionamentos de dependência e amor. Por mais que os indivíduos se transformem durante o processo de crescimento, por mais que os seres amados e as relações com eles se modifiquem com o passar dos anos, a união e certo grau de dependência mútua permanecem pela vida inteira. Portanto, acreditar no mito da maturidade significaria um desserviço ao equilíbrio necessário para o ingresso na vida adulta.

A conclusão a que muitos de nos chegam, porque continuamos a sentir que temos vínculos muito fortes (tanto positivos quanto negativos) com nossos pais, é que em parte continuamos presos à adolescência. Sentimos que existe algo errado em nós se não tivermos "conquistado" a separação psicológica de nossos pais. Paralelamente, reprimimos o impulso de continuarmos perto de nossos filhos. Acreditamos que continuar apegados a eles é uma atitude egoísta e pouco saudável. ${ }^{109}$

Apter defende a necessidade de os pais de hoje estarem presentes na vida dos filhos por um período muito mais longo do que aquele normalmente observado no processo de formação educacional das gerações anteriores. Isso não significa dizer que a passagem da adolescência para a vida adulta no passado fosse mais fácil no passado. Os desafios dessa transição sempre existiram. Porém, com as mudanças verificadas na sociedade contemporânea, em que juventude passou a ser um valor até mesmo para os mais idosos, em que os avanços tecnológicos revolucionaram radicalmente os meios de produção e os conceitos sobre o que seja trilhar uma carreira profissional; os jovens estão mais do que nunca perdidos diante

\footnotetext{
${ }^{108}$ Idem, ibidem, p.244.

${ }^{109}$ Idem, ibidem.
} 
da quantidade de conhecimentos que precisam acumular, se quiserem ocupar postos de trabalho que lhes garantam as condições mínimas de uma vida digna de qualidade e segurança.

Se, no passado, as crianças entravam de maneira razoavelmente rápida na vida adulta, assumindo papéis sociais definidos, ganhando salários condizentes e casando-se relativamente jovens, hoje em dia, as oportunidades estão cada vez mais exíguas. A partir de seus estudos, constata Apter ${ }^{110}$ :

Mesmo nos meados do século XX, havia muitas oportunidades para encontrar um nicho seguro, com um emprego, uma família e uma comunidade. Hoje, os jovens adultos atingem diferentes estágios da idade adulta em várias épocas. Alguns ganharão salários altíssimos antes mesmo de pensarem em ter uma família. Outros terão filhos enquanto ainda são sustentados pelos pais. Alguns terão diplomas de nível superior, mas serão forçados por economia a morar com os pais. Alguns serão mimados no colégio e depois enfrentarão grandes responsabilidades no emprego. Hoje não existem mais marcos nítidos nesta estrada.

Apoiada nessas razões, Apter insiste em desmitificar a entrada na maturidade como um momento de rupturas com o passado e de conquista da independência com relação aos pais. A autora acredita que, se os genitores estiverem atentos às diferentes formas que a solidão, as perdas e as confusões emocionais assumem nas manifestações comportamentais dos filhos, eles aprenderão a localizar os sinais de perigo e estarão aptos para ajudar a corrigir os problemas característicos da transição para a idade adulta.

A abordagem de Apter sobre transição para a vida adulta difere da dos demais estudiosos naquilo que ela traz de recomendação, tanto para os jovens quanto para os adultos responsáveis, sobre as possíveis maneiras vivenciar o período, tendo em vista a minimização dos conflitos. Referentemente às condutas típicas dos jovens nessa fase, o trabalho da psicóloga ratifica as observações de importantes pesquisadores do passado. Utilizando estudos de caso como referência e ilustração, a autora discorre sobre: 1) transtornos alimentares, motivados pela transformação do corpo; 2) busca por identificação e formação de identidade; 3) necessidade de fazer escolhas relacionadas à carreira profissional, incluindo-se aí o

${ }^{110}$ Idem, ibidem, p.246. 
ingresso na universidade; 4) relacionamento com mentores; 5) atração sexual e descoberta da paixão; 6) necessidade de aprender a lidar com mágoas e ressentimentos, relativamente tanto ao amor quanto às amizades; 7 ) necessidade de sair-se vencedor em contraposição com o medo do sucesso; 8) necessidade de encontrar estabilidade e estabelecer pares no mundo adulto; 9) angústia com relação ao tempo; 10) aprendizagem com relação a limites próprios e impostos pelo mundo externo; 11) casamento como atalho para a maturidade; 12) experiência no mundo material, com destaque para a administração do dinheiro, e 13) casos de autoflagelação e suicídio.

Ao argumentar a respeito da inadequação do mito da maturidade para processo de desenvolvimento dos jovens, Apter investe contra os contos de fadas. Segundo a psicóloga, esse gênero literário é responsável pela presença no imaginário da humanidade da idéia de que o aprendizado e o crescimento devem-se dar longe da família. Diz ela ${ }^{111}$ :

Este modelo fixou-se na imaginação: sozinho, expulso de casa pelo pai, o menino mostra o seu valor e se torna um homem digno. O seu rito de passagem é através de uma floresta ou deserto para onde ele é lançado por uma família que o deprecia. Ainda mantemos este modelo de sair de casa e seguir o próprio caminho. Ele molda as reações dos pais diante dos próprios filhos e filhas. Ele molda as expectativas que os jovens têm quanto a si mesmos.

O conto original de separação e triunfo surgiu numa sociedade muito diferente. $O$ ideal de partir e retornar como um rito de passagem nasceu numa época de maior coesão e controle familiar. A transição de criança - com suas associações de necessidade e dependência - a adulto - com suas associações de conhecimento e poder - mudou com o tempo.

Ante essas afirmações, é de se crer que Apter tenha desconsiderado o caráter simbólico dos contos de fadas e desprezado importantes e consagradas análises psicológicas das narrativas maravilhosas que compõem o acervo do que conhecemos hoje como Literatura Infantil Clássica. Nessas, o percurso do herói que abandona o lar, seja por que motivo for, simboliza uma "viagem" às profundezas do inconsciente de onde emerge com a consciência fortalecida para enfrentar as

${ }^{111}$ Idem, ibidem, p.248. 
vicissitudes do tornar-se adulto. Em nenhum momento, o lançar-se na floresta desconhecida é compreendido como um apelo à saída real da casa dos pais. A visão simbólica dos contos de fadas é coincidente tanto entre os adeptos da psicologia do ego quanto entre os que professam a psicologia do self. Apenas para citar um pensamento de cada corrente, reproduz-se, como representante da primeira, trecho do que fala Bettelheim ${ }^{112}$ :

Através dos séculos (quando não dos milênios) durante os quais os contos de fadas, sendo recontados, foram-se tornando cada vez mais refinados, e passaram a transmitir ao mesmo tempo significados manifestos e encobertos - passaram a falar simultaneamente a todos os níveis da personalidade humana, comunicando de uma maneira que atinge a mente ingênua da criança tanto quanto a do adulto sofisticado. Aplicando o modelo psicanalítico da personalidade humana, os contos de fadas transmitem importantes mensagens à mente consciente, à pré-consciente, e à inconsciente, em qualquer nível que esteja funcionando no momento.

Como representativo do pensamento da Psicologia Analítica de Carl Gustav Jung, selecionou-se o seguinte trecho retirado de Franz ${ }^{113}$ :

Apesar de terem características muito humanas, esses heróis de contos de fadas não são, pois, inteiramente humanos. Isso porque não são apenas tipos de seres humanos, mas arquétipos, não podendo, por conseguinte, ser diretamente comparados com o ego humano.

Os depoimentos de Bettelheim e Franz não autorizam, portanto, compactuar com o pensamento de Apter no que diz respeito à invalidade dos contos de fadas para os dias atuais. Pode-se concordar com a defesa que a psicóloga de Chicago faz da necessidade de os pais estarem próximos de seus filhos, oferecendo apoio emocional e material, durante todo o processo de transição para a vida adulta, mas

${ }^{112}$ BETTELHEIM, Bruno. A psicanálise dos contos de fadas. Trad. Arlene Caetano. 10.reimp., Rio de Janeiro, Paz e Terra, 1980, p. 14.

${ }^{113}$ FRANZ, Marie-Louise von. O significado psicológico dos motivos de redenção nos contos de fada. Trad. Álvaro Cabral. São Paulo, Cultrix, 1993, p. 11. 
daí a comungar com sua idéia a respeito das narrativas maravilhosas vai uma distância muito grande. Em apoio ao que aqui se defende, testemunha Coelho ${ }^{114}$ :

[...] estamos vivendo um momento propício à volta do maravilhoso, em cuja esfera o homem tenta reencontrar o sentido último da vida e responder à perguntas-chave de sua existência: Quem sou eu? Por que estou aqui? Para onde vou? É no sentido dessa inquietação existencial que vemos o atual fascínio pela redescoberta dos tempos inaugurais / míticos, nos quais a aventura humana teria começado. [...] O onírico, o fantástico, o imaginário deixaram de ser vistos como pura fantasia, para serem pressentidos como portas que se abrem para verdades humanas ocultas.

É no sentido da percepção de Coelho que, neste trabalho, buscou-se descrever psicologicamente o processo de transição para vida adulta da personagem Casemiro, de O relógio do mundo, narrativa de Lino de Albergaria pertencente ao gênero do conto maravilhoso.

${ }^{114}$ COELHO, Nelly Novaes. O conto de fadas: símbolos, mitos, arquétipos. São Paulo, DCL, 2003, p. 17. 


\section{A alquimia do "adultescer"}

Duas cidades: uma comum, uma mágica. Entre elas, uma floresta e um segredo. A cidade comum é Cravo Branco, ao Sul; a mágica, é Cucura, ao Norte. O segredo é uma mina de ouro subterrânea, escondida abaixo do leito do rio que corta a densa mata. Esse é o tópos a partir do qual Lino de Albergaria cria O relógio do mundo ${ }^{115}$, no ano de 1989.

A estória inicia-se quando os habitantes de Cravo Branco ficam sabendo da existência do ouro pelo "último índio". A partir de então, dominados pela cobiça, invadem a mata à procura do rico minério. É quando a gente de Cucura decide socorrer a floresta, porque precisava dela para manter-se encantada. A mata por sua vez também reage, fazendo brotar novas árvores, que, sempre maiores e com mais vigor, começam a invadir Cravo Branco.

Lá, morava Casemiro Correia, caçula de uma família de doze filhos homens, cujo pai era o Capitão. Decidido a lutar contra as forças de Cucura, o homem mandava um filho após o outro enfrentar a floresta. Mas, amedrontados, todos fugiam. Em vez de seguirem rumo Norte, partiam para o Sul. Até que chegou o dia em que só sobrou Casemiro Correia. O menino passava os dias a tratar do jardim de casa, atento para que o mato não estragasse os canteiros de cravo branco, que ele tão cuidadosamente cultivava. Essa situação, no entanto, não demora a se modificar.

Bastou que uma coruja piasse, primeiro de noite, depois de dia, para que Cornélio Correia, o Capitão, mandasse à luta o último filho, impondo ao garoto a missão de acabar com a vida do pássaro, considerado mau agourento. Intuitivamente, porém, Casemiro sabia que a coruja voaria para algum lugar misterioso, sobre o qual ele tinha muita curiosidade. Mesmo armado com a pesada espingarda que o pai o obrigara a carregar, ele não tinha a menor certeza se devia ou não matar a ave. Cheio de dúvidas e conflitos, o garoto embrenha-se na mata, sem saber que uma borboleta cor de prata, símbolo de Cucura, o seguia. Também não se dava conta, tampouco, do fato de que, desde que acordara naquele dia, vinha diminuindo de tamanho e havia perdido mais alguns centímetros ao entrar na floresta.

115 Ilustrações Rogério Borges. 16.ed., São Paulo, Atual, 2005, 64 p. 
Daí em diante, rumo a seu destino, o garoto irá viver várias aventuras: desde cair num poço profundo e ver-se no interior de uma gruta, onde encontra espécies de índios guardiões d'O relógio do mundo, local sagrado onde o "ferro amadurece em ouro", até ser recebido pelos reis "sem idade" de Cucura. Durante a jornada de três anos, Casemiro enfrenta duras provações impostas ora por animais selvagens, como os caititus, porcos-do-mato, ora pelas intempéries, como a cruviana enlouquecida, ora por seres sobrenaturais, como a Caipora. No final, vê-se transformado em adulto, pronto para retornar a Cravo Branco, casar-se com Cordélia Camarão e assumir, no lugar que era de seu já falecido pai, o comando da cidade. Sua missão será a de restabelecer o equilíbrio entre os dois mundos, perdido como conseqüência da ambição dos homens comuns.

Sobre o processo de criação da obra, diz o autor ${ }^{116 .}$

O relógio do mundo foi minha primeira tentativa de um conto de fadas ou de uma história maravilhosa. Pesquisei em Câmara Cascudo. O livro é uma homenagem a ele, pois as personagens e lugares começam todos com a letra "C", a inicial de Cascudo. [...] É claro que tem também influência de Vladimir Propp, Marie-Louise Von Franz e de outros autores.

\subsection{O relógio do mundo: a transição de Casemiro}

Para o estudo da obra O relógio do mundo, de Lino de Albergaria, tomou-se por base a Psicologia Analítica de Carl Gustav Jung, bem como os avanços dos estudos nessa área, de modo a interpretar a narrativa tanto relativamente ao todo significativo que se constitui a obra quanto ao percurso específico do protagonista. Considerado um dos fundadores da psicologia moderna e conhecido como um dos grandes psiquiatras do século $X X$, Jung e suas teorias suscitaram, e continuam suscitando, nos meios científicos opiniões das mais controvérsias.

Uma das principais causas da polêmica em torno de seu pensamento talvez tenha sido a reintrodução que ele faz na psicologia do termo alma. Deve-se esclarecer, no entanto, que o significado que Jung dá para alma nada tem a ver com o conceito abstrato da filosofia religiosa. Trata-se de um dado da experiência, uma

${ }^{116}$ E-mail enviado a este pesquisador em 8 de junho de 2005. 
presença existencial em si mesma no seu relacionamento com o mundo. Embora essa vivência seja individual, é uma realidade objetiva.

Outro ponto causador de celeuma no mundo acadêmico foi o rompimento entre Jung e Sigmund Freud, provocado pelas concepções diferentes de ambos a respeito dos conteúdos inconscientes. Freud considerava que todo conteúdo inconsciente estaria de alguma forma sempre relacionado com algum trauma de natureza sexual. Mesmo admitindo que muitos sonhos apresentassem imagens e associações análogas a idéias, mitos e ritos primitivos, ele acreditava que esses conteúdos fossem "resíduos arcaicos", como se o inconsciente atuasse como apêndice do consciente. Jung, por seu lado, defendia que associações e imagens desse tipo eram observadas por toda parte, fosse o sonhador instruído ou analfabeto, inteligente ou obtuso, o que levava a crer numa espécie de funcionamento autônomo do inconsciente.

Deixando de lado a polêmica, busca-se esclarecer, antes de tudo, alguns conceitos essenciais ao pensamento junguiano. Para o médico e psiquiatra suíço, o inconsciente é formado por uma camada mais ou menos superficial, de natureza pessoal, e uma outra mais profunda, de natureza universal, que constitui um substrato psíquico comum, suprapessoal, que existe em cada indivíduo. A primeira camada recebeu o nome de inconsciente pessoal e a segunda foi chamada inconsciente coletivo, cujos conteúdos o próprio Jung ${ }^{117}$ explica:

Uma existência psíquica só pode ser reconhecida pela presença de conteúdos capazes de serem conscientizados. Só podemos falar, portanto, de um inconsciente na medida em que comprovamos os seus conteúdos. Os conteúdos do inconsciente pessoal são principalmente os complexos de tonalidade emocional, que constituem a intimidade pessoal da vida anímica. Os conteúdos do inconsciente coletivo, por outro lado, são chamados arquétipos.

Ao empregar o termo arquétipo, no que concerne aos conteúdos do inconsciente coletivo, Jung está tratando de tipos primordiais, isto é, de imagens universais que existiram desde os tempos mais remotos. Porém, ele faz questão de ressaltar que, para a psicologia, o conceito de arquétipo é empregado de modo

117 JUNG, Carl Gustav. Os arquétipos e o inconsciente coletivo. Trad. Maria Luiza Appy e Dora Mariana R. Ferreira da Silva. Petrópolis, Vozes, 2000, p. 16. 
diferente daquele encontrado na representação dos mitos e dos contos de fadas. Nestes, a expressão dos conteúdos do inconsciente já se transformaram com o passar do tempo em fórmulas conscientes definidas, historicamente elaboradas e transmitidas segundo a tradição. No campo semântico do pensamento psicológico, no entanto, "o arquétipo representa essencialmente um conteúdo inconsciente, que se modifica através de sua conscientização e percepção, assumindo matizes que variam de acordo com a consciência individual na qual se manifesta" ${ }^{118}$. Para diferenciar o emprego do conceito em cada uma das duas circunstâncias, Jung cunhou a expressão idéias arquetípicas, reservando esta para o âmbito do mito e do conto de fadas.

Demarcar claramente essa divisão é de fundamental importância neste contexto, pois, no processo de análise literária aqui desenvolvida está-se trabalhando referencialmente com o sentido de idéias arquetípicas e não de arquétipo na definição junguiana, uma vez que foram utilizadas descrições e interpretações de símbolos já conscientemente conhecidas no seio de diferentes culturas e universalmente divulgadas. O termo arquétipo, quando empregado no presente trabalho terá, na maioria das vezes, as acepções que lhe são dadas no estudo dos mitos, isto é, as de imagem primordial, padrão primitivo, modelo das origens ou fonte primacial; as mesmas que Ihe empresta, por exemplo, Eliade ${ }^{119}$. Quando a expressão for utilizada no sentido junguiano, o contexto de uso será desenvolvido de modo a dirimir qualquer ambigüidade conceitual. Esclarecida essa questão terminológica, cabe descrever o que Jung entende por símbolo.

Para Jung ${ }^{120}$, símbolo é um termo, um nome ou mesmo uma imagem que, embora possa ser familiar na vida diária de qualquer pessoa, possui conotações especiais além do seu significado evidente e convencional. Implica alguma coisa vaga, desconhecida ou oculta para o pensamento consciente.

Assim, uma palavra ou uma imagem é simbólica quando implica alguma coisa além do seu significado manifesto e imediato. Esta palavra ou esta imagem tem um aspecto "inconsciente" mais amplo, que nunca é precisamente definido ou de todo explicado. $E$ nem podemos ter

\footnotetext{
118 Idem, ibidem, p. 17.

119 ELIADE, Mircea. Mito e realidade. Trad. Pola Civelli. 6.ed., São Paulo: Perspectiva, 2002, p. 101.

120 JUNG, Carl Gustav. "Chegando ao inconsciente". In: JUNG, Carl Gustav et. alii. O homem e seus símbolos. Trad. Maria Lúcia Pinho. 4.ed., Rio de Janeiro, s/d., p. 21.
} 
esperanças de defini-la ou explicá-la. Quando a mente explora um símbolo, é conduzida a idéias que estão fora do alcance da nossa razão.

Segundo o psiquiatra, o homem produz símbolos, inconsciente e espontaneamente, na forma de sonhos, mas não só. Os símbolos aparecem também em todos os tipos de manifestações psíquicas: pensamentos, sentimentos, situações e atos. Até mesmo objetos inanimados podem desempenhar papéis simbólicos. Diz-se que algo se configura como símbolo quando, por intermédio desse algo, se torna possível entrar em contato com conteúdos do inconsciente pessoal e/ou coletivo. Embora um indivíduo produza símbolos que se relacionam com sua experiência pessoal, ou, em outras palavras, embora cada símbolo possa ter significados diferentes para cada pessoa, emergem na mente símbolos cujos sentidos apresentam caráter universal.

Jung ${ }^{121}$ classifica os símbolos em dois grandes tipos: os símbolos naturais e os símbolos culturais. Ele explica que os primeiros são derivados dos conteúdos inconscientes da psique e, portanto, representam um número imenso de variações das imagens arquetípicas essenciais. Por meio da investigação do sentido do símbolo natural, pode-se, em alguns casos, chegar às suas origens mais arcaicas isto é, a idéias e imagens encontradas nos mais antigos registros e nas mais primitivas sociedades. Já os símbolos culturais, por outro lado, são aqueles empregados para expressar o que Jung chama de "verdades eternas", a exemplos dos muitos utilizados por várias religiões. Ao longo do tempo, esses símbolos passam por várias transformações e mesmo por processos de reelaboração mais ou menos conscientes, tornando-se assim imagens coletivas aceitas pelas sociedades civilizadas. Na prática da psicoterapia analítica junguiana, o papel dos símbolos é dar significação à vida do homem, de modo a auxiliá-lo a chegar o mais longe possível no seu processo de individuação.

Processo de individuação é a expressão que Jung emprega para referir-se ao caminhar lento e imperceptível do indivíduo rumo ao crescimento psicológico. Ao analisar seus pacientes, Jung descobriu que a seqüência de sonhos de uma pessoa, durante sua vida, parece obedecer a uma determinada configuração ou esquema que, além de dizer respeito à experiência cotidiana de quem sonha, faz parte de

${ }^{121}$ Idem, ibidem, p. 93. 
uma única e grande teia de fatores, os quais narram os estágios por que passa essa pessoa em seu processo de desenvolvimento psíquico.

Como a linguagem que emerge do inconsciente é simbólica, para compreender essa história narrada pelos sonhos, ou por outros meios de acesso ao conteúdo inconsciente, é preciso interpretar os símbolos. Os símbolos que aparecem nos sonhos, para além de relacionarem-se à vivência imediata, isto é, ao contexto sociocultural daquele que sonha, podem expressar conteúdos arquetípicos relacionados com o acervo cultural simbólico de toda humanidade, em todos os tempos. Isso implica dizer que há símbolos produzidos pelos sonhos cuja natureza e origem não são individuais, mas sim coletivas.

Conforme diz Jung, "muitos sonhos apresentam imagens e associações análogas a idéias, mitos e ritos primitivos". 122 Essas associações configuram-se como o elo entre o mundo racional da consciência e o mundo do instinto, elo esse fundamental para que o homem evolua psiquicamente. Para o psicanalista, o ser humano, na infância, está bastante próximo do sentido da totalidade, à qual ele dá o nome de self, que se constitui o todo composto pelos lados racional e instintivo da psique. Esse sentido de totalidade, no entanto, é perdido a partir do momento em que o ego se desenvolve. Porém, mais tarde, para que o homem possa atingir a maturidade psíquica, é necessário empreender um retorno à totalidade, isto é, ao self.

A "história" individual de como se dá esse retorno é narrada pelos sonhos, por meio da linguagem simbólica. Compreender essa linguagem é compreender os meandros do caminho que cada indivíduo percorre para reencontrar-se com a totalidade de seu ser, composta de um lado consciente e outro inconsciente. Quanto mais o homem se afastar de um desses lados, maior será seu desequilíbrio psíquico. Harmonizar consciente e inconsciente é, pois, tarefa incessantemente realizada pela psique humana no sentido de galgar etapa por etapa o processo de crescimento psicológico. A cada estágio de evolução, o homem vivencia psiquicamente experiências que estão relacionadas, isto é, que são análogas às narrativas míticas que explicam a origem, a formação e as fases de evolução das várias culturas e o desenvolvimento dos indivíduos no interior delas.

122 Idem, ibidem, p. 47. 
O homem contemporâneo, porém, ao identificar-se cada vez mais com a razão, vem sistematicamente afastando-se de seus instintos básicos, e conseqüentemente do pensamento mítico, o que the dificulta compreender mensagens simbólicas que emergem do inconsciente, sejam elas oriundas dos sonhos ou de outros meios. Ao privilegiar o lado racional, o ser humano passa a valorizar apenas o conhecimento teórico que se pode obter por meio da consciência civilizada. Mas o fato de ignorar o próprio instinto básico, não significa que esse tenha deixado de existir, apenas que perdeu o contato com a consciência e, dessa forma, é obrigado a afirmar-se de maneira indireta. Isto significa dizer que o acesso ao conteúdo do inconsciente se dá por intuição. É nesse sentido que se manifesta a mensagem simbólica presente em $O$ relógio do mundo, que metaforiza, pelo conjunto dos símbolos mobilizados, o processo de individuação da personagem Casemiro Correia, por meio da representação do mito do herói e daquilo que ele expressa referentemente ao processo de passagem da adolescência para a vida adulta (ver análise comparativa, Cap. 4).

Henderson ${ }^{123}$, discípulo de Jung, refere-se ao mito do herói da seguinte forma:

O mito do herói é o mais comum e o mais conhecido em todo o mundo. Encontramo-lo em todo o mundo na mitologia clássica da Grécia e de Roma, na Idade Média, no Extremo Oriente e entre as tribos primitivas contemporâneas. Aparece também em nossos sonhos. Tem um poder de sedução dramática flagrante e, apesar de menos aparente, uma importância psicológica profunda. São mitos que variam muito nos seus detalhes, mas quanto mais os examinamos mais percebemos o quanto se assemelham na estrutura. Isto quer dizer que guardam uma forma universal mesmo quando desenvolvidos por grupos ou indivíduos sem qualquer contato cultural entre si - como, por exemplos, as tribos africanas e os índios norte-americanos, os gregos e os incas do Peru.

Segundo ainda o autor, o mito do herói revela um significado psicológico de importância fundamental tanto para o indivíduo, no seu esforço em encontrar e afirmar sua personalidade, quanto para a sociedade no seu todo, na sua necessidade semelhante de estabelecer uma identidade coletiva. É esse significado

${ }^{123}$ HENDERSON, Joseph L. "Os mitos antigos e o homem moderno". In: JUNG, Carl Gustav et. alii. o homem e seus símbolos. Trad. Maria Lúcia Pinho. 4.ed., Rio de Janeiro, s/d., p.110. 
que se busca descrever com relação à trajetória de Casemiro entre sua cidade natal, Cravo Branco, e a cidade de pedra, Cucura, e de seu retorno ao ponto de origem.

Inicialmente há a divisão política evidente em dois planos: o mundo comum de Cravo Branco, onde vigora uma organização social do modo como o homem ocidental contemporâneo a compreende; e o mundo encantado de Cucura, no qual tudo indica haver uma forma de vida ideal, baseada em preceitos desconhecidos daqueles praticados pela razão humana.

Sob a ótica da psicologia, pode-se associar a cidade comum ao plano racional da consciência e a cidade mágica, ao lado instintivo da psique. Entre as duas cidades, há a floresta, que, para os psicanalistas, simboliza o inconsciente ${ }^{124}$. Por sua obscuridade e seu enraizamento profundo, exprime tudo aquilo que permanece abaixo do limiar da consciência. Representa-se, portanto, no espaço narrativo o distanciamento entre o ego, centro da consciência (uma vez que um objeto só é consciente quando o eu o conhece), e as possibilidades intuitivas das personagens de aquisição de conhecimentos.

Os conteúdos inconscientes só podem ser percebidos em algum momento de intuição ou por um processo de intensa reflexão que leve o indivíduo a entrar de alguma forma em contato com eles. Para estabelecer esse contato, além das técnicas de associação entre sonhos e conteúdos conscientes, Jung criou também um método ao qual deu o nome de imaginação ativa ${ }^{125}$. Trata-se de provocar por meio da concentração intencional uma seqüência de fantasias cujo valor, para a psicologia analítica, é similar ao das imagens oníricas.

Para Jung ${ }^{126}$, existem quatro formas por meio das quais a consciência se orienta com relação ao mundo dos fenômenos.

A sensação (isto é, a percepção sensorial) nos diz que alguma coisa existe; o pensamento mostra-nos o que é esta coisa; o sentimento revela se ela é agradável ou não; e a intuição dir-nos-á de onde vem e para onde vai.

${ }^{124}$ CHEVALIER, Jean e GHEERBRANT, Alain. Dicionário de símbolos: mitos, sonhos, costumes, gestos, formas, figures, cores, números. Trad. Vera da Costa e Silva, Raul de Sá Barbosa, Ângela Melim, Lúcia Melim. Rio de Janeiro, José Olympio, 1988, p. 439.

125 JUNG, Carl Gustav. Os arquétipos e o inconsciente coletivo. Trad. Maria Luiza Appy e Dora Mariana R. Ferreira da Silva. Petrópolis, Vozes, 2000, p. 59.

126 JUNG, Carl Gustav. "Chegando ao inconsciente". In: JUNG, Carl Gustav et. alii. O homem e seus símbolos. Trad. Maria Lúcia Pinho. 4.ed., Rio de Janeiro, s/d., p. 61. 
O povo de Cravo Branco, antes de saber da existência do ouro escondido sob a floresta, cultivava flores. Embora cada flor possua, pelo menos secundariamente, um significado próprio, de modo geral, a flor é o símbolo do princípio passivo. "O cálice da flor, tal como a taça, é o receptáculo da Atividade celeste." ${ }^{127}$ Percebe-se, pois, tratar-se, em princípio, de uma comunidade com potencial para viver integrada à natureza. No entanto, desde que o "último índio" havia falado sobre o rico minério, a ambição material levou as pessoas a abandonarem os jardins. Depreende-se, daí, que a passividade de Cravo Branco era apenas uma potencialidade, verificada nos momentos em que, por algum motivo, permaneciam latentes os ímpetos gananciosos de seus habitantes. A referência ao último índio já é sinal do caráter destruidor e predatório dessa civilização que, como se pode inferir da narrativa, erigiu-se sobre o massacre de outra cultura.

Por meio do índio, a população da cidade comum desenvolve a sensação da presença do ouro. Esse conhecimento permanece no plano da percepção sensorial enquanto não se tem certeza da existência do metal e nem informação exata de onde ele se encontra. Já o pensamento, baseado na experiência, pré-avalia as características e as qualidades do rico minério, enquanto que o sentimento revela o valor subjetivo do ouro e o prazer que ele proporciona. Falta, no entanto, ao povo da cidade comum a intuição a respeito do papel que o ouro desempenha no plano maior do equilíbrio ambiental.

O contrário ocorre na cidade mágica, ao Norte. Em Cucura, construída de pedras, ainda reinavam os mesmos reis, desde antes do primeiro índio ali chegar. "Em Cucura, nada nem ninguém acaba" ${ }^{128}$, pensava Casemiro. A idéia da personagem leva à conjectura de que a civilização de Cucura seja anterior aos ameríndios, isto é, originária de um tempo indeterminado, desconhecido, a-histórico. Do ponto de vista mítico, é possível compreender Cucura como o referente arquetípico de Cravo Branco. Ao abordar os arquétipos de cidade, Eliade ${ }^{129}$ relata:

As cidades também têm protótipos divinos. Todas as cidades babilônicas tinham seus arquétipos nas constelações [...]. Não só

${ }^{127}$ CHEVALIER, Jean e GHEERBRANT, Alain. Dicionário de símbolos: mitos, sonhos, costumes, gestos, formas, figures, cores, números. Trad. Vera da Costa e Silva, Raul de Sá Barbosa, Ângela Melim, Lúcia Melim. Rio de Janeiro, José Olympio, 1988, p. 437.

${ }^{128}$ O relógio do mundo, p. 6.

${ }^{129}$ ELIADE, Mircea. Mito do eterno retorno. Trad. José Antonio Ceschin. São Paulo, Mercuryo, 1992, pp. 20-1. 
existe um modelo que precede a arquitetura terrena, mas o modelo também se encontra situado numa região ideal (celestial) da eternidade. [...]

Assim, o mundo que nos rodeia, o mundo no qual são sentidas a presença e a ação do homem - as montanhas que ele escala, as regiões povoadas e cultivadas, os rios navegáveis, as cidades ${ }^{130}$, os santuários tudo isso tem um arquétipo extraterreno, seja ele concebido como um plano, como uma forma, ou pura e simplesmente como uma "cópia", que existe em um nível cósmico mais elevado.

Sobre as organizações sociais que teriam existido no Brasil antes das nações indígenas aqui encontradas pelos colonizadores portugueses, informações chegam até hoje por meio da arte rupestre em todo o país. Em território nacional, são mais de 780 sítios arqueológicos que testemunham a presença de povos bem antigos. Entre esses locais, destaca-se o Vale do Peruaçu, em Minas Gerais, cujas pinturas em grutas e rochas os pesquisadores calculam ter de 2.000 a 10.000 anos. Outro sítio de destaque é o da Caverna da Pedra Pintada, na cidade de Monte Alegre, no Pará, descoberta pela norte-americana Anna Roosevelt, em 1996. As pinturas deixadas em paredões e cavernas, em tons avermelhados, foram feitas há aproximadamente 11.200 anos. Retratam plantas, animais e até cenas de um parto. Os desenhos levam a crer que se tratava de um povo com boas noções de biologia. Segundo a pesquisadora, os vestígios encontrados configuram-se como fortes indícios de que vivera na região amazônica uma civilização bastante avançada. ${ }^{131}$

Voltando à Cucura, o fato de ser feita de pedra, cujo valor simbólico será visto mais adiante, remete, na América do Sul, à cidade inca de Machu Picchu, um dos poucos núcleos urbanos pré-colombianos conservados praticamente intactos, construído inteiramente de rocha, com grandes blocos graníticos unidos sem argamassa. Localizada numa das regiões mais elevadas dos Andes, a cerca de $2.400 \mathrm{~m}$ de altitude, no centro-sul do Peru, Machu Picchu foi abandonada por seus habitantes em época indeterminada e ficou escondida pela vegetação durante séculos, até ser descoberta em 1911 por uma expedição cujo chefe era o norteamericano Hiram Bingham, da Universidade de Yale. Como se sabe, a civilização

\footnotetext{
${ }^{130}$ Grifo nosso.

131 "MONTE ALEGRE, a mais antiga morada do homem das Américas". Amazon view. Disponível em: http://www.inteligentesite.com.br/modelos/modelo70/subconteudo.asp?ID=358\&IDSUBLINK=1874 Acesso em: 21 fev. 2007.
} 
inca desenvolveu-se por toda a Cordilheira dos Andes, que abrange ainda os atuais países Chile, Bolívia e Equador. A capital do império era a sagrada cidade de Cuzco, fundada no século XIII, também no Peru. O imperador, conhecido por Sapa Inca, tinha o status de um verdadeiro deus na Terra. A sociedade, extremamente hierarquizada, organizava-se em três grandes classes: nobres (governantes, chefes militares, juízes e sacerdotes), camada média (funcionários públicos e trabalhadores especializados) e classe mais baixa (artesãos e camponeses). ${ }^{132}$ Essa característica, por si só, já justificaria a citação do povo inca. A informação de que eram sempre os mesmos reis que governavam Cucura, somada ao fato de que lá era um lugar onde nada nem ninguém se acabavam, passa a idéia de uma sociedade estruturada em castas, a exemplo de outras formações sociais, tanto antigas quanto contemporâneas, em várias partes do mundo.

Desta forma Cucura parecia levar a vida: escondida da outra civilização, em paz, sem incomodar ninguém, até o dia em que passou a sentir-se ameaçada. Com os homens de Cravo Branco empenhados em devastar o meio ambiente para extrair o ouro, a cidade de pedra viu-se na contingência de se defender, uma vez que dependia do equilíbrio da natureza. A forma de reação consistia simplesmente em espantar e afugentar os predadores, ou seja, os únicos recursos de defesa empregados pela gente da terra encantada objetivavam apenas impedir que os homens comuns atingissem seus objetivos. Eram utilizados tão somente expedientes mágicos, como explosão de bolas de fogo fátuo, que não machucavam as pessoas e tampouco ofendiam a flora e a fauna, ou emissões de vozes ludibriosas, que faziam os destruidores se separem e se perderem no meio da vegetação mais densa, onde era muito frio e escuro. Jamais houve por parte do povo de Cucura uma atitude de assalto.

Também a vegetação, como se dotada de vontade própria, reagia no sentido de barrar a ação dos gananciosos. Quanto mais os homens cortavam ou incendiavam as matas, mais árvores cresciam, com mais vigor, sempre maiores e mais juntas. Entre elas, enroscavam-se cipós, formando um emaranhado dificílimo de ser transposto. Como a ave mitológica fênix, que ressuscita depois de ter sido queimada na fogueira, a floresta renascia das próprias cinzas, tentando conter a

132 "HISTÓRIA dos Incas". Sua pesquisa.com Disponível em:

http://www.suapesquisa.com/pesquisa/incas.htm. Acesso em: 21 fev. 2007. 
ação dos exploradores. Assustados, muitos deles fugiam de Cravo Branco, retiravam-se ainda mais para o Sul, como fora o caso dos irmãos de Casemiro.

Como se nota, há uma evidente estrutura narrativa que se apóia na divisão maniqueísta existente entre bem e mal, representada por duas formas diferentes de organização comunitária. Associada aos valores negativos do mal está Cravo Branco, cidade dita comum de onde partem os predadores, enquanto Cucura é qualificada com os valores positivos do bem. É a civilização mágica que se demonstra interessada na preservação ambiental. A personagem principal, o menino Casemiro, é originário de uma cultura que vê na exploração desenfreada da natureza o meio prático de satisfazer seus desejos de consumo. Seu pai, o capitão Cornélio Correia, de natureza irascível, obstinava-se a vencer o bloqueio defensivo de Cucura, porém de forma um tanto quanto covarde. Jamais se determinara a enfrentar a luta pessoalmente. Ao contrário, mandava os filhos um após o outro lutarem contra a floresta. Eram 12 os filhos do capitão, sendo Casemiro o mais novo.

O número 12 simboliza o universo no seu curso cíclico espaço-temporal, bem como na sua complexidade interna, como esclarecem Chevalier e Gheerbrant ${ }^{133}$.

[...] O duodenário que caracteriza o ano e o Zodíaco representa também a multiplicação dos quatro elementos, terra, água, ar, fogo, pelos três princípios alquímicos: enxofre, sal, mercúrio; ou, ainda, pelos três estados de cada elemento em suas sucessivas fases de evolução, culminação e involução. [...] A importância desse número é facilmente compreensível. Para os escritores bíblicos é o número de eleição, o do povo de Deus, da Igreja: Israel (Jacó) tinha 12 filhos, ancestrais epônimos das 12 tribos do povo judeu (Gênesis, 35, 23 s.). A árvore da vida tinha 12 frutos; os sacerdotes, 12 jóias. Quando Jesus escolheu 12 discípulos proclamou abertamente sua pretensão de eleger, em nome de Deus, um povo novo (Mateus, 10, $1 \mathrm{~s}$. e paralelos). A Jerusalém celeste tem 12 portas assinaladas com os nomes das tribos de Israel (Apocalipse, 21, 12), e sua muralha, 12 carreiras horizontais de pedra em nome dos 12 apóstolos. A Mulher vestida com o Sol (Apocalipse, 12, 2) tinha sobre a cabeça uma coroa de 12 estrelas. Quanto aos fiéis do fim dos tempos, são 144.000, 12.000 de cada uma das 12 tribos de Israel (Apocalipse, 7, 4-8; $14,1)$.

${ }^{133}$ CHEVALIER, Jean e GHEERBRANT, Alain. Dicionário de símbolos: mitos, sonhos, costumes, gestos, formas, figures, cores, números. Trad. Vera da Costa e Silva, Raul de Sá Barbosa, Ângela Melim, Lúcia Melim. Rio de Janeiro, José Olympio, 1988, p. 348. 
Da mesma forma, a Cidade futura, em ouro fino, além de repousar sobre 12 alicerces, cada um com o nome de um apóstolo do Cordeiro (Apocalipse, 21, 14), constitui-se em um cubo, de que cada face mede 12.000 estádios. E a muralha, de jaspe, tem 144 côvados. Esse número simbólico de 12.000 multiplica por 1.000 (símbolo de multidão) o número de Israel (12), que é o do antigo povo eleito e o do novo. Quanto ao número dos fiéis, 144.000 , o quadrado de 12 multiplicado por 1.000 simboliza a multitude dos fiéis do Cristo.

Explica-se a extensa citação pelo fato de os 12 filhos de Cornélio e Camélia representarem na narrativa simultaneamente 0 início e o fim, seguido de ressurreição da própria humanidade. O significado pode ser depreendido a partir das referências bíblicas ao número 12 presentes tanto no Gênesis quanto no Apocalipse. O 12 é, em definitivo, e sempre, o número de uma realização. Assinala o fim de um ciclo involutivo, seguido pela morte, tomada no sentido de renascimento.

Ao tratar dos temas da escatologia e da cosmogonia, Eliade ${ }^{134}$ revela como os povos primitivos compreendiam a natureza dos ciclos cósmicos, por meio da seguinte idéia: "para que algo de verdadeiramente novo possa ter início, é preciso que os restos e as ruínas do velho ciclo sejam completamente destruídos". Informa ainda Eliade ${ }^{135}$ :

[...] Os mitos do Fim do Mundo certamente desempenharam um importante papel na história da humanidade. Eles colocaram em evidência a "mobilidade" da "origem": efetivamente, a partir de um certo momento, a origem não se encontra mais apenas num passado mítico, mas também num futuro fabuloso. [...]

Numa fórmula sumária, poder-se-ia dizer que, para os primitivos, o Fim do Mundo já ocorreu, embora deva reproduzir-se num futuro mais ou menos distante. Com efeito, os mitos de cataclismos cósmicos são extremamente difundidos. Eles contam como o Mundo foi destruído e a humanidade aniquilada, com exceção de um casal ou de alguns sobreviventes.

A idéia de término de ciclo, de fim dos tempos, em O relógio do mundo, é marcada, entre outros fatores, pelo fato de os 12 rapazes apresentarem

${ }^{134}$ ELIADE, Mircea. Mito e realidade. Trad. Pola Civelli. 6.ed., São Paulo, Perspectiva, 2002, p. 51.

${ }^{135}$ Idem, ibidem, pp. 52-3 
desenvolvimento físico decrescente proporcional à idade, de modo que cada irmão permanecesse sempre um tanto menor do que o outro. A representação sugere o estiolamento, a debilidade progressiva da raça, o processo de involução, contextualmente causados pela destruição do meio ambiente. A idéia é confirmada quando se fica sabendo que Casemiro, o último filho, quase não havia crescido. Permanecia magro, pálido, sem cor. No plano coletivo, conota-se o esfacelamento da civilização de Cravo Branco por meio da dispersão familiar, uma vez que os 11 primeiros filhos do capitão não se predispuseram a seguir as ordens do pai. Ao contrário de seguirem rumo Norte, desafiando as forças de Cucura e da natureza, deslocaram-se mais para o Sul junto com outros moradores, e jamais retornaram. Conta o narrador:

[...] a população ia só diminuindo. A cidade envelhecia, as casas se tornando bolorentas, úmidas, pois de um lado inteiro as árvores barravam a luz.

- Essa gente amaldiçoada não vai conseguir nos vencer! - o capitão bradava na varanda para a capitã, que Ihe cerzia as meias.

Camélia Correia não dizia nada. Havia muitos anos que não se preocupava nem mesmo em ouvir o marido. Ninguém faria com que ela se distraísse daquela tarefa de fechar os buracos da meia. ${ }^{136}$

Como se percebe no trecho acima, Camélia Correia, a mãe, nunca tivera voz ativa para impedir os mandos e desmandos do marido. Resignada a uma posição subalterna jamais retrucava os gritos de Cornélio. Descreve-se, assim, a decadência de uma família, e por extensão de um regime econômico, ainda com resquícios do sistema patriarcal, nos moldes como se formou no Brasil à época da colonização, em que a mulher dava à luz numerosa prole e não tinha influência alguma com relação aos desígnios do patriarca. Essa estrutura social é confirmada até mesmo pelo fato de o narrador referir-se ao pai como o capitão, que remete a coronel, alcunha dada aos antigos senhores de engenho ${ }^{137}$ nas antigas fazendas coloniais, onde, ao pater familias, subordinavam-se todos os demais habitantes: escravos,

${ }_{136}^{136}$ O relógio do mundo, p. 6.

${ }^{137}$ A título de curiosidade, a personagem, como já se disse, chama Cornélio, que em Latim significa duro como chifre. O nome remete ao Coronel Cornélio Procópio de Araújo Carvalho, figura de destaque no Império, durante o século XVIII, que deu nome à cidade de Cornélio Procópio, localizada ao Norte do Paraná, região Sul do Brasil. 
empregados, esposa, amantes, filhos e até mesmo o capelão. Como se observa em O relógio do mundo, por exemplo, os filhos mostram-se incapazes de contrariar o pai. Quando insatisfeitos, preferem a fuga ao confronto. A essa conformação política, atribui Freyre ${ }^{138}$ o sadismo e o gosto de mando característicos de todo brasileiro nascido ou criado em casa-grande. Ao tratar especificamente da situação da mulher com vistas naquele contexto, o sociólogo conjectura:

Resultado da ação persistente desse sadismo, de conquistador sobre conquistado, de senhor sobre escravo, parece-nos o fato, ligado naturalmente à circunstância econômica da nossa formação patriarcal, da mulher ser tantas vezes no Brasil vítima inerme do domínio ou do abuso do homem, criatura reprimida sexual e socialmente dentro da sombra do pai ou do marido. ${ }^{139}$

A despeito do avanço do processo de emancipação feminina, verificado a partir de meados do século XX, Camélia ${ }^{140}$, apesar de ser chamada a capitã, representa a mãe de família tradicional, servidora do lar, sem vontade própria, que encontra refúgio em uma espécie de introspecção libertária, isto é, no desenvolvimento de rica vida interior, de forte religiosidade ou de ligação com o lado mágico-intuitivo da existência. Casemiro havia herdado alguns traços da natureza da mãe, pois também não dava ouvidos às crises nervosas do pai. Alienava-se a tudo que era externo ao entreter-se com os cuidados do jardim. Gostava de cultivar cravos brancos, uma prática que, de certa forma, o relacionava com a essência primordial do povo de sua cidade.

Segundo Jung ${ }^{141}$, já na Idade Média, muito antes de os filósofos terem demonstrado que os seres humanos, devido a sua estrutura glandular, apresentam em si os elementos masculino e feminino, se dizia que "todo homem traz dentro de si uma mulher". Na psicologia analítica, esse elemento feminino que há em todo

${ }^{138}$ FREYRE, Gilberto. Casa grande e senzala: formação da família brasileira sob o regime da economia patriarcal. 49. ed., rev., São Paulo, Global, 2004, p. 114.

139 Idem, ibidem.

${ }^{140}$ Vale a lembrança de que o nome Camélia lembra Amélia, personagem-símbolo da mulher totalmente passiva na Música Popular Brasileira, eternizada na canção Ai que saudade da Amélia, de Ataulpho Alves e Mário Lago. Diz a letra: [...] Ai meu Deus, que saudade da Amélia / Aquilo sim é que era mulher. / Às vezes passava fome ao meu lado / $E$ achava bonito não ter o que comer / $E$ quando me via contrariado /Dizia: Meu filho, que se há de fazer. / Amélia não tinha a menor vaidade / Amélia é que era a mulher de verdade [...].

141 JUNG, Carl Gustav. "Chegando ao inconsciente". In: JUNG, Carl Gustav et. alii. O homem e seus símbolos. Trad. Maria Lúcia Pinho. 4.ed., Rio de Janeiro, s/d., p. 31. 
homem é chamado anima, e, nas suas manifestações individuais revela, em geral, um caráter determinado pela mãe do indivíduo ou, ainda, por outras mulheres com as quais ele conviveu desde o nascimento. Explica Franz ${ }^{142}$ :

Anima é a personificação de todas as tendências psicológicas femininas na psique do homem - os humores e sentimentos instáveis, as intuições proféticas, a receptividade ao irracional, a capacidade de amar, a sensibilidade à natureza e, por fim, mas nem por isso menos importante, o relacionamento com o inconsciente.

Jung ${ }^{143}$ esclarece que não é apenas da mãe pessoal que provêm todas as influências sobre a psique infantil, mas é muito mais o arquétipo materno projetado na mãe que outorga à mesma um caráter mitológico e, com isso, lhe confere autoridade e até mesmo numinosidade. Os efeitos da mãe sobre os filhos devem ser divididos em dois grupos: os que correspondem à qualidade característica ou atitudes realmente existentes na mãe pessoal e os que só aparentemente possuem tais características, uma vez que se trata de projeções de tipo fantasioso (quer dizer, arquetípico) por parte da criança.

Como todo arquétipo, o materno também possui uma variedade incalculável de aspectos. Menciono apenas algumas das formas mais características: a própria mãe e a avó; a madrasta e a sogra; uma mulher qualquer com a qual nos relacionamos, bem como a ama-de-leite ou amaseca, a antepassada e a mulher branca; no sentido da transferência mais elevada, a deusa, especialmente a mãe de Deus, a Virgem (enquanto mãe rejuvenescida, por exemplo, Deméter e Core), Sofia (enquanto mãe que também é amada), eventualmente também o tipo Cibele-Átis, ou enquanto filha-amada (mãe rejuvenescida); a meta da nostalgia da salvação (Paraíso, Reino de Deus, Jerusalém Celeste); em sentido mais amplo, a Igreja, a Universidade, a cidade ou país, o Céu, a Terra, a floresta, o mar e as águas quietas; a matéria, o mundo subterrâneo e a Lua; em sentido mais restrito, como o lugar do nascimento ou da concepção, a terra arada, o jardim, o rochedo, a gruta, a árvore, a fonte, o poço profundo, a pia batismal, a flor como recipiente (rosa e lótus); como círculo mágico (a

${ }^{142}$ FRANZ, Marie-Louise von. "O processo de individuação". In: JUNG, Carl Gustav et. alii. O homem e seus símbolos. Trad. Maria Lúcia Pinho. 4.ed., Rio de Janeiro, s/d., p. 176.

143 JUNG, Carl Gustav. Os arquétipos e o inconsciente coletivo. Trad. Maria Luíza Appy e Dora Mariana R. Ferreira da Silva. Petrópolis, Vozes, 2000, p. 93. 
mandala como padma) ou como cornucópia; em sentido mais restrito ainda, o útero, qualquer forma oca (por exemplo, a porca do parafuso); a yoni; o forno, o caldeirão; enquanto animal, a vaca, o coelho e qualquer animal útil em geral.

Esta enumeração não pretende ser completa. Ela apenas indica os traços essenciais do complexo materno. ${ }^{144}$

Da lista apresentada por Jung, nota-se que, em $O$ relógio do mundo, o arquétipo materno é reiterado por meio de diferentes símbolos: a própria Camélia, mãe pessoal; o lugar de nascimento; as cidades (Cravo Branco e Cucura); o jardim e as flores (cravos brancos) que Casemiro cultiva; a floresta, naquilo que o conteúdo do inconsciente contém da anima; o poço profundo, a gruta e o mundo subterrâneo, representados pela caverna na qual o garoto cai, conforme será visto. Todos esses símbolos podem ter para o instinto do indivíduo um sentido positivo ou negativo, a depender do tipo de projeção.

Casemiro não só se espelha na mãe para estabelecer relacionamento com o pai, como também carrega algo da sensibilidade dela. Além disso, no decorrer do processo de amadurecimento, reagirá a situações a partir das características da anima que traz introjetada na psique. Terá também de resolver determinados conflitos gerados justamente por essa presença interior, como é demonstrado no decorrer da análise. Mas, por ora, deve-se voltar a compreender o papel da capitã. É uma espécie de sexto sentido de Camélia que faz com que ela perceba a presença de uma borboleta cor de prata voejando o filho e intua tratar-se de um inseto mensageiro; se de boa ou má sorte, não tem certeza. O teor da mensagem Ihe será revelado apenas durante o sonho.

Ao cair da noite, naquele dia, o pio insistente de uma coruja fez-se ouvir rondando a residência dos Correia. O capitão entendia ser aquele um sinal de mau agouro, pois é senso comum acreditar-se que a coruja anuncia a morte quando sobrevoa a casa de pessoas enfermas e avisa desgraças pelas simples audição de seu canto lúgubre. ${ }^{145}$ A capitã, por sua vez, não pensava assim:

${ }^{144}$ Idem, ibidem, pp. 91-2.

${ }^{145}$ CASCUDO, Luís da Câmara. Dicionário do folclore brasileiro. 11. ed., rev., atual. e ilust., São Paulo, Global, 2002, p. 164. 
—É bobagem caçar esse bicho. Não há nenhum agouro - disse Camélia, lembrando que não tinha nenhum doente em casa. ${ }^{146}$

Segundo Chevalier e Gheerbrant ${ }^{147}$, a coruja relaciona-se com a Lua, uma vez que não consegue suportar a luz do Sol. Nesse particular, opõe-se à águia, que recebe essa luz com os olhos abertos. Citando Guénon ${ }^{148}$, os autores observam que se pode ver nesse aspecto, assim como na relação com Atena-Minerva, o símbolo do conhecimento racional - percepção da luz por reflexo, uma vez que a Lua apenas reflete a luminosidade do Sol - em oposição ao conhecimento intuitivo, representado pela percepção direta da luz solar.

É por meio da intuição que Camélia percebe a inocência da coruja. É também o conhecimento intuitivo revelado pelo sonho que permite à mãe de Casemiro saber antecipadamente que era chegada hora da partida do último filho. A capacidade que os seres humanos têm de pressentirem a iminência de certos acontecimentos é explicada por Jung ${ }^{149}$ pelo fato de que, assim como o conteúdo consciente pode se desvanecer no inconsciente, novos conteúdos podem surgir. Pode-se ter a impressão de que "há alguma coisa no ar". Segundo o psiquiatra, muitos artistas, filósofos e mesmo cientistas devem suas melhores idéias a inspirações nascidas do inconsciente. Conscientemente, Camélia jamais acreditara que Casemiro fosse mandado à floresta pelo capitão. Isso porque o menino era franzino, raquítico, mal conseguia levantar a espingarda ou o machado. Tanto pensava assim que, no contexto do sonho, vê o menino encolher ao extremo. Pela qualidade simbólica das imagens oníricas, vale reproduzir o trecho.

Logo o dia amanhecia de um jeito diferente. Não trazia uma luz amarela, mas esbranquiçada. Não era o sol que nascia, mas uma segunda lua, sem que a primeira tivesse partido. Tudo ficava então meio velado e atravessado de sombras. A capitã, assim que levantou, foi buscar uma vassoura. Pra varrer as folhas e a poeira que entravam pelos quartos. Foi varrendo para a varanda. E aí ouviu um gemido:

- Não me varra, minha mãe.

${ }^{146}$ O relógio do mundo, p. 9

${ }^{147}$ CHEVALIER, Jean e GHEERBRANT, Alain. Dicionário de símbolos: mitos, sonhos, costumes, gestos, formas, figures, cores, números. Trad. Vera da Costa e Silva, Raul de Sá Barbosa, Ângela Melim, Lúcia Melim. Rio de Janeiro, José Olympio, 1988, p. 293.

${ }_{148}$ GUÉNON, R. Symboles fondamentaux de la Science Sacrée, Paris, 1962.

149 JUNG, Carl Gustav. "Chegando ao inconsciente". In: JUNG, Carl Gustav et. alii. O homem e seus símbolos. Trad. Maria Lúcia Pinho. 4.ed., Rio de Janeiro, s/d., p. 37. 
Camélia se abaixou e viu uma folha se mexendo. Segurou pela beiradinha e a levantou do chão. Quem estava embaixo, tão pequeno que cabia na palma de sua mão, era o Casemiro. ${ }^{150}$

Camélia guardou o filho no bolso do avental e continuou varrendo. $\mathrm{Na}$ seqüência, quase pisou em uma borboleta cujas asas tinham manchas prateadas, a mesma da cor da segunda lua que subia no céu. É a borboleta quem lhe diz que Casemiro deveria atravessar a mata. A mulher argumenta que não seria possível, pois o menino mal podia levantar a espingarda ou o machado, principalmente depois de haver diminuído tanto. Mas a borboleta mantém-se irredutível, objetando que a floresta só poderia ser enfrentada por alguém bem pequeno.

Como foi visto, a floresta representa o inconsciente. Nos contos de fadas, por exemplo, os terrores representados pela mata fechada simbolizam o medo das revelações do inconsciente. A relação da vegetação densa que aparece na maioria dos contos maravilhosos com a floresta que figura nos ritos de passagem característicos das sociedades ditas primitivas, isto é, de organizações sociais hoje desaparecidas, é muito estreita. O rito de iniciação sempre ocorria em uma floresta. No mundo inteiro essa é uma característica constante. Propp ${ }^{151}$ pondera os motivos dessa prática. Segundo ele, pode-se supor que a floresta oferecia a possibilidade de se cumprir o rito em segredo, que ela ocultava o mistério. Mas, de acordo com o material recolhido pelo pesquisador russo, a floresta cerca o outro reino, ou seja, o caminho para o outro mundo passa pela floresta, relembrando aqui que a celebração da entrada na vida adulta era conduzida por meio de um verdadeiro ritual de morte e renascimento. Assim, "a floresta do conto reflete a lembrança da floresta como o local do rito e como entrada para o reino dos mortos". 152

Uma das mensagens que se apreende do sonho de Camélia é a de que era o momento de Casemiro deixar de ser criança, de enfrentar o inconsciente, de resolver os questionamentos propostos pela anima, ainda fortemente marcado pela figura materna. Como se percebe, a tendência da capitã era a de subestimar a capacidade do filho mais novo, de julgá-lo incapaz de enfrentar os perigos da floresta. Como mãe protetora, imaginava poder preservar o caçula da missão

\footnotetext{
${ }^{150}$ O relógio do mundo, p. 10.

151 PROPP, Vladímir. As raízes históricas do conto maravilhoso. Trad. Rosemary Costhek Abílio e Paulo Bezerra. 2.ed., São Paulo, Martins Fontes, 2002, p. 56.

152 Idem, ibidem, p. 57.
} 
imposta pelo marido aos demais filhos, de modo a retê-lo perto de si. Que o complexo materno ainda atuava soberano na psique do filho mais novo, é fato percebido pelo modo como o menino rejeita o modelo paterno de atuação ante as forças de Cucura e dedica-se a cuidar do jardim e ao cultivo de cravos brancos.

Para a psicologia de linha junguiana, o complexo materno revela-se no filho homem por meio de características comportamentais que denotam dependência da mãe. Durante o processo de desenvolvimento psíquico, se o indivíduo fica preso a esse complexo por período prolongado, ou seja, além da idade em que normalmente se requer de fato proteção e cuidados maternos, terá tendência a identificar-se apenas com uma das polaridades do arquétipo puer-senex, qual seja, a do puer aeternus, que significa juventude eterna. Franz ${ }^{153}$ explica:

Em geral, o homem que se identifica com o arquétipo do puer aeternus permanece durante muito tempo como adolescente, isto é, todas aquelas características que são normais em um jovem de dezessete ou dezoito anos continuam na vida adulta, juntamente com uma grande dependência da mãe, na maioria dos casos.

Os efeitos do complexo materno na psique masculina são variados. Entre eles, Franz ${ }^{154}$ trata de forma pormenorizada o homossexualismo e o donjuanismo ${ }^{155}$. Ao tratar do assunto, Jung ${ }^{156}$ esclarece que o complexo materno pode ser responsável pelo desenvolvimento do bom gosto e da estética; de riqueza de sentimento religioso; de dons para a educação, aperfeiçoados pela intuição e tato femininos ou espírito histórico conservador (no bom sentido), que preserva cuidadosamente os valores do passado, entre outros. Viu-se como Casemiro mantinha-se sintonizado com a tradição de seu povo por meio do plantio de cravos brancos.

${ }^{153}$ FRANZ, Marie-Louise von. 'Puer aeternus': a luta do adulto contra o paraíso da infância. Trad. Jane Maria Corrêa. São Paulo, Paulus, 1992, p. 9.

154 Idem, ibidem.

${ }^{155} \mathrm{O}$ termo é derivado de Don Juan, personagem literário tido como símbolo da libertinagem. O primeiro romance com referência à personagem foi a obra El Burlador de Sevilla, de 1630, do dramaturgo espanhol Tirso de Molina. Fonte: BALLONE G.J. "Síndrome de Don Juan e o hábito de 'ficar"'. PsiqWeb Psiquiatria Geral. Campinas, dez. 2004. Disponível em: http://www.psiqweb.med.br/sexo/donjuan.html. Acesso em: 4 mar. 2007.

156 JUNG, Carl Gustav. Os arquétipos e o inconsciente coletivo. Trad. Maria Luíza Appy e Dora Mariana R. Ferreira da Silva. Petrópolis, Vozes, 2000, p. 96. 
O estudo do arquétipo puer-senex foi mais bem desenvolvido por Hillman ${ }^{157}$, segundo quem o problema do comportamento exclusivamente puer não estaria relacionado apenas com o complexo materno. Para ele, atitudes pueris não são exclusividades da juventude, assim como qualidades senis não estão reservadas para a velhice. Uma vez que puer e senex são polaridades do mesmo arquétipo, um e outro podem aparecer em muitos estágios e fases da vida de uma pessoa, como decorrentes de, ou mesmo influenciando, qualquer complexo. Argumenta Hillman ${ }^{158}$ :

Vivemos, é claro, numa era das mães, porque a cultura é secular e o comum dos mortais deve carregar as cargas arquetípicas sem o auxílio dos deuses [referência à mitologia]. As mães têm de sustentar nossa subsistência, quando elas mesmas não têm sustentação alguma; têm de ser como deusas, como tudo ao extremo; e nos sacrificam à sua frustração, enquanto nós, à medida que nos tornamos pais e mães, sacrificamos nossos filhos à mesma civilização.

O modo de "resolver o complexo materno" seria não propriamente desligar-me de minha mãe, mas romper o antagonismo que me faz heróico e, a ela, negativa. "Resolver o complexo materno do puer" significa remover o fenômeno puer da mãe, não mais concebendo os problemas do puer como causados pela mãe nem vinculados a ela. (Pois, em nossa civilização, o que é que não se pode atribuir à mãe?) Em vez de separar homem e mãe, devemos antes separar a necessidade arquetípica de associação dos dois e considerar a fenomenologia do puer como uma coisa em si.

Polêmicas à parte, o fato é que, para que possa dar livre curso ao processo rumo à maturidade, Casemiro será obrigado a abdicar das proteções, sejam elas maternas ou de qualquer origem. Em outras palavras, o garoto deverá seguir ao encontro de seus conteúdos inconscientes, representado pela entrada na floresta. Quanto à mãe, quer ela queira ou não, terá de aceitar a partida do filho. É o que lhe diz o sonho, entre outros recados. Há de se notar que, no sonho, o dia amanheceu em luz esbranquiçada. Em vez do Sol, apareceu uma segunda lua, sem que a

${ }^{157}$ HILLMAN, James. O livro do 'puer': ensaios sobre o arquétipo do 'puer aeternus'. Trad. Gustavo Barcellos. São Paulo, Paulus, 1998.

${ }^{158}$ Idem, ibidem, p. 91. 
primeira tivesse ido embora. De acordo com Chevalier e Gheerbrant ${ }^{159}$, a Lua simboliza o princípio passivo, mas fecundo, a noite, a umidade, o subconsciente, a imaginação, o psiquismo, o sonho, a receptividade, a mulher e tudo que é instável, transitório e influenciável, por analogia com seu papel refletor da luz solar. Nesses sentidos, a Lua remete à própria Camélia, mulher, mãe, passiva, imaginativa, sonhadora, influenciável, receptiva às decisões do capitão. Mas há outro fator a ser considerado, que é o dos símbolos da Lua e da coruja estarem relacionados. Recorre-se novamente a Chevalier e Gheerbrant ${ }^{160}$ :

A Lua, astro das noites, evoca metaforicamente a beleza e também a luz na imensidade tenebrosa. Mas como essa luz não é mais que um reflexo da luz do Sol, a Lua é apenas símbolo do conhecimento por reflexo, isto é, do conhecimento teórico, conceptual, racional; é nesse ponto que é ligada ao simbolismo da coruja.

No sonho de Camélia, a primeira lua refere-se obviamente ao satélite da Terra, que, mesmo ao amanhecer, não havia desaparecido. Já a segunda indubitavelmente representa a coruja. A associação é confirmada quando se fica sabendo que, na manhã subseqüente à noite do sonho, a ave reaparece, dessa vez piando de dia. Sob esse aspecto, o sonho é premonitório, uma vez que era esse o sinal que faltava para o capitão decidir enviar seu último filho à luta. No contexto mais amplo, no entanto, as imagens oníricas da capitã sugerem ainda outras interpretações. Se a Lua (e também a coruja) representa o conhecimento por reflexo, aquele que se pode obter por meios racionais, a presença no firmamento de duas luas no lugar do Sol reforça a idéia de que em Cravo Branco a razão humana não faz mais nenhum tipo de concessão ao conhecimento intuitivo, representado pela luz solar. Se a coruja pode aparecer de dia é porque a luz do Sol em Cravo Branco já é tão fraca que não incomoda o pássaro. Metaforicamente, a narrativa remete a uma sociedade que, por ter declinado da intuição, paga o preço do desequilíbrio ambiental. Trata-se de uma civilização que não se percebe intuitivamente como sendo parte do todo que é a natureza.

${ }^{159}$ CHEVALIER, Jean e GHEERBRANT, Alain. Dicionário de símbolos: mitos, sonhos, costumes, gestos, formas, figures, cores, números. Trad. Vera da Costa e Silva, Raul de Sá Barbosa, Ângela Melim, Lúcia Melim. Rio de Janeiro, José Olympio, 1988, pp. 562-6.

${ }^{160}$ Idem, ibidem. 
Ainda referentemente ao sonho, outros sinais devem ser observados. É a borboleta prateada quem informa à capitã sobre a iminente partida de Casemiro. A borboleta é símbolo de ligeireza sutil, representa espírito viajante. Por um lado, sua presença anuncia uma visita ou a morte de uma pessoa próxima, por outro, em virtude de suas metamorfoses, está associada ao renascimento: a crisálida é o ovo que contém a potencialidade do ser; a borboleta que sai dele é um símbolo de ressurreição, tanto para diversas culturas tradicionais quanto para a psicanálise moderna. ${ }^{161} \mathrm{O}$ fato de a borboleta ser prateada remete novamente à Lua. Tradicionalmente, por oposição ao ouro, que é princípio ativo, macho, solar, diurno, ígneo, a prata é princípio passivo, feminino, lunar, aquoso, frio. Branca e luminosa, a prata é igualmente símbolo de toda espécie de pureza. Chevalier e Gheerbrant ${ }^{162}$ citam Gevaert ${ }^{163}$ para melhor explicar o sentido da prata:

É a luz pura, tal como é recebida e restituída pela transparência do cristal, na limpidez da água, nos reflexos do espelho, no brilho do diamante; assemelha-se à limpidez de consciência, à pureza de intenção, à fraqueza, à retidão de atos; invoca a fidelidade que de tudo isso resulta.

Em O relógio do mundo, a partir da presença da borboleta prateada, são dois os aspectos a serem considerados. Primeiramente, a simbologia do inseto retoma aquela já inserida por meio da referência aos 12 filhos do capitão, ou seja, a da morte seguida de ressurreição. Já no início da narrativa, em termos coletivos, isto é, da população de Cravo Branco, mais uma vez os índices apontam para o fim de um ciclo, para a escatologia, cuja contrapartida mítica é uma nova cosmogonia. No plano individual do protagonista, alude-se à fase de desenvolvimento psíquico a que Casemiro se encontra. A mensagem que a borboleta transmite à capitã é a de que era chegada a hora de o menino submeter-se ao rito de passagem para a idade adulta, o qual pressupõe morte e ressurreição de conteúdos psíquicos. Em segundo lugar, deve ser notado que os sentidos de pureza de intenção, fraqueza e retidão de atos, inerentes à cor prata da borboleta, relacionam-se ao fato de Casemiro aparecer

\footnotetext{
161 Idem, ibidem, pp.138-9.

162 Idem, ibidem, p. 739.

${ }^{163}$ GEVAERT, Émile. L'Héraldique, son esprit, son langage et ses applications. Bruxelas, 1923.
} 
em tamanho diminuto no sonho da mãe. Como já foi visto, o inseto afirma peremptoriamente: "O mistério dessa floresta só pode conhecer quem é pequeno!". 164

A afirmativa leva à seguinte conjectura: se a floresta é o inconsciente no qual o homem deve "mergulhar" para crescer psicologicamente por meio da aquisição do saber intuitivo, direto, advindo da luz solar, não se limitando ao conhecimento racional-teórico, por reflexo, representado pela Lua, pela coruja e pela cor prata da borboleta, enfim, se o homem deve investigar os conteúdos que surgem do inconsciente, não é com a bravura, a arrogância e a agressividade de quem se sente superior às forças da natureza que deve fazê-lo, mas sim com a humildade de reconhecer-se pequeno diante da grandiosidade do universo e da Criação.

Como se nota, o sonho da capitã em quase tudo se confirma. Ao acordar naquela manhã, Camélia constata que, de fato, não havia duas luas, mas o Sol parecia mais distante e mais frio. Logo se ouviu novamente o piar da coruja, deixando Cornélio ainda mais transtornado. Imediatamente, ele procura pelo filho, que já estava, como de costume, a cuidar do jardim.

— Siga esse bicho aonde for, mas acabe com sua vida agourenta! — trovejava o capitão. ${ }^{165}$

Aos olhos do pai, os cravos pareciam ter crescido exageradamente. Esclarece o narrador:

[...] Como o capitão era inimigo da magia, preferiu não enxergar o que se passava diante de seu nariz. Casemiro tinha acordado um palmo menor. ${ }^{166}$

Trata-se da confirmação de que Casemiro possui as prerrogativas necessárias para postar-se ante o desconhecido com limpidez de consciência, isto é, sem preconceitos, certezas prévias ou pré-julgamentos, diferentemente do que ocorria com o pai. Em outras palavras, o encolhimento do menino mostra que ele é permeável ao fato de que, embora desempenhe papel preponderante, o saber racional não é o único viável e possível. No que tange ao assunto, a mensagem da

${ }_{164}^{164}$ O relógio do mundo, p. 11.

165 Ibidem, p. 13.

${ }^{166}$ Ibidem, p. 13. 
narrativa é tácita: não se deve em hipótese alguma abdicar do conhecimento por reflexo, lunar, consciente, teórico. Ao contrário, ele é importante para chamar a atenção do indivíduo, para alertá-lo a respeito da imprescindibilidade dos conceitos advindos por via direta, intuitiva, solar. Dessa forma, o conhecimento racional, egóico, constitui-se meio de acesso, mas não deve ser compreendido como o todo, o self, sob o risco de cegar para a integralidade psíquica e até mesmo de se autodestruir. (Note-se que Cornélio quer que o filho mate a coruja.) No enredo, a proposição é representada tanto pela ave, que pia como se a evocar Casemiro para o desafio, quanto pela borboleta, que furtivamente o acompanha durante a incursão pela floresta, ambas simbolizando a consciência.

Ante a determinação do capitão, Casemiro sente o impulso para ir. Não censurava de modo algum a ordem do pai. Ao contrário, enxergava na situação uma oportunidade de virar as costas à decadência e às dificuldades de Cravo Branco. Além do mais, a palavra Cucura ecoava forte em sua mente. Talvez por isso em nenhum momento tenha imaginado a possibilidade de desobedecer, nem mesmo de fugir, seguindo o exemplo dos irmãos. Embora entristecesse por separar-se da mãe e do jardim, ouvia intimamente uma espécie de chamado para a aventura. Apenas não estava satisfeito com a segunda parte da missão, que dizia respeito a acabar com a vida da coruja. Quanto a isso, conjeturou ser suficiente afastá-la para bem longe dali.

Em termos psicológicos, pode-se seguramente afirmar que o garoto estava intuitivamente atento aos apelos da psique para que entrasse em contato com os conteúdos de seu inconsciente, ou seja, para que se permitisse explorar aquele vasto mundo desconhecido. Vale também ponderar que todos os símbolos que indicam a iniciativa da personagem - Lua, coruja, borboleta prateada (e mais à frente o sapo, conforme será notado) - , independentemente das referências que fazem ao conhecimento racional, estão relacionados ao princípio feminino. Até mesmo a floresta, que de modo amplo representa o inconsciente, em sentido restrito, significa a mãe. Como se essas figuras não bastassem, soma-se a elas o fato de o aviso da partida do menino ter sido dado antecipadamente por intermédio do sonho da capitã. É a anima, e a necessidade de se harmonizar com ela, que impulsiona Casemiro à ação. É o componente feminino presente na psique do homem que o habilita, a partir da necessidade de resolução do complexo materno, a 
iniciar a busca pelo processo de individuação, enveredando por um caminho no qual não faltarão outras provas, novamente propostas pelo conteúdo do inconsciente.

Chega enfim o momento de o herói partir. Casemiro está tão pequeno, que mal consegue carregar a espingarda. Aparentemente, está tão fraco e franzino, que é chamado pela mãe de Amarelinho. O apelido retoma a idéia de falta de vitalidade, em conseqüência do desequilíbrio ambiental. Como a floresta cresce sempre mais, e mais rapidamente, para defender a própria existência, o desenvolvimento descontrolado da vegetação asfixia a vida em Cravo Branco. Tomando-se a floresta no sentido de mãe, a imagem sugere o perigo que Casemiro corre de sucumbir ao complexo materno. Por meio de uma atitude inconscientemente devoradora, recoberta sobre o falso manto da proteção, Camélia ao apelidar o menino de Amarelinho, a exemplo de muitas mães, obsta de alguma forma o desenvolvimento psicológico do filho. Para Franz ${ }^{167}$, é o animus devorador da mãe que, às vezes, se alimenta da inocência e dos sentimentos mais nobres e devotados do filho. $\mathrm{Na}$ psicologia analítica, animus é a personificação masculina do inconsciente na mulher, correspondente à anima do homem. Nessa relação mãe-filho, para o filho, explica Jung ${ }^{168}$, "a anima oculta-se no poder dominador da mãe e a ligação sentimental com ela dura às vezes a vida inteira, prejudicando gravemente o destino do homem ou, inversamente, animando a sua coragem para os atos mais arrojados."

No caso de Casemiro, enfrentar a floresta significa não se deixar abater pelo domínio afetivo da capitã, alcunha que emerge do animus de Camélia e dos perigos que ele representa. Sob esse aspecto, o papel de Cornélio, ao mandar o filho à captura da coruja, de modo a afastá-lo da mãe, é de importância fundamental. Na hora da partida, o pai quer ainda que o menino leve o machado. Casemiro recusa:

- O machado, não posso! Sou jardineiro e não vou atacar as árvores.

Cornélio, magoado com a objeção do filho, ia chamar Casemiro de idiota, dizer que aquelas árvores não eram árvores normais, mas inimigas. Camélia então interveio:

— Deixe, capitão. Ele não dá conta de carregar... ${ }^{169}$

${ }^{167}$ FRANZ, Marie-Louise von. 'Puer aeternus': a luta do adulto contra o paraíso da infância. Trad. Jane Maria Corrêa. São Paulo, Paulus, 1992, p. 52.

168 JUNG, Carl Gustav. Os arquétipos e o inconsciente coletivo. Trad. Maria Luíza Appy e Dora Mariana R. Ferreira da Silva. Petrópolis, Vozes, 2000, p. 39.

${ }^{169}$ O relógio do mundo, p. 14. 
A interferência da mãe é o último recurso de quem reconhece que é necessário se conformar. No íntimo, Camélia sabe que deve encorajar a independência e o desenvolvimento de Casemiro.

"Como ele é fracote!", ela pensou. Mas se lembrou do recado dado no sonho pela borboleta e conseguiu se acalmar. ${ }^{170}$

Percebe-se na psique de Camélia a função do sonho no sentido de auxiliá-la a transformar o afeto devorador em encorajamento saudável. Por meio das imagens oníricas, a mulher adquire o conhecimento intuitivo de que é melhor deixar o filho seguir o caminho dele. Conforta o coração de mãe a idéia de que uma força superior o protege. Tanto é que, na hora em que Casemiro sumiu atrás da vegetação, ela vislumbrou um brilho prateado seguindo o menino.

Ao pisar no interior da floresta, Casemiro está menor ainda. Depreende-se que o contato com o inconsciente torna o indivíduo pequeno ante a grandiosidade do desconhecido. Essa magnificência dos conteúdos inconscientes é simbolizada no texto pela dimensão das plantas, dos insetos e dos animais.

[...] Tudo ali era maior do que ele podia imaginar. Formigas do tamanho de besouros caminhando sobre cipós larguíssimos. Raízes tortuosamente compridas se espalhavam à sua frente. [...] Mais perto de Casemiro, ao alcance dos olhos, uma borboleta flutuava. Parecia um grande beija-flor. $\mathrm{O}$ barulho das asas tilintava como um metal bem fino. Com tanta coisa surpreendente, para ele era quase normal que ela parecesse de prata. ${ }^{171}$

Depois de um primeiro instante de choro, de medo, de insegurança, Casemiro se predispôs a seguir em frente. Apenas não tinha certeza de qual rumo tomar. Três trilhas abriam-se à sua frente. O simbolismo do número três é amplo e complexo nas mais diversas culturas. De modo geral, "exprime uma ordem intelectual e espiritual, em Deus, no cosmo ou no homem" ${ }^{172}$. Em outras palavras, significa a tríplice manifestação divina: criação, conservação e transformação. Pode representar

${ }^{170}$ Ibidem, p. 14.

171 Ibidem, p. 15.

${ }^{172}$ CHEVALIER, Jean e GHEERBRANT, Alain. Dicionário de símbolos: mitos, sonhos, costumes, gestos, formas, figures, cores, números. Trad. Vera da Costa e Silva, Raul de Sá Barbosa, Ângela Melim, Lúcia Melim. Rio de Janeiro, José Olympio, 1988, p. 899. 
também o desenvolvimento do Universo em sua total harmonia e os três principais ciclos da vida: nascimento, apogeu e morte. O cabalista Egito ${ }^{173}$ escreve:

\begin{abstract}
O matemático e místico Abellio ${ }^{174}$ disse: "Os números 1 e 2 se mantêm fora da manifestação espacial, e sua exclusão se prende, diretamente, à lei fundamental segundo a qual qualquer manifestação exige a trindade e começa por ela."

A manifestação dos números tem muitas peculiaridades. Vejamos a seguinte: Em sentido prático a conscientização numérica começa com o três, mas, mesmo assim, este número ainda não pode representar um sólido, ou seja, algo que tenha uma forma de existência como coisa.

O triângulo é uma figura que só existe no plano e como o universo não é plano conseqüentemente o triângulo é apenas uma idéia de algo conscientizável, mas que inexiste estruturalmente.
\end{abstract}

Isso implica dizer que, antes de algo ser realizado, é preciso idealizar esse algo. Em outros termos, antes da concretização de um determinado plano, será obrigatório defrontar-se com o número três. Nos contos maravilhosos, em que o três surge reiteradamente - três fadas, três gotas de sangue, três lágrimas, três porquinhos, uma determinada ação que se repete três vezes... - o número está associado à dimensão mágica, isto é, fora do espaço real, onde se desenvolvem os enredos, mas sua função simbólica vai além. O três evoca o papel preponderante que desempenha o pensamento mágico para o processo de desenvolvimento do plano das idéias por parte da criança.

No texto em estudo, é a coruja quem indica o rumo a ser seguido. Uma vez que a missão de Casemiro era atingir a ave, o menino seguirá pela trilha na qual ela piar. Mais uma vez tem-se a representação de que é o conhecimento racional, lunar, que deve apontar o caminho para o conhecimento intuitivo, solar, de modo que, sem o primeiro, não se obtém o segundo. Assim, sugere-se novamente que a ampliação da consciência se dá por meio de um processo cujo objetivo é fazer interagir os saberes teórico e instintivo.

${ }^{173}$ EGITO, José Laércio de. "Mistérios nos números: peculiaridade no número três". José Laércio do Egito - FRC. Disponível em: http://www.joselaerciodoegito.com.br/site tema389.htm. Acesso em: 30 jan. 2007.

174 Raymond Abellio, pseudônimo do escritor francês Georges Soulès, nascido em 11 de novembro de 1907, em Toulouse, e morto em 26 de agosto de 1986, em Nice. 
Casemiro havia amarrado a espingarda com um cipó para que, em vez de carregá-la, pudesse arrastá-la. Assim caminhava ele, seguindo o piar da coruja, até que um "insuportável coro de sapos" 175 o fez perder o contato sonoro com a ave. Também não percebeu que a borboleta prata se afastara dele. De repente, fez-se ouvir no meio da mata um forte relâmpago, seguido imediatamente de chuva pesada. Pequeno do jeito que estava, o menino foi arrastado pelas águas.

O sapo traz consigo todos os significados nascidos da grande cadeia simbólica água-noite-Lua-yin. ${ }^{176}$ Vê-se mais uma vez a presença dos elementos femininos, de polaridade negativa, relativos à anima, que continuam a impulsionar e orientar a incursão de Casemiro pela floresta, isto é, pelo inconsciente. Em várias culturas, o sapo desempenha o papel de anunciador de chuva; está ligado à água, à terra, à mulher e à umidade. "Como todos os símbolos associados ao complexo terra-água-Lua, ele exprime esotericamente o conceito de morte e de renovação." 177 Mais uma vez o conceito de transformação está associado à trajetória de Casemiro.

Ao ser arrastado pela enxurrada, o garoto perde a espingarda. Chevalier e Gheerbrant ${ }^{178}$ anotam o significado da arma:

A arma é o antimonstro que, por sua vez, se torna monstro. Forjada para lutar contra o inimigo, pode ser desviada de sua finalidade e servir para dominar o amigo, ou simplesmente, o outro. [...] A ambigüidade da arma está no fato de simbolizar a um só tempo o instrumento da justiça e da opressão, a defesa e a conquista. Em qualquer hipótese a arma materializa a vontade dirigida para um objetivo.

Despojado da arma, Casemiro está ao mesmo tempo indefeso e sem condições de ataque, acima da justiça e da opressão, para além do bem e do mal. Encontra-se, dessa forma, destituído de qualquer vontade dirigida para um objetivo. Subentende-se da narrativa ser essa a postura que deve observar todo indivíduo que deseje entrar em contato com os conteúdos do inconsciente, pessoal ou coletivo. Em sentido amplo, essa é a disposição que se deve manter caso se queira

\footnotetext{
${ }^{175}$ O relógio do mundo, p. 18.

${ }^{176}$ CHEVALIER, Jean e GHEERBRANT, Alain. Dicionário de símbolos: mitos, sonhos, costumes, gestos, formas, figures, cores, números. Trad. Vera da Costa e Silva, Raul de Sá Barbosa, Ângela Melim, Lúcia Melim. Rio de Janeiro, José Olympio, 1988, p. 803.

177 Idem, ibidem.

${ }^{178}$ Idem, ibidem, p.80.
} 
penetrar nos mistérios mais profundos da existência. Pode-se, neste ponto, traçar um paralelo dos símbolos mobilizados pelo narrador com as práticas da psicoterapia e da meditação transcendental. No campo da psicologia analítica, o paciente precisa estar totalmente livre de interpretações prévias, estandardizadas, de modo a abrir-se para o processo cognitivo propiciado pela investigação das mensagens simbólicas que emergem das imagens oníricas. Referentemente à meditação, também o asceta precisa desapegar-se de objetivos estabelecidos e esvaziar a mente de expectativas com relação ao resultado da prática. Mais ainda, deve interromper todo tipo de pensamento. Do que se expôs, infere-se que o contato com as camadas mais profundas do inconsciente, única forma de acesso à integralização da personalidade, ao self, só pode se dar com a mente e o espírito "desarmados".

Casemiro foi escorregando pela mata, até cair dentro de um rio. A riqueza imagética expressa em tão curto trecho narrativo é tal, que esse merece ser reproduzido.

[Casemiro] Sentiu o choque de ser lançado dentro da outra correnteza. Se viu afundando, se misturando à lama que levantava do fundo. Se viu tragado para dentro de um buraco. Se viu caindo, caindo, caindo... Caiu muito fundo, e não havia mais água em volta dele. Era como se descesse por um poço de paredes úmidas, que, secando, iam virando pedra. Finalmente, desabou sobre um chão de areia.

Mas não se sentiu machucado. Apenas dolorido e molhado. Olhou em volta: as paredes brilhavam. Eram grandes blocos de ouro. ${ }^{179}$

Apenas a título de curiosidade, sem a intenção de se fazer uma análise comparativa, alude-se à intertextualidade do fragmento acima com o episódio clássico de Aventuras de Alice no país das maravilhas. ${ }^{180}$ A menina, ao ver um coelho tirar um relógio do bolso do colete, olhar as horas, e depois sair em disparada, levantou-se num pulo.

No instante seguinte, lá estava Alice se enfiando na toca atrás dele, sem nem pensar de que jeito conseguiria sair depois.

${ }^{179}$ O relógio do mundo, p. 19.

${ }^{180}$ CARROL, Lewis. Alice: edição comentada. Trad. Maria Luiza X. de A. Borges. Rio de Janeiro, Jorge Zahar Ed., 2002, pp. 11-4. 
Por um trecho, a toca de coelho seguia na horizontal, como um túnel, depois se afundava de repente tão de repente que Alice não teve um segundo para pensar em parar antes de se ver despencando num poço muito fundo. [...]

Caindo, caindo, caindo. [...] A queda não terminaria nunca? "Quantos quilômetros será que já caí até agora?", disse [Alice] em voz alta. "Devo estar chegando perto do centro da Terra."

[...] subitamente, bum! bum! [a menina] caiu sobre um monte de gravetos e folhas secas: a queda terminara.

Alice não ficou nem um pouco machucada, e num piscar de olhos estava de pé.

Voltando ao texto em estudo, Casemiro também chegará perto do centro da Terra. Essa passagem do enredo, do momento em que o garoto é carregado pela enxurrada até cair na gruta cujas paredes eram de ouro, pode ser mais bem compreendida ao se observar a inter-relação simbólica que se estabelece entre rio, poço e caverna.

O simbolismo do rio e o do fluir de suas águas é, ao mesmo tempo, o da possibilidade universal e o da fluidez das formas, o da fertilidade, da morte e da renovação. O rio simboliza sempre a existência humana e o curso da vida, com a sucessão de desejos, sentimentos e intenções, e a variedade de seus desvios. A travessia de uma margem a outra é a superação de um obstáculo que separa dois domínios, dois estados: o mundo fenomenal e o estado incondicionado; o mundo dos sentidos e o estado de não-vinculação. A margem oposta é o estado que existe para além do ser e do não-ser. "Entre os gregos, os rios eram objeto de culto; eram quase divinizados, como filhos do Oceano e pais das Ninfas. [...] Não se podia atravessá-los senão após ter cumprido os ritos da purificação e da prece." 181

Casemiro atingirá o outro lado do rio, mas antes deverá passar por um processo de aprendizagem. Será preparado para alcançar o estado do não-ser, estado esse que vinha se delineando desde quando começara a encolher fisicamente. Como foi visto, ele havia sido desarmado, isto é, despojado de qualquer vontade dirigida. Essa disposição é ilustrada, primeiro, pelo fato de não ter certeza se devia ou não matar a coruja; segundo, porque havia se perdido da ave, símbolo

${ }^{181}$ CHEVALIER, Jean e GHEERBRANT, Alain. Dicionário de símbolos: mitos, sonhos, costumes, gestos, formas, figures, cores, números. Trad. Vera da Costa e Silva, Raul de Sá Barbosa, Ângela Melim, Lúcia Melim. Rio de Janeiro, José Olympio, 1988, p. 781. 
do pensamento racional; terceiro, porque imaginara na queda que sua história acabaria ali.

O ritual de purificação ao qual Casemiro será submetido ocorrerá no interior da caverna, aonde ele chega depois de cair em um profundo poço. O poço se reveste de um caráter sagrado em todas as tradições. Ele realiza uma espécie de síntese de três ordens cósmicas: céu, terra, infernos; de três elementos: a água, a terra e o ar; ele é uma via vital de comunicação. Em numerosos contos esotéricos, retoma-se a imagem do poço do conhecimento ou da verdade (a verdade está no fundo do poço). ${ }^{182}$

No fim do poço, Casemiro estará no interior da caverna. Segundo Jung ${ }^{183}$, a gruta, além de ser uma das formas simbólicas do arquétipo materno, "é lugar do renascimento, aquele espaço oco secreto em que se é encerrado, a fim de ser incubado e renovado". No campo do mito, assim como no da psicologia analítica, a caverna é arquétipo do útero materno, e figura nos ritos de origem, de renascimento e de iniciação de numerosos povos, conforme esclarece Brandão ${ }^{184}$ :

As grutas e cavernas desempenham um papel religioso muito importante, não apenas na religião cretense, mas em todas as culturas primitivas. A descida a uma caverna, gruta ou labirinto simboliza a morte ritual, do tipo iniciático. Nesse e em outros ritos da mesma espécie, passava-se por "uma série de experiências" que levavam o indivíduo aos começos do mundo e às origens do ser, donde o "saber iniciático é o saber das origens". Esta catábase é a materialização do regressus ad uterum, isto é, do retorno ao útero materno, donde se emerge de tal maneira transformado, que se troca até mesmo de nome. O iniciado se torna outro.

A idéia de que todo rito de iniciação representa um retorno às origens, isto é, ao útero materno também está presente nas pesquisas de Eliade ${ }^{185}$.

[...] temos o conhecido simbolismo dos rituais iniciatórios implicando um regressus ad uterum. [...] Desde os estádios arcaicos da

\footnotetext{
182 Idem, ibidem, pp. 726-7.

183 JUNG, Carl Gustav. Os arquétipos e o inconsciente coletivo. Trad. Maria Luíza Appy e Dora Mariana R. Ferreira da Silva. Petrópolis, Vozes, 2000, p. 139.

184 BRANDÃO, Junito de Souza. Mitologia grega. Vol.I, Petrópolis, Vozes, 1986, p. 54.

185 ELIADE, Mircea. Mito e realidade. Trad. Pola Civelli. 6.ed., São Paulo, Perspectiva, 2002, p. 75.
} 
cultura, a iniciação dos adolescentes comporta uma série de ritos cujo simbolismo é patente: trata-se de transformar o noviço em embrião, a fim de fazê-lo renascer depois. A iniciação equivale a um segundo nascimento. É por meio da iniciação que o adolescente se torna uma criatura socialmente responsável e, ao mesmo tempo, culturalmente desperta. O retorno ao útero é expresso quer pela reclusão do neófito numa choça, quer pelo fato de ser simbolicamente tragado por um monstro, quer pela penetração num terreno sagrado identificado ao útero da MãeTerra.

O conjunto simbólico não deixa a menor dúvida de que Casemiro só pode atravessar o rio rumo a Cucura, isto é, passar do mundo fenomenal para o estado incondicionado; só pode atingir o estado para além do ser e do não-ser depois de ter voltado às origens, de ter nascido novamente por meio da experiência da iniciação, que se dará, como em um dos exemplos levantados por Eliade, "num terreno sagrado identificado ao útero da Mãe-Terra". Acompanha-se adiante como se dá o rito iniciático do protagonista.

No interior da caverna, o garoto encontra quatro pequenas criaturas. Seres diminutos habitando o interior da Terra remetem aos gnomos. Chevalier e Gheerbrant ${ }^{186}$ descrevem-nos como gênios de pequeno tamanho, que, segundo a Cabala, habitariam debaixo da terra e seriam donos dos tesouros de pedras e metais preciosos. A lenda dos gnomos passou do Oriente para a Escandinávia e para a América Central. Simbolizariam o ser invisível, que, por inspiração, intuição, imaginação e sonho, fazem visíveis os objetos invisíveis. $\mathrm{Na}$ alma dos homens eles são como que lampejos de consciência, de iluminação e de revelação. São como que a alma oculta das coisas, orgânicas ou não; e quando eles se retiram, as coisas morrem ou ficam inertes e tenebrosas.

Em O relógio do mundo, Lino de Albergaria transporta a lenda dos gnomos para o Brasil e a reveste com elementos da cultura nacional. Empresta aos elementais da terra, guardiões das pedras e metais preciosos, a aparência dos ameríndios brasileiros.

${ }^{186}$ CHEVALIER, Jean e GHEERBRANT, Alain. Dicionário de símbolos: mitos, sonhos, costumes, gestos, formas, figures, cores, números. Trad. Vera da Costa e Silva, Raul de Sá Barbosa, Ângela Melim, Lúcia Melim. Rio de Janeiro, José Olympio, 1988, pp. 472-3. 
Eram quatro as tais pequenas criaturas. Do mesmo tamanho, sim, do Amarelinho, mas bem diferentes. Eram morenos, a cor bronzeada dos índios. Os cabelos corridos e escuros, assim como os olhos. E não se vestiam de nada, além da própria pele. ${ }^{187}$

Além da descrição, sugerem a etnia dos índios brasileiros também os nomes desses seres telúricos: Caboré, Cafofo, Cacorê e Capi.

Caboré, variação de caburé, vem do tupi kauu're e tem diferentes acepções. Entre essas, dois tipos de aves, uma falconiforme, típica do Amazonas; outra da família dos bubonídeos, espécie de mocho. No entanto, interessa mais ao contexto os sentidos de: "mestiço de negro e índia, cafuzo" 188; "tipo de caboclo um tanto mais claro; indígenas cariris, aliados aos janduís, no Rio Grande do Norte". ${ }^{189}$ Cafofo, de origem obscura, é sinônimo de cafua, caverna, sepultura, cova, antro. Em Minas Gerais, designa "terreno pantanoso onde a decomposição de matérias orgânicas ocasiona exalações características das águas apodrecidas em charco." ${ }^{190}$ Embora não localizados em referências lexicográficas, Cacorê e Capi fazem referência por derivação a nomes indígenas.

A idéia de gnomos revestidos de índios brasileiros é fortalecida ainda pela função que Capi, Cacorê, Caboré e Cafofo exercem. Além de guardarem o precioso metal, representam para a "alma" de Casemiro lampejos de consciência. $O$ fato de serem quatro refere-se às formas por meio das quais, segundo a psicologia junguiana, a consciência se orienta com relação ao mundo dos fenômenos, e que correspondem aos pares de funções/tipos psicológicos: pensamento-sentimento, sensação-intuição.

O quatérnio é um arquétipo, por assim dizer, universal. Constitui o pressuposto lógico de todo julgamento da totalidade. Tal julgamento pressupõe um aspecto quádruplo. Por exemplo: para descrever a totalidade do horizonte, designamos os quatro pontos cardeais. Há sempre quatro elementos, quatro qualidades primeiras, quatro cores, quatro castas na Índia, quatro vias de desenvolvimento espiritual no budismo. Por este

${ }^{187}$ O relógio do mundo, p. 20.

${ }^{188}$ CUNHA, Antonio Geraldo da. Dicionário etimológico Nova Fronteira da língua portuguesa. 2.ed., Rio de Janeiro, 1986, p. 132.

${ }^{189}$ CASCUDO, Luís da Câmara. Dicionário do folclore brasileiro. 11. ed., rev., atual. e ilust., São Paulo, Global, 2002, p. 90.

${ }^{190}$ FERREIRA, Aurélio Buarque de Holanda. Novo Aurélio século XXI: o dicionário da língua portuguesa. 3.ed., rev. e ampl., Rio de Janeiro, Nova Fronteira, 1999, p. 362. 
motivo também existem quatro aspectos psicológicos na orientação psíquica. ${ }^{191}$

Sugere-se assim a necessidade de Casemiro integralizar em sua personalidade as quatro funções. A julgar pelo modo diferente como os pequenos índios se comportam, pode-se associar cada um deles a um tipo psicológico junguiano. Cacorê, sempre sério e zangado, corresponde mais à intuição, pois "lê" o que se passa na mente de Casemiro. Cafofo e Caboré, atentos ao bem-estar do garoto, correlacionam-se respectivamente ao sentimento e à sensação. Capi, por sua vez, é todo pensamento. É ele quem revela para o menino o mistério da gruta.

E Capi disse:

- Este ouro é o segredo da terra, guardado em cima pela água e cá embaixo por nós quatro. Hoje é ouro, ontem foi ferro. Aqui os metais são vivos. Eles crescem e se transformam. O ferro amadurece em ouro. Mas o ouro tem de continuar aqui, para este mundo girar em volta do Sol, com noites e dias, calor e frio... Enquanto o ouro viver aqui, a água continua brotando nas fontes e as sementes rebentando na terra. As árvores crescerão e os bichos e os homens continuarão nascendo. Este é o metal que mantém a vida, o relógio do mundo. Por tudo isso, fique sabendo, este ouro nunca pode deixar este lugar. ${ }^{192}$

O caminho duplo pelo qual segue a interpretação do texto ganha forte realce no trecho acima, em que o narrador explicita o título da obra. Tem-se, quanto ao significado amplo do enredo, a expressão metafórica do discurso ambientalista, presente na mídia com certa freqüência desde o último quarto do século $X X$. Referentemente ao percurso do protagonista, conota-se a ascese espiritual pelo caminho da alquimia. Comenta-se inicialmente a questão ambiental. O tema da preservação da natureza, por subjazer ideologicamente à trama narrativa, julga-se merecer alguma contextualização histórica.

Em 1989, no texto de O relógio do mundo, Lino de Albergaria já abordava as preocupações de alguns setores sociais atentos à necessidade de renovação das matrizes energéticas que sustentam os modelos de desenvolvimento econômico.

191 JUNG. Carl Gustav. Memórias, sonhos e reflexões: reunidas e editadas por Aniela Jaffé. Trad. Dora Ferreira da Silva. Rio de Janeiro, Nova Fronteira, 1975, p. 357.

192 O relógio do mundo, p. 23. 
Uma das polêmicas pioneiras sobre assunto a ganhar repercussão mundial parece ter sido aquela referente à camada de ozônio da estratosfera. A primeira declaração científica sobre os perigos da destruição de ozônio surgiu em 1974, motivada pela descoberta da presença de clorofluorcarbonos (CFCs) na atmosfera, por James Lovelock. Naquele ano, Sherwood Rowland e Mario Molina, que mais tarde receberiam o Prêmio Nobel de Química, abriram caminho para o atual entendimento dos processos pelos quais os CFCs se difundem até a estratosfera, são degradados e destroem as moléculas de ozônio. A partir daí, os efeitos nocivos desse problema para a saúde e o bem-estar dos povos e ecossistemas, com possíveis riscos então desconhecidos para o clima do Planeta, viraram pauta de discussões em diferentes foros.

Gerado por indústrias químicas na produção de diversos bens de consumo, o buraco na camada de ozônio chamou a atenção do Programa das Nações Unidas para o Meio Ambiente (o UNEP, da sigla em inglês para United Nations Environment Program), a ponto de, em março de 1977, suscitar o encontro nos Estados Unidos, em Washington D.C., de especialistas de 32 países para criarem o Plano Mundial de Ação sobre a Camada de Ozônio. De lá em diante, a ONU, mesmo ainda sem provas contundentes sobre a extensão do mal, em associação com a comunidade científica internacional, passou a organizar iniciativas voltadas para o encontro de soluções. Um dos primeiros marcos dessa busca foi a conclusão na Áustria, em 22 de março de 1985, da Convenção de Viena para a Proteção da Camada de Ozônio, ratificada por 28 países.

Entre as resoluções adotadas na ocasião destacava-se a cessão de poderes ao UNEP para organizar a realização de um protocolo da convenção. As negociações em torno do evento foram aceleradas em virtude da publicação, apenas dois meses após o encontro de Viena, das descobertas dos membros da British Antartic Survey, liderados pelo Dr. Joe Farman. Em famoso artigo sobre o "buraco de ozônio" revelava-se a existência de declínios dramáticos nas concentrações de ozônio sobre a Antártica. Como conseqüência, em 16 de setembro de 1987, 46 países assinaram, no Canadá, o Protocolo de Montreal sobre Substâncias que Destroem a Camada de Ozônio. Em 1995, a Assembléia Geral das Nações Unidas 
declarou o dia 16 de setembro como o Dia Internacional para a Preservação da Camada de Ozônio. ${ }^{193}$

Paralelamente às questões do ozônio, o mundo passou a enfrentar, a partir da década de 1980, problemas relacionados com as perceptíveis mudanças climáticas. Como resultado da primeira reunião global entre governantes e cientistas para tratar do assunto, realizada no ano de 1988 em Toronto, no Canadá, descreveu-se o impacto potencial da crescente emissão na atmosfera de dióxido de carbono $\left(\mathrm{CO}_{2}\right)$ - o principal gás-estufa - como inferior apenas ao que pode causar uma guerra nuclear. A partir daquela data, sucessivos anos com altas temperaturas têm batido os recordes mundiais de calor, fazendo da década de 1990 a mais quente desde que existem registros. No mesmo ano do encontro no Canadá, foi criado pela ONU o Painel Intergovernamental sobre Mudança Climática (o IPCC, da sigla em inglês para Intergovernmental Panel on Climate Change), cujo objetivo é compilar a informação científica no mundo sobre mudança global do clima e produzir relatórios que informem o estado da arte do conhecimento sobre o assunto.

O primeiro informe produzido pelo IPCC foi divulgado em 1990, alertando para a necessidade de se reduzir em $60 \%$ as emissões de $\mathrm{CO}_{2}$, com base nos índices daquele ano. Em 1992, mais de 160 governos assinaram a Convenção Marco sobre Mudança Climática, durante a realização da Cúpula da Terra, no Rio de Janeiro (a ECO-92), como medida para "evitar interferências antropogênicas perigosas no sistema climático". Três anos depois, em 1995, publicava-se o segundo informe dos cientistas do IPCC, por meio do qual se declarava a conclusão de que os primeiros sinais de mudança climática por ação humana eram evidentes. Estava lançado um grande desafio aos poderosos grupos industriais nos setores de extração e comercialização de combustíveis fósseis. Em novo encontro, no ano de 1997, realizado dessa vez no Japão, é assinado o Protocolo de Kyoto, em evento que ficou conhecido como a Conferência das Partes. O tratado continha um acordo que comprometia especialmente os países do hemisfério Norte a reduzirem sistematicamente suas emissões de $\mathrm{CO}_{2}$. Porém, sabe-se que desde lá, passandose ainda pela Conferência do Clima, ocorrida em 2005, em Montreal, Canadá, muito

193 "ACTION on ozone". UNEP Secretaria do Ozônio. Programa das Nações Unidas para o Meio Ambiente. Nairobi, nov. 1996. Disponível em: http://www.ambiente.sp.gov.br/prozonesp/Actiozon/0z0100.htm. Acesso: em 13 mar. 2007. 
pouco se avançou em termos de ações ${ }^{194}$, até 2007 . O editorial da revista Princípios ${ }^{195}$, edição nº. 83, comenta o assunto:

[...] os termos dos acordos firmados em defesa da preservação ambiental e do desenvolvimento sustentado são "bombardeados" pelas grandes potências - em particular os Estados Unidos. Os países em desenvolvimento, sobretudo os que têm à sua frente governos progressistas, lutam numa correlação de forças desigual contra o irracional modelo que está levando à mutilação o nosso planeta.

Os EUA, por exemplo, um dos países mais dependentes de combustíveis fósseis e um dos que mais emitem dióxido de carbono na atmosfera $\left(36,1 \%{ }^{196}\right.$, desistiram do tratado de Kyoto em 2001, sob a desculpa de que o pacto era caro demais e excluía de maneira injusta os países em desenvolvimento. O presidente americano George W. Bush alegou, à época, ausência de provas de que o aquecimento global estivesse relacionado à poluição industrial. Também em 2001 vem a público o terceiro relatório do IPCC no qual se previa um aumento global da temperatura de 1,4 a 5,9 graus, em 100 anos, com a conseqüente elevação do nível médio dos mares causada pelo degelo das calotas polares e glaciais. Essas previsões foram corrigidas em fevereiro de 2007 pela primeira parte do quarto relatório do PCC, publicado na França havia pouco mais de um mês do momento em que se redigia esta análise. Sobre as informações contidas no documento, relata Leite, enviado especial a Paris pela Folha de S. Paulo ${ }^{197 .}$

A temperatura da atmosfera subirá pelo menos mais $1,8^{\circ} \mathrm{C}$ além do $0,76^{\circ}$ já escalado desde tempos pré-industriais. O mais provável é que totalize $3^{\circ} \mathrm{C}$ até o fim deste século, mas não está de todo descartado que galope para mais de $4^{\circ} \mathrm{C}$.

194 "O PROTOCOLO de Kyoto". Greenpeace. São Paulo, s/d. Disponível em: http://www.greenpeace.org.br/clima/pdf/protocolo kyoto.pdf. Acesso em: 13 mar. 2007.

195 "DESAFIO do século XXI: desenvolvimento com preservação ambiental". Vermelho. "Revista Princípios". São Paulo, $\mathrm{n}^{\circ}$. 83. s/d. Disponível em:

http://www.vermelho.org.br/museu/principios/anteriores.asp?edicao=83. Acesso em: 13 mar. 2007.

196 "ENTENDA o Protocolo de Kyoto". Época on line. Rio de Janeiro, mai. 2006. Disponível em: http://revistaepoca.globo.com/Epoca/0,6993,EPT908417-1655-1,00.html. Acesso em: 13 mar. 2007.

197 LEITE, Marcelo. "A culpa é nossa". Folha de S. Paulo, São Paulo, 3 fev. 2007. "Caderno Especial Clima", p. 1. 
A imensa geleira sobre a Groelândia pode desaparecer em alguns milênios, como há 125 mil anos, elevando os mares em $7 \mathrm{~m}$. No século 20 , o nível do mar subiu 17 cm, mais aceleradamente após 1993.

O IPCC prevê que subirá $18 \mathrm{~cm}$ a $59 \mathrm{~cm}$ daqui para frente até 2100. Seria devastador para a população de milhares de cidades costeiras $[\ldots]$.

Onze dos últimos 12 anos foram os mais quentes jamais registrados desde 1850. Nada de semelhante aconteceu nos últimos $20 \mathrm{mil}$ anos, ou talvez 650 mil anos, como revela a composição de bolhas de ar aprisionadas no gelo da Antártida.

Apesar de datados e sujeitos a toda sorte de modificações, de acordo com os avanços das pesquisas, os dados acima revelam o estágio de conhecimento científico a respeito das interferências antrópicas no clima da Terra no ano de 2007. Justifica-se a reprodução dessas informações no presente trabalho uma vez que elas ratificam no mundo real aquilo que Lino de Albergaria antecipava simbolicamente no plano da ficção literária para jovens há quase 20 anos. A gana de ouro do povo de Cravo Branco equivale à dependência que a humanidade contemporânea tem de consumir recursos naturais, extraídos quase sempre de forma insustentável. Sob esse aspecto, a mensagem contida na obra é inequívoca: ao desregular o relógio do mundo, o homem faz avançar os ponteiros do relógio do fim do mundo. Também neste ponto, os fatos reais confirmam a essência semânticoargumentativa do texto em estudo. Em 17 de janeiro de 2007, simultaneamente em Washington e Londres, o Boletim de Cientistas Atômicos (BAS) adiantou em dois minutos o Relógio do Apocalipse, que passou a marcar cinco para a meia-noite. $O$ BAS, fundado por um grupo de participantes do Projeto Manhattan, que fabricou a primeira bomba atômica, criou o relógio em 1947 para simbolizar os riscos das armas nucleares para humanidade. Dessa vez, o grupo de cientistas alertou também sobre o fracasso do mundo em resolver os problemas representados pela crise do aquecimento global.

Em meio a um cenário de escatologia caminha o protagonista de O relógio do mundo. É a natureza em desequilibro, violentamente descontrolada, que atira Casemiro para o fundo do poço, numa tentativa de fazê-lo enxergar a luz da alquimia. A origem histórico-mítica mais classicamente atribuída à alquimia é a da ciência de Hermes Trimegisto - o três vezes grande. Hermes é descrito ou 
identificado ora como um rei egípcio ora como um mestre espiritual analógico a Moisés. Porém, a alquimia tem sua gênese também remontada à figura do deus egípcio Thot, o que leva alguns mitólogos a imaginar uma equivalência entres Hermes e Thot, a ponto de juntá-los num único nome Hermes-Thot. Simbolicamente, Hermes denota aquele que desvenda e, com esse sentido, tem como correspondente feminino a deusa egípcia Isis, cuja representação é encontrada numerosas vezes nas imagens alquímicas. Daí o fato de Isis também ser apontada como fundadora da alquimia. ${ }^{198}$

A alquimia é a arte da transmutação dos metais com vistas à obtenção de ouro. Implica uma intervenção do homem no ritmo temporal próprio das substâncias minerais vivas. Denominada em textos sagrados como a Grande Obra ou a Arte Real, a alquimia é considerada extensão e aceleração da geração natural. Quimicamente falando, é a ação do enxofre (princípio denso) sobre o mercúrio (princípio volátil), mediatizado pelo sal (princípio de fixação), que dá origem aos minérios na matriz terrestre, na qual a transmutação se efetua. A terra é o cadinho em que, lentamente, os minérios amadurecem; onde o bronze e o ferro convertemse em ouro. Porém, essa operação jamais é empreendida com o objetivo de usufruto material, uma vez que a alquimia não é, de fato, uma pré-química, mas uma operação simbólica. O ouro simboliza a imortalidade e o processo alquímico, a transmutação da individualidade humana.

Em suas pesquisas no campo da psicologia analítica, Jung ${ }^{199}$ reconheceu a semelhança entre o material produzido pelos seus pacientes e a alquimia no tocante aos significados que buscava para os sonhos. Para ele, o equivalente psicológico da alquimia é a projeção de um conteúdo inconsciente de caráter numinoso, "divino" ou "sagrado".

A alquimia propõe-se a alcançar este "tesouro difícil de ser alcançado" [a projeção de um conteúdo inconsciente de caráter numinoso] e a produzi-lo de forma visível na medida em que a Arte se exerce no laboratório, quer sob a forma do ouro físico, quer como panacéia, quer sob a forma de tintura com poder de transformação. No entanto, uma vez que a atividade química prática jamais foi inteiramente pura, exprimindo também

198 "A METÁFORA alquímica". IJRS, Porto Alegre, s/d. Disponível em: http://www.ijrs.org.br/artigos.php?id=8. Acesso em: 5 fev. 2007.

199 JUNG, Carl Gustav. Psicologia e alquimia. Trad. Dora Mariana Ribeiro Ferreira da Silva. 2.ed., Petrópolis, Vozes, 1994, p. 360. 
em si e por si os conteúdos do inconsciente do operador, ela era simultaneamente uma atividade psíquica à qual se poderia comparar à imaginação ativa. Aquilo que se capta ativamente através deste método também se exprime na vida onírica. As relações do mundo da intuição e dessas duas formas do processo de interpenetração inconsciente-consciente são tão próximas a ponto de ser justo supor-se que no procedimento alquímico se trata de processos semelhantes ou iguais aos da imaginação ativa e dos sonhos, e enfim ao processo de individuação.

Para os alquimistas, a Grande Obra é compreendida como uma alegoria dialética com a própria evolução do homem, que consistiria no equilíbrio perfeito entre matéria (representada pelo enxofre) e espírito (simbolizado pelo mercúrio) mediatizado pelo espírito do universo (o sal). A busca pela transmutação dos metais em ouro volta-se para a meta maior que é a do estabelecimento da perfeita harmonia do homem consigo mesmo, na sua dupla dimensão de corpo e alma, e também com todo o cosmo. Considerando os minerais do mesmo modo como os animais e os vegetais, os alquimistas acreditam na existência de uma semente dos metais, daí as denominações de ovo filosófico, ovo do mundo ou embrião de ouro, em analogia ao feto do reino animal, dadas ao vaso onde se opera a obra metálica. Essa obra consiste na fundição dos ingredientes no cadinho, que, em termos simbólicos representa o retorno à matriz, ao estado embrionário. Como se percebe, na trajetória de Casemiro, por meio da representação alquímica, reitera-se no texto estudado o símbolo de retorno ao útero, já denotado antes por meio da cena em que o menino cai no interior da caverna.

Na dialética da geração natural do ouro no interior da terra com a alquimia, o forno, onde se dá o processo alquímico empreendido pelo homem, está simbolicamente em paralelo com a caverna. Esta, por sua vez, além de representar o ventre materno, está simbolicamente para um espaço que o homem, na prática da alquimia, descobre em si mesmo: a caverna do coração. O fogo que aquece o forno é associado ao conhecimento intuitivo, que aciona o processo. É o que se infere a partir da explicação de Chevalier e Gheerbrant ${ }^{200 .}$

${ }^{200}$ CHEVALIER, Jean e GHEERBRANT, Alain. Dicionário de símbolos: mitos, sonhos, costumes, gestos, formas, figures, cores, números. Trad. Vera da Costa e Silva, Raul de Sá Barbosa, Ângela Melim, Lúcia Melim. Rio de Janeiro, José Olympio, 1988, p. 38-9. 
A alquimia [...] é menos uma ciência do que um conhecimento. É aplicada com maior freqüência aos metais, segundo uma física simbólica das mais desconcertantes aos olhos do cientista. A alquimia material e a alquimia espiritual supõem um conhecimento dos princípios de ordem tradicional, baseando-se muito mais numa teoria das proporções e das relações, do que numa análise verdadeiramente físico-química, biológica ou filosófica dos elementos que são postos em relação uns com os outros. Linguagem e lógica são, para ela, de natureza simbólica.

A afirmação dos dicionaristas vai ao encontro do que se diz em artigo sobre o assunto publicado pelo IJRS — Instituto Junguiano do Rio Grande do Sul ${ }^{201}$ : a "ciência alquímica não se adquire pelo intelecto e pelos livros, mas por um impulso, uma impetuosidade do espírito". E o que seriam esse impulso e essa impetuosidade do espírito senão a intuição? É a intuição que leva o indivíduo a entrar em contato com os conteúdos do inconsciente e desencadeia o processo de individuação. É a intuição que tanto falta ao povo de Cravo Branco.

Ao cair na caverna, Casemiro depara-se com o processo alquímico natural, vigiado por "gnomos indígenas", que, por meio do fogo, isto é, por meio do conhecimento intuitivo, Ihe mostram uma coruja, nos olhos da qual o menino verá Cucura, etapa obrigatória no caminho de sua evolução psicológica. Reproduzem-se os principais fragmentos da cena:

— Olhe para o fogo — disse Capi.

$[\ldots]$

E Casemiro viu dentro da chama não uma cidade, mas uma coruja que olhava para ele, bem dentro dos olhos.

[...]

— Mas não vejo cidade nenhuma...

- Olhe bem dentro dos olhos da coruja - Capi dizia.

A coruja olhava Casemiro. Casemiro olhou nos olhos dela. Eles refletiam uma cidade dividida em duas, cada metade dentro de um olho. Cheia de torres, toda de pedra, construída em degraus, numa elevação. Havia muitos muros, um por trás do outro, e ruas estreitas entre eles, subindo a colina... Aquilo não parecia um labirinto? ${ }^{202}$

\footnotetext{
201 "A METÁFORA alquímica". IJRS, Porto Alegre, s/d. Disponível em: http://www.ijrs.org.br/artigos.php?id=8. Acesso em: 5 fev. 2007.

202 O relógio do mundo, pp. 23-4.
} 
Retomando alguns dos símbolos já descritos, depreende-se mais uma vez que é por meio do conhecimento intuitivo (fogo) que a consciência (coruja) se ilumina. Essa, por sua vez, transmite ao seu próprio centro, o ego, o conhecimento racional. A mensagem implícita da narrativa é a de que Casemiro deve, no sentido simbólico, ser o alquimista de sua própria evolução material (corporal-mental) e espiritual (psíquica). Informações veiculadas em artigo no IJRS ${ }^{203}$ corroboram para confirmar as associações de idéias:

O alquimista tinha que aprender a entender aquilo que eles chamavam a linguagem dos pássaros ou linguagem das aves, das verdades olvidadas, das evidências para almas de crianças, expressando a idéia que a linguagem das aves era a que os adeptos utilizavam a fim de se reconhecerem na consumação da obra e de se protegerem da curiosidade do profano.

Como tudo ocorre dentro da caverna, vale pormenorizar as possibilidades interpretativas sugeridas por esse símbolo. Na tradição grega, a caverna encerra estreitamente ligados um simbolismo metafísico e um simbolismo moral. Essa união está presente no famoso mito de Platão. Segundo o filósofo, alguns homens vivem em uma morada subterrânea que tem uma entrada a abrir-se amplamente para o lado da luz. Esses homens estão, desde à infância, acorrentados pelas pernas e pelo pescoço de modo a permanecerem sempre no mesmo lugar, voltados para o fundo do recinto, sem poderem, por causa das correntes, girar a cabeça circularmente. A única luz que lhes chega é a que provém de um fogo que arde por trás deles ao longe. Desse modo, a referência que eles têm do mundo externo consiste apenas nas sombras que o jogo de luzes, proporcionado pelo fogo e pelo lado de fora, projeta no interior da caverna. Para Platão, essa é a situação dos homens na terra. A luz indireta que chega às paredes subterrâneas provém de um sol invisível, mas indica o caminho que a alma deve seguir a fim de encontrar o bem e a verdade. A projeção das sombras representa esse mundo de aparências

203 "A METÁFORA alquímica". IJRS, Porto Alegre, s/d. Disponível em: http://www.jirs.org.br/artigos.php?id=8. Acesso em: 5 fev. 2007 
agitadas, do qual a alma deve sair para contemplar o verdadeiro mundo das realidades - o mundo das Idéias. ${ }^{204}$

Entre tantas outras possibilidades, a caverna simboliza a exploração do eu interior e, mais particularmente, do eu primitivo, recalcado nas profundezas do inconsciente, onde muitas vezes estão soterrados perigos inesperados. No âmago de si próprio, Casemiro revela trazer as sombras do mundo das aparências. Afinal, nascera em Cravo Branco e está imbuído dos valores de seu povo. Tanto é que também cobiça o ouro. Ao ver as paredes da gruta brilhando, pensa no pai e nos irmãos. Imagina a possibilidade de levar um pouco do rico minério para casa. $E$ ainda não será nesse retorno à matriz que adquirirá total consciência dos próprios processos, uma vez que o regressus ad uterum é apenas uma etapa do caminho, mas de importância fundamental.

A caverna também é considerada um gigantesco receptáculo de energia telúrica e, por essa razão, desempenha importante papel nas operações mágicas. Quer seja habitação de trogloditas ou símbolo, a gruta tem sempre uma abertura central na abóbada, destinada à passagem da fumaça da lareira, da luz, da alma dos mortos ou de xamãs, que pode ser compreendida como a porta do sol por onde se efetua a saída para o cosmo. Chevalier e Gheerbrant ${ }^{205}$ notam que o cadinho dos alquimistas e o crânio humano têm a mesma abertura no topo, tanto um como outro podendo ser assimilados à caverna. Há ainda várias interpretações secundárias com relação ao caráter da caverna. Entre essas, cumpre destacar aquela segundo a qual ela abriga os minérios e os anões guardiões dos tesouros ocultos, representados, em O relógio do mundo, pelos quatro pequenos índios.

Resumindo, Lino de Albergaria amalgama, nessa passagem em que Casemiro cai na caverna, elementos simbólicos da alquimia e dos ritos de passagem das sociedades arcaicas à teoria psicológica segundo a qual se explica a volta simbólica ao ventre materno como um renascer transformado. Enfim, o ato de entrar na caverna e em contato com o procedimento alquímico simboliza, para o protagonista da narrativa, a interiorização psíquica necessária para que o adolescente resolva interiormente o complexo materno e, conseqüentemente, livrese no mundo externo da dependência de proteção. O cumprimento dessa etapa é

${ }^{204}$ CHEVALIER, Jean e GHEERBRANT, Alain. Dicionário de símbolos: mitos, sonhos, costumes, gestos, formas, figures, cores, números. Trad. Vera da Costa e Silva, Raul de Sá Barbosa, Ângela 205 Melim, 
condição sine qua non para que se possa prosseguir no caminho da maturidade, cujo alcance requer ainda o desenvolvimento da consciência sobre a importância de se manter o equilíbrio entre matéria e espírito individuais e universais, sem o que não pode haver indivíduo nem coletividade em harmonia.

Depois de Casemiro ter enxergado Cucura nos olhos do pássaro, as imagens da coruja e da fogueira foram diminuindo e afastando-se de seu campo de visão. No mesmo instante, o garoto virou o rosto para o alto e notou que se aproximava do teto, como se estivesse voando. Vale recuperar o trecho narrativo.

"Será que estou voando de verdade" [pensou Casemiro]. Aquela era a mais fantástica das coisas que tinha experimentado desde que saíra de casa. Parecer um pássaro! Casemiro procurou dirigir seus movimentos, usar os braços como asas. Mas logo se viu perdendo altura, começando a cair. Voltava a enxergar com mais nitidez a fogueira. O chão já chegava perto.

Aí se sentiu puxado pela gola da camisa e voltou a subir. la se mexer para ver quem o levava, quando se sentiu passar através da água. Numa velocidade incrível, tinha saído pelo teto da caverna, atravessado a água do rio, desde o fundo, e ido dar na outra margem. Foi posto em terra por uma gigantesca mão morena. Olhou finalmente para cima e viu Capi. Em torno dele, três outros gigantes de caras conhecidas: Caboré, Cafofo, Cacorê. ${ }^{206}$

A descrição é a imagem representativa das aberturas existentes, como se viu, na abóbada da caverna, no topo do cadinho e do crânio humano. A cena simboliza o renascimento, o despertar da nova consciência, o libertar-se em direção ao cosmo. A saída de Casemiro pelo teto remonta o mito platônico da caverna, que reza a respeito da luz que a alma deve seguir. A travessia para outra margem do rio simboliza a ultrapassagem dos obstáculos que impedia o garoto de escapar do mundo das aparências no qual viviam os homens de Cravo Branco. Indica ainda que ele ultrapassou o mundo fenomenal, que atingiu o estado incondicionado, que se livrou do universo dos sentidos e chegou ao estado de não-vinculação, para além do ser e do não-ser. Explica Eliade ${ }^{207 .}$

${ }^{206}$ O relógio do mundo, pp. 25-6.

${ }^{207}$ ELIADE, Mircea. Mito e realidade. Trad. Pola Civelli. 6.ed., São Paulo, Perspectiva, 2002, p. 76. 
Os mitos e ritos iniciatórios de regressus ad uterum colocam em evidência o seguinte fato: o "retorno à origem" prepara um novo nascimento, mas este não repete o primeiro, o nascimento físico. Especificamente, há uma renascença mística, de ordem espiritual - em outros termos, o acesso a um novo modo de existência (comportando a maturidade sexual, a participação na sacralidade e na cultura; em suma, a "abertura" para o Espírito). A idéia fundamental é que, para se ter acesso a um modo superior de existência, é preciso repetir a gestação e o nascimento, que são porém repetidos ritualmente, simbolicamente; em outros termos, as ações são aqui orientadas para os valores do Espírito e não para os comportamentos da atividade psicofisiológica.

O fato de Casemiro ter sido posto em terra pelo agora gigante Capi, seguido por "três outros gigantes de caras conhecidas" - Caboré, Cafofo, Cacorê —, dá idéia da capacidade de transformação dessas criaturas e da ambigüidade da forma como podem se manifestar. Na função de guardiões do segredo que garante o equilíbrio ambiental; do processo alquímico natural que assegura a continuidade da vida no Planeta, são como os elementais da terra: gnomos conhecedores dos conteúdos ocultos, inconscientes, capazes de iluminar a consciência dos homens. Quando revelados como gigantes representam a potencialidade integral do símbolo gnomos. O gnomo, quando desdobrado em complexo masculino e feminino, simboliza a aliança em todo ser de um lado feio e um lado belo, de um lado mau e um lado bom, de um lado terroso e outro cheio de luz. Trata-se, sem dúvida, de uma imagem dos estados de consciência, complexos e fugidios, em que coexistem ignorância e conhecimento, riqueza e pobreza morais. ${ }^{208}$

O mito dos gigantes é um apelo ao heroísmo humano. O gigante representa tudo aquilo que o homem tem de vencer para libertar e expandir sua personalidade. A evolução da vida no sentido de uma espiritualização é um verdadeiro combate dos gigantes. Mas essa evidência implica um esforço do homem, que não deve contar só com as forças do alto para triunfar de tendências involutivas e regressivas imanentes nele. $^{209}$

Os gigantes indicam a Casemiro o rumo norte. Para orientar-se, ele segue contra a corrente de um outro rio menor, cheio de curvas, que descia do norte. $\mathrm{Na}$

${ }^{208}$ CHEVALIER, Jean e GHEERBRANT, Alain. Dicionário de símbolos: mitos, sonhos, costumes, gestos, formas, figures, cores, números. Trad. Vera da Costa e Silva, Raul de Sá Barbosa, Ângela Melim, Lúcia Melim. Rio de Janeiro, José Olympio, 1988, p. 473.

${ }^{209}$ Idem, ibidem, p. 470. 
simbologia do rio, o remontar do curso das águas significa o retorno à Nascente divina. ${ }^{210}$ A confluência desses dois símbolos (os gigantes e a nascente do rio) demonstra tanto o caráter da natureza humana da personagem, exposta e vulnerável a tendências regressivas, quanto o fato de que o processo de maturidade ainda não se completou. Mesmo depois de ter retornado ao útero, de ter entrado em contato com o conhecimento direto, intuitivo, solar, de ter deixado a alma seguir a luz indireta projetada nas paredes da caverna, de ter atravessado para a outra margem do rio, enfim, de ter passado por um intenso processo de interiorização, mesmo depois disso tudo, falta ao homem ainda, para que possa estar amadurecido, o reencontro com sua centelha divina. Continua-se, portanto, nesse caminhar, sempre sujeito a regressões. Explica Jung ${ }^{211}$ :

[...] a regressão só aparentemente leva de volta à mãe. Esta em verdade é a porta que se abre para o inconsciente, para o "reino das mães". Quem entra por esta porta submete toda a personalidade consciente de seu eu à influência dominadora do inconsciente; ou, se tiver a sensação e ter entrado por engano ou que alguém lhe causará o contratempo de empurrá-lo para dentro, ele se defenderá desesperadamente, sem que sua resistência the traga vantagens. Pois a regressão, se não for dificultada, não estaciona na "mãe", mas regride para além desta, até um assim chamado "eterno-feminino" pré-natal, ao mundo primitivo das possibilidades arquetípicas onde, "envolta por visões de infinitas criaturas", a "divina criança" dorme procurando o despertar de sua consciência. Este filho é o germe do todo que o caracteriza através dos símbolos que lhe são próprios.

Viu-se que Casemiro tem como meta chegar a Cucura, onde reinam desde sempre os mesmo reis, onde nada nem ninguém acabam. A cidade mágica, pois, simboliza o chamado que o rapaz ouve para estabelecer contato com o mundo onde habitam as "infinitas criaturas", onde sua "divina criança" dorme procurando o despertar da consciência.

Mas ele ainda não chegou lá. Por isso, apesar de notar a harmonia da vida do outro lado da margem do rio, de ver enormes quantidades de borboletas de asas

${ }^{210}$ Idem, ibidem, p. 780.

211 JUNG, Carl Gustav. Símbolos da transformação. Trad. Eva Stern. 4.ed., Petrópolis, Vozes, 1986, pp.319-20. 
prateadas, de ouvir o som que elas emitiam, de ver como capivaras, pacas, antas e tatus conviviam em harmonia; apesar de tudo isso, Casemiro ainda sofre influência da formação do meio de onde viera. Ao escutar o pio da coruja novamente, lembra de imediato a voz do pai mandando que ele matasse a ave; pensa no ouro encontrado na caverna e imagina Cravo Branco calçada com o metal precioso. Nesse momento, sente falta da arma, com a qual poderia cumprir a missão de aniquilar o pássaro. Do outro lado do rio, entretanto, depois de ter passado por um rito iniciático, as provações, tanto para avançar no processo total de individuação, quanto no rumo inverso, de retroceder à ignorância inicial, são intensas. Enquanto planeja como apanhar a coruja, Casemiro fere o pé ao tropeçar em uma pedra e é atacado por uma nuvem de mosquito.

A passagem é rica em simbologia. Na psicologia analítica, a pedra representa o self, isto é, a totalidade psíquica. De certa forma, o centro mais íntimo do ser humano é semelhante à pedra, isso porque ela simboliza a existência pura, estando o mais possível distanciada das emoções, sentimentos, fantasias e do pensamento discursivo, racional, do ego. Decorre daí um dos pontos de apoio nos quais está baseado o paralelo que Jung traça entre a alquimia e sua teoria da individuação. No campo do conhecimento alquímico, a idéia da lapis ou minera (mineral) sempre esteve relacionada ao homo altus, isto é, ao grau máximo de elevação alcançado pelo homem, representado por Cristo na alquimia medieval. ${ }^{212} \mathrm{O}$ fato de Casemiro sentir muita dor no dedão do pé por conta da topada na pedra significa que ele não está pronto para integralizar o self. Metaforicamente falando, ocorre algo como se batesse com a cara na porta ainda fechada da totalidade psíquica. A imagem confirma-se pela presença dos mosquitos, cujo símbolo é descrito por Chevalier e Gheerbrant. 213

Um historiador grego da mitologia acha que a famosa esfinge de Tebas, virgem de unhas curvas, de cantos enigmáticos (Sófocles), esse monstro que propunha enigmas aos passantes e os devorava, não era senão o mosquito da malária. O monstro morreu quando Édipo resolveu o enigma secando os pântanos através de um sistema de drenagem [...].

212 JUNG, Carl Gustav. Psicologia e alquimia. Trad. Dora Mariana Ribeiro Ferreira da Silva. 2.ed., Petrópolis, Vozes, 1994, parte III, cap.5, pp. 359-70.

${ }^{213}$ CHEVALIER, Jean e GHEERBRANT, Alain. Dicionário de símbolos: mitos, sonhos, costumes, gestos, formas, figures, cores, números. Trad. Vera da Costa e Silva, Raul de Sá Barbosa, Ângela Melim, Lúcia Melim. Rio de Janeiro, José Olympio, 1988, p. 623. 
De outro lado, o pântano é um dos símbolos do Inconsciente. Este não libera as suas águas mortas que fermentam e multiplicam os mosquitos a não ser que sejam abertos canais; esses canais do inconsciente são as vias de expressão de si mesmo, os sonhos, a palavra, a poesia, a pintura, a música.

Apesar da experiência iniciática, Casemiro ainda não abriu totalmente os canais da percepção, da intuição, não está livre da influência do mundo dos fenômenos e das aparências. Os valores culturais relativos ao ambiente em que fora criado ainda lhe impregna a alma, a razão, o pensamento. A diferença é que, depois de ter entrado na caverna, ele tem uma informação nova: havia sido avisado do que existe para além do aqui e agora da vida mundana. Alguns dos véus da ilusão que Ihe vendavam os olhos espirituais haviam sido retirados e, dessa forma, ele está em condições de decidir por contra própria se quer seguir pelas veredas do ser integral, se quer atingir o self por meio da completude do processo de individuação, ou se quer retroceder e viver mergulhado naquilo que no hinduísmo denomina-se maya, isto é, o mundo de fantasias criado pelos sentidos em relação à matéria, que impede a visão do real.

Pois bem, agora que Casemiro já pode optar, vê se que as forças regressivas exercem pressão sobre sua mente. O rapaz parece determinado a prender a coruja. Como estava sem a arma, faz da camisa uma espécie de rede, com a qual aprisiona a ave. Uma vez capturada a presa, planeja voltar para casa, chamar o pai para, com ele, pegar o ouro da gruta. Nesse momento, a natureza inteira mostra-se ferida de morte, como se profundamente traída depois de revelar seu segredo mais recôndito, fonte vital de todo seu esplendor. Vem o frio, vai-se embora a luz. Casemiro sentese gelado. A vegetação seca, as árvores perdem as folhas. Os bichos interrompem os ruídos. O rio freia seu curso, congela. De repente, o silêncio, o escuro, o nada, a total ausência de vida.

O relógio do mundo começava a desregular e o planeta inteiro definharia, sem calor. Casemiro [junto com a coruja] estava matando o mundo, e junto o próprio sonho de conhecer Cucura. ${ }^{214}$

${ }^{214}$ O relógio do mundo, p. 30. 
Conhecer Cucura, como foi visto, significa alcançar a plenitude do conhecimento intuitivo, condição essencial para tornar-se adulto, evoluído, detentor do potencial máximo da capacidade criativa, da faculdade de reconhecer o princípio uno que habita tudo que é vivo, de respeitar e reverenciar o mistério da Criação. Não se atinge essa meta senão pela preliminar união das polaridades negativas e positivas presentes em todos os seres, representadas pelos princípios masculino e feminino de que é composta toda a existência. Para o pensamento junguiano, essa união dá-se quando animus e anima são devidamente reconhecidos e integrados ao ego. Mas só isso não basta. É preciso também reconhecer e aceitar como parte de si mesmo a presença de um outro forte e poderoso arquétipo, a que Jung deu o nome de sombra. Sombra é a parte inconsciente da personalidade, isto é, compõese dos aspectos da própria natureza que, por várias razões, o indivíduo preferiu não olhar. Configura-se como o receptáculo dos conteúdos psíquicos suprimidos no desenvolvimento da personalidade consciente. Franz ${ }^{215}$ define sombra com bastante clareza:

A sombra não é o todo da personalidade inconsciente: representa qualidades e atributos desconhecidos ou pouco conhecidos do ego aspectos que pertencem sobretudo à esfera pessoal e que poderiam também ser conscientes. Sob certos ângulos a sombra pode, igualmente, consistir de fatores coletivos que brotam de uma fonte situada fora da vida pessoal do indivíduo.

Quando uma pessoa tenta ver sua sombra ela fica consciente (e muitas vezes envergonhada) das tendências e impulsos que nega existirem em si mesma, mas que consegue perfeitamente ver nos outros - coisas como egoísmo, a preguiça mental, a negligência, as fantasias irreais, as intrigas e as tramas, a indiferença e a covardia, o amor excessivo ao dinheiro e aos bens [...].

A partir do momento em que se identifica a sombra como parte da própria psique, o indivíduo passa a "conviver" com ela incessantemente. Todas as vezes que for necessário fazer algum tipo de escolha consciente, o aspecto preterido estará presente como se a sinalizar que poderia ter sido vivido e não o foi. Enfrentar

${ }^{215}$ FRANZ, Marie-Louise von. "O processo de individuação". In: JUNG, Carl Gustav et. alii. O homem e seus símbolos. Trad. Maria Lúcia Pinho. 4.ed., Rio de Janeiro, s/d., p. 168. 
o lado sombrio pode ser bastante sofrido. Pela importância da sombra, vale reforçar a citação de Franz com o que o próprio Jung ${ }^{216}$ diz sobre o arquétipo.

Esta é a primeira prova de coragem no caminho interior, uma prova que basta para afugentar a maioria, pois o encontro consigo mesmo pertence às coisas desagradáveis que evitamos, enquanto pudermos projetar o negativo à nossa volta. Se formos capazes de ver nossa própria sombra, e suportá-la, sabendo que existe, só teríamos resolvido uma pequena parte do problema. Teríamos, pelo menos, trazido à tona o inconsciente pessoal. A sombra, porém, é uma parte viva da personalidade e por isso quer comparecer de alguma forma. Não é possível anulá-la argumentando, ou torná-la inofensiva através da racionalização. [...] Temos porém que reconhecer: há problemas simplesmente insolúveis por nossos próprios meios. Admiti-lo tem a vantagem de tornar-nos verdadeiramente honestos e autênticos. Assim se coloca a base para uma reação compensatória do inconsciente coletivo; em outras palavras, tendemos a dar ouvidos a uma idéia auxiliadora, ou a perceber pensamentos cuja manifestação não permitíamos antes.

A sombra, no entanto, não é apenas depositária de conteúdos negativos e rejeitados. Possui também aspectos positivos que impulsionam o ser humano para a criatividade e busca de soluções, quando os recursos conscientes se esgotaram. Nesse caso, pode surgir em forma de inspiração. A sombra, seja em seu caráter negativo ou positivo, não se deixa reprimir pela consciência. De um jeito ou de outro, ela se manifesta. No enredo de O relógio do mundo, notam-se as manifestações da sombra de Casemiro.

O lado recalcado, por exemplo, representa-se no momento em que o garoto tenta matar a coruja e imagina voltar à floresta para explorar o ouro. É a face assustadora da sombra, aquilo que ele negligenciou em si, isto é, nunca havia prestado atenção no fato de que, por ter nascido em Cravo Branco, por ser filho do capitão Cornélio, tinha as mesmas ambições das pessoas de sua cidade. Conforme notado acima, a sombra pode consistir de fatores coletivos que brotam de uma fonte situada fora da vida pessoal do indivíduo. A paralisação da vida na floresta simboliza o reconhecimento da sombra como parte de si mesmo. Se Casemiro tivesse matado

${ }^{216}$ JUNG, Carl Gustav. Os arquétipos e o inconsciente coletivo. Trad. Maria Luíza Appy e Dora Mariana R. Ferreira da Silva. Petrópolis, Vozes, 2000, p. 31. 
a coruja, teria matado também o princípio feminino dentro de si, e estaria desabilitado a continuar seguindo o caminho da individuação. Isso porque a necessidade de se harmonizar com a anima atua como um dos impulsos para a busca do desenvolvimento. É o equilíbrio dos elementos masculino e feminino animus e anima - na psique que permite ao ser humano atingir a maturidade.

Viu-se como a coruja simboliza o feminino e o conhecimento por reflexo, lunar, isto é, cultural. Quando o garoto tenta e consegue aprisionar a ave, ele detém junto o avanço desse saber racional-teórico, próprio do mundo manifesto. Como conseqüência, a energia solar desvanece, a natureza inteira deixa de existir. Dito de outra forma, sem a consciência também não se enxerga a luz espiritual.

Casemiro fechou os olhos e sentiu o ouro da caverna se tornando fosco, escurecido, um metal sem brilho. ${ }^{217}$

No âmbito do sentido amplo da narrativa, a cena reporta tanto ao discurso ambientalista quanto ao problema crônico da Educação no Brasil. A nãopreservação dos recursos naturais, comprovadamente, causa mudanças climáticas em todo o globo terrestre. Em não havendo radical reversibilidade ou, no mínimo, mitigação dos meios convencionais de geração de energia, cientistas prognosticam um quatro bastante crítico para a saúde do Planeta em médio prazo. Com relação ao sistema educacional brasileiro, a atual situação de decadência em que se encontram tanto as escolas públicas quanto o processo de formação e valorização dos docentes repercute de maneira negativa nos índices de desenvolvimento humano ${ }^{218}$. Como conseqüência, o que se observa é a geração de grupos sociais completamente excluídos da economia de mercado e de uma juventude totalmente entregue à barbárie, isto é, a práticas violentas de convívio, como atestam os noticiários do País nesta primeira década do século XXI.

Voltando à sombra, discutia-se a respeito dos aspectos negativos e positivos dessa na psique de Casemiro. Descreveram-se as características negativas. Comenta-se adiante a natureza positiva. Ao aceitar a sombra, isto é, ao admitir a existência de um problema insolúvel pelos próprios meios, conforme os dizeres acima citados de Jung, o rapaz abre-se para "uma reação compensatória do

${ }^{217}$ O relógio do mundo, p. 30

${ }^{218}$ Sobre essa realidade, ver documentário: PRO DIA nascer feliz. Direção e roteiro: João Jardim. Produção: Flavio R. Tambellini e João Jardim. 88 min. Brasil, 2006. 
inconsciente coletivo", dá ouvidos a "uma idéia auxiliadora". Ele desiste de aprisionar o pássaro.

"Que o capitão me desculpe!" [pensou]. E arrancou o pano que prendia a ave. Sacudiu-se inteiro, com os tremores que percorreram seu corpo dos pés até a cabeça. Ao mesmo tempo, a luz voltava. Viu em sua árvore e em todas as outras renascer o verde. A Natureza não morria mais. ${ }^{219}$

Após ser reconhecida, a sombra deve ser integralizada, tarefa essa nada fácil, como explica Franz ${ }^{220}$ :

O problema teria fácil solução se pudéssemos integrar a sombra na nossa personalidade consciente, tentando apenas ser honestos e usar nossa lucidez. Mas infelizmente esta tentativa nem sempre funciona. Há um impulso de tamanha veemência na nossa sombra que a razão não consegue triunfar. Uma experiência amarga vinda do exterior pode ocasionalmente ajudar. É como se fosse necessário um tijolo cair em nossa cabeça para conseguir deter os ímpetos e impulsos da sombra.

A experiência amarga, vinda do exterior, que Casemiro irá vivenciar é simbolizada pela aparição do Caipora. A personagem folclórica, correlata do Curupira, é registrada por Cascudo ${ }^{221}$ :

[...] De caá, mato e pora, habitante, morador. [...] De defensor de árvores passou a protetor da caça. Em qualquer direção, pelo interior do Brasil, o Caapora-Caipora é um pequeno indígena, escuro, ágil, nu ou usando tanga, fumando cachimbo, doido pela cachaça e pelo fumo, reinando sobre todos os animais e fazendo pacto com os caçadores. [...] No Ceará, além do tipo comum, aparece com a cabeleira hirta, olhos de brasa, cavalgando o porco, caititu, e agitando um galho de japecanga.

219 O relógio do mundo, pp. 30-1.

${ }^{220}$ FRANZ, Marie-Louise von. 'O processo de individuação". In: JUNG, Carl Gustav et. alii. O homem e seus símbolos. Trad. Maria Lúcia Pinho. 4.ed., Rio de Janeiro, s/d., p. 173.

${ }^{221}$ CASCUDO, Luís da Câmara. Dicionário do folclore brasileiro. 11. ed., rev., atual. e ilust., São Paulo, Global, 2002, p. 98. 
O destaque ao tipo cearense de Caipora explica-se por ser o mais próximo ao descrito no texto em estudo. O Caipora de O relógio do mundo surge montado em um porco caititu, cercado por um rebanho deles. Na qualidade de protetor da caça, vem cobrar de Casemiro prestação de contas sobre a tentativa de matar a coruja. Significativo é o fato de o rapaz confundir o Caipora com Cacorê, o mais bravo entre os índios do interior da caverna, sinalizando um contato anterior com a sombra. $O$ Caipora irá julgar o menino. A reprodução da cena é importante para o processo interpretativo.

— Você já está por conta de dois erros — o Caipora falou [...].

- Como dois erros? - Casemiro perguntou.

- O segundo foi confundir o meu nome.

Casemiro admitiu o engano.

— Mas, e o primeiro? - quis saber.

- O primeiro, não sabe? É caçar. É contra os caçadores que eu guerreio. Por isso prendo você.

- Agora quem erra é o amigo - Casemiro retrucou.

- Como é que um caçador me fala assim? - o Caipora, irritado, voltou à sua montaria, desamarrando um tacape, preso no caititu.

- Eu não sou caçador. Eu sou jardineiro.

— Quem me prova que você não está mentindo?

- Eu provo!

Quem falou? Casemiro procurou a voz, acima dele. No mesmo galho de antes, só que livre da sua camisa, estava pousada a coruja. ${ }^{222}$

Apesar de assustador, o Caipora figura como a projeção do lado positivo da sombra de Casemiro. Trata-se de componente da totalidade psíquica do rapaz que vem em seu auxílio, como se a lembrá-lo que, apesar de ser filho do capitão Cornélio, de ter nascido no seio de uma sociedade predadora como a de Cravo Branco, ele não comungava inteiramente dos mesmos valores com seu povo ancestral. Preservava, como todos os seres humanos, certo grau de individualidade com relação ao meio de origem. O fato de ser a coruja quem lhe salva da prisão representa o reconhecimento da sombra. A ave, já se sabe, simboliza a personalidade consciente, que sai fortalecida do embate. Ganhou em lucidez e tornou-se capaz de controlar melhor os ímpetos e impulsos dos conteúdos

${ }^{222}$ O relógio do mundo, pp. 31-2. 
inconscientes. Tanto é que cobra de Casemiro um preço por tê-lo defendido do Caipora.

- Ele tem de renunciar a qualquer desejo de me prender, e assim eu o levo até Cucura - a coruja falou, fixando de novo seu olhar em Casemiro. [...]

- Pois eu renuncio. Prometo não procurar mais apanhar você... Casemiro estava pronto para seguir seu destino. ${ }^{223}$

Não antes, porém, de integralizar de vez a sombra. O Caipora também Ihe faz exigências:

- Mas vai deixar aqui o resto de suas armas! - o Caipora falou.

- Que armas? Perdi a espingarda, o canivete... e nem quis trazer o machado - Casemiro estranhava o pedido.

- Pois daqui pra frente você vai andar nu! Do mesmo modo que qualquer um nesta mata. - E o Caipora soltou uma risada. ${ }^{224}$

Casemiro deve desnudar-se definitivamente dos condicionamentos negativos. Deve despojar-se da ambição desmedida, que coloca em risco tanto o equilíbrio emocional quanto o ambiental. Mais uma vez está presente na narrativa a idéia de humildade. Apenas os princípios de modéstia, respeito, reverência e submissão ante o imenso desconhecido da inconsciência são capazes de abrir caminho ao processo de individuação, que passa pelo desenvolvimento do saber intuitivo. Vencido o julgamento, Casemiro estava pronto para seguir a Cucura, guiado pela coruja. $\mathrm{O}$ rapaz sentia-se envergonhado. Mas não era o castigo imposto pelo Caipora que o fazia sofrer. Já não ligava a mínima para o fato de estar nu. Pensava no ensinamento transmitido por Capi sobre o ouro da gruta. O relógio do mundo, ponto de sustentação da vida, quase havia desregulado. E tudo por culpa dele.

Rumo à cidade mágica, Casemiro não precisava mais seguir o contrafluxo do rio. A coruja havia the ensinado uma trilha. O rapaz tentava conversar com a ave. Perguntava sobre a vida em Cucura, como eram as pessoas de lá. Quis saber mais sobre a companheira, quem era ela. Em seu entender, poderia ser uma criatura encantada, uma fada, talvez. Mas ela respondia laconicamente.

${ }^{223}$ O relógio do mundo, p. 34.

${ }^{224}$ Ibidem, p. 34. 
— Para mim basta ser a coruja, poder falar e guiar você. ${ }^{225}$

Sobre Cucura, o pássaro limitou-se a falar que a cidade era governada por um rei e uma rainha. Daí em diante continuou calada, até o rapaz compreender que nada adiantava informar-se antes do tempo. Uma curiosidade mais forte, no entanto, ainda o inquietava: por que, de toda Cravo Branco, ele tinha de ser o primeiro a ter a chance de ir até Cucura? Tentou mais essa pergunta, mas a coruja havia dormido em seu ombro. A ave confiava nele como agora ele também confiava nela. No silêncio, Casemiro descobriu por si que havia mudado. Não era mais o menino ingênuo, filho do capitão. Era alguém vivendo uma experiência só sua. Não se importava em estar nu, não sentia mais o menor interesse em subtrair o ouro da caverna. Sentia-se amigo da coruja e, para ele, isso era uma constatação da importância da sua contribuição para o fim da guerra e o estabelecimento de uma espécie de aliança entre Cravo Branco e Cucura.

\section{[...] Ele se sentiu suspenso num fio, ligando os dois mundos. ${ }^{226}$}

Retomando a simbologia das figuras mobilizadas na narrativa, tem-se a clara percepção de que o fato de a coruja ensinar a Casemiro uma trilha para chegar à cidade encantada implica o papel fundamental que exerce a consciência, quando ampliada com os conteúdos do inconsciente, para o aceleramento do processo de individuação. Sem o saber teórico, científico, cultural, o indivíduo faz o caminho mais longo, dá muitas voltas, como as do rio que Casemiro, inicialmente, sozinho, havia se proposto a seguir.

O pensamento racional, no entanto, pode atuar de maneira ambígua. Se, por um lado, orienta na direção correta e ajuda a encurtar o caminho, por outro, pode confundir, gerar ansiedade, ilusão, falsas certezas, uma vez que é responsável por construir conhecimento de polaridade negativa, lunar, reflexivo. Dessa forma, a influência da atividade pensante na condução do homem rumo à maturidade deve ser flexibilizada, isto é, a mente deve ser contida em seu ímpeto de tomar sozinha a rédea da direção, sob o risco de perder-se no vozerio da razão. Esse processo é simbolizado no enredo pelo silêncio da coruja. Uma vez indicado o caminho, uma

\footnotetext{
${ }_{225}^{225}$ Ibidem, p. 37.

${ }^{226}$ Ibidem, p. 38.
} 
vez atuado nas grandes bifurcações, uma vez tendo fornecido subsídios para as escolhas mais apropriadas, o raciocínio deve-se aquietar.

A proposição remete à prática da meditação prescrita pelas grandes correntes filosóficas do Oriente, segundo as quais apenas silenciando a mente está o homem apto a ouvir a mensagem do coração ou, nos termos da alquimia, a entrar em contato com a sabedoria que vem de sua caverna interna. O verdadeiro estado de meditação significa ausência da mente. Isto porque é a mente que pensa, analisa, raciocina e distingue o certo do errado, o querer do não querer, o prazer da dor. Portanto, é preciso transcender esse estado analítico para meditar. A particularizarse nos ensinamentos do Yoga, somente livrando-se dos pensamentos está o praticante em condições de fazer ascender pelo sistema nervoso central a energia ígnea da kundalini, que dormita na base da coluna vertebral e cuja subida ao topo da cabeça faz o homem atingir o samādhi, isto é, religar-se ao cosmo e à essência original.

A prática da meditação envolve um processo peculiar e especial de absorção da mente, no qual a atenção é fixada num único objeto. É um processo contínuo em diferentes graus: prānāyāma (abstração dos sentidos), dhāranā (concentração), dhyāna (meditação) e samādhi (integração). Seu princípio básico é o desenvolvimento da percepção interna. ${ }^{227}$

$\mathrm{Na}$ psicologia analítica, faz-se um paralelo entre a prática meditativa e o desenvolvimento do processo de individuação. Por meio de pesquisas, Jung ${ }^{228}$ tentou relacionar o conhecimento do mundo oriental com suas teorias científicas. No depoimento abaixo, o psicólogo parece concordar com o fato de que a mente pensante constitui-se em empecilho para a plenitude do desenvolvimento psíquico:

O Oriente chegou ao conhecimento das coisas internas, com um desconhecimento infantil do mundo. Nós, pelo contrário, exploramos a psique e suas profundezas apoiados num enorme e vasto conhecimento da História e da Ciência. Atualmente, o saber externo é o maior obstáculo à introspecção, mas a necessidade anímica ultrapassará todas as

${ }^{227}$ GULMINI, Lílian Cristina et alii. Estudos sobre o Yoga. São Paulo, CEPEUSP, 2003, p. 64.

228 JUNG, Carl Gustav e WILHELM, Richard. O segredo da flor de ouro: um livro de vida chinês. Trad. Maria Luíza Appy e Dora Mariana R. Ferreira da Silva. Petrópolis, Vozes, 1983, p.56. 
obstruções. Já estamos construindo uma psicologia, uma ciência que nos dará a chave das coisas que o Oriente só descobriu através de estados anímicos excepcionais!

Julga-se importante conhecer ainda a visão de Jung ${ }^{229}$ sobre o que ocorre durante a meditação. Segue outra de suas declarações:

O discípulo é ensinado a concentrar-se na luz da região mais profunda, libertando-se de todos os encadeamentos externos e internos. Sua vontade vital dirige-se então para a consciência vazia de conteúdos, sem que com isso seja anulada a existência de todos os conteúdos. [...]

Esta característica de plenitude ou "plenificação" descreve um estado anímico que talvez se pudesse caracterizar melhor como um desprendimento da consciência em relação ao mundo e como a retirada da mesma para um ponto por assim dizer extramundano. Tal consciência está ao mesmo tempo vazia e não-vazia. Ela não se encontra mais preocupada, preenchida com as imagens das coisas, mas apenas as contém. A abundância anterior do mundo, imediata e premente, nada perdeu de sua riqueza, mas não domina mais a consciência. $\mathrm{O}$ apelo mágico das coisas cessou, porque se desenrolou o entrelaçamento originário da consciência com o mundo. Não sendo o inconsciente mais projetado, desaparece a participation mystique originária com as coisas. Por este motivo, a consciência não é mais dominada por intenções compulsivas, passando a contemplar $[\ldots]$.

Entre as condições primordiais para se enveredar pelo caminho da individuação, como se tem reiteradamente dito, está a necessidade de integrar na psique conteúdos conscientes e inconscientes, razão e emoção, conhecimento teórico e intuitivo, pensamento racional e pensamento mágico. Para tanto, deve-se desprender por alguns instantes do mundo fenomênico, de modo a poder: harmonizar as polaridades do arquétipo puer-senex; integrar os princípios masculino e feminino - animus e anima - , e lançar luz sobre os componentes da sombra. Em O relógio do mundo, esse processo é representado pela necessidade de estabelecer-se a aliança, a interação, o entendimento, o equilíbrio entre as forças de Cravo Branco e Cucura.

${ }^{229}$ Idem, ibidem, pp. 57-8. 
Casemiro está em curso de conhecer a cidade encantada. Em seu caminhar, deve aquietar a ansiedade, afastar de si o desejo de saber antecipadamente o que lá irá encontrar. Trata-se do tipo de conhecimento que não se descreve por nenhuma forma de linguagem humana, produto da mente racional. Como dizem os sábios do Oriente, atingir o samādhi ou o nirvana budista ou, ainda, na psicologia analítica, o processo de individuação, é uma experiência única, pessoal, indescritível. Intuitivamente, Casemiro sabe disso. Veja-se como passa a cuidar da coruja:

[...] Procurou andar com mais cuidado para que ela [a coruja] não acordasse do seu sono. de leve. ${ }^{230}$

— Durma aí, minha amiga, não vou tirar sua paz — murmurou bem

O rapaz estava certo de que passos importantes em direção ao objetivo final ainda deviam ser dados. Sensações a respeito das etapas restantes a serem ultrapassadas chegavam-lhe por intermédio da nostalgia geral persistente e de uma lembrança bem pontual, ambas ilustradas pelo discurso indireto livre do narrador.

Que saudade dos cravos que passara a vida cultivando! E sua mãe, será que ainda a encontraria? ${ }^{231}$

A remissão ao passado, ainda não totalmente transmutado, indica que Casemiro deverá passar por um acerto de contas das ações praticadas pelo povo de sua cidade. Apesar de já ter retornado ao útero, de ter se defrontado com a própria sombra e de ter adquirido certo grau de conhecimento intuitivo, terá de responder pelo carma coletivo dos habitantes de Cravo Branco. A palavra karma vem da raiz sânscrita kri, que significa ação e também o resultado da ação. Explica Hermógenes ${ }^{232}$ :

Avataras e sábios demonstram que cada ação que praticamos no presente tem raízes no passado e se projeta inevitavelmente no futuro Inevitável por quê? Porque não existe causa sem efeito, nem efeito sem

${ }^{230}$ O relógio do mundo, p. 38.

${ }^{231}$ Ibidem, p. 38.

${ }^{232}$ ANDRADE FILHO, José Hermógenes de. O que é Yoga. Rio de Janeiro, Record / Nova Era, 2004, p. 87-8. 
causa. Tal é a "Lei da Causalidade", que desautoriza a crença na casualidade. O que costumamos chamar de forma incorreta de casualidade é uma causalidade, cuja causa escapa à nossa percepção.

Causa e efeito - ensinam os Mestres - não são diferentes. São apenas dois momentos de um mesmo fenômeno. O efeito ou conseqüência já está inseparavelmente entranhado na causa.

No campo da psicologia analítica, o conceito de carma é associado à idéia de herança psíquica e, ainda assim, com muitas reservas. Jung é extremamente cuidadoso ao tratar do tema, que na visão oriental remete à hipótese da reencarnação. Para o psicólogo, é tão impossível conjeturar a respeito de uma possível continuação da psique além da morte quanto provar a existência de Deus. Dessa forma, ele relaciona causa e efeito à sua teoria dos arquétipos. Apesar da citação longa, é importante conhecer o que Jung ${ }^{233}$ pensa sobre o assunto.

[...] o conceito de carma deve ser admitido com prudência, uma vez que o entendemos no sentido amplíssimo de herança psíquica. Existe herança psíquica, isto é, uma herança de peculiaridade psíquica tais como, por exemplo, certas disposições a contrair uma doença, traços do caráter, dotes naturais, etc. São manifestações vitais básicas que se fazem sentir de modo particular no plano da psique, assim como também há peculiaridades hereditárias sensíveis sobretudo ao plano fisiológico, isto é, físico. Mas entre as qualidades psíquicas hereditárias há uma classe particular que não encontra limitações essenciais, nem de ordem familiar, nem no plano racial. São as disposições espirituais de caráter genérico, entre as quais devemos considerar de modo particular um certo tipo de fôrmas, de acordo com as quais o espírito ordena, por assim dizer, os seus conteúdos. Poderíamos chamá-los também de categorias, analogicamente às categorias lógicas que existem sempre e por toda parte, e que constituem os pressupostos essenciais e imprescindíveis do intelecto. Só que no caso das "fôrmas" em apreço não se trata de categorias do intelecto, mas de categorias da faculdade imaginativa. Como os produtos da fantasia são sempre diretamente acessíveis à observação, no sentido mais amplo do termo, suas formas a priori têm o aspecto de imagens, e de imagens típicas, às quais, por essa razão, dei o nome de arquétipos, inspirado na antiguidade clássica.

233 JUNG, Carl Gustav. Psicologia e religião oriental. Trad. Pe. Dom Mateus Ramalho Rocha, O.S.B. São Paulo, Círculo do Livro, 1989, pp. 52-3. 
Apoiando-se nesse raciocínio, pode-se dizer que Casemiro é detentor de herança psíquica de caráter genérico e, por essa razão, deverá pagar um preço pelo legado, nada edificante, recebido do povo de Cravo Branco, ou seja, a tradição de espoliar os recursos naturais da Terra. Sob esse aspecto, o conceito de carma pode aqui ser tomado em sentido muito mais terreno, como exemplifica o próprio Hermógenes ${ }^{234}$. Segundo o filósofo e professor de Yoga, a "Lei da Causalidade" aplica-se até mesmo em casos, como por exemplo, de pessoas fumantes que adoecem e morrem como conseqüência do hábito de fumar. Em O relógio do mundo, o que se vê como conseqüência é uma espécie de resposta da natureza às agressões sofridas por parte dos homens. A forma como Casemiro enfrenta essa causalidade é representada na narrativa pelas provas que ainda tem de passar no momento em que está bem próximo de Cucura.

O rapaz havia caminhado a noite toda. Junto com a madrugada, um vento frio vindo o Oeste enregelava seu corpo. A coruja julgara ser apenas a cruviana, friagem com ou sem neblina própria da madrugada. ${ }^{235}$ Mas a intuição dizia a Casemiro tratar-se de algo mais violento. Ele havia chegado junto a um muro de pedra. Sentia como se tivesse entrado em um labirinto, sem poder voltar atrás. O vento continuava a soprar cada vez mais forte e mais gelado, como uma "lâmina bem fria que penetrava com facilidade sua pele nua e indefesa". ${ }^{236} \mathrm{Um}$ redemoinho de pó levantado do chão o cegava. A coruja parecia cada vez mais longe. A ave tentava gritar algo para ele, como se quisesse ajudar. Mas comunicação entre eles já não se estabelecia mais. O pássaro tinha sumido, voado para longe. O vento era tanto que derrubava Casemiro. O único modo de conseguir continuar andando era colar o corpo ao muro. O rapaz sabia que faltava muito pouco para chegar, que atrás do muro estava Cucura. Por isso, mantinha-se no firme propósito de tatear o muro até encontrar uma porta, uma abertura que fosse. De repente, em meio ao vendaval, Casemiro intuiu a razão da fúria da natureza.

\footnotetext{
${ }^{234}$ ANDRADE FILHO, José Hermógenes de. O que é Yoga. Rio de Janeiro, Record / Nova Era, 2004, p. 88.

235 CASCUDO, Luís da Câmara. Dicionário do folclore brasileiro. 11. ed., rev., atual. e ilust., São Paulo, Global, 2002, p. 166.

${ }^{236}$ O relógio do mundo, p. 40.
} 
Num instante, associou a história da luta entre sua cidade e a floresta com o segredo da gruta. Tantos atos passados haviam afetado o relógio do mundo!

$\mathrm{O}$ vento e o frio tinham sido acordados pelas pessoas de Cravo Branco. Através do fogo, dos golpes de machado, dos tiros, do sangue que correra. Era um sintoma da alteração do ritmo mágico. ${ }^{237}$

A referência às alterações climáticas reais como conseqüência da ação humana - relação de causa e efeito - é evidente. A percepção do rapaz se dá em meio à tormenta, cujo significado bíblico está relacionado a uma intervenção divina e, em especial, à cólera de Deus, manifestada em forma de calamidades vingadoras. ${ }^{238}$ A cena remete à forma como se deu, entre a população do mundo, a tomada de consciência a respeito do aquecimento global. Explica-se: parece que os seres humanos em geral somente se deram conta dos efeitos de sua ação nociva à vida terrestre quando já eram bastante evidentes os sinais de esgotamento do Planeta, quando as médias da temperatura atingiram os maiores níveis de toda história, quando catástrofes naturais foram, finalmente, provadas pelos cientistas como antropogênicas. Relembra-se o fato de que o livro de Lino de Albergaria foi escrito em 1989 e que o relatório mais contundente do IPCC só foi divulgado em 2007. Se, na realidade, os homens conseguirão reverter o problema da devastação ambiental, de modo a oferecerem condições de vida saudável para as futuras gerações, não se sabe. Na ficção de O relógio do mundo, a mensagem é de otimismo.

Assim que associou a fúria da natureza aos atos predadores do povo de Cravo Branco, Casemiro, por meio do tato, encontrou no muro a abertura tão procurada e entrou em Cucura. Deve-se notar como significativo o fato de o rapaz ter de passar por um labirinto. Símbolo de um sistema de defesa, o labirinto anuncia a presença de alguma coisa sagrada. Pode ter uma função militar, como a defesa de um território, uma vila, uma cidade, um túmulo, um tesouro. O centro que o labirinto protege será reservado ao iniciado, àquele que, através das provas da iniciação, se terá mostrado digno de chegar à revelação misteriosa. Quando representativo da evolução individual, o labirinto conduz o homem ao interior de si mesmo, a uma

237 Ibidem, pp. 40-1.

${ }^{238}$ CHEVALIER, Jean e GHEERBRANT, Alain. Dicionário de símbolos: mitos, sonhos, costumes, gestos, formas, figures, cores, números. Trad. Vera da Costa e Silva, Raul de Sá Barbosa, Ângela Melim, Lúcia Melim. Rio de Janeiro, José Olympio, 1988, p. 887. 
espécie de santuário interior e escondido, no qual reside o mais misterioso da pessoa humana. ${ }^{239}$ No texto em estudo, o labirinto confirma o caráter sagrado da cidade, e a passagem por ele sinaliza a conclusão do processo iniciático. Vencido o obstáculo, Casemiro deparou-se com um guarda vestindo um manto colorido. Por meio da conversa entre eles, percebe-se que o rapaz havia crescido fisicamente e que, sobre a pele do rosto, crescia uma barba escura. Ele havia se tornado um homem. A coruja reaparece e o guarda libera a entrada.

- Bem vindo a Cucura! ${ }^{240}$

A cidade mágica é descrita como um conjunto de construções terminadas em torres. Até a revelação bíblica, que perverteu a simbologia da Torre de Babel, a torre sempre representou a "porta do céu". A construção de uma torre tinha como objetivo restabelecer por meio de um artifício o eixo primordial rompido e, por ele, elevar-se até a morada dos deuses. Em sentido amplo, a torre é um símbolo de ascensão em diversas tradições, inclusive na cristã. $\mathrm{O}$ atanor, forno dos alquimistas, tem a forma de uma torre para significar que as transmutações procuradas nas suas operações encaminham-se todas no sentido de uma elevação: do chumbo ao ouro e, no sentido simbólico, do peso carnal à pura espiritualização. ${ }^{241}$

Cucura reúne, pois, diversos símbolos relacionados à ascensão espiritual do homem, os quais também podem ser associados à conquista da maturidade ou, nos termos da psicologia analítica, ao cumprimento do processo de individuação. A associação da torre com o forno alquímico leva ao estabelecimento de uma ligação da cidade com essa prática. A relação confirma-se quando se descobre que o trono dos reis de Cucura localiza-se abaixo da terra, reportando à caverna na qual Casemiro havia caído.

Casemiro completa a descida. E se vê pisando um chão dourado, feito das mesmas pedras - mas agora todas são amarelas como as paredes. É uma sala ampla, certamente evocando a gruta do ouro. No

${ }^{239}$ Idem, ibidem, pp. 530-1.

${ }^{240}$ O relógio do mundo, p. 42.

${ }^{241}$ CHEVALIER, Jean e GHEERBRANT, Alain. Dicionário de símbolos: mitos, sonhos, costumes, gestos, formas, figures, cores, números. Trad. Vera da Costa e Silva, Raul de Sá Barbosa, Ângela Melim, Lúcia Melim. Rio de Janeiro, José Olympio, 1988, pp. 888-9. 
centro, duas cadeiras de prata. Muitas borboletas, de asas prateadas, brincam em torno do casal que ocupa os tronos. ${ }^{242}$

Outro índice relativo à alquimia é o jardim de flores brancas, localizado acima do salão real. Descreveu-se anteriormente a flor como representativa do princípio passivo. Mas as qualidades simbólicas da flor vão muito além. O simbolismo tântrico-taoista da Flor de Ouro, por exemplo, é o do atingir de um estado espiritual. Nesse caso, a floração seria o resultado de uma alquimia interior da união da essência e do sopro, da água e do fogo; seria também o retorno ao centro, à unidade, ao estado primordial. ${ }^{243}$ A cor branca das flores reforça ainda mais a superposição de símbolos.

Assim como o negro, sua contracor, o branco pode situar-se nas duas extremidades da gama cromática. Absoluto - e não tendo outras variações a não ser aquelas que vão do fosco ao brilhante - ele significa ora a ausência, ora a soma das cores. Assim, coloca-se às vezes no início e, outras vezes, no término da vida diurna e do mundo manifesto, o que the confere um valor ideal, assintótico. Mas o término da vida - o momento da morte - é também um momento transitório, situado no ponto de junção do visível e do invisível e, portanto, é um outro início. O branco - candidus é a cor do candidato, i.e., daquele que vai mudar de condição. ${ }^{244}$

Além de compor o nome da cidade não-mágica, ambiciosa, a cor branca é aderente ao protagonista. Cravos brancos aparecem no início, no jardim de Casemiro, e reaparecem no final, nos jardins de Cucura, em referência clara ao processo de morte-renascimento, pelo qual, como se tem acompanhado, a personagem passa. O término, ou seja, a chegada a Cucura, é junção, um outro início. No espaço entre um ponto e outro, "no durante", o que se tem é o processo de transmutação. Aquilo que era volta a ser novamente, a partir de outras bases. Aquele que aspira a vivenciar o processo é o candidato à transformação, daí estar associado ao branco.

${ }^{242}$ O relógio do mundo, pp. 44-5.

${ }^{243}$ CHEVALIER, Jean e GHEERBRANT, Alain. Dicionário de símbolos: mitos, sonhos, costumes, gestos, formas, figures, cores, números. Trad. Vera da Costa e Silva, Raul de Sá Barbosa, Ângela Melim, Lúcia Melim. Rio de Janeiro, José Olympio, 1988, p. 437.

${ }^{244}$ Idem, ibidem, p. 141. 
Casemiro é o candidato. Por isso, está associado ao branco. O significado de seu nome - Casemiro, o instituidor da paz; Correia, o vigoroso - é indicativo de seu destemor, de sua predisposição a passar pelo processo de renascimento, de estabelecer a paz entre as duas cidades. Lembra-se que Casemiro é originário de uma localidade que carrega "branco" no nome. Portanto, Cravo Branco é uma comunidade também candidata a reiniciar um ciclo de vida baseado em uma nova consciência, mais evoluída.

Voltando à cena do encontro de Casemiro com os reis de Cucura, notou-se que muitas borboletas de asas prateadas brincavam em torno do casal. Retoma-se e amplia-se o simbolismo da borboleta, já abordado. Símbolo do fogo solar e diurno, a borboleta representa também o fogo ctoniano ${ }^{245}$ oculto, ligado à noção de sacrifício, de morte e ressurreição.

Um apólogo dos balubas e dos luluas do Kasai (Zaire central) ilustra ao mesmo tempo a analogia alma-borboleta e a passagem do símbolo à imagem. O homem, dizem eles, segue, da vida à morte, o ciclo da borboleta: ele é, na sua infância, uma pequena lagarta, uma grande lagarta na sua maturidade; ele se transforma em crisálida na sua velhice; seu túmulo é o casulo de onde sai a sua alma que voa sob a forma de uma borboleta; a postura de ovos dessa borboleta é a expressão de sua reencarnação. ${ }^{246}$

Como se nota, é reincidente no todo significativo que se constitui o texto de $O$ relógio do mundo a idéia de morte-renascimento. Devido aos atributos simbólicos da borboleta, ela pontua toda a trajetória de Casemiro: voeja em torno dele logo no princípio (p.7); aparece no sonho da capitã (p.11); acompanha o protagonista em diversas situações no interior da floresta (pp. 14, 15 e 17), e somente se afasta quando cai um temporal (p.18). Pode-se dizer que o inseto constitui o índice, o sinal, de que Casemiro teria de desenvolver a capacidade de adquirir conhecimento por vias sensoriais, isto é, deveria abrir-se para a sabedoria direta, intuitiva, representada pela luz do Sol, uma vez que a borboleta, por um lado, está relacionada ao fogo solar, diurno. Porém, abrir os canais perceptivos para esse tipo

${ }^{245}$ Do grego Chton, a Terra. No contexto, representa a chama interior, a centelha divina presente no coração dos homens, isto é, aquilo que é imortal no homem.

${ }^{246}$ CHEVALIER, Jean e GHEERBRANT, Alain. Dicionário de símbolos: mitos, sonhos, costumes, gestos, formas, figures, cores, números. Trad. Vera da Costa e Silva, Raul de Sá Barbosa, Ângela Melim, Lúcia Melim. Rio de Janeiro, José Olympio, 1988, p. 139. 
de conhecimento é algo que só se pode fazer por intermédio do processo simbólico de morte-renascimento, representado pelo despertar do fogo oculto ctoniano, do qual a borboleta também é símbolo. Viu-se como Casemiro foi levado para o interior da caverna, onde os índios o fizeram olhar para as chamas de uma fogueira. Essa fogueira acesa no interior da caverna é, pois, o próprio fogo ctoniano, ligado à noção de sacrifício, morte e ressurreição.

Devem-se acrescentar ainda algumas observações sobre o fato de a borboleta ser prateada, como estranha a capitã.

Camélia viu o inseto em torno do filho e lhe veio um estranho pressentimento. Borboletas claras - amarelas ou brancas - são as que trazem boa sorte. Borboletas escuras, marrons e cinzentas anunciam dificuldades. Mas o que significava uma borboleta cor de prata? ${ }^{247}$

Já se falou do princípio de pureza que a prata representa. Complementa-se a simbologia do metal com a seguinte citação de Chevalier e Gheerbrant. ${ }^{248}$

A própria palavra latina argentum deriva de um vocábulo sânscrito que significa branco e brilhante. Assim, não será motivo de surpresa ver-se esse metal ligado à dignidade real.

Associa-se dessa forma a borboleta prata à própria dignidade e à pureza dos reis de Cucura e, por conseguinte, de toda a civilização que habita a cidade encantada. Fácil é dizer que a borboleta prata é, desde o início, o símbolo principal de Cucura, espécie de arauto da cidade com a missão de chamar Casemiro. Mas o valor simbólico do inseto para o enredo é mais complexo. Notou-se antes que a borboleta representa os dois fogos: o diurno-solar e o oculto-noturno. Sob esse aspecto traz em si o princípio masculino, ativo, que reporta ao conhecimento direto, instintivo. Em sendo prata, essa borboleta também está associada ao princípio feminino, passivo, que remete ao conhecimento indireto, por reflexo, teórico. Portanto, a borboleta de $O$ relógio do mundo une em si as polaridades: masculinofeminino, ativo-passivo, intuição-razão. Na psicologia analítica, essa união de

${ }^{247}$ O relógio do mundo, p. 8.

${ }^{248}$ CHEVALIER, Jean e GHEERBRANT, Alain. Dicionário de símbolos: mitos, sonhos, costumes, gestos, formas, figures, cores, números. Trad. Vera da Costa e Silva, Raul de Sá Barbosa, Ângela Melim, Lúcia Melim. Rio de Janeiro, José Olympio, 1988, p. 739. 
opostos é referida como a integralização da personalidade, ou self, por meio do intercâmbio constante entre conteúdos conscientes e inconscientes, entre luz e sombra, entre anima e animus. Deve-se lembrar que, depois de ter sumido quando Casemiro cai na caverna, a borboleta prata volta a aparecer no momento em que o rapaz é colocado na outra margem do rio. Dessa vez, não só uma, mas muitas borboletas pratas. Elas também são numerosas na sala do trono dos reis de Cucura, conforme já demonstrado. Nota-se, assim, que o símbolo é mobilizado para revestir a idéia abstrata de evolução psíquica e intelectual com a figura do casal real da cidade encantada. A interpretação é confirmada por meio da seguinte descrição:

O rei e a rainha de Cucura não são mais jovens e também não parecem velhos. Dizem as histórias que eles não têm mais idade, e vivem há centenas de séculos. [...] Casemiro reconhece a coruja pousada no ombro do rei. ${ }^{249}$

Quem não é mais jovem, mas também não parece velho, é o ser na plenitude da maturidade, no ápice do vigor físico, da capacidade produtiva, da argúcia intelectiva, da lucidez cognitiva. Os reis de Cucura, eternizados nessa condição, representam o homem cujo desenvolvimento psíquico atingiu o self, isto é, completou o processo de individuação. Vale observar que a presença da coruja no ombro do rei Caruani revela a importância que se dá naquela cidade ao conhecimento racional, teórico-científico, cujo registro compõe o patrimônio cultural de uma coletividade. Leia-se o seguinte trecho:

[...] o rei levantou do trono e caminhou até uma mesa alta, sobre a qual havia um livro, em cuja capa de couro estava gravada apenas uma letra "C". A coruja foi até Casemiro e explicou que aquele livro mágico continha informações sobre tudo o que começa com aquela letra. Inclusive sobre a vida das pessoas com aquela inicial. ${ }^{250}$

É nesse livro que Casemiro fica sabendo o significado de seu nome e sobrenome. Em seguida, Caruani explica ao rapaz as razões de ter sido ele o escolhido entre todo o povo de Cravo Branco para conhecer Cucura. O sentido do

249 O relógio do mundo, p. 45.

250 Ibidem, p. 45. 
nome Casemiro já era uma prerrogativa, sem dúvida, mas ele não teria chegado à cidade mágica se não houvesse cuidado dos jardins, se não houvesse se recusado a agredir a floresta, se não houvesse vencido o desejo de se apoderar da coruja, se não houvesse entendido a função do ouro na gruta, se não houvesse enfrentado sozinho o vento e o frio mortais para encontrar o caminho. Enfim, o que o rei sintetiza de modo figurativo, simbólico, são as etapas fundamentais que todo homem deve passar para se transformar num ser adulto.

Casemiro pergunta a Caruani porque ele, com todo seu poder, capaz de, com apenas um ato de vontade, destruir Cravo Branco, não havia optado por essa forma de resolução do problema. Caruani responde que, se Cravo Branco acabasse, Cucura também sucumbiria. A lição é clara e se conjuga a todos os símbolos mobilizados para representar a evolução do processo individual de Casemiro. Não pode haver evolução psíquica, espiritual, sem evolução intelectual, num contexto em que espírito seja compreendido como o lado mágico, instintivo, intuitivo da existência, e intelecto represente o desenvolvimento material. Matéria e espírito (este no sentido de totalidade psíquica) fazem parte de um todo único de existência. Nem uma parte nem outra podem arvorar-se a ter a supremacia do comando da vida.

A narrativa abre ainda a possibilidade para a interpretação de que a espiritualidade sempre persiste, pois, por meio do diálogo entre Casemiro e o rei, fica-se sabendo que, caso Cravo Branco desaparecesse, Cucura assumiria uma forma imaterial de existência, iria "para dentro do tempo, para dentro de alguma dobra do avesso mundo....". ${ }^{251}$

- E nunca haveria jeito de encontrar vocês? [pergunta Casemiro].

- Não, a menos que permanecessem na fronteira dos dois mundos algumas dessas borboletas ou a nossa coruja... E que alguém, entre vocês, se interessasse por elas... ${ }^{252}$

Deduz-se do diálogo que os homens das sociedades comuns, materialistas, ao destruírem o meio ambiente, correm o risco de perder indefinidamente o contato com seus conteúdos inconscientes. Sob esse aspecto, o interesse de Cucura em garantir a integridade do ouro e da floresta apresenta duplo sentido: preservar o 
equilíbrio dos reinos mineral, vegetal e animal do Planeta é também preservar o equilíbrio da natureza psíquica humana.

No plano coletivo, essa é a missão de Casemiro. Individualmente, pode-se dizer que, em Caruani, ele encontrou um referencial masculino, o tipo de homem que, inconscientemente, havia projetado a ser: poderoso, porém, justo, honesto, generoso, preocupado com o bem-estar de seu povo. Para encontrar esse modelo, um tanto quanto diferente daquele que podia obter por intermédio do pai, precisou passar pelo ritual de morte e ressurreição, teve de enfrentar a própria sombra, submeteu-se a um violento processo de transmutação. No dizer de Hillman ${ }^{253}$, Casemiro tornou-se consciente do senex em todo o seu significado arquetípico e o relacionou a fenomenologia do puer, como se explica na citação:

[...] Nosso tempo e seu anseio de ser curado pede que as duas extremidades [puer-senex] mantenham-se juntas, que nossa outra metade tão próxima de nós, tão igual a nós como a sombra que projetamos, entre no círculo de nossa luz. Nossa outra metade não é apenas de outro sexo. A união dos opostos - masculino e feminino - não é a única a que aspiramos e não é a única união que redime. Há também a união dos iguais, a reunião do eixo vertical que curaria o espírito cindido. Adão precisa reunir-se com Eva, mas ainda fica faltando sua re-união com Deus. Ainda fica faltando a união do primeiro Adão do começo com o segundo Adão no final da história. Essa divisão, experimentada como a cisão egoSelf e o hiato entre a consciência e o inconsciente, está em cada um de nós no coração não curado do processo de individuação.

O encontro com Caruani é o sinal de que Casemiro uniu em sua psique as duas extremidades puer e senex. Entretanto, seu amadurecimento não está completo. Após a conversa com o rei, apesar de ter chegado a Cucura, ainda sentia certo vazio. O que lhe faltava para completar a integridade de sua psique era a união dos elementos masculino e feminino. Nesse momento pensou nas moças que o haviam recepcionado na cidade mágica, que brincaram com ele, que cheiraram seu pescoço e lhe fizeram cócegas. Como diz o narrador, a "idade do amor havia chegado para ele". 254

\footnotetext{
${ }^{253}$ HILLMAN, James. O livro do 'puer': ensaios sobre o arquétipo do 'puer aeternus'. Trad. Gustavo Barcellos. São Paulo, Paulus, 1998, p. 55.

${ }^{254}$ O relógio do mundo, p. 48.
} 
Naquele momento, Coaraci, a rainha, carregando a coruja pousada no dorso da mão, convidou Casemiro para subir à torre mais alta da cidade. Lá em cima, durante o diálogo que mantém com a rainha, nota-se a projeção da anima do rapaz, agora feito homem. Casemiro confessa a Coaraci que havia pensado que a coruja fosse uma princesa encantada. Tendo como referencial masculino-adulto-senex um rei, espécie de pai idealizado, certamente imaginava para si casar-se com uma princesa. Foi essa a imagem feminina que se formou em sua psique. Porém, uma princesa não condiz com a origem comum de Casemiro, e Coaraci busca fazê-lo entender essa realidade. Significativo é o fato de esse diálogo ser travado no alto de uma torre, que também é símbolo do orgulho humano, da tentativa do homem de subir à altura da divindade. ${ }^{255}$ A rainha pergunta se ele quer ver o futuro, esclarecendo que os olhos da coruja poderiam lhe mostrar. Havia, no entanto, uma condição: se quisesse ver o futuro, fatalmente veria também o presente. Assim ocorre. Ele olha atentamente dentro dos olhos da coruja e vê a floresta invadindo e praticamente destruindo Cravo Branco.

Viu a mata, além do horizonte. Viu árvores cercando o flanco de uma cidade. Muros se desmanchando, o mato destruindo os jardins, casas escuras de tanta umidade, pouca gente nas ruas. Procurou sua casa, e ela estava vazia. Pensou na mãe, e viu a capitã debruçada num túmulo. Ela colocava sobre a pedra um pequeno cravo branco. Casemiro compreendeu que o capitão se fora. ${ }^{256}$

Amparando sua mãe junto à sepultura, Casemiro viu uma garota. Era Cordélia Camarão, vizinha dos Correia, magra e pálida, como ele mesmo tinha sido antes de empreender a viagem. Casemiro mostra-se decepcionado. Vê ruir por terra o sonho de casar-se com uma princesa. Esse é mais um dos desafios que terá de enfrentar. Deve aprender a controlar o orgulho por ter evoluído sozinho. Precisa entrar em acordo com o elemento feminino dentro de si. A anima que traz introjetada é exigente demais, não se contenta em ser menos do que princesa. Coaraci insiste com ele para que continue olhando os olhos da coruja. Casemiro viu Cordélia conduzindo sua mãe de volta para casa. Os olhos da jovem, inquietos, olhavam em

${ }^{255}$ CHEVALIER, Jean e GHEERBRANT, Alain. Dicionário de símbolos: mitos, sonhos, costumes, gestos, formas, figures, cores, números. Trad. Vera da Costa e Silva, Raul de Sá Barbosa, Ângela Melim, Lúcia Melim Rio de Janeiro, José Olympio, 1988, p. 889.

${ }^{256}$ O relógio do mundo, p. 49. 
volta. Até que uma borboleta prateada apareceu ao lado da moça, simbolizando promessa de evolução. Nesse momento, o rei chega à torre e dirige-se a Casemiro.

\footnotetext{
- Você não acha que Cucura e Cravo Branco podem conviver em paz? - Caruani perguntou, num tom bem mais alegre do que tinha usado lá embaixo.

- Por que não? - Casemiro também perguntou, já dando sua resposta.

- Agora eu até acredito nisso - disse o rei. - Pois você é o novo capitão Correia. ${ }^{257}$
}

Antes de retornar a Cravo Branco, Casemiro precisará de um tempo para refletir sobre o que seria sua vida dali em diante. Desvanece de seus pensamentos a possibilidade de ficar em Cucura. Ao comparar-se com os rapazes e moças da cidade encantada, sente alguma tristeza por não ser igual a eles. A morte de seu pai também lhe causava certo vazio. Sabia da responsabilidade que o aguardava. Como capitão Casemiro Correia tinha a missão de estabelecer a paz entre os dois reinos. Afinal, era este o significado de seu nome: o instituidor da paz. Além disso, sentia a obrigação de rever e consolar a mãe, de levar à capitã a alegria que ela já não esperava mais ter. Apenas não tinha digerido ainda a idéia de esposar Cordélia Camarão. Nunca havia se interessado por ela. De todo modo, não se sentia obrigado a casar. Pensava mais na mãe e na possibilidade de restaurar a vida em Cravo Branco. Assim determinado, despediu-se dos reis de Cucura.

Casemiro retorna pela floresta. Pelo caminho, nota-se a ratificação de seu processo iniciático. Percebe-se que o complexo da sombra destruidora da natureza foi dominado, conforme trecho abaixo:

Durante algum tempo, sentiu-se acompanhado por uma sombra. Era o Caipora, decerto intrigado com o manto branco de Casemiro, manto tecido em Cucura. [...] O Caipora, não sentindo hostilidade no viajante, deixou de segui-lo. ${ }^{258}$

A sombra, pelo menos aquela, deixava de ser um obstáculo para o processo de individuação. Que o renascimento também havia se processado por inteiro é algo

\footnotetext{
${ }^{257}$ Ibidem, p. 51.

${ }^{258}$ Ibidem, p. 55.
} 
que se pode observar no reencontro com os índios habitantes da caverna. O agora homem Casemiro tem de atravessar o rio de volta, para chegar a Cravo Branco. Das águas, emergem Caboré, Cafofo e Cacorê. Este último cobra do rapaz o juramento de que não vai mais pensar no ouro. Casemiro não precisa jurar. Está claro que, dali em diante, será o quinto guardião do relógio do mundo. Surge então Capi, em forma de gigante, e o coloca na outra margem do rio. Tudo no trajeto confirmava a propriedade dos passos dados pela personagem rumo ao desenvolvimento psíquico. Mas a tarefa não estava totalmente completada.

A resistência de Casemiro em entender que Cordélia era mulher com quem devia se unir era o sinal de que faltava resolver, ainda, a questão do feminino introjetado. Em outras palavras, Casemiro precisava liberar a anima como componente íntimo da psique. No dizer de Henderson ${ }^{259}$, Casemiro precisava "encontrar um meio de libertar a energia psíquica ligada à relação mãe-filho, de maneira a alcançar um relacionamento mais adulto com as mulheres". Na psicologia analítica, a resolução desse conflito é representada pelo mito do herói que enfrenta o monstro e salva a donzela. É ainda Henderson ${ }^{260}$ quem explica:

Na luta travada pelo homem primitivo para alcançar a consciência, este conflito se exprime pela disputa entre o herói arquetípico e os poderes cósmicos do mal, personificado por dragões e outros monstros. No decorrer do desenvolvimento da consciência individual, a figura do herói é o meio simbólico através do qual o ego emergente vence a inércia do inconsciente, liberando o homem amadurecido do desejo regressivo de uma volta ao estado de bem-aventurança da infância, em mundo dominado por sua mãe.

De acordo com essa teoria, para que o homem possa estabelecer uma relação amadurecida com as mulheres, é necessário que ele resolva aquilo que, no pensamento junguiano, se dá o nome de "complexo materno", como já foi visto. Hillman, no entanto, em seus estudos que buscam avançar no campo das idéias de Jung, acredita que o fenômeno puer deva ser removido da figura da mãe, e que, ao invés de enfrentá-la, como simboliza o mito tradicional do herói, o homem deve

\footnotetext{
${ }^{259}$ HENDERSON, Joseph L. "Os mitos antigos e o homem moderno". In: JUNG, Carl Gustav et. alii. 0 homem e seus símbolos. Trad. Maria Lúcia Pinho. 4.ed., Rio de Janeiro, s/d., p. 125.

${ }^{260}$ Idem, ibidem, p. 116.
} 
redimi-la. Esclarecendo melhor, Hillman ${ }^{261}$ não concebe os problemas do puer aeternus como sendo causados pela mãe nem vinculados a ela, conforme ele mesmo explica ao falar do processo de maturidade:

O cosmo em que colocamos a juventude e através do qual tentamos compreendê-la influencia seus modelos de formação. Da perspectiva da mãe, o jovem associa-se ao feminino como consorte, é parte integrante de sua fertilidade e crescimento natural, de seu impulso à cultura heróica e de seu reino da morte. Da perspectiva do senex, o jovem é renovação, como esperança ou como ameaça, o idêntico e o diverso em uma só figura, uma dinâmica que requer ordem, uma inocência pedindo conhecimento e uma possibilidade a ser realizada através do tempo e do trabalho.

Embora essas duas visões de juventude descrevam tipos de consciência, não precisamos fazer uma hierarquia desses tipos, para demonstrar que matriarcado é anterior a patriarcado ou que filho, herói e puer refletem níveis de desenvolvimento. Níveis de consciência implicam progresso. Eles desprendem da mãe e da matéria o heroísmo espiritual do autodesenvolvimento e o impelem à iluminação. [...] A procura das origens tem de conduzir de volta à mãe, de qualquer maneira, que deve sempre vir "primeiro", uma vez que a análise genética, ou análise em termos de origens, é obediência a ela, sendo determinada pelo seu tipo de consciência.

Ao lembrar-se que hoje muitos dos modelos familiares fogem ao tradicional, e que a figura materna, a partir do processo de emancipação feminina, não se caracteriza mais como a única referência no cotidiano do lar, os aspectos devoradores do animus maternos talvez estejam, neste começo século XXI, bastante amenizados, embora esse não seja o caso de Camélia Correia, a mãe de Casemiro, como já se comentou. De todo modo, Hillman não desconsidera a necessidade de se resolver com a mãe os problemas do homem relacionados ao amadurecimento. Ao contrário, como se observa na citação, ele reafirma que a procura das origens tem de conduzir de volta à mãe. A diferença entre sua proposição e a dos demais seguidores de Jung é a de que a resolução do complexo materno não se dá por meio do combate e, sim, pela harmonização com a mãe e

${ }^{261}$ HILLMAN, James. O livro do 'puer': ensaios sobre o arquétipo do 'puer aeternus'. Trad. Gustavo Barcellos. São Paulo, Paulus, 1998, p. 96. 
pela compreensão de que o problema do puer existe por si, como polaridade isolada do arquétipo integral puer-senex. Em vez de matar o dragão, o herói deve harmonizar-se com ele.

Casemiro retorna à mãe. Irá encontrá-la cochilando na varanda, sentada à cadeira de balanço. Havia passado a noite inteira ali.

— Mãe? - Com cuidado, o homem acordava a velha.

Camélia Correia não se assustou com o estranho. Logo adivinhou quem ele era.

- Casemiro! - a voz da velha era parte de seu sorriso.

Ainda tendo a capitã dentro dos seus braços, o homem olhou para o outro lado da rua. E seu olhar cruzou com o da mulher. Ela era forte e usava os cabelos como os usa uma rainha... ${ }^{262}$

A mulher era Cordélia. Na noite anterior, após deixar Camélia em casa, a garota magra e franzina havia ido se deitar. No limiar entre estar acordada e o começo de um sonho, imaginou ter visto uma borboleta prateada. No mesmo instante, um forte clarão lunar invadiu todo o quarto. Cordélia levantou-se da cama, foi para o jardim e viu várias flores brotando da terra ao mesmo tempo. Flores também nasciam por toda a parte, enfeitando a cidade inteira. Ao acordar, a moça foi olhar-se no espelho.

Ela se sentiu corada, mais disposta do que nunca. Penteou os cabelos e fez com eles uma trança. Sem saber por quê, se achou parecida com uma rainha. Ou, quem sabe, uma princesa...

Abriu a porta da casa e viu quando ele chegou. ${ }^{263}$

Pode-se aludir aqui ao fato de o percurso narrativo de Cordélia Camarão ocorrer, de certo modo, paralelo ao de Casemiro Correia. Embora as etapas de transformação da personagem não sejam explicitamente narradas, infere-se que, simultaneamente ao protagonista, a garota tenha vivenciado o rito de passagem sem nunca ter abandonado Cravo Branco.

Como se nota, o reencontro de Casemiro com a mãe e com sua futura mulher dá-se ao mesmo tempo. A correspondência é evidente: ao retornar amadurecido, 
completamente diferente do Amarelinho, meio medroso e indefeso, que abdicara da proteção materna três anos antes, e postar-se diante da mãe como homem feito, barbado, destemido, pronto a amparar-Ihe no que fosse preciso, Casemiro conciliase com o arquétipo da anima. Da perspectiva da mãe, ele associa-se ao feminino como consorte. Além disso, ao reaparecer transformado, na condição de novo capitão de Cravo Branco, trouxe novamente a vida para toda a cidade. Ninguém melhor do que Hillman para dar suporte à interpretação dos momentos finais de $O$ relógio do mundo.

[...] o trabalho analítico nos níveis coletivos da alma é tão "heróico". Mudanças psicológicas - mudanças de atitude, mudanças de personalidade, aquelas fundamentais ilustrações da alma - são também regenerações da história. Transformar as atitudes de minha família ao desnudar padrões nas emaranhadas raízes ancestrais não é meramente problema analítico pessoal. É passo histórico rumo a libertar uma geração do padrão coletivo. Ao modificar esse padrão coletivo, há mudança na própria história. E cada um, qualquer um que abre uma clareira no seu pedaço de floresta do passado é o herói que redime o tempo e o bode expiatório que, ao tomar para si os pecados, desfaz o tempo. ${ }^{264}$

É, portanto, repleto de mensagens otimistas que se encerra o texto de $O$ relógio do mundo. Cravo Branco renasce como renasceu Casemiro. As casas velhas da cidade são recuperadas do mofo e brilham de novo à luz do Sol. Para o bemestar da mãe Natureza, é restabelecida a harmonia entre os reinos vegetal, animal e mineral. Casemiro e Cordélia tiveram 12 filhos: seis meninos e seis meninas. O mais novo deles, Calisto Correia, gosta de cuidar dos jardins e passear sozinho pela mata. Todos em Cravo Branco sabem, embora não gostem de comentar, que do outro lado da floresta, existe uma cidade encantada, chamada Cucura. Oxalá os homens do mundo se lembrassem de que uma "Jerusalém celestial foi criada por Deus antes que a cidade fosse construída pela mão do homem". ${ }^{265}$

${ }^{264}$ HILLMAN, James. O livro do 'puer': ensaios sobre o arquétipo do 'puer aeternus'. Trad. Gustavo Barcellos. São Paulo, Paulus, 1998, p. 19.

${ }^{265}$ ELIADE, Mircea. Mito do eterno retorno. Trad. José Antonio Ceschin. São Paulo, Mercuryo, 1992, p. 20. 


\section{4. $O$ rito de passagem em tempo e lugar diferentes}

Embora a conquista da maturidade seja um processo de natureza psíquica, ou seja, de característica universal e atemporal, o modo como o ser adulto se expressa no mundo está diretamente relacionado com a forma de organização social do tempo e lugar em que vive o indivíduo. Por essa razão, julgou-se por bem estabelecer um paralelo entre $O$ relógio do mundo e outra obra de língua portuguesa cuja construção narrativa, de maneira similar à de Lino de Albergaria, fosse estruturada a partir da representação do mito do herói e daquilo que ele expressa referentemente ao processo de passagem da adolescência para a vida adulta. Com essa finalidade, optou-se por Aventuras de João Sem Medo: panfleto mágico em forma de romance ${ }^{266}$, de José Gomes Ferreira, produzida em época, lugar e contexto sócio-cultural diferenciados.

José Gomes Ferreira nasceu na cidade do Porto, em 1900, e faleceu em 1985. Formou-se em Direito, na Faculdade de Direito de Lisboa, em 1924. Foi cônsul de Portugal na Noruega, de 1925 a 1930. Atuou também como jornalista e colaborador em várias publicações, entre as quais $A$ Ressurreição - que dirigiu e na qual trabalhou com Fernando Pessoa -, Presença, Seara Nova, Descobrimento, Gazeta Musical e Todas as Artes. Foi chefe de redação da revista cinematográfica Imagem. Pertenceu também ao grupo do Novo Cancioneiro, que revelava influências surrealistas, simbolistas e, sobretudo, neo-realistas. Sua obra reflete preocupação face aos problemas do mundo, "foi principalmente o porta-voz de um sentimento de remorso e responsabilização do intelectual por todas as brutalidades e injustiças" ${ }^{267}$. Lírios do monte, publicado em 1918, foi sua primeira obra poética e O mundo desabitado, publicado em 1960, sua primeira obra de ficção. Recebeu, em 1961, o $1^{\circ}$ Grande Prêmio de Poesia da Sociedade Portuguesa de Escritores e, em 1965, o Prêmio da Casa da Imprensa, pelo seu livro de reflexões e memórias $A$ memória das palavras. Embora tenha se destacado mais como poeta, Ferreira publicou romances, contos, crônicas, ensaios e memórias. Em 1958, com Carlos de Oliveira, coorganizou a antologia Contos tradicionais portugueses.

${ }^{266}$ FERREIRA, José Gomes. Aventuras de João Sem Medo: panfleto mágico em forma de romance. 17.ed., Lisboa, Publicações Dom Quixote, 1991.

267 SARAIVA, António José e LOPES, Oscar. História da literatura portuguesa. 17.ed., Porto, Ed. Porto, 1996, p. 1038. 
Em Aventuras de João-Sem-Medo, publicadas inicialmente em episódios na revista infantil O Senhor Doutor, no ano de 1933, Ferreira conta a estória de um rapaz que vivia na pequena aldeia de Chora-Que-Logo-Bebes, vizinha à Floresta Branca, "onde os homens, perdidos dos enigmas da infância, haviam instalado uma espécie de Parque de Reserva de Entes Fantásticos" ${ }^{268}$. Ninguém da povoação se atrevia a penetrar na floresta, não só por causa do altíssimo muro que fora construído em redor da mata, mas também porque os habitantes do vilarejo eram criaturas desanimadas, temerosas e tristes, que só viviam a se lamentar.

A única pessoa daquele lugar que tinha temperamento alegre e destemido era justamente o João, conhecido por todos como João Sem Medo. É ele quem vai desafiar a proibição expressa de entrar no Parque, em aviso afixado no muro: "É proibida a entrada a quem não andar espantado de existir" ${ }^{269}$. Para o desespero de sua mãe, o rapaz, com o auxílio de plantas trepadeiras, escala o alto obstáculo e inicia longa jornada floresta adentro, durante a qual irá deparar-se com os seres mais fantásticos e enfrentar as situações mais inusitadas.

Narradas em ritmo vertiginoso, em que as ações se sucedem rapidamente, sem dar tempo de reflexão ao leitor, as aventuras vividas por João Sem Medo estão repletas de seres vegetais, minerais, animais, entre outros objetos antropomorfizados ou simplesmente biotecnológicos, como bichos mecânicos e automóveis com braços. Há, por exemplo, homem sem cabeça; seixos com dentes, que mordem os pés do rapaz; árvores de dez braços, que o arremessam umas para as outras em jogos malabares; fadas verdadeiras e fadas falsificadas; princesas; gramofones com asas; seres humanos que têm lâminas de faca no lugar dos dedos; seres cujo corpo é uma caixa de ressonância apoiada em pernas de papagaio e cuja cabeça tem a forma de toca-disco; príncipe com orelhas de burro; homens máquinas; homens que vivem em árvores e se comunicam como as aves; ídolos e gigantes monstruosos; personagens de fábulas famosas; menina de pés ocos, entre outros. Enfim, a galeria de tipos é bastante extensa. Dada as características de determinadas personagens, pode-se inferir que José Gomes Ferreira tenha sido de

\footnotetext{
${ }^{268}$ FERREIRA, José Gomes. Aventuras de João Sem Medo: panfleto mágico em forma de romance. Lisboa, Publicações Dom Quixote, 1991, p. 11.

${ }^{269}$ Idem, ibidem, p. 13.
} 
alguma forma influenciado pelo Manifesto Futurista, do poeta italiano Filippo Tommaso Marineti ${ }^{270}$.

Além de estranhas criaturas, também os lugares e os ambientes descritos são os mais inusitados possíveis: lagos elásticos que aumentam quando João, a nado, tenta atingir a margem; pomares em que as frutas se transformam sucessivamente em cabeças de bonecas, bolas de ouro, criam asas e voam; deserto a partir do qual todas as direções levam ao mesmo ponto; cidade onde tudo é ao contrário, onde os aviões andam debaixo da terra e os automóveis e trens voam; palácio sem portas nem janelas, no qual se entra, mas do qual não se sai; caverna com mais de um andar, vários salões, elevador e esteira rolante, são apenas alguns deles.

Todos esses seres e espaços fantásticos, evidentemente, só poderiam ensejar situações também fantásticas, como a transformação de João em árvore, em fumaça, em fonte de água; a fuga do rapaz do palácio da morte; o diálogo com a Lua, que responde ao pensamento por meio de cartazes; a Fada dos Sonhos, que mergulha dentro da boca de João; a boca etérea ambulante, que se materializa em todos os lugares e enuncia sempre o mesmo enigma; a desintegração no ar da personagem que é a versão medrosa de João Sem Medo; o desdobrar de João em dois, para que um volte a Chora-Que-Logo-Bebes e o outro viva no mundo da imaginação mágica, e muitas mais.

Sobre a criação da obra, diz Ferreira ${ }^{271}$, em nota final da segunda edição:

[...] decidi inventar um herói de sabor popular que desafiasse as forças enigmáticas da Floresta Branca (branca, cor convencional da infância), desmitificasse os Gigantes, os Príncipes, as Princesas, as Fadas, etc., me permitisse criar novos mitos, tornar mágicos os objectos vulgares da vida diária e dar contorno às minhas verdades mais profundas numa linguagem de acção poética que a muitos, até

${ }^{270} \mathrm{O}$ primeiro manifesto foi publicado no Le Fígaro de Paris, em 22/02/1909, e nele, o poeta italiano Filippo Tommaso Marinetti, dizendo que "o esplendor do mundo enriqueceu-se com uma nova beleza: a beleza da velocidade. Um automóvel de carreira é mais belo que a Vitória de Samotrácia". O segundo manifesto, de 1910, resultou do encontro do poeta com os pintores Carlo Carra, Russolo, Severini, Boccioni e Giacomo Balla. Os futuristas saúdam a era moderna, aderindo entusiasticamente à máquina. Para Balla, "é mais belo um ferro elétrico que uma escultura". Para os futuristas, os objetos não se esgotam no contorno aparente e seus aspectos se interpenetram continuamente a um só tempo, ou vários tempos num só espaço. O grupo pretendia fortalecer a sociedade italiana através de uma pregação patriótica que incluía a aceitação e exaltação da tecnologia. Fonte: FUTURISMO.

História da arte. http://www.historiadaarte.com.br/futurismo.html. Acesso em: 12 abr. 2008.

${ }^{271}$ Idem, ibidem, p. 200. 
a mim mesmo, só me parecia possível, quando dirigida a crianças imaginárias (que todos trazemos escondidas na nossa soberba gravidade de adultos).

A efabulação em Aventuras de João Sem Medo, afora o fato de entreter, dadas as passagens por si só divertidas, constitui capítulo a capítulo metáfora de situações sociais identificáveis para o leitor crítico. Pode-se, portanto, perceber referências à natureza já histórica e culturalmente reconhecida como um tanto quanto nostálgica do povo português; ao modo de organização institucional e política das sociedades ocidentais; às práticas de interação social padronizadas; à utilização de formas de pensamento clichês; ao preconceito contra indivíduos que questionam as normas vigentes, seja por meio de discurso ou de atitudes; à exploração do homem pelo homem; à resistência das pessoas com relação às mudanças, entre tantas outras. As várias possibilidades de leitura, aliás, já eram previstas pelo próprio autor ${ }^{272}$ :

[...] a ambiguidade excedia a trapalhada difusa habitual. Porque, além da mescla de romance popular e de panfleto mágico, muitos iriam considerá-lo uma sátira à casca de certos aspectos do ambiente pátrio, outros descobrir-lhe-iam talvez acentos menos restritos (como, por exemplo, a filosofia de que o Tédio, ou mais portuguesmente a Chatice impera, dominadora e total, na vida do século $X X$ do nosso planeta) e todos por fim embarcariam na confusão, até certo ponto legítima, desta história parecer exclusivamente destinada a crianças (que só lhe poderão entender a superfície).

Há de se lembrar que Aventuras de João Sem Medo veio a público pela primeira vez em 1.933 ano em que se instituía em Portugal o regime político denominado Estado Novo, sob a direção de António de Oliveira Salazar, que vigorou sem interrupções até 1.974. Semelhante em alguns aspectos aos regimes instituídos por Benito Mussolini, na Itália, e por Adolf Hitler, na Alemanha, o salazarismo, como ficou conhecido, diferia desses pela postura paternalista adotada por Salazar, que se

${ }^{272}$ Idem, ibidem, p. 209. 
expressava por meio de falas mansas e sem as poses bombásticas e militaristas de seus congêneres.

As principais características do Estado Novo português foram: ideologia católica; aversão ao liberalismo político; censura aos meios de comunicação; onipresença da PIDE, polícia política; projeto nacionalista e colonial; discurso e prática anticomunistas; economia controlada por cartéis constituídos à sombra do governo; forte tutela sobre o movimento sindical. Durante sua vigência, o Estado Novo sofrerá fortes abalos, impostos por movimentos políticos tanto de direita quanto de esquerda, mas acaba caindo vitimado por conspiração dirigida pelo Movimento das Forças Armadas, em 25 de abril de 1974.

Se, por um lado, durante o Estado Novo a população portuguesa adulta passou a conviver com a forte repressão e censura política às publicações periódicas e emissoras de rádio e televisão, por outro, os anos de 1930, que marcam o início do regime imposto por Salazar, são considerados época de ouro no campo da literatura para a infância e juventude naquele país. O reconhecimento da criança como consumidor de livros favoreceu também o surgimento de jornais, revistas e suplementos infantis, em que colaboraram muitos autores e artistas. Com relação ao conteúdo das obras publicadas no período, depois do teor mais pedagógico das primeiras décadas do século, "constata-se cada vez mais ficção e fantasia nos livros para a infância" 273 .

\subsection{Estudo comparativo}

O empreendimento de um estudo comparativo na área de Literatura para Crianças e Jovens atende a objetivos diversos, que podem voltar-se para a apreensão ora dos processos de construção de significados empregados pelos escritores e ilustradores das obras, ora dos conteúdos ideológicos veiculados por meio das mensagens, ora das práticas de leitura e uso educacionais que se fazem do objeto livro, entre outros.

Em Literatura Comparada, linha de pesquisa que se abre para a investigação de vários fenômenos do fazer literário, não há um determinado método a ser seguido, justamente pelas diferentes possibilidades de análise oferecidas. O que se

${ }^{273}$ BLOCKEEL, Francesca. Literatura juvenil portuguesa contemporânea: identidade e alteridade. Lisboa, Caminho, 2001, p. 43. 
tem, no entanto, são algumas premissas que não devem escapar à observação do pesquisador, para que, a partir da seleção de uma ou algumas delas, ele possa desenvolver seu trabalho.

Antes de tudo, deve-se compreender que, apesar de chamar-se comparatista, um estudo nessa área trata muito mais de relacionar literaturas do que propriamente comparar. Outro fato a ser levado em conta é a orientação fundamental que tem tido a literatura comparada para o conhecimento teórico da imagem do estrangeiro que se constrói no interior de um texto, ou seja, para análise do intercâmbio de influências entre diferentes culturas e nações. Se bem que, referentemente a esse aspecto, recentes tendências no setor apontam para uma ampliação do conceito de nacionalidade, baseadas no reconhecimento de que a literatura comparada caracteriza-se como um processo de investigação da literatura na sua totalidade, isto é, universal. Dizem Wellek e Warren ${ }^{274 .}$

[...] O grande argumento a favor da literatura "comparada" ou "geral", ou apenas "literatura", é a evidente falsidade da idéia de uma literatura nacional contida em si própria. A literatura ocidental, pelo menos, constitui uma unidade, um todo.

Entre os teóricos da literatura comparada, encontram-se Machado e Pageaux ${ }^{275}$, que apontam caminhos pelos quais um estudo comparativo pode seguir. Primeiramente, eles destacam a viagem como "tema literário", esclarecendo que este pode servir como elemento estruturante de um texto ou de reconhecimento do imaginário do autor. A seguir, reiteram a respeito do estudo da dimensão estrangeira em um determinado texto, em uma determinada literatura ou cultura, salientando que esse é um dos métodos mais antigos em literatura comparada. Os elementos constitutivos da imagem do estrangeiro em uma obra podem ser observados, segundo os autores, por meio de levantamento do léxico empregado no processo de referenciação do país; das relações hierárquicas presentes na estrutura sintagmática do texto e, ainda, da análise do quadro espácio-temporal descrito pelo autor. Um terceiro tipo de pesquisa é aquele a partir do qual se busca compreender

${ }^{274}$ WELLEK, René e WARREN, Austin. Teoria da literatura. 5.ed., Lisboa, Publicações EuropaAmérica, 1971, pp. 57-8.

${ }^{275}$ MACHADO, Álvaro e PAGEAUX, Daniel-Henri. Da literatura comparada à teoria da literatura. Lisboa, Edições 70, s/d. 
o percurso percorrido da influência à recepção de determinada obra. Nesse caso, pergunta-se a respeito das razões e das circunstâncias que corroboraram para que determinado texto fosse lido e interpretado de certa maneira. Por fim, falam Machado e Pageaux ${ }^{276}$ sobre aquilo que denominam "poética comparada", que se refere a uma espécie temática de estudo.

[...] O domínio agora abordado obriga o investigador a dirigir alternativamente a sua reflexão, ora para o texto literário como sistema, ora para o período cultural em que o texto foi produzido, de maneira a compreender mais globalmente, não o funcionamento dum determinado elemento do texto, mas sim toda a sua função, isto é, a função dum texto portador dum elemento ou conjunto de elementos textuais (tema / temática) que pode apresentar-se sob uma dupla forma: tema e motivo.

A diferença entre tema e motivo está relacionada com a estrutura do texto literário. Emprega-se o termo tema para referir-se àquilo que auxilia na estruturação do texto. Já por motivo entendem-se os elementos que não intervêm no plano dos princípios organizadores do texto, isto é, que não têm função estruturante.

Desenvolve-se no presente trabalho essa última modalidade de estudo, ou seja, analise-se de que forma um mesmo tema - o mito do herói - organiza a estrutura narrativa de O relógio de mundo, de Lino de Albergaria, e de Aventuras de João Sem Medo: panfleto mágico em forma de romance, de José Gomes Ferreira.

\subsubsection{Mito e literatura}

De acordo com Machado e Pageaux ${ }^{277}$, deverá "chamar-se tema a tudo aquilo que é elemento constitutivo e explicativo do texto literário, elemento que ordena e permite produzir o texto. Assim, o mito é um tema que tem um valor muito especial". Explicam também os autores que a maior parte dos estudos de temas leva em consideração a existência insofismável de temáticas universais, mas que eles (Machado e Pageaux) preferem falar não de temas universais, e sim de elementos

\footnotetext{
${ }^{276}$ Idem, ibidem, p. 115.

${ }^{277}$ Idem, ibidem, p. 116.
} 
recorrentes, reinvestidos simbolicamente de diferentes maneiras, segundo o espaço cultural e o momento histórico analisado ${ }^{278}$.

A raciocinar junto com os teóricos, se o mito é um tema e se este pode ser compreendido como elemento recorrente, reinvestido simbolicamente de diferentes maneiras, segundo o espaço cultural e o momento histórico analisado, pode-se descrever a maneira como o mito do herói está presente na base estrutural das narrativas de O relógio do mundo e de Aventuras de João Sem Medo. Mas esse procedimento por si só não estaria de acordo com o que preconiza as teorias mais atuais relativas ao campo da literatura comparada. Ainda segundo Machado e Pageaux, melhor será empreender, entre outros tipos, uma análise da história das idéias, especialmente quando o tema se aproxima ou se confunde com uma espécie de imagem. A palavra imagem aqui é compreendida não só como designando um conjunto de idéias sobre o estrangeiro num processo de literarização, mas também como a representação literária de um espaço específico ou de um contexto sóciohistórico e cultural, verificada em uma determinada obra. Dizem os autores ${ }^{279}$ :

[...] o estudo do tema [...] obriga o investigador a empreender duas leituras simultâneas dos textos analisados: em primeiro lugar, o texto é, no plano da criação literária, um universo coerente; em segundo lugar, a procura dum sentido deve ser feita no interior do texto e também no conjunto do campo cultural a que esse texto pertence. Assim passa-se obrigatoriamente duma análise formalista ou estruturalista do texto para uma análise intertextual e cultural: o texto literário é o lugar dialéctico onde se articulam estruturas textuais e extra-textuais, participando do tema, justamente das duas séries. O estudo temático revela, afinal, claramente, as duas fases indissociáveis da investigação literária: o estudo do funcionamento interno dum texto (dum tema num texto, a leitura contribuindo para pôr em evidência, para reconstituir um conjunto de funções) e o estudo da função social e cultural desse mesmo texto.

Dessa forma, por meio da análise comparativa das obras de Albergaria e Ferreira, busca-se, além de descrever a estrutura temática dos textos, compreender

\footnotetext{
${ }^{278}$ Idem, ibidem, p. 117.

${ }^{279}$ Idem, ibidem, p. 117.
} 
também os símbolos empregados por cada autor no revestimento do mito do herói, de acordo com elementos próprios da cultura do país de que são originários. Em assim o fazendo, torna-se possível conjeturar a respeito do tipo de representação literária, isto é, da imagem metafórica que os autores constroem do espaço-tempo histórico da nação em que vivem.

Para tanto, cumpre como condição fundamental buscar, primeiramente, uma definição de mito. Nesse sentido, pode-se contar com o auxílio de Eliade ${ }^{280}$ :

[...] o mito conta uma história sagrada; ele relata um acontecimento ocorrido no tempo primordial, o tempo fabuloso do "princípio". Em outros termos, o mito narra como, graças às façanhas dos Entes Sobrenaturais, uma realidade passou a existir, seja uma realidade total, o Cosmo, ou apenas um fragmento: uma ilha, uma espécie vegetal, um comportamento humano ${ }^{281}$, uma instituição. É sempre, portanto, a narrativa de uma "criação": ele relata de que modo algo foi produzido e começou a ser. [...] a principal função do mito consiste em revelar os modelos exemplares de todos os ritos e atividades humanas.

O conceito acima vai ao encontro do que é apresentado por Machado e Pageaux ${ }^{282}$. Segundo eles:

[...] mito é uma narrativa que dá sentido ao universo. A formação de um mito coincide com a constituição de um grupo em sociedade que pretende tornar o mundo inteligível e organizado, dando um sentido às relações interindividuais.

Em segundo lugar, é necessário refletir a respeito da relação entre mito e literatura e sobre o papel do escritor nesse contexto. Sabe-se que o mito pode tornar-se elemento primordial da organização de um texto literário; o fator inspirador da produção textual. Cabe, conseqüentemente, buscar conhecer o que confere ao

\footnotetext{
${ }^{280}$ ELIADE, Mircea. Mito e realidade. Trad. Pola Civelli. São Paulo, Perspectiva, 2002, pp. 11-3.

${ }^{281}$ Grifo nosso.

${ }^{282}$ MACHADO, Álvaro e PAGEAUX, Daniel-Henri. Da literatura comparada à teoria da literatura. Lisboa, Edições 70, s/d., p. 126.
} 
mito, no plano da literatura, essa capacidade de criação e, no plano ético, uma função de exemplaridade.

No que concerne às definições apresentadas, apreende-se o mito apenas como algo originário de uma dimensão coletiva, ao passo que na literatura o mito é uma estória contada por um determinado autor, que tem no mito inaugural a referência de uma história coletiva, a partir da qual ele cria uma estrutura narrativa com feições pessoais. Em outras palavras, o escritor baseia-se na efabulação primordial de uma coletividade, introduzindo aí modificações que irão caracterizar-se como geradoras de uma variante do mito, ao mesmo tempo em que darão pistas da sua contribuição pessoal à narrativa tradicional. Ainda sobre esse assunto, vale ressaltar o que pensam Machado e Pageaux ${ }^{283}$ :

No plano estritamente literário, o mito é uma linguagem secundária. Podemos mesmo dizer duplamente secundária: é secundária pelo facto de o escritor dele "extrair" uma história em que penetrará e que desenvolverá; é secundária porque o escritor vai também, mais ou menos, fundir-se com essa história, investir nela, dado que ela constitui um elemento de explicação íntima, pessoal. É uma linguagem secundária ou, se preferirmos, simbólica: por um lado, há realidade mítica, feita precisamente de um certo número de elementos obrigatórios sem os quais não haveria mito, história mítica; por outro lado, há variantes pessoais, susceptíveis de dar, pelas opções, pela lógica interna do escritor, novos significados ao mito na sua versão corrente.

Direcionando-se agora a reflexão para função ética do mito, cuja característica é a exemplaridade para as ações humanas, nota-se que o mito do herói revela o modelo exemplar do rito de iniciação, que simboliza na vida social a passagem do jovem para a idade adulta. Relata Propp ${ }^{284}$ :

[A iniciação é] uma instituição própria do regime tribal. Esse rito ocorria no momento da puberdade. Ao cumpri-lo, o jovem era introduzido na sociedade tribal, da qual se tornava membro investido

\footnotetext{
283 Idem, ibidem, p. 130.

${ }^{284}$ PROPP, Vladimir. As raízes históricas do conto maravilhoso. Trad. Rosemary Costhek Abílio e Paulo Bezerra. São Paulo, Martins Fontes, 2002, p. 54.
} 
de plenos direitos, ao mesmo tempo em que adquiria o direito de se casar.

A compreensão de que o mito do herói reveste o rito de passagem é compartilhada por Campbell ${ }^{285}$ :

[...] a estrutura e algo do sentido espiritual dessa aventura já podem ser detectados na puberdade ou nos rituais de iniciação das primitivas sociedades tribais, por meio dos quais uma criança é compelida a desistir da sua infância e a se tornar um adulto.

No percurso do herói são verificadas necessariamente as etapas: partida, realização e retorno. O processo inicia-se quando o indivíduo sente que lhe está faltando ou sendo negado algo de que se julga merecedor. Esse ser então parte rumo ao desconhecido, numa série de aventuras inusitadas, em busca daquilo que venha preencher essa necessidade, isto é, de encontrar o que lhe falta. Uma vez atingidos os objetivos, dá-se a volta e a transformação da situação anteriormente estabelecida.

$\mathrm{Na}$ literatura, o gênero que mais tradicionalmente se tem estruturado de forma simbólica com base no mito do herói e que, por conseqüência, aborda a transição da adolescência para a maturidade é o conto maravilhoso. Como se sabe, os significados simbólicos dos contos maravilhosos relacionam-se com os problemas existenciais que o homem enfrenta ao longo do processo de desenvolvimento mental e emocional. Para explicar o conto maravilhoso, ninguém melhor do que Coelho ${ }^{286}$ :

No início dos tempos, o maravilhoso foi a fonte misteriosa e privilegiada de onde nasceu a literatura. Desse maravilhoso nasceram personagens que possuem poderes sobrenaturais; deslocam-se, contrariando a leis da gravidade; sofrem metamorfoses contínuas; defrontam-se com as forças do Bem e do Mal, personificadas; sofrem profecias que se cumprem; são

${ }^{285}$ CAMPBEL, Joseph e MOYERS, Bill. O poder do mito. Org. Betty Sue Flowers. Trad. Carlos Felipe Moisés. Palas Athena, 1990, p. 132.

${ }^{286}$ COELHO, Nelly Novaes. Literatura infantil: teoria, análise, didática. São Paulo, Moderna, 2000, p. 172. 
beneficiadas com milagres; assistem a fenômenos que desafiam as leis da lógica, etc.

No conto maravilhoso produzem-se acontecimentos que não podem ser explicados pelas leis do mundo familiar, mas não provocam qualquer reação particular de dúvida ou estranheza nem nas personagens nem no leitor implícito da narrativa, uma vez que esses aceitam as regras do "jogo" assim como lhes são propostas pelo narrador, diferentemente do que ocorre nos gêneros do fantástico e do estranho. "Não é uma atitude para com os acontecimentos contados que caracteriza o maravilhoso, mas a própria natureza desses acontecimentos", diz Todorov ${ }^{287}$.

Diante do exposto, é perfeitamente justificada a classificação das obras $O$ relógio do mundo e Aventuras de João Sem Medo como pertencentes ao gênero do conto maravilhoso. Mas para que essa categorização seja mais bem fundamentada, é importante demonstrar também de que maneira as narrativas estruturam-se com base no mito do herói na sua função exemplar de rito de passagem.

\subsubsection{Invariantes do conto maravilhoso}

Com base em Propp ${ }^{288}$, os contos maravilhosos apresentam estrutura similar constante, no interior da qual são encontradas funções invariantes e variantes. A partir do modelo estrutural do pesquisador russo, Coelho ${ }^{289}$ extrai cinco invariantes - aspiração (ou desígnio), viagem, obstáculos (ou desafios), mediação auxiliar e conquista do objetivo (final feliz). São essas as invariantes presentes nos textos em estudo aqui demonstradas, esclarecendo-se que, com relação às variantes, objetivou-se analisar de modo aprofundado apenas a obra de Albergaria (Cap.3).

Primeira invariante: uma aspiração ou um desígnio leva o herói à ação.

${ }^{287}$ TODOROV, Tzvetan. As estruturas narrativas. Trad. Leyla Perrone-Moisés. 4.ed., São Paulo, Perspectiva, 2004, p. 160.

${ }^{288}$ PROPP, Vladimir. Morfologia do conto. Trad. Jaime Ferreira e Vítor Oliveira. Lisboa, Vega, 1978.

${ }^{289}$ COELHO, Nelly Novaes. Literatura infantil: teoria, análise, didática. São Paulo, Moderna, 2000, pp. 109-10. 
Em O relógio do mundo, Casemiro Correia é obrigado por seu pai, o Capitão Cornélio Correia, a abandonar Cravo Branco e a enfrentar as forças desconhecidas de Cucura e da floresta, que lutavam contra a ambição dos predadores. A cidade encantada e a preservação da natureza são representadas, na obra, pela borboleta de asas prateadas e pela coruja. A borboleta só era percebida por Camélia Correia, a mãe de Casemiro. A ave, por sua vez, era compreendida pelos homens comuns como presságio de mau agouro.

- Siga esse bicho aonde for, mas acabe com sua vida agourenta! — trovejava o Capitão. ${ }^{290}$

Em parte, há a obrigação, o desígnio, como elemento motivador da personagem, mas a aspiração, a necessidade de vivenciar novas experiências, também é notada, na seguinte frase do narrador:

Era a oportunidade de virar as costas à decadência e às dificuldades de Cravo Branco. ${ }^{291}$

Na obra de José Gomes Ferreira, é unicamente a aspiração que move o herói, inconformado com a natureza melancólica e queixosa dos habitantes da aldeia Chora-Que-Logo-Bebes, onde vivia. É o que se nota no seguinte trecho:

O único que, talvez por capricho de contradizer o ambiente e instinto de refilar, resistia a esta choradeira pegada, era o nosso João que, em virtude duma contínua ostentação de bravata alegre e teimosa na luta, todos conheciam por João Sem Medo.

Ora um dia, farto de tanta chorinquice e de tanta miséria que gelava as casas e cobria os homens de verdete, disse à mãe que, conforme a tradição local, lacrimejava no seu canto de viúva:

- Mãe: não aturo mais isto. Vou saltar o Muro [que cercava a floresta]. ${ }^{292}$

\footnotetext{
${ }^{290}$ O relógio do mundo, p. 11.

291 Ibidem, p. 11.

292 João Sem Medo, p. 12.
} 
Segunda invariante: o herói parte em viagem, rumo ao desconhecido.

Compare-se o momento da partida nas duas narrativas em estudo. Primeiramente, a personagem criada por Albergaria:

[...] Casemiro foi saindo arrastando a arma. Na varanda, se despediu dos pais e tomou o final da rua para passar à floresta.

- Adeus, meu Capitão! Adeus, minha Capitã!

Os velhos acenaram para o filho caçula. Camélia passou a manga da blusa no cantinho do olho.

Amarelinho [apelido de Casemiro] teve de se abaixar para passar debaixo dos cipós, que quase se arrastavam pela terra. ${ }^{293}$.

A seguir, o herói inventado pelo escritor português:

[...] as implorações da mãe não impediram que, na manhã seguinte, João Sem Medo se esgueirasse de Chora-Que-LogoBebes e se dirigisse à socapa para o tal Muro que cercava a floresta [...] Graças ao arrimo de uma trepadeira providencial e auxiliado pelas sentinelas invisíveis que guardavam aquela selva misteriosa $\mathrm{e}$ pretendiam facilitar-lhe a entrada, não sei com que intuitos secretos, chegou com agilidade ao topo da muralha. [...] Outra trepadeira miraculosa e pronto: João Sem Medo desceu a pulso, com os pés a apoiarem-se aqui e acolá nas junturas das pedras esverdeadas de musgo escorregadio. E assim conseguiu alcançar o solo da floresta [...]. ${ }^{294}$

Note-se que ambos partem para floresta. Ao tratar das raízes históricas do conto maravilhoso, Propp ${ }^{295}$ esclarece que esse gênero de narrativa surge das antigas religiões, em que era comum aos jovens passar pelo rito de passagem, cujas origens e funções já foram mencionadas. A floresta era justamente o lugar onde as

${ }^{293}$ O relógio do mundo, p. 12.

294 João Sem Medo, pp. 12-3.

${ }^{295}$ PROPP, Vladimir. As raízes históricas do conto maravilhoso. Trad. Rosemary Costhek Abílio e Paulo Bezerra. São Paulo, Martins Fontes, 2002, p. 9. 
sociedades primitivas celebravam esse ritual. Acreditava-se que, durante o rito, 0 adolescente morria e ressuscitava como um novo homem. Essa talvez seja a razão pela qual, no conto maravilhoso, a floresta tenha um significado ritualístico e simbólico. Trata-se do lugar onde o herói passa por experiências perturbadoras, provas difíceis e essenciais para seu desenvolvimento psicológico. Ainda de acordo com Propp ${ }^{296}$, a floresta "desempenha grosso modo um papel de obstáculo. A floresta em que se encontra o herói é impenetrável. É uma espécie de rede que prende o intruso". São justamente os obstáculos que se caracterizam como mais uma invariante na estrutura desse gênero narrativo.

Terceira invariante: obstáculos aparentemente intransponíveis opõem-se à ação do herói.

É nesta, e também na próxima etapa, que reside a maior parte da efabulação em ambas as obras; em que se encontram os mais variados motivos que corroboram para a construção dos sentidos e dão colorido peculiar às narrativas; em que cada escritor encontra maior espaço de mobilização do seu fazer criativo e apresenta seu contributo ao mito do herói, podendo-se falar até mesmo que manifesta seu mito pessoal. Tanto Casemiro Correia quanto João Sem Medo enfrentam uma série de obstáculos no interior da floresta. Citam-se algumas dessas dificuldades de um e outro herói, lembrando-se que, referentemente ao texto de Albergaria, descrições pormenorizadas já foram apresentadas (Cap. 3).

Em O relógio do mundo, antes mesmo de iniciar viagem, Casemiro Correia, sem perceber, já havia encolhido de tamanho. Ao entrar na floresta, fica menor ainda e até pequenos insetos, como a formiga, parecem-lhe bem maiores. Uma vez no interior da mata, o rapaz terá de escolher entre três caminhos diferentes. Seguirá aquele no qual ouve o pio da coruja. No entanto, não demora a se perder; a enfrentar forte chuva, que se transforma em enxurrada, leva embora sua espingarda e o carrega para a correnteza violenta do leito de um rio. No próximo instante, Casemiro sente-se tragado para dentro de um buraco muito fundo, até ver-se, depois de longa queda, no interior de uma caverna cujas paredes são de ouro. Nesse local, irá conhecer quatro índios com poderes sobrenaturais, que lhe dão de

${ }^{296}$ Idem, ibidem, p. 56. 
comer e beber, e lhe ensinam que ali o ferro "amadurece" em ouro, para que o mundo possa continuar girando em volta do Sol. Além disso, ainda no interior da caverna, o jovem, olhando para fogo, terá uma visão da coruja e de Cucura, a cidade encantada. Só depois disso é que será devolvido para a floresta, do outro lado da margem do rio.

Apesar de forte, a experiência ainda não havia servido para que Casemiro abandonasse o objetivo inicial imposto pelo pai, que era o de matar a coruja. Além disso, o rapaz alimentava a esperança de poder apoderar-se do ouro da caverna. Para que tenha a consciência ampliada, ele terá de enfrentar novos desafios, como o que ocorre quando consegue prender a ave, usando a própria camisa tal qual uma rede. Nesse momento, a natureza inteira reage de maneira sombria, como descreve o narrador:

Foi quando veio o frio. Casemiro se sentiu gelando. $O$ frio veio junto com o escuro. A árvore onde ele estava no mesmo instante secou. Perto, todas as árvores perdiam as folhas. O frio e a escuridão chamaram o silêncio. Todos os bichos interromperam seus ruídos. $\mathrm{E}$ também o rio se calou, sufocado pelo gelo. A escuridão e o frio se espalhavam em volta, mais intensos. Casemiro sentiu suas mãos endurecendo, parecia que iam virar pedra. ${ }^{297}$

$\mathrm{Na}$ seqüência, aparece o Caipora, defensor da mata, que julga o rapaz e manifesta intenção de puni-lo. A coruja, entretanto, intercede a favor de Casemiro, fato esse cujo desdobramento é demonstrado na invariante seguinte, como será visto. Não faltarão ainda obstáculos para que o rapaz atinja seu verdadeiro propósito, que não era, na verdade, o de capturar a ave e sim o de conhecer Cucura. Haveria ainda escuridão, ventania e um muro de pedras a serem enfrentados, até adquirir consciência dos elementos responsáveis pelo equilíbrio da natureza, tornar-se homem e estar em condições de entrevistar-se com o rei e a rainha da cidade encantada.

Por processo similar, isto é, de enfrentamentos de obstáculos passa o herói do panfleto mágico português. A diferença é que, talvez por trata-se de texto mais longo ou mesmo por ter sido publicado inicialmente em episódios, a quantidade de

${ }^{297}$ O relógio do mundo, p. 29. 
situações difíceis pelas quais passa João Sem Medo é significativamente maior. Algumas delas já foram descritas anteriormente, como o envolvimento de João com seres sobrenaturais que impedem seu retorno para casa. Vale, no entanto, destacar quatro passagens, ainda que de forma não pormenorizada.

A primeira refere-se a quando o rapaz é levado à Colina de Cristal, onde fica o palácio da morte. No interior da construção, que não tinha portas nem janelas, havia uma sala cujas paredes eram de platina e o chão de cristal. Nesse aposento, João encontra a foice e o cavalo da morte, que, num "salto prodigioso", rompe o telhado, libertando o rapaz. A segunda faz aludir à varinha de condão com a qual João pode obter o que quiser, com a condição de dar uma parte de seu corpo em troca. Não é à-toa que o capítulo relativo a essa passagem chama-se "O condão do sacrifício". Com o bastão, João vai transformar-se em fonte de água. Até ser socorrido por decisão tomada em uma assembléia de fadas, que dá ensejo à terceira passagem aqui destacada: João vê-se trancado na "sala sem portas" junto com a Fada do Sonho e com o direito de realizar qualquer sonho, mas cada sonho só pode durar cinco minutos. Ele apenas livra-se daquela sala quando engole a fada. A quarta passagem é o encontro de João Sem Medo com João Medroso, espécie de réplica física do herói, mas de caráter psicológico antagônico. Ambos ficam presos numa imensa caverna, repleta de inventos tecnológicos. É aí que o protagonista enfrenta um gigante poderoso, que o faz confrontar-se com suas próprias inseguranças, numa espécie de provação.

Uma vez tendo anotado algumas das dificuldades dos heróis das duas narrativas, cabe inserir, agora, comentário a respeito de um elemento que funciona no conto maravilhoso tanto como obstáculo, como mediação auxiliar. Trata-se da isbá, espécie de cabana com a qual o herói se depara em sua caminhada. Propp ${ }^{298}$ descreve essa habitação como "uma pequena isbá sobre patas de galinha", onde vive Baba Yaga, personagem que, na tradição dos contos russos, representa a forma clássica do doador de recurso mágico que irá auxiliar o herói a enfrentar os obstáculos. Às vezes, além de um objeto de poder, o herói recebe também alimentos nesse local.

Entendendo a isbá e o doador como funções invariantes do conto maravilhoso e sabendo que essas podem apresentar-se de maneira variada, compreende-se que

${ }^{298}$ PROPP, Vladimir. As raízes históricas do conto maravilhoso. Trad. Rosemary Costhek Abílio e Paulo Bezerra. São Paulo, Martins Fontes, 2002, p. 57. 
a gruta de ouro, onde cai Casemiro Correa, a Colina de Cristal e a sala sem portas, onde João Sem Medo permanece momentaneamente fechado, constituem representações da cabana à qual se refere Propp. É no interior desses recintos que as personagens vivenciam provações ao mesmo tempo em que recebem alguma forma de ajuda, ou seja, tanto enfrentam obstáculos quanto se beneficiam de mediação auxiliar, que se caracteriza na próxima invariante.

Quarta invariante: surge um auxiliar mágico, natural ou sobrenatural, que ajuda o herói a vencer.

Dentro da caverna, Casemiro Correia assusta-se com o fato de um índio conseguir ler seus pensamentos, o que já se configura numa provação. O rapaz havia imaginado o quanto seria bom levar um pouco do ouro daquela gruta para casa. Os outros índios, no entanto, oferecem-lhe comida e bebida. Além disso, fazem-no ter uma visão ao olhar fixamente para uma fogueira. No meio das chamas surge a imagem da coruja, a mesma que ele fora incumbido de matar.

— Olha bem dentro dos olhos da coruja - Capi dizia.

A coruja olhava Casemiro. Casemiro olhou nos olhos dela. Eles refletiam uma cidade dividida em duas, cada metade dentro de um olho. 299

Apesar de perceber tratar-se de Cucura, Casemiro, inicialmente, não compreende qual papel a ave irá desempenhar no seu caminho. É a coruja quem irá defendê-lo no julgamento do Caipora e o guiará até a entrada da cidade encantada.

Em Aventuras de João Sem Medo, a representação da isbá ocorre mais de uma vez, como já foi dito. Conseqüentemente, o surgimento de mediadores auxiliares também é recorrente. Na Colina de Cristal, João apodera-se do cavalo e da foice da morte, com os quais consegue retornar à vida. Em meio ao deserto, o rapaz recebe uma varinha de condão do presidente do Sindicato Internacional das Fadas e Artes Negras Correlativas. Dentro da sala sem portas, vê-se a Fada do Sonho ir morar no interior de João, o que lhe confere certa capacidade especial.

${ }^{299}$ O relógio do mundo, pp. 22-3. 
São esses os elementos mágicos de um e de outro texto que irão favorecer as personagens na busca de seus objetivos. O alcance desses configura-se a quinta invariante.

Quinta invariante: finalmente o herói conquista o almejado objetivo.

Em O relógio do mundo, Casemiro Correia atinge Cucura, entrevista-se com o rei Caruani e a rainha Coaraci e conhece o significado de seu nome. Na cidade mágica, compreende ainda a importância do ouro subterrâneo para o equilíbrio da natureza e da vida. Ao partir de lá, é homem feito, que sonha chegar logo à cidade natal. Uma vez em Cravo Branco, assume o lugar que era de seu pai, casa-se com Cordélia Camarão. A garota, antes magra e pálida, torna-se formosa e bela, a partir do restabelecimento da harmonia entre as duas cidades, o que ocorre, aliás, com todos os seres.

Cravo Branco tem suas casas velhas recuperadas do mofo e bem conservadas, brilhando ao sol. Ao norte, aos poucos, vai começando a mata, que não sufoca mais a cidade. ${ }^{300}$

Casemiro torna-se o Capitão, Cordélia, a Capitã. Os dois têm 12 filhos. O caçula, Calisto Correia, gosta de cuidar dos jardins, como o pai.

Já o objetivo de João Sem Medo, ao voltar para Chora-Que-Logo-Bebes, é organizar uma conspiração contra as lágrimas. Ele faz campanha para que as pessoas se alegrem, mas a população não o acata. Mesmo assim, o rapaz não perde as esperanças. Acha que tudo é apenas uma questão de tempo. Para esperar, monta uma fábrica de lenços, e enriquece.

\subsubsection{A exemplaridade do mito}

Como foi visto, dois autores de países de Língua Portuguesa - Brasil e Portugal —, em épocas diferentes - 1989 e 1933 —, utilizam o mito do herói como base de construção de seus textos, incorporando-o à realidade folclórica, sócio-

${ }^{300}$ Ibidem, p. 59. 
histórica e cultural de cada país. No que se refere ao papel do escritor nessa relação mito versus literatura, Machado e Pageaux ${ }^{301}$ explicam o que segue:

[...] o escritor encontra-se perante o mito numa situação de dependência, ele vai inserir-se, voluntariamente, note-se, numa tradição mítica; mas noutro plano, o escritor é tentado, por vezes obrigado, a modificar esse fundo mítico, dando-se uma feição pessoal, apropriando-se assim da história colectiva. Esta torna-se, portanto, para o escritor, de certo modo, chave explicativa, recurso primeiro e último, e as modificações que o escritor fará no cenário tradicional ou inicial serão decisivas para compreender quer a própria tradição (no estudo comparado de diversas variantes), quer o contributo pessoal do escritor, o que leva alguns a falar de "mito pessoal".

O contributo de Albergaria e de Ferreira, por meio das obras aqui destacadas, pode ser mais bem compreendido ao se levar em consideração a função de exemplaridade de mito. Tanto em O relógio do mundo quanto em Aventuras de João Sem Medo, o comportamento dos heróis é apresentado como uma espécie de exemplo a ser seguido, para que se alcance melhor qualidade de vida.

Assim, o rito de passagem é utilizado por Albergaria, no Brasil, no momento em que havia entre a população um movimento político de retorno à estabilidade democrática. $\mathrm{O}$ ano de publicação de $\mathrm{O}$ relógio do mundo coincide com o último do mandato de José Sarney, em que ocorriam no País as primeiras eleições diretas para presidente. Os tempos eram de expectativas favoráveis e de otimismo, com relação ao desenvolvimento das instituições e à ampliação da consciência de cidadania da população. Que as esperanças tenham vindo a se concretizar ou não, isso já é uma discussão que não cabe ser levantada neste trabalho. Importa, no entanto, suscitar a respeito da hipótese de que esse sentimento coletivo tenha sido representado na obra, notadamente no que se refere mais especificamente ao processo de conscientização sobre a necessidade de se preservar o meio ambiente.

Já em Portugal, o rito de iniciação é empregado por Ferreira metaforicamente de maneira a satirizar o modo como as instituições sociais estavam constituídas no

301 MACHADO, Álvaro e PAGEAUX, Daniel-Henri. Da literatura comparada à teoria da literatura. Lisboa, Edições 70, s/d., p. 129. 
momento em que se decretava no país o chamado Estado Novo. A referência ao estado de ânimo, ou melhor, de desânimo da população é explícita já no nome da cidade onde vive o herói: Chora-Que-Logo-Bebes. O nome da personagem - João Sem Medo - alude à função de exemplaridade do mito. Não é difícil imaginar que a população, vivendo sob um regime autoritário, como foi o de António de Oliveira Salazar, apresentasse comportamento temeroso e mesmo lamentoso. Mesmo que João não tenha conseguido transformar esse sentimento coletivo, sua forma de atuação aponta para uma proposta de se buscar extrair o melhor da situação.

Conforme se pode notar, a relação entre mito e literatura é fonte inesgotável de inspiração para escritores, que, ao criarem variantes de temas universais, acabam prestando inestimável contribuição a esses temas. 


\section{Conclusão}

A passagem da adolescência para a idade adulta é alvo de constante interesse por parte de pesquisadores nas áreas de Antropologia, Sociologia, Psicologia, Educação, Mitologia, entre outras. Em Literatura, desde os registros mais arcaicos, o tema tem sido fartamente explorado. Das narrativas míticas às realistas, passando pelos gêneros do fantástico e do maravilhoso, as dificuldades enfrentadas pelos jovens no limiar do "adultescer" estão presentes, tanto de modo referencial quanto simbólico, em contos de tradição oral, em textos recolhidos por grandes nomes da literatura universal, na obra de escritores internacionalmente consagrados, nos livros de autores contemporâneos. Também no cinema e nas histórias em quadrinhos, roteiristas de todas as épocas, e ainda na atualidade, não raramente baseiam-se nos conflitos característicos dessa faixa etária para a construção de seus enredos. Mais recentemente, a televisão e até os meios digitais abordam a problemática em suas produções voltadas para públicos de todas as idades. Além disso, o assunto tem rendido a redação de reportagens, artigos e comentários, amplamente divulgados por veículos especializados em Educação ou mesmo pela grande imprensa. Levando em consideração que os padrões de comportamento e relacionamento humano evoluem constantemente, o que explicaria a imemorial retomada dessa discussão, a qual, pelo que parece, está longe de se esgotar?

A impossibilidade de encontrar uma resposta categórica a essa pergunta fez com que, na realização do presente trabalho, se optasse por uma abordagem do assunto intermediada pela obra de um único autor de literatura para crianças e jovens, cuja maioria dos livros publicados aproxima-se do gênero que se denomina, desde sua origem na tradição alemã, "romance de formação"302 - narrativa em que se acompanha o amadurecimento das personagens em sua luta para enfrentar as vicissitudes da vida, geralmente através de processo no qual pureza e ingenuidade são paulatinamente substituídas por ceticismo prudente. Buscou-se, dessa forma, estudar a representatividade dessa importante fase do desenvolvimento humano nos textos de Lino de Albergaria, inseridos no contexto cultural brasileiro entre o final do

302 O livro Os anos de aprendizado de Wilhelm Meister, de Johann Wolfgang von Goethe, publicado em duas partes entre os anos de 1795 e 1796, é considerado obra fundadora do gênero de romance formação. 
século XX e início do século XXI. Com isso, acredita-se estar contribuindo para a compreensão, sob determinado ponto de vista, do que significa "tornar-se adulto" no limiar do terceiro milênio, quando a rapidez dos avanços tecnológicos e a conseqüente difusão acelerada das informações obrigam os seres humanos a rever valores e hábitos, com o objetivo de adaptarem-se às mudanças sociais.

Nascido em 1950, Lino de Albergaria é simultaneamente observador e personagem desse período de profundas transformações comportamentais. Sua trajetória de vida e sua formação acadêmica e profissional contribuíram para que se tornasse narrador privilegiado de seu tempo. A partir da Belo Horizonte natal, divisou largas perspectivas do país onde vive. De Minas Gerais, herdou a tradição de grandes nomes da literatura brasileira. De Paris, na França, onde viveu e cursou Editoração, entre o final dos anos 1970 e início de 1980, trouxe visão ampliada de mundo, tão necessária a quem se dedica a falar para a juventude. De São Paulo, cidade na qual se iniciou como editor, assimilou o ritmo de produção industrial, que Ihe permitiu publicar diferentes coleções literárias, com textos de vários autores, sem nunca ter negligenciado seu talento de escritor. Do Rio de Janeiro, local em que morou por quase um ano, adquiriu algo da informalidade característica dos habitantes da antiga capital do Brasil. Na qualidade de Comunicador Social, iniciouse nas técnicas midiáticas de propagação de mensagens. No curso de Letras, desenvolveu conhecimentos técnico-teóricos sobre Língua Portuguesa e Literaturas, áreas em que atingiu os elevados graus de mestre e doutor. Em dezenas de livros para crianças e jovens ${ }^{303}$, o autor trata com acuidade e sensibilidade os conflitos típicos do crescimento humano. Escritos em linguagem ágil, ricos em recursos estilísticos e engendrados por meio de técnicas narrativas bem elaboradas, os enredos de Albergaria colocam em foco o esforço das personagens para melhor conhecerem si próprias e o mundo que as cerca, independentemente da faixa etária em que se encontram. É justamente essa característica que justifica a escolha de sua obra como objeto de investigação neste trabalho.

Como forma de abordagem do vasto corpus pesquisado, optou-se primeiramente por resenhar todos os textos do autor para crianças e jovens publicados até o fechamento desta tese (ver Apêndice), buscando explorar questões não só pertinentes ao conteúdo - com base em estudos de Psicologia - como

${ }^{303}$ Até o início de 2008, eram 65 livros para os públicos infantil e juvenil, todos resenhados no Apêndice desta tese. 
também relacionadas às potencialidades discursivas - à luz de fundamentos relativos às áreas de Teoria Literária, Literatura Comparada, Semiótica, Semiolingüística e Narratologia. Esse método permitiu selecionar de forma segura a obra que viria a se constituir em objeto de análise mais aprofundada: $O$ relógio do mundo ${ }^{304}$.

Ante a necessidade de subsídios teóricos para o estudo temático, objetivo primordial no presente trabalho, julgou-se por bem descrever o pensamento de alguns dos mais importantes psicólogos, independentemente de correntes teóricas preconizadas. Para além de eventuais divergências, o que se buscou, de fato, foi realçar os aspectos semelhantes encontrados. Sabia-se de antemão a respeito da clássica ruptura ocorrida, no início do século $\mathrm{XX}$, entre os estudiosos da psicologia do ego e os da psicologia do self, a primeira representada pela Psicanálise, de Sigmund Freud, e a segunda por Carl Gustav Jung, fundador da escola conhecida como Psicologia Analítica. No entanto, os estudos empreendidos confirmaram a hipótese previamente imaginada, ou seja, a de que psicologia do ego e psicologia do self devem ser compreendidas como complementares. Conforme observa Levinson ${ }^{305}$, os seguidores das teorias freudianas inclinam-se a olhar para a maturidade mais "como uma cena na qual os conflitos inconscientes da infância são reativados do que um período de desenvolvimento avançado." Ainda para o pesquisador $^{306}$, foi precisamente Jung quem, a partir das descobertas de Freud, avançou em direção ao estudo do desenvolvimento adulto. Seguindo o raciocínio de Levinson, concluímos que as teorias relacionadas à psicologia do self só foram possíveis a partir das descobertas relacionadas à psicologia do ego e que, portanto, na busca da compreensão do desenvolvimento humano, a melhor conduta é deixar de lado eventuais rixas e rupturas motivadas mais por interesses outros que não científicos.

Tendo em vista o exposto, organizou-se a construção desta tese em três segmentos. 1) Durante o trabalho de tratamento do corpus, que consistiu na leitura e elaboração de resenhas dos livros, foram utilizados os fundamentos teóricos da psicologia do ego e da educação, justamente pelo de grau de especificidade que apresentam com relação ao comportamento da infância e da adolescência.

\footnotetext{
${ }^{304}$ Ilustrações de Rogério Borges. 16a. ed., São Paulo, Atual, 2005, 64p.

305 LEVINSON, J. Daniel et al. The Seasons of a Man's Life. New York, Ballantine Books, 1978, p. 4.

${ }^{306}$ Idem, ibidem.
} 
Subsidiaram preferencialmente a abordagem das obras os pensamentos de: Jean Piaget, Melanie Klein, Peter Blos, Contardo Calligaris, Diana Lichtenstein Corso e Mario Corso. 2) Já referentemente ao estudo sobre a passagem da adolescência para a vida adulta, objetivo central do presente trabalho, empregou-se unicamente a psicologia do self, ou seja, aplicou-se com exclusividade a teoria da individuação de Jung ao percurso da personagem Casemiro Correia, no enredo do livro O relógio do mundo. 3) Em seguida, buscou-se comparar, em termos ideológicos, a compreensão sobre o processo do amadurecimento humano em épocas e locais diferentes. Nesse sentido, com o auxilio do que preconiza as teorias da Literatura Comparada, conforme as descrevem Álvaro Machado e Daniel-Henri Pageaux, aproximou-se o conteúdo do texto de Lino de Albergaria ao de Aventuras de João Sem Medo: panfleto mágico em forma de romance, clássico português de José Gomes Ferreira, publicado pela primeira vez em Lisboa, no ano de 1933.

Uma vez esclarecidos os princípios metodológicos que nortearam a realização deste trabalho, desenvolvem-se as conclusões relativas a cada etapa do processo.

\subsection{Maturidade segundo a psicologia do ego}

A respeito da primeira fase, com vistas especificamente à passagem para a idade adulta, as conclusões a que se chegam dizem respeito às características fisiológicas e psicológicas da adolescência. De modo geral, os estudiosos apontam a transformação corporal como fator demarcatório fundamental. As mudanças ocorridas no corpo - tamanho, peso, proporção, surgimento de pêlos - obrigam o jovem a elaborar um trabalho de adaptação, que consiste em aceitar compulsoriamente a perda da condição infantil e a projetar uma forma de identidade no mundo adulto. Coincide com essa fase a percepção da maturidade dos órgãos genitais. Todo esse processo é passível de crises existenciais, geradas pela necessidade que o adolescente tem de comparar o modo como ele se vê com o modo como os outros o percebem. Os desequilíbrios daí decorrentes podem revelarse tanto na recusa sistemática, consciente ou inconsciente, em renunciar aos cuidados oferecidos pelos pais ou responsáveis quanto na dificuldade de aceitar responsabilidades. 
Como mecanismos de defesa, o indivíduo tende a eleger ídolos com os quais possa se identificar ou a participar de grupos no interior dos quais padrões de comportamento pautem-se por referências bastantes claras. Outra forma de subterfúgio está relacionada com as manifestações de egocentrismo e narcisismo. Longe de serem compreendidas como negativas, essas formas de expressão são oriundas do esforço que o jovem faz para equilibrar pensamento formal e realidade. Em virtude da distância verificada entre reflexão e mundo circundante, a tendência do adolescente é tentar fazer com que a realidade se adapte a sua maneira de pensar e não o contrário. Decorre daí a necessidade dos indivíduos dessa faixa etária de empreenderem revoluções políticas e sociais.

O mesmo processo ocorre no campo da afetividade, em que se pode verificar certa assimetria entre sentimentos e relações com o próximo, resultando em amargas decepções. Tema recorrente no pensamento dos psicólogos estudados é o surgimento na adolescência do instinto para amar. Porém, todos concordam que os relacionamentos amorosos que se estabelecem nessa etapa da vida configuram-se como expedientes transitórios, utilizados pelo jovem para livrar-se da dependência que, em determinado grau, o mantém ligado emocionalmente à mãe ou ao pai. $\mathrm{O}$ sentido da paixão é, nesse caso, o da projeção dos próprios ideais em um ser amado. Atuando dessa maneira, o adolescente busca espelhar-se e reconhecer-se no outro, em uma tentativa de obter definição de identidade. Em várias situações, podem ocorrer relacionamentos fictícios, espécie de mecanismo fantasioso de eleger pessoas às quais se atribui qualidades, para que, por intermédios delas, seja possível liberar os próprios instintos. Além das atribulações inerentes à faixa etária, as dificuldades no campo afetivo-sexual teriam como causa, na visão dos especialistas, a moratória imposta aos adolescentes, pelo menos aos das classes mais favorecidas, no que se refere à assunção de determinadas responsabilidades antes de estarem acadêmica e profissionalmente bem encaminhados. Considerando-se que a preparação para o ingresso no mercado de trabalho demanda cada vez mais tempo, é de se imaginar as adversidades enfrentadas pelos jovens.

Em suma, a visão ampla dos especialistas é a de que o amadurecimento caracteriza-se por ser um processo longo, lento, muitas vezes conflituoso, que somente atinge seu ponto culminante a partir do momento em que o indivíduo se inicia em uma profissão e assume uma relação afetiva estável. Entre as vozes que 
vão além dessas proposições, encontram-se as de Apter e Levinson. A primeira busca revogar o que ela chama de mito da maturidade, conforme o qual a idéia de estar maduro teria o sentido de ser independente. Para a psicóloga, que pesquisou sobre a evolução de indivíduos entre 18 e 24 anos, a dependência dos amores e das necessidades infantis, até determinada etapa da vida adulta, não significa necessariamente fraqueza e imaturidade. O segundo, cuja equipe entrevistou homens na faixa dos 35 aos 45 anos, defende a idéia de que o desenvolvimento é um processo contínuo, dividido em diferentes fases, e que subsiste a vida toda. $A$ concepção de Levinson, notadamente, afina-se mais com a Psicologia Analítica de Jung, para quem a individuação consiste no processo lento e imperceptível que o ser humano empreende em direção à totalidade psíquica, ou seja, o self - união harmônica e equilibrada entre consciência racional e o mundo dos instintos. No decurso da busca por esse objetivo, o homem entra em contato com os fenômenos observáveis do inconsciente, isto é, os sonhos e as visões, cujos conteúdos produzem conexões figurativas também encontradas no simbolismo da Alquimia, como defende o psicólogo suíço. Justifica-se assim parte do título desta tese, conforme se esclarece no próximo item.

\subsection{Maturidade segundo a psicologia do self}

Com relação à segunda fase, observou-se que, em $O$ relógio do mundo, de Lino de Albergaria, narra-se o processo de individuação do protagonista Casemiro Correa. A personagem central da obra empreende, durante o enredo, a busca pelo self. Para tanto, desempenha a tarefa de entrar em contato com seus conteúdos inconscientes, representados pela viagem que faz à cidade mágica de Cucura, e integrá-los à consciência, simbolizada por Cravo Branco, a cidade de origem. Ao percorrer o trajeto, o garoto é permanentemente guiado pela intuição, ou seja, por aquilo que o ser humano tem de instintivo. Essa travessia de ida e volta pode ser compreendida como uma atualização que o autor faz dos antigos ritos de passagem característicos de sociedades ditas primitivas, que tinham a função de introduzir o jovem na comunidade da tribo, da qual ele se tornava membro investido de plenos poderes, ao mesmo tempo em que adquiria o direito de se casar. Conforme explica 
Propp ${ }^{307}$, acreditava-se que, durante o rito, que acontecia sempre na parte mais densa da floresta, e no maior sigilo, o rapaz morria e ressuscitava como um novo homem. Como se pôde observar, a idéia de rito de passagem subjaz também o mito do herói, que, na Psicologia Analítica, simboliza a primeira etapa a ser cumprida pelo homem rumo à totalidade psíquica. O mito do herói revela um significado psicológico de importância fundamental tanto para o indivíduo, no seu esforço em encontrar e afirmar sua personalidade, quanto para a sociedade no seu todo, na sua necessidade semelhante de estabelecer uma identidade coletiva.

Assim, a seqüência dos fatos narrados em $O$ relógio do mundo metaforiza o processo de individuação tal qual descrito por Jung e seus seguidores. A partir do mito do herói, o indivíduo - representado no livro pelo protagonista Casemiro Correia - inicia sua caminhada para a maturidade. Dessa forma, é obrigado a abdicar das proteções que o mantinha ligado ao mundo infantil. Em sua empreitada, deverá aceitar o fato de que o conhecimento racional, por si só, não será suficiente para fazê-lo alcançar seus objetivos. Compreenderá, portanto, a necessidade de abrir-se para o conhecimento intuitivo. Essa permeabilidade irá Ihe possibilitar a entrada em contato com os conteúdos do inconsciente. Entre esses, encontra-se a anima, componente feminino na psique do homem, com o qual ele deve humildemente se harmonizar, por meio de processo que, muitas vezes, representa uma espécie de ressurreição. Não se atinge a condição de adulto senão por meio da preliminar união das polaridades negativas e positivas presentes em todos os seres, representadas pelos princípios masculino e feminino de que é composta toda a existência. Outra parte do inconsciente a ser enfrentada recebe, na psicologia junguiana, o nome de sombra. Trata-se de aspectos da própria natureza do indivíduo, aos quais, por alguma razão, ele preferiu ignorar, suprimindo-os do desenvolvimento da personalidade consciente. No entanto, é preciso reconhecê-los e aceitá-los como parte de si mesmo, para poder transmutá-los. Há ainda a necessidade de equilibrar fatores psíquicos referentes às diversas fases da vida, tendo em vista que a maturidade (senex) não implica na rejeição dos valores característicos da infância e da juventude (puer).

Resumidamente, afirma-se que, entre as condições primordiais para se enveredar pelo caminho da individuação está a necessidade de reunir na psique

${ }^{307}$ PROPP, Wladimir. As raízes históricas do conto maravilhoso. Trad. Rosemary Costhek e Paulo Bezerra. 2.ed., São Paulo, Martins Fontes, 2002, p.54. 
conteúdos conscientes e inconscientes, razão e emoção, conhecimento teórico e intuitivo, pensamento racional e pensamento mágico. Para tanto, o ser humano deve-se desprender por alguns instantes do mundo fenomênico, de modo a poder: a) integrar os princípios masculino e feminino - animus e anima; b) lançar luz sobre os componentes da sombra, e c) harmonizar as polaridades do arquétipo puersenex.

Ante o exposto, infere-se não haver evolução psíquica, espiritual, sem evolução intelectual, num contexto em que espírito seja compreendido como o lado mágico, instintivo, intuitivo da existência, e intelecto represente o desenvolvimento material. Matéria e espírito (este no sentido de totalidade psíquica) fazem parte de um todo único de existência. Nem uma parte nem outra podem arvorar-se a ter a supremacia do comando da vida. Define-se, portanto, o homem maduro como aquele que não é mais jovem, mas também não parece velho. Em outras palavras, aquele que se encontra no ápice do vigor físico, da capacidade produtiva, da argúcia intelectiva, da lucidez cognitiva e, sobretudo, na plenitude das relações afetivas.

\subsection{Maturidade segundo o contexto}

Embora a conquista da maturidade seja um processo de natureza psíquica, ou seja, com características universais e atemporais, o modo como o ser adulto se expressa no mundo está diretamente relacionado com a forma de organização social do tempo e lugar em que vive o indivíduo. Essa constatação tornou-se evidente por meio da comparação entre a obra de Lino de Albergaria, publicada no Brasil, em 1989, e a de José Gomes Ferreira, editada em Portugal, no ano de 1933. A tarefa tornou-se possível, uma vez que ambos os textos são identificados como pertencentes ao gênero literário denominado conto maravilhoso e estruturam-se a partir da representação do mito do herói e daquilo que ele expressa referentemente ao processo de passagem da adolescência para a vida adulta. A despeito das coincidências estruturais e temáticas entre as obras e das conquistas em comum dos protagonistas, notadamente as que se referem ao estabelecimento de uma relação afetiva estável e ao ingresso no mundo profissional, o encaminhamento das soluções em cada narrativa difere em razão dos contextos históricos, culturais, sociais e econômicos. Enquanto a personagem portuguesa João Sem Medo 
assume, ao "adultescer", uma postura empresarial, difundida na Europa do entre Guerras, Casemiro Correia, o herói brasileiro, adquire a consciência a respeito da necessidade de se preservar o meio ambiente, tão discutida a partir das últimas décadas no século $X X$. 


\section{Bibliografia}

\subsection{Livros}

ABERASTURY, Arminda e KNOBEL, Mauricio. Adolescência normal: um enfoque psicanalítico. Trad. Suzana Maria Garagoray. Porto Alegre, Artes Médicas, 1981.

ALBERGARIA, Lino de. Do folhetim à literatura infantil: leitor, memória, identidade. Belo Horizonte, Lê, 1996.

ANDRADE FILHO, José Hermógenes de. O que é Yoga. Rio de Janeiro, Record / Nova Era, 2004.

APTER, Terri. O mito da maturidade: o que os adolescentes precisam para se tornarem adultos. Trad. Talita M. Rodrigues. Rio de Janeiro, Rocco, 2004.

ARIÈS, Philippe. História social da criança e da família. 2.ed., Rio de Janeiro, LTC, 1981.

BETTELHEIM, Bruno. A psicanálise dos contos de fadas. Trad. Arlene Caetano. 10.reimp., Rio de Janeiro, Paz e Terra, 1980.

BLOCKEEL, Francesca. Literatura juvenil portuguesa contemporânea:

identidade e alteridade. Lisboa, Caminho, 2001.

BLOS, Peter. Adolescência: uma interpretação psicanalítica. 2. ed., São Paulo, Martins Fontes, 1998.

BRANDÃO, Junito de Souza. Mitologia grega. Vol.I, Petrópolis, Vozes, 1986.

BRUNEL, P., PICHOIS, C. e ROUSSEAU, A. M. Que é literatura comparada. Trad. Célia Berrettini. São Paulo, Perspectiva, 1985.

CALLIGARIS, Contardo. A adolescência. São Paulo, Publifolha, 2000.

CAMPBEL, Joseph. O herói de mil faces. Trad. Adail Ubirajara Sobral. 13.ed., São Paulo, Cultrix, 2008. . e MOYERS, Bill. O poder do mito. Org. Betty Sue Flowers. Trad. Carlos Felipe Moisés. Palas Athena, 1990.

CARROL, Lewis. Alice: edição comentada. Trad. Maria Luiza X. de A. Borges. Rio de Janeiro, Jorge Zahar Ed., 2002.

CASCUDO, Luís da Câmara. Dicionário do folclore brasileiro. 11. ed., rev., atual. e ilust., São Paulo, Global, 2002.

CAVALCANTI, Joana. Caminhos da literatura infantil e juvenil: dinâmicas e vivências na ação pedagógica. São Paulo, Paulus, 2002.

CECCANTINI, João Luís C. T. (org.) Leitura e literatura infanto-juvenil: memória de Gramado. São Paulo, Cultura Acadêmica; Assis, ANEP, 2004.

CHARAUDEAU, Patrick. Grammaire du sens et de l'expression. Paris, Hachette, 1992.

CHEVALIER, Jean e GHEERBRANT, Alain. Dicionário de símbolos: mitos, sonhos, costumes, gestos, formas, figures, cores, números. Trad. Vera da 
Costa e Silva, Raul de Sá Barbosa, Ângela Melim, Lúcia Melim. Rio de Janeiro, José Olympio, 1988.

COELHO, Nelly Novaes. Dicionário crítico da literatura infantil e juvenil brasileira. 5.ed.,rev., atual., São Paulo, Cia Editora Nacional, 2006.

. $O$ conto de fadas: símbolos, mitos, arquétipos. São Paulo, DCI,

2003.

2000.

Literatura infantil: teoria, análise, diática. São Paulo, Moderna,

CORSO, Diana Lichtenstein; CORSO Mário. Fadas no divã: psicanálise nas histórias infantis. Porto Alegre, Artmed, 2006.

COUTINHO, Eduardo F. Literatura comparada na América Latina. Rio de Janeiro, UERJ, 2003.

CUNHA, Antonio Geraldo da. Dicionário etimológico Nova Fronteira da língua portuguesa. 2.ed., Rio de Janeiro, 1986.

ELIADE, Mircea. Mito e realidade. Trad. Pola Civelli. São Paulo, Perspectiva, 2002.

Mercuryo, 1992.

Mito do eterno retorno. Trad. José Antonio Ceschin. São Paulo,

ERIKSON, Erik H. Childhood and Society. New York / London, W.W. Norton \& Company, 1993.

FARIA, Maria Alice. Como usar a literatura infantil na sala de aula. São Paulo, Contexto, 2004.

FERNANDES, Dirce Lorimier. A literatura infantil. São Paulo, Loyola, 2003.

FERREIRA, Aurélio Buarque de Holanda. Novo Aurélio século XXI: o dicionário da língua portuguesa. 3.ed., rev. e ampl., Rio de Janeiro, Nova Fronteira, 1999.

FERREIRA, José Gomes. Aventuras de João Sem Medo: panfleto mágico em forma de romance. 17.ed., Lisboa, Publicações Dom Quixote, 1991.

FRANZ, Marie-Louise von. O significado psicológico dos motivos de redenção nos contos de fada. Trad. Álvaro Cabral. São Paulo, Cultrix, 1993.

Trad. Jane Maria Corrêa. São Paulo, Paulus, 1992.

'Puer aeternus': a luta do adulto contra o paraíso da infância.

"O processo de individuação". In: JUNG, Carl Gustav et. alii. 0 homem e seus símbolos. Trad. Maria Lúcia Pinho. 4.ed., Rio de Janeiro, s/d.

FREYRE, Gilberto. Casa grande e senzala: formação da família brasileira sob o regime da economia patriarcal. 49. ed., rev., São Paulo, Global, 2004.

GILMORE, Robert. Alice no país do quantum: uma alegoria da física quântica. Trad. André Penido. Rio de Janeiro, Zahar, 1998.

GÓES, Lúcia Pimentel. Eros e Psique: passagem pelos portais da metamorfose. São Paulo, Humanitas / Paulinas, 2007.

Fábula brasileira ou fábula saborosa: sábia, divertida, prudente, criativa. São Paulo, Paulinas, 2005. 
Olhar de descoberta: proposta analítica de livros que

concentram várias linguagens. Ed. rev., aum. e ren., São Paulo, Paulinas, 2003.

. Em busca da matriz: contribuição para uma história da

literatura infantil e juvenil portuguesa. São Paulo, Cliper, 1998.

GREIMAS, A. J. e COURTÉS, J. Dicionário de semiótica. São Paulo, Cultrix, s/d. GULMINI, Lílian Cristina et alii. Estudos sobre o Yoga. São Paulo, CEPEUSP, 2003.

HALL, James A. Jung e a interpretação dos sonhos: manual de teoria e prática. Trad. Álvaro Cabral. 10.ed., São Paulo, Cultrix, 1998.

HENDERSON, Joseph L. "Os mitos antigos e o homem moderno". In: JUNG, Carl Gustav et. alii. O homem e seus símbolos. Trad. Maria Lúcia Pinho. 4.ed., Rio de Janeiro, s/d.

HILLMAN, James. O livro do 'puer': ensaios sobre o arquétipo do 'puer aeternus'. Trad. Gustavo Barcellos. São Paulo, Paulus, 1998.

HUNT, Peter. Children's literature. Oxford, Blackwell, 2001.

JUNG, Carl Gustav. "Chegando ao inconsciente". In: JUNG, Carl Gustav et. alii. O homem e seus símbolos. Trad. Maria Lúcia Pinho. 4.ed., Rio de Janeiro, s/d.

. Os arquétipos e o inconsciente coletivo. Trad. Maria Luiza Appy

e Dora Mariana R. Ferreira da Silva. Petrópolis, Vozes, 2000.

. Psicologia e alquimia. Trad. Dora Mariana Ribeiro Ferreira da Silva. 2.ed., Petrópolis, Vozes, 1994.

. 0 espírito na arte e na ciência. Trad. Maria de Moraes Barros. 3.ed., Petrópolis, Vozes, 1991.

. Psicologia e religião oriental. Trad. Pe. Dom Mateus Ramalho Rocha, O.S.B. São Paulo, Círculo do Livro, 1989.

Sincronicidade. Trad. Pe. Dom Mateus Ramalho Rocha, OSB. 3.ed., Petrópolis, Vozes, 1988.

. A prática da psicoterapia: contribuições ao problema da psicoterapia e à psicologia da transferência. Trad. Maria Luiza Appy. 3.ed., Petrópolis, Vozes, 1987.

Vozes, 1986.

Símbolos da transformação. Trad. Eva Stern. 4.ed., Petrópolis,

e WILHELM, Richard. O segredo da flor de ouro: um livro de vida chinês. Trad. Maria Luíza Appy e Dora Mariana R. Ferreira da Silva. Petrópolis, Vozes, 1983.

O Eu e o inconsciente. Trad. Dora Ferreira da Silva. 3.ed., Petrópolis, Vozes, 1982.

Aion: estudos sobre o simbolismo do si-mesmo. Trad. Pe. Dom Mateus Ramalho Rocha, OSB. Petrópolis, Vozes, 1982.

. O desenvolvimento da personalidade. Trad. Frei Valdemar do Amaral, OFM. Petrópolis, Vozes, 1981. 
Memórias, sonhos e reflexões: reunidas e editadas por Aniela

Jaffé. Trad. Dora Ferreira da Silva. Rio de Janeiro, Nova Fronteira, 1975.

JESUALDO. A literatura infantil. Trad. James Amado. São Paulo, Cultrix, 1982.

KLEIN, Melanie. A psicanálise de crianças. Trad. Liana Pinto Chaves. Rio de Janeiro, Imago, 1997.

LAJOLO, Marisa e ZILBERMAN, Regina. Literatura infantil brasileira: história \& histórias. São Paulo, Ática, 1984.

LEVINSON, J. Daniel et al. The Seasons of a Man's Life. New York, Ballantine Books, 1978.

MACHADO, Álvaro e PAGEAUX, Daniel-Henri. Da literatura comparada à teoria da literatura. Lisboa, Edições 70, s/d.

MEIRELES, Cecília. Problemas da literatura infantil. 4.ed., Rio de Janeiro, Nova Fronteira, 1984.

MIGUEZ, Fátima. Nas arte-manhas do imaginário infantil: o lugar da literatura na sala de aula. Rio de Janeiro, Zeus, 2003.

NARANJO, Cláudio. A criança divina e o herói: o significado interno da literatura infantil. Trad. Eneida Ludgero da Silva. São Paulo, Esfera, 2001.

OLIVEIRA, leda de (org.) O que é qualidade em literatura infantil e juvenil?: com a palavra o escritor. São Paulo, DCL, 2005.

. $O$ contrato de comunicação da literatura infantil e juvenil. Rio de Janeiro, Lucerna, 2003.

PIAGET, Jean. Seis estudos de psicologia. Trad. Maria Alice Magalhães

D’Amorim e Paulo Sérgio Lima Silva. 24 ed., Rio de Janeiro, Forense Universitária, 2002.

PROPP, Vladimir. As raízes históricas do conto maravilhoso. Trad. Rosemary Costhek Abílio e Paulo Bezerra. São Paulo, Martins Fontes, 2002.

Lisboa, Vega, 1978.

Morfologia do conto. Trad. Jaime Ferreira e Vítor Oliveira.

REIS, Carlos e LOPES, Ana Cristina M. Dicionário de narratologia. 5.ed., Coimbra, Almedina, 1996.

RESENDE, Vânia Maria de. Ziraldo e o livro para crianças e jovens no Brasil: revelações poéticas sob o signo de Flicts e reflexos prismáticos em obras de autores da língua portuguesa. f. Tese (Doutorado em Estudos Comparados de Literaturas de Língua Portuguesa) - Faculdade de Filosofia, Letras e Ciências Humanas da Universidade de São Paulo, São Paulo, 2004.

Literatura infantil e juvenil: vivências de leitura e expressão criadora. 2.ed., São Paulo, Saraiva, 1997.

SARAIVA, António José e LOPES, Oscar. História da literatura portuguesa. 17.ed., Porto, Ed. Porto, 1996.

SANTOS, Leonor Werneck. Articulação textual na literatura infantil e juvenil. Rio de Janeiro, Lucerna, 2003. 
SILVA, Vera Maria Tietzmann (org.). Vendo a vida com humor: estudos sobre Ruth Rocha. Goiânia, Cânone, 2005.

SMADJA, Isabelle. Harry Potter: as razões do sucesso. Trad. Ângela Ramalho Viana e Antônio Monteiro Guimarães. Rio de Janeiro, Contraponto, 2004.

SOUZA, Malu Zoega. Literatura juvenil em questão: aventura e desventura de heróis menores. 3.ed., São Paulo, Cortez, 2003.

SPIEGEL, L. A. "Identity and adolescence". In: LORAND y SCHNEER (comps.). Adolescence. Nova lorque, Paul Hoeber, Inc., 1961.

STAUDE John-Raphael. O desenvolvimento adulto de C. G. Jung. Trad. Humberto Arcanjo Brito Rodrigues e Sílvia Helena Azarite Vianna. São Paulo, Cultrix, 1995.

TODOROV, Tzvetan. As estruturas narrativas. Trad. Leyla Perrone-Moisés. 4.ed., São Paulo, Perspectiva, 2004.

. Introdução à literatura fantástica. Trad. Maria Clara Coelho Castello. 3.ed., São Paulo, Perspectiva, 2004.

TOWNSEND, John Rowe. Written for children: an outline of English-language children's literature. 6.ed., Lanham, Maryland, EUA, The Scarecrow Press, Inc., 1996.

VILLASANTE-BRAVO, Carmen. História da literatura infantil universal. Trad. Manuel Campos e Alexandra de Freitas. Vols. I e II., Lisboa, Vega, 1977.

WELLEK, René e WARREN, Austin. Teoria da literatura. 5.ed., Lisboa, Publicações Europa-América, 1971, pp. 57-8.

ZILBERMAN, Regina. Como e por que ler a literatura infantil brasileira. Rio de Janeiro, Objetiva, 2005.

\subsection{Internet}

A METÁFORA alquímica. IJRS, Porto Alegre, s/d. Disponível em: http://www.ijrs.org.br/artigos.php?id=8. Acesso em: 5 fev. 2007.

ACTION on ozone. UNEP Secretaria do Ozônio. Programa das Nações Unidas para o Meio Ambiente. Nairobi, nov. 1996. Disponível em: http://www.ambiente.sp.gov.br/prozonesp/Actiozon/0z0100.htm. Acesso: em 13 mar. 2007.

DESAFIO do século XXI: desenvolvimento com preservação ambiental. Vermelho. "Revista Princípios". São Paulo, $\mathrm{n}^{\circ}$. 83. s/d. Disponível em: http://www.vermelho.org.br/museu/principios/anteriores.asp?edicao=83. Acesso em: 13 mar. 2007.

ENTENDA o Protocolo de Kyoto. Época on line. Rio de Janeiro, mai. 2006. Disponível em: http://revistaepoca.globo.com/Epoca/0,6993,EPT908417-16551,00.html. Acesso em: 13 mar. 2007.

FUTURISMO. História da arte. http://www.historiadaarte.com.br/futurismo.html. Acesso em: 12 abr. 2008. 
HISTÓRIA dos Incas. Sua pesquisa.com Disponível em:

http://www.suapesquisa.com/pesquisa/incas.htm. Acesso em: 21 fev. 2007.

MONTE ALEGRE, a mais antiga morada do homem das Américas. Amazon view. Disponível em:

http://www.inteligentesite.com.br/modelos/modelo70/subconteudo.asp?ID=358\&IDS UBLINK=1874. Acesso em: $21 \mathrm{fev} .2007$.

O PROTOCOLO de Kyoto. Greenpeace. São Paulo, s/d. Disponível em:

http://www.greenpeace.org.br/clima/pdf/protocolo kyoto.pdf. Acesso em: 13 mar. 2007.

BALLONE G.J. Síndrome de Don Juan e o hábito de 'ficar'. PsiqWeb Psiquiatria Geral. Campinas, dez. 2004. Disponível em:

http://www.psiqweb.med.br/sexo/donjuan.html. Acesso em: 4 mar. 2007.

BARBOSA, Ivanilda. A escrita paterna e o desvelamento de sentido em Uma noite em Curitiba. Estudos de Literatura Brasileira Contemporânea, n.7. Brasília, maio/junho de 2000, pp. 11-21. Cristóvão Tezza. Disponível em:

http://www.cristovaotezza.com.br/critica/trabalhos acd/f artigos/a\%20escrita\%20pat erna.htm. Acesso em: 10 set. 2006.

CUNHA, Maria Teresa Santos. Mulheres e romances: uma intimidade radical.

Scielo Brasil, Cadernos CEDES. Campinas, jul. 1998. Disponível em:

http://www.scielo.br/scielo.php?pid=S0101-32621998000200007\&script=sci arttext.

Acesso em: 26 ago. 2006.

DEBORD, Guy. A sociedade do espetáculo. Pausa para a Filosofia. Disponível em: http://br.geocities.com/mcrost12/a sociedade do espetaculo 1.htm. Acesso em: 20 ago. 2006.

DUENDES. A casa do bruxo: textos sobre magia e esoterismo. s/d. Disponível em: http://www.casadobruxo.com.br/textos/duendes.htm. Acesso em: 26 jan. 2007.

EGITO, José Laércio de. Mistérios nos números: peculiaridade no número três. José Laércio do Egito - FRC. Disponível em:

http://www.joselaerciodoegito.com.br/site tema389.htm. Acesso em: 30 jan. 2007.

GENTE. Caetano Veloso. Disponível em:

http://www.caetanoveloso.com.br/sec busca obra.php?language=pt BR\&id=51\&sec discogra todas=1. Acesso em: 6 set. 2006.

GHIRARDI, Pedro Garcez. O relato de Marco Pólo e a Nova Floresta de Bernardes. Disponível em: http://www.hottopos.com.br/notand5/marcpolo.htm. Acesso em: 27 nov. 2006.

HAMILTON, Calvin J. Netuno. Vistas do sistema solar. Disponível em: http://www.if.ufrgs.br/ast/solar/portug/neptune.htm\#intro. Acesso em: 11 out. 2006.

JAPPE, Anselm. A arte de desmascarar. A sociedade do espetáculo: um dos principais libelos contra o capitalismo. Pausa para a Filosofia. Disponível em: http://br.geocities.com/mcrost12/a sociedade do espetaculo 0.htm. Acesso em: 20 ago. 2006.

JUPITER. Gaiastral. Disponível em: http://www2.uol.com.br/gaiastral/peixes/planeta.shl. Acesso em: 11 out. 2006. 
LÓSSIO, Rúbia. Tangolomango. Dicionário de folclore para estudantes. Fundação Joaquim Nabuco. s/d. Disponível em:

http://www.soutomaior.eti.br/mario/paginas/dic t.htm. Acesso em: 19 jan. 2007.

RABELLO, Elaine e PASSOS, José Silveira. Erikson e a teoria psicossocial do desenvolvimento. Portal Brasileiro de Análise Transacional, Rio de Janeiro. Disponível em: http://www.josesilveira.com/artigos/erikson.pdf. Acesso em: 17 set. 2007.

SATURNO. Gaiastral. Disponível em:

http://www2.uol.com.br/gaiastral/aquario/planeta.shl. Acesso em: 11 out. 2006.

VOLPATTO, Rosane. Anões e gnomos. Reino das deusas. Porto Alegre, s/d.

Disponível em: http://www.rosanevolpatto.trd.br/anoesgnomos.html. Acesso em: 28 de jan. 2007.

\subsection{Jornais}

LEITE, Marcelo. A culpa é nossa. Folha de S. Paulo, São Paulo, 3 fev. 2007. "Caderno Especial Clima", p. 1.

MAUTNER, Ana Verônica. Aprenda nos romances. Folha de S. Paulo, São Paulo, 20 set. 2007. "Folha Equilíbrio".

SAYÃO, Rosely. A responsabilidade dos pais. Folha de S. Paulo, São Paulo, 7 dez. 2006. "Folha Equilíbrio", p.12.

SAYÃO, Rosely. Que cidadania é essa? Folha de S. Paulo, São Paulo, 6 abr. 2006. "Folha Equilíbrio", p.12 


\section{Apêndice: a obra de Lino de Albergaria}

\subsection{Leitor crítico}

Grandes transformações ocorrem na passagem da pré-adolescência para a adolescência inicial e, dessa, para a adolescência propriamente dita. Trata-se de fase complexa em que indivíduos de ambos os sexos são mais profundamente afetados pelas mudanças que ocorrem em seus corpos. Embora os psicanalistas sejam renitentes em estabelecer um paralelo direto entre desenvolvimento fisiológico e predisposições mentais, eles não deixam de reconhecer, entretanto, que o crescimento anatômico reflete de maneira significativa no comportamento dos jovens.

A necessidade de abrir-se para o mundo, associada à experiência de romper paulatinamente os laços emocionais com a família, provoca receios, inseguranças e até mesmo excitações muito fortes no adolescente. A compreensão definitiva do final da infância e da natureza irrevogável dos compromissos da vida adulta torna a adolescência um dos períodos simultaneamente mais profícuos e difíceis da existência humana. Dada a complexidade da transição, nota-se nos jovens grande diversidade de reações ante a iminência do processo, conforme esclarece Blos $^{308}$.

\footnotetext{
Testemunhamos na adolescência um segundo passo para a individuação, tendo o primeiro sido dado por volta do final do segundo ano, quando a criança experimenta uma distinção entre o "eu" e o "não-eu". Uma individuação semelhante, e muito mais complexa, ocorre durante a adolescência, que leva em seu passo final a um senso de identidade. [...] Os impulsos de oposição, de rebelião e de resistência, as etapas de experimentação, as provas a que o eu é submetido pela prática de excessos - tudo isso tem uma utilidade positiva no processo de autodefinição.
}

No período da adolescência, a maior parte da energia do jovem está canalizada para compreender o que se passa consigo mesmo e que papel deve desempenhar no contexto social que o cerca. Nesse sentido, a busca por

${ }^{308}$ BLOS, Peter. Adolescência: uma interpretação psicanalítica. 2.ed., São Paulo, Martins Fontes, 1998, p.19. 
referências comportamentais e novos valores ocupa quase que integralmente sua capacidade criativa. Decorre daí, em princípio, uma forte onda de amizades íntimas e idealizadoras, seguida, posteriormente, pelo sentimento de estar apaixonado. Concomitantemente, surge a preocupação com problemas filosóficos, políticos e sociais, quase sempre acompanhada por sensações de angústia e culpa, em decorrência da constatação a respeito das dificuldades do caminho para o amadurecimento.

Em virtude de experimentar um momento de indefinição por excelência, o estado de espírito do adolescente pode apresentar flutuações entre polaridades bastante extremadas. Da sujeição à rebelião, do sentimento gregário ao retraimento para a solidão, da amabilidade à grosseria, do egoísmo ao altruísmo, do movimento à inércia, do idealismo à mesquinharia, do ascetismo ao materialismo, entre outras alternâncias, vários padrões de atitudes podem ocorrer em curto espaço de tempo. O processo de resolução das ambigüidades, no entanto, na maioria das vezes ultrapassa em muito os limites etários aos quais os estudiosos circunscrevem a adolescência. Nos dias atuais, como são grandes os obstáculos a serem vencidos, muitos indivíduos, ainda que inconscientemente, apresentam tendência a permanecerem de modo indefinido nessa fase transitória. A respeito do assunto, recorre-se ao que diz Coelho ${ }^{309}$ :

[...] nesta época de transformações em que vivemos, os caminhos gratificantes para cada indivíduo não são fáceis de serem encontrados. Os estímulos são muitos, na maior parte contraditórios, pois o caos dos valores ainda perdura como marca de nosso mundo. Entretanto, novos valores já estão em gestação e a nova literatura aponta para eles.

Sob esse aspecto, ao abordar os conflitos típicos da adolescência de forma sempre otimista, Lino de Albergaria, por meio de seus textos literários, busca contribuir para que os jovens encontrem os tais novos valores apontados por Coelho. São vários os títulos do autor voltados especialmente para os adolescentes.

${ }^{309}$ COELHO, Nelly Novaes. Literatura infantil: teoria, análise, didática. São Paulo, Moderna, 2000, p. 39. 


\subsubsection{Cabelos de fogo, olhos de água. Co-autoria de SOUZA, Angela}

Leite de. Ilustrações Mariângela Haddad. São Paulo, Cortez. 103 p.

(c) 2006 - Leitor crítico. Realismo crítico e humanitário.

$\mathrm{Na}$ cultura ocidental, a falta de rituais institucionalizados para marcar a fase de transição dos jovens da puberdade para a pré-adolescência, se, de um lado, permite a busca por soluções individualizadas para a o desenvolvimento da personalidade, de outro, pode facilitar a evolução psíquica anormal e patológica decorrente de uma sobrecarga de autodeterminação.

Um exemplo desse desvio observa-se no tipo de comportamento apresentado pela personagem Antônio Barbosa (o Tonhão, que aparece também em Urano $x$ Netuno). Extremamente determinado, o garoto comunica-se de forma agressiva, como se a entender que sua vontade devesse prevalecer sempre sobre a dos demais. É o caso específico de quando tenta tirar à força Letícia Bárbara (aluna nova na classe da sexta série) da carteira na qual ela estava sentada. Repare-se no tom que ele usa:

— Fique sabendo que esse lugar é meu. Pode ir juntando suas coisas. [...]

— E aí, ô menina? Vai saindo, anda, ou vai querer que eu perca a paciência? ${ }^{310}$

$\mathrm{Na}$ faixa etária em que se encontram, meninos hostilizarem meninas é fato relativamente normal. "Em essência, o menino nega sua ansiedade, em lugar de procurar estabelecer uma relação. A ansiedade de castração que provocou o declínio da fase edípica reaparece e força o menino à companhia exclusiva de seu próprio sexo", esclarece Blos ${ }^{311}$. Não tão comum, entretanto, é a forma violenta como age Antônio. Mas Letícia sabe reagir, está longe de ser indefesa e chorona. 'Na menina, essa fase caracteriza-se por uma 'onda de atividade', durante a qual as representações e as atitudes masculinas chegam ao auge." ${ }^{312}$ Note-se como ela responde:

\footnotetext{
${ }^{310}$ Cabelos de fogo, olhos de água, pp. 6-7.

${ }^{311}$ BLOS, Peter. Adolescência: uma interpretação psicanalítica. 2.ed., São Paulo, Martins Fontes, 1998, p. 82.

${ }^{312}$ Idem, ibidem, p. 82.
} 
— Não levanto, seu mal-educado! ${ }^{313}$

O episódio irá deflagrar total dissensão dentro da sala de aula e resultará na divisão da classe em duas turmas bastante distintas: o Bonde do Tonhão e a Liga das Mulheres. Como os próprios nomes sugerem, os blocos se agrupam com base nos gêneros masculino e feminino, com algumas dissidências. Estava declarada a guerra, em substituição a qualquer rito padronizado de passagem para estágios mais evoluídos de convívio humano. A sociedade contemporânea, cujas formas de relacionamento são completamente influenciadas pelos meios de comunicação de massa, favorece racionalizações, formações de reação e certa sexualização ditadas mais por interesses econômicos do que por critérios de compreensão e aceitação das diferenças. Dessa forma, o espírito competitivo e a agressividade dos adolescentes apenas refletem o modelo de comportamento social da cultura a que eles pertencem. Entregues a si mesmos, os jovens formam espontaneamente organizações competitivas dentro de suas próprias fileiras.

Quadrilhas, grupos e turmas para todos os propósitos e unificadas por todos os tipos de princípios, colocam-se umas contra as outras: sua ênfase é a dominação agressiva, a superioridade competitiva e a exclusividade hostil. $\mathrm{Na}$ estrutura desses grupos adolescentes opera um princípio de dois valores, segundo o qual as atitudes (ética) válidas dentro do grupo, mas não fora dele, não são vistas como contradições morais. ${ }^{314}$

Em Cabelos de fogo, olhos de água, o contraste semântico expresso pelas locuções adjetivas do título já indica, de certa forma, a temática de combate em que se baseia a narrativa. Também os apelidos pejorativos por meio dos quais os alunos se identificam uns aos outros trazem as marcas do estigma e da desconsideração que permeiam as relações. Nessas circunstâncias, o princípio de dois valores que rege cada uma das turmas que participam do enredo apenas será revisto após acarretar conseqüências negativas não só para as partes envolvidas, como também para os demais indivíduos no em torno das ações: a diretora da escola, os professores, os pais e até mesmo um mico de estimação, Francis Nicolai, o

${ }^{313}$ Cabelos de fogo, olhos de água, p. 7.

${ }^{314}$ BLOS, Peter. Adolescência: uma interpretação psicanalítica. 2.ed., São Paulo, Martins Fontes, 1998, p. 273. 
Chiquinho. Conclui-se da leitura que, muitas vezes, o preço para se evoluir no interior de uma cultura sem ritos é um tanto quanto elevado.

\subsubsection{O menino e o mar. Ilustrações de Rogério Coelho. São Paulo,} Saraiva, 2005. 64 p.

(C) 2004 - Leitor crítico. Realismo crítico.

Naquela tarde, o irmão de Edmilson não voltou para casa. Edivan tinha viajado para São Paulo. la trabalhar por algum tempo, juntar dinheiro, e depois voltava. Pelo menos era isso o que dissera seu Edivaldo, o pai, um tanto quanto nervoso. A mãe, dona Eulina, mal disfarçava o choro.

O garoto estranhou o fato de o irmão ter partido sem se despedir. Até imaginou que Edivan poderia trabalhar ali mesmo, assim como ele, que havia começado naquele dia a vender queijo de coalho na praia. Sabia que o trabalho era proibido para criança. Alguém podia tentar impedir. Afinal, ele só tinha dez anos. Mesmo assim, resolveu arriscar. A bandeja e a lata de carregar brasas tinha alugado do Borracha, para pagar depois. Os espetinhos com queijo vieram do dinheiro da mãe, que o havia emprestado com uma condição: recebê-lo de volta no mesmo dia, pois precisava comprar açúcar.

A saudade e a forma inesperada como o irmão havia se ausentado despertaram em Edmilson, no entanto, em vez de mágoa, a imaginação. Ante as poucas explicações dos pais e a curiosidade dos colegas de escola, inventou que Edivan tinha ido a São Paulo para se tornar marinheiro. A história só não causou maior admiração entre os meninos, por causa de Inezília. Foi ela quem alertou para o fato de que em São Paulo não havia mar. A informação caiu feito uma bomba em meio à conversa. A discussão foi tanta, que a menina buscou o apoio da professora. Para a sorte do garoto, dona Givalda contornou a situação. Explicou que a cidade de São Paulo não tinha mar, mas o Estado, sim, tinha litoral e seu principal porto ficava na cidade Santos.

São Paulo, Santos, na cabeça do rapaz tanto fazia a cidade. O importante era manter acesa a crença de que irmão realizava um grande sonho: o de conhecer o outro lado daquele imenso mar. Um sonho que, na realidade, era o dele. Fosse dormindo, fosse acordado, Edmilson sonhava. Um dia, seguiria os passos de Edivan 
e, como ele, viveria no mar, seria capitão. la longe a imaginação do garoto, tentando alcançar o futuro, sem, no entanto, deixar de viver o presente.

Desejos bem mais modestos também faziam parte de seu dia-a-dia. Ir à escola, divertir-se com os amigos, desfrutar sozinho do sofá de casa, assistir a desenhos animados na televisão, torcer para que seu Edivaldo não bebesse e que o pai e a mãe não brigassem estavam ainda entre suas aspirações. Com o lucro do trabalho, o que mais queria era comprar uma bermuda nova e a mochila que tinha visto na feira: a única estampada com o passarinho de seu desenho animado favorito. Edmilson identificava-se tanto com aquela pequena ave, que nem se importou quando Inezília disse que o desenho era coisa de criança. Em discurso indireto livre, o narrador expressa o pensamento do garoto:

[...] Ela não entendia era nada. Aquele passarinho era esperto, era danado, era livre. Sabia muito bem escapar do gato. Só era pequeno. Ser pequeno não é ser bobo. ${ }^{315}$

Embora não explícita, é impossível não relacionar a referência ao desenho animado Piu Piu e Frajola. Era exatamente como Piu Piu que Edmilson se sentia: pequeno, mas esperto, nem um pouco incapaz de entender o mundo dos adultos. Havia aprendido a preparar com capricho os espetinhos de queijo. Além disso, as tardes passadas na praia, carregando a bandeja e o fogareiro, rendiam mais do que algum dinheiro. Vendendo queijo, ele conheceu Nádia, a menina russa que despertara nele a primeira atração pelo sexo oposto. Foi também trabalhando que fez amizade com Cezar, o fotógrafo careca, "meio parecido com a Lua" ${ }^{316}$, que certo dia viera à praia usando um quepe de marinheiro.

Marinha, Lua, Rússia, o que não faltavam no cotidiano do garoto eram representações daquilo com que ele andava sonhando, ou seja, com o longínquo e o desconhecido. Mas o que parecia tão distante, tão momentaneamente inatingível, não passava de metáfora para sua verdadeira busca: crescer simplesmente. Pois foi ali mesmo, naquele pequeno lugarejo não identificado do litoral brasileiro, que circunstâncias favoráveis criaram as condições para esse crescimento.

\footnotetext{
${ }^{315}$ O menino e o mar, p. 43

${ }^{316}$ Ibidem, p. 22.
} 
Uma forte decepção fez diminuir em importância o sonho de ser marinheiro, que já podia ser substituído por outro(s) igualmente fascinante(s). O sentimento de amizade criou o ensejo para a descoberta de valores éticos e a oportunidade para a realização de um ato de heroísmo. O despertar do afeto sinalizou o caminho dos primeiros passos em direção ao entendimento do universo feminino e dos conflitos familiares.

A história de Edmilson, de O menino e mar, ilustra de maneira sensível, e com sutis questionamentos sociais, a passagem da puberdade para a pré-adolescência. Entre os fatores psicológicos abordados, evidenciam-se a difícil tarefa de lidar com a ansiedade do "vir a ser" e, sobretudo, o momento mesclado de prazer e dor pela compreensão de que o herói, projetado no outro, na realidade vive dentro de si.

\subsubsection{Urano x Netuno. Co-autoria de SOUZA, Angela Leite de. Ilustrações de Angela Leite de Souza. Belo Horizonte, Assembléia Legislativa do Estado de Minas Gerais, 2003. 72 p.}

\section{(c) 2003 - Leitor crítico. Realismo crítico e humanitário.}

De acordo com a mitologia grega, no princípio de tudo, existia o nada, um espaço imenso e árido. Depois, desponta o Caos, completamente desorganizado. Aparece então Géia (a Terra), a primeira realidade sólida. Géia cria um companheiro: Urano (o Céu). Os dois se amam e, dessa união, surgem os elementos primordiais: fogo, terra, ar e água. Assim, o caos torna-se organizado e passa a chamar-se Cosmos. Urano é, portanto, considerado o pai de todas as criaturas. Na Astrologia, Urano representa a capacidade humana de adaptação às mudanças exteriores, por meio da libertação das amarras e superação dos preconceitos que impedem a evolução individual. ${ }^{317} \mathrm{Em}$ astronomia, Urano é o sétimo planeta a partir do Sol. Foi descoberto por William Herschel, em 1781. Tem um diâmetro equatorial de 51.800 quilômetros e orbita o Sol a cada 84,01 anos terrestres. ${ }^{318}$

Ao lado de Urano, está Netuno, o oitavo planeta, cujo diâmetro equatorial é de 49.500 quilômetros. Se fosse oco, poderia conter cerca de 60 Terras. Orbita o Sol a

${ }^{317}$ SATURNO. Gaiastral. Disponível em: http://www2.uol.com.br/gaiastral/aquario/planeta.shl. Acesso em: 11 out. 2006.

${ }^{318}$ HAMILTON, Calvin J. Netuno. Vistas do sistema solar. Disponível em:

http://www.if.ufrgs.br/ast/solar/portug/neptune.htm\#intro. Acesso em: 11 out. 2006. 
cada 165 anos. Tem oito luas, seis das quais foram descobertas pela sonda espacial Voyager. Um dia em Netuno dura 16 horas e 6,7 minutos. O planeta foi descoberto em 23 de setembro de 1846 por Johann Gottfried Galle, do Observatório de Berlim, e Louis d'Arrest, um estudante de astronomia, através de predições matemáticas feitas por Urbain Jean Joseph Le Verrier. ${ }^{319}$

Netuno, para os romanos, Poseidon, para os gregos, é filho de Saturno (Cronos) e Cibele (Réia). Depois de uma guerra entre os deuses, o mundo foi dividido. Coube a Netuno o mundo dos mares. Sua função era ter a supremacia dos oceanos, das ondas e das correntes. Também provocava tempestades, abalava os rochedos e fazia brotar fontes de água, golpeando a terra com seu tridente. $\mathrm{Na}$ Astrologia, Netuno está associado aos sonhos, às fantasias, mas também às buscas espirituais. Simboliza ainda flutuações psíquicas, desfavorecimentos, sacrifícios, inspiração artística, entre outros fenômenos. ${ }^{320}$

Assim como Urano e Netuno são planetas vicinais do sistema solar, neste livro de Lino de Albergaria, escrito a quatro mãos com Angela Leite de Souza, são nomes de edifícios vizinhos, em alguma cidade do Brasil, onde moram várias crianças em fase de transição da puberdade para a pré-adolescência. $O$ comportamento gregário é característica típica desse período.

[...] O indivíduo adolescente vive sempre dentro de um grupo de companheiros de idade que variam muito quanto ao desenvolvimento físico e aos interesses. Essa condição é responsável pelas muitas formas de comportamento imitativo e "como se", a que os adolescentes recorrem a fim de se manterem dentro do padrão esperado de conduta e protegerem a compatibilidade social com o grupo a que pertencem. ${ }^{321}$

Na história em questão, os grupos são formados pela idéia de pertencimento a este ou àquele prédio e pela opção por esta ou aquela competição esportiva. Dessa forma, duas turmas - uma do edifício Urano, outra do Netuno - enfrentamse na disputa pelo único terreno baldio das redondezas, para suas práticas. A primeira sente-se no direito exclusivo de jogar futebol no local, apenas pelo fato de

319 Idem, ibidem.

320 JUPITER. Gaiastral. Disponível em: http://www2.uol.com.br/gaiastral/peixes/planeta.shl. Acesso em: 11 out. 2006.

${ }^{321}$ BLOS, Peter. Adolescência: uma interpretação psicanalítica. 2.ed., São Paulo, Martins Fontes, 1998. p. 12. 
ser um pouco mais antiga no bairro. A segunda, por entender que o espaço não tem dono, insiste em jogar queimada no mesmo campinho.

Conflito armado, desenvolve-se a narrativa, cujo tema lembra o da clássica novela juvenil Os meninos da rua Paulo, do húngaro Ferenc Molnár, publicada em 1907 (no Brasil, em 1952), na qual duas turmas de adolescentes brigam por uma área livre na cidade de Budapeste. A semelhança entre as duas obras está apenas na trama central, ou seja, na rivalidade por razão similar. As diferenças, no entanto, são muitas, especialmente por conta do contexto sócio-histórico, geográfico e temporal em que se dá o desenvolvimento das ações. Se na obra de Ferenc o encaminhamento das soluções passa, necessariamente, pela deflagração de uma guerra, no texto de Albergaria e Souza declara-se explicitamente a intencionalidade educativa dos patrocinadores da publicação. Editado pela Assembléia Legislativa do Estado de Minas Gerais, o livro é apresentado dentro de uma caixa e traz, como anexos, o jogo da cidadania e uma carta ao estudante, assinada pelo então presidente da casa, o deputado Mauri Torres. Em um trecho, diz o parlamentar:

[...] queremos dividir com você a lição da convivência com os contrários e com as diferenças. Um aprendizado que é permanente, que vai acompanhar você pelo resto da vida e que vai influir na sua relação com seu próximo, sua cidade, sua região, seu Estado, seu País.

Para além das questões territoriais, os autores exploram as diferenças humanas, ao criarem um enredo em que vários padrões comportamentais de adolescentes da classe média brasileira estão representados, com destaque para a anulação da oposição de papéis sociais entre masculino e feminino.

\subsubsection{Chico, Edu e a oitava série. Ilustrações de Marco Aragão. São Paulo, Saraiva, 2002. 134 p.}

(c) 2002 - Leitor crítico. Realismo humanitário.

O conjunto de quatro livros nos quais Lino de Albergaria aborda 0 desenvolvimento dos adolescentes, a partir do cotidiano da mesma escola de classe média, encerra-se com este Chico, Edu e a oitava série. Em cada uma das obras, o leitor conhece os conflitos individuais e familiares de uma personagem principal, que também narra a história, e acompanha os desdobramentos das relações entre o 
grupo central de alunos. As outras obras são: Miguel e a quinta série, Lia e a sexta série, Márika e a sétima série.

A peculiaridade deste é a presença dos irmãos que se alternam no papel de narradores, de modo a oferecer ao leitor duas focalizações do universo diegético, bem como duas maneiras diferentes de sentir o mundo e encarar o crescimento psicológico, de acordo com a personalidade em formação de cada protagonista. A busca da individualidade é o tema central do enredo, cujo núcleo principal é uma família formada por dois pares de gêmeos. Além de Chico e Edu, coabitam o mesmo lar Betânia e Nara, mais velhas que os meninos. São os quatro filhos de Otávio e Leonora, batizados com os nomes de conhecidos compositores e cantoras da Música Popular Brasileira.

O pai, de perfil autoritário, e a mãe, de natureza mais relaxada, apesar de conscientes do papel que devem desempenhar como educadores, pouco conseguem estar atentos aos problemas por que passam os jovens. Há o fato de Nara, mais rebelde e atirada, envolver-se com um rapaz mais velho, mulherengo, modelo profissional, vizinho do prédio ao lado. Mas o núcleo da trama gira em torno da atração que Edu e Chico sentem pela mesma garota: Sandra, deficiente visual, que mora no mesmo edifício.

Chico é bastante apegado a Nara, enquanto que Edu e Betânia têm temperamentos parecidos. São mais calmos, mais ponderados, mais intimistas. No início da oitava série, Chico e Edu ainda vivem uma espécie de simbiose comportamental. O fato de serem tão parecidos fisicamente havia criado forte identificação entre eles, algo como se pensassem da mesma maneira, sentissem do mesmo modo, interpretassem as mesmas situações de forma igual. Os primeiros sinais de mudança começam a aparecer no rosto. Chico tem mais espinhas do que Edu. Logo a diversidade é observada também na percepção da realidade. Quando o professor de Matemática, o Rocha, é substituído por Regiane, Chico não só não aceitou bem a troca como ficou surpreso, e até um pouco magoado, com o fato de Edu gostar da nova professora. Mas a compreensão de fato a respeito da identidade de cada um só virá lentamente, no decorrer de todo o ano letivo, justamente por conta do encontro diário com Sandra.

Articulada de modo a criar suspense sobre a preferência da garota cega, a narrativa revela pouco a pouco como cada um dos irmãos sente a quebra da união. Chico conta: 
Olhei para o Edu. Ele me devolveu o olhar. A gente não precisou dizer nada. Cada um estava agora convencido do que aquela menina, sentada à nossa frente, significava um para o outro. ${ }^{322}$

Ao perceber que um período da vida se encerra com a formatura na oitava série, Edu pensa:

Ou o final deste ciclo está mesmo dentro de casa? É ver meu irmão se transformando no meu rival? Pois junto de nossas espinhas, vem essa disposição de querer ter uma menina para se gostar dela. Como somos gêmeos, temos de escolher a mesma! Por mais estranha e imprevisível que possa parecer essa escolha. ${ }^{323}$

Imprevisível, para o leitor, é com quem Sandra irá ficar. Isto porque, até quase o final da história, as atitudes da garota são dúbias com relação aos rapazes. As ações narradas também despertam curiosidades a respeito de como reagirá o irmão preterido. Como em Esaú e Jacó, de Machado de Assis, romance explicitamente citado no texto, o autor mantem o suspense até o final.

\subsubsection{Márika e a sétima série. Ilustrações de Marco Aragão. São Paulo, Saraiva, 2002. 126 p.}

(c) 2002 - Leitor crítico. Realismo humanitário.

Márika e a sétima série é o terceiro de um conjunto de quatro livros nos quais, a partir do cotidiano de uma escola classe média, são desenvolvidos enredos que abordam o processo de desenvolvimento psicológico de jovens que cursam o segundo ciclo do ensino fundamental. Os outros três são: Miguel e a quinta série, Lia e a sexta série, Chico, Edu e a oitava série. Em cada uma das obras, o leitor acompanha os conflitos individuais e os problemas coletivos de relacionamento típicos dessa faixa etária. Algumas personagens transitam por todas as histórias, enquanto outras entram ou saem, de modo a compor um painel bastante verossímil.

\footnotetext{
${ }^{322}$ Chico, Edu e a oitava série, p. 91.
}

${ }^{323}$ Ibidem, p. 96. 
Neste, a protagonista-narradora é uma garota da República Tcheca que vem morar no Brasil com o pai, Márek, depois que Ludmilla, a mãe, assume um caso amoroso com o irmão do marido. A presença de Márika na turma já era notada desde a série anterior, quando, por ser novata no colégio, estrangeira e ter um tipo físico com características meio masculinas, havia sido alvo de algumas manifestações preconceituosas, tanto de indiferença quanto de agressão.

Basicamente, são dois os desafios enfrentados por essa menina tcheca: adaptação a uma nova cultura e a relação com o pai. No primeiro caso, notam-se as dificuldades com a Língua Portuguesa, a falta de um referencial histórico comum aos demais alunos, o estranhamento com os modos do povo brasileiro. Entre esses, destacam-se a intimidade escancarada, a rápida tomada de liberdades com o outro, o jeito algo deslumbrado de reverenciar os Estados Unidos, especialmente Miami, a falta de conhecimento sobre assuntos e locais importantes do próprio país, o gosto exagerado por açúcar. Questões essas que, de um jeito ou de outro, Márika consegue contornar.

Já no que se refere ao convívio com o pai, aí, sim, os transtornos da garota serão verdadeiramente intensos. Desterrada de sua Praga natal, distanciada da amiga Vera e demais companheiros de infância, o afeto da adolescente voltava-se de maneira quase que doentia para Márek. Pesava também o fato de culpar Ludmilla pelo desmantelamento da família. No entender de Márika, as mudanças tão radicalmente ocorridas em sua vida tinham como única causa a traição da mãe. $\mathrm{O}$ pai, por sua vez, gostava de reforçar essa forma de sentir da filha. Não é preciso ir mais longe, portanto, para compreender a que grau chegava o complexo de Édipo da menina. Um dos sintomas visíveis era a implicância que tinha com a presença de Eliane, a namorada de Márek. Repare-se na cena de ciúme:

\section{— Não quero que ela durma aqui!}

Márek me abraçou e me prometeu:

- Se você não quiser, ela não dorme!

E eu me senti muito mais importante que a Eliane. ${ }^{324}$

${ }^{324}$ Márika e a sétima série, p. 36. 
Ela sentiu-se mais importante de que a Eliane e, até mesmo, de que a própria mãe, já que viera com o pai para o Brasil. Sob a ótica da psicanálise, Blos ${ }^{325}$ esclarece:

[...] O envolvimento edípico surge na atitude crítica do adolescente para com um dos pais; na menina, é mais freqüente que seja a mãe o alvo das censuras e acusações. Muitas meninas estão convencidas de que compreendem o pai melhor do que a mãe pode compreendê-lo.

Decorre daí a necessidade que toda menina tem de ser amada, e até certo ponto desejada, pelo pai. Segundo Diana e Mario Corso ${ }^{326}$, as "artes de sedução da mulher se aprendem através de um jogo que não pode ser realizado com o pai, mas pode muito bem ser ensaiado." Ainda de acordo com o casal de estudiosos, "um pai que não dedique um olhar para sua filha a deixa sem armas para o futuro jogo amoroso fora de casa." Isso explica o fato de, no início da história, Márika apresentar-se totalmente destituída de vaidade e feminilidade, já que o pai não nota o amadurecimento da filha. Ela parece tanto saber dessa função paterna, que chega a explicitar a própria carência.

Meu pai. Às vezes penso que ele podia reparar mais em mim. Comentávamos da festa, mas ele não percebeu que eu usava um vestido. ${ }^{327}$

Para Márek, a guarda da filha, que havia conseguido legalmente em seu país, talvez representasse mais uma forma de castigar a ex-mulher do que uma verdadeira opção por criar a menina. É uma mistura de amor e posse que se revela em seus sentimentos, especialmente quando esconde uma carta de Ludmilla para a filha, dando conta de que a mãe esperava uma criança. Como se percebe, é num ambiente de afetos conturbados, numa terra estranha, que Márika atinge a adolescência propriamente dita. Para quem é de natureza fechada, que não se abre com pessoas pouco conhecidas, imagine-se a complexidade da situação.

${ }^{325}$ BLOS, Peter. Adolescência: uma interpretação psicanalítica. 2.ed., São Paulo, Martins Fontes, 1998, p. 144.

${ }^{326}$ CORSO, Diana Lichtenstein; CORSO Mário. Fadas no divã: psicanálise nas histórias infantis. Porto Alegre, Artmed, 2006, p. 96.

${ }^{327}$ Márika e a sétima série, p. 54 . 
A sorte da garota é o amor que sente pelas artes plásticas, a inclinação que descobre para o desenho, para a xilogravura. Insegura com uso das tintas e das cores, a princípio, a garota faz surgir de fundos pretos e infinitos, simbólicos do inconsciente, fantasmagóricas imagens femininas. A descrição que se tem das telas remete a alguns dos sombrios e assombrosos espectros de Iberê de Camargo. Aos poucos, entretanto, o preto vai dando lugar ao marrom, que por sua vez cede aos tons dourados. Forma-se, então, o auto-retrato completo. É por meio da pintura que Márika vai se manifestar e se reconhecer como mulher, na qual irá identificar profundas marcas deixadas pela mãe. Desvendam-se, daí, novos questionamentos, para os quais ela terá de ir buscar novas respostas. É ler para saber.

Ainda sobre Márika e a sétima série, vale comentar algumas referências históricas e geográficas presentes na obra, que podem motivar algum tipo de atividade didática. Com relação ao Brasil, encontram-se, por exemplo, menções às cidades de Ouro Preto e Recife. Já no diz respeito à República Tcheca, pode-se remeter à Primavera de Praga, experimento de "socialismo com face mais humana", entre os países do outro lado da Cortina de Ferro, sufocado no ano de 1968. A alusão é sutil, mas se dá em um sonho de Márika.

Tinha sonhado com minha outra escola, no meu país, num dia de primavera. [...] É que tinha escutado alguém comentando que a primavera iria começar. Mas eu ainda não conseguia entender o que significa uma primavera no Brasil. ${ }^{328}$

7.1.6 Lia e a sexta série. Ilustrações de Marco Aragão. São Paulo, Saraiva, 2002. $96 \mathrm{p}$.

(C) 2002 - Leitor crítico. Realismo humanitário.

Lia e a sexta série, assim como Miguel e a quinta série, faz parte de uma coleção de quatro obras, nas quais Lino de Albergaria aborda o processo de desenvolvimento fisiológico e psíquico de meninos e meninas que cursam o segundo ciclo do ensino fundamental em uma típica escola de classe média, localizada em alguma de cidade grande brasileira.

No conjunto, o leitor acompanha conflitos individuais e acontecimentos coletivos, a partir da focalização do narrador protagonista (homodiegético), diferente

${ }^{328}$ Márika e a sétima série, p. 92. 
em cada livro. Como numa espécie de Comédia humana para jovens, Lino de Albergaria, a exemplo do que faz Honoré de Balzac, cria personagens principais que transitam entre as quatro histórias em posições diferenciadas com relação ao foco narrativo principal.

De modo geral, os jovens representados pertencem a famílias com relativo poder aquisitivo, já que se locomovem de carro entre a casa e a escola, levados pelos pais, possuem computador pessoal, podem freqüentar shopping centers, consumir produtos da moda e viajar nas férias. De uma série para outra, notam-se problemas e modos de encaminhamento de soluções característicos de cada fase evolutiva, a partir da puberdade.

Blos $^{329}$ emprega a palavra puberdade para indicar as manifestações físicas da maturação sexual. Já o termo adolescência é utilizado para indicar os processos psicológicos de adaptação à condição de pubescência. Em seus estudos, o psicanalista formulou cinco fases do processo de adolescência: pré-adolescência; adolescência inicial; adolescência propriamente dita; final da adolescência, e pósadolescência. Referentemente à vida escolar, as três primeiras delas correspondem ao período que vai da quinta a oitava série.

$\mathrm{Na}$ sexta série, é Lia quem conduz o enredo, a partir das questões que vivencia interiormente e da visão do todo em sua volta: os colegas de classe, o cotidiano da escola, o contexto familiar. Uma das maiores dificuldades da garota está no relacionamento com os rapazes. "Na verdade, o Renato é um menino, um cara, e eu não sei ser amiga de homens" ${ }^{330}$, ela confessa. Sob esse aspecto, difere em muito da irmã, com quem disputa inclusive a atenção do pai. "Às vezes acho que perdi o papai de vez para Raquel. Desde pequenininha, ela avançou sobre ele" ${ }^{331}$, lamenta.

Tendo em vista a origem do problema, é fácil concluir que a competição com Raquel pudesse ultrapassar os limites do lar. De natureza esportiva, exuberante e extrovertida, a irmã, embora mais nova, irá conquistar e namorar o único garoto por quem, até então, Lia havia se interessado. Em decorrência do fato, dá para se imaginar as situações que irão surgir e as provações e sofrimentos pelos quais a garota terá de passar.

${ }^{329}$ BLOS, Peter. Adolescência: uma interpretação psicanalítica. 2.ed., São Paulo, Martins Fontes, 1998, pp. 1-6.

${ }^{330}$ Lia e a sexta série, p. 22.

${ }^{331}$ Ibidem, p. 22. 
Uma das formas de defesa emocional características da faixa etária em que se encontra a personagem principal é o estreitamento das relações de amizade entre indivíduos do mesmo sexo. Explica Blos ${ }^{332}$ :

Passemos agora à menina na adolescência inicial. [...] Sem dúvida a amizade tem um papel igualmente importante na sua vida. A falta de uma amiga pode levá-la ao desespero, a perda de uma amiga pode provocar uma depressão e a perda total de interesse pela vida.

Isso explica a tristeza que Lia sentiu ao romper com Roberta, depois de uma discussão. A melhor a amiga, aquela com quem trocava confidências e compartilhava opiniões sobre o comportamento dos demais alunos, estava "ficando" com Luís Antonio, que as duas consideravam o mais cafajeste da turma. Ainda por cima, Ronaldo, muito amigo do rapaz, havia tentado agarrar Lia. Tantas decepções só poderiam resultar em abatimento, baixa resistência, gripe e até devaneios sobre a morte.

Mas a sorte não deixaria a garota na mão. Outra aluna da sala, Lídia, a "riquinha convencida" ${ }^{333}$, a que vinha para a escola com brincos e relógio de ouro, a que muitos consideravam pedante e esnobe, demonstrou-se mais sensível e companheira do que se podia esperar. É ela quem vai ajudar em muito na recuperação da auto-estima da protagonista, mesmo sem saber dos sentimentos da colega.

Com o moral re-elevado Lia enfrenta os desafios do crescimento. Convive bem com o namoro de Raquel e Renato, até que o destino se encarrega de transformar as relações e tornar amigas as duas irmãs.

\subsubsection{Miguel e a quinta série. Ilustrações de Marco Aragão. 2. ed., São Paulo, Saraiva, 2003. 72 p.}

(C) 2002 - Leitor crítico. Realismo humanitário.

Miguel está saindo da puberdade e entrando na adolescência. Coincidentemente, terminou o ciclo básico do ensino fundamental e agora deve

\footnotetext{
${ }^{332}$ BLOS, Peter. Adolescência: uma interpretação psicanalítica. 2.ed., São Paulo, Martins Fontes, 1998, p.111.

${ }^{333}$ Lia e a sexta série, p. 6.
} 
ingressar na quinta série, o que para ele parece ser um tormento. Primeiro, porque teria de trocar de escola, fato por si só desestabilizador. Segundo, dada a natureza do garoto, avesso a inovações e completamente inseguro com relação ao próprio crescimento. Novo espaço físico, novo sistema de ensino, novos colegas, novos professores, são muitas as mudanças a serem enfrentadas pelo narradorpersonagem, como se nota em seu desabafo:

[...] Queria mesmo é voltar para o ano passado, voltar para a quarta série, para as minhas aulas à tarde...

[...] Quando comprou o uniforme novo, minha mãe notou que cresci. Eu mesmo tive de perceber. [...] Droga, eu não estou querendo crescer tanto! Por que meu corpo não continua igual? Por que o tempo tem de passar tão depressa? ${ }^{334}$

Tantas resistências tinham algumas explicações. Significativas perdas para uma criança prendiam, inconscientemente, Miguel ao passado: a morte da avó materna e a transferência do pai para outra cidade, depois da separação. Esse apego, entre outras formas, manifestava-se pela atração que sentia por fotos antigas da família, a ponto de querer montar um álbum. Ao olhar para os retratos, gostava de reconhecer a herança genética das pessoas: a mãe era parecida com o avô materno; o pai, parecido com o avô paterno; ele, parecido um pouco com o pai e muito com a avó materna. Mesmo sem saber, o que o menino buscava era reconhecer a identificação anímica entre aqueles parentes.

A inconsciência dos processos psíquicos é representada, na narrativa, pelos objetos de estimação. Um globo terrestre e um navio dentro de uma garrafa simbolizavam, respectivamente, o desejo de explorar o mundo e o receio de conhecê-lo, de fato. "Podia girá-lo, brincar com o mundo, saltar da África do Sul para o México, embora nunca pudesse tirar meu navio de dentro da garrafa. [...] Talvez eu fosse como aquele navio. Preso dentro de um vidro" ${ }^{335}$, Miguel lamentava.

No entanto, apesar do medo e das dificuldades, havia dentro do menino força suficiente para impulsioná-lo rumo ao desconhecido. A capacidade de observação era uma das armas de que dispunha ante as circunstâncias da vida, às vezes generosas, às vezes engraçadas, às vezes hostis, que enxergava em seu redor.

\footnotetext{
${ }_{334}^{334}$ Miguel e a quinta série, p. 3.

${ }^{335}$ Ibidem, p. 9.
} 
Dessa maneira, percebe as diferentes formas de expressão de cada professor e a diversidade de comportamento entre os colegas de classe. Como exemplos, o modo espevitado de Patrícia, o jeito tímido e infantil de Leonardo, a beleza bem brasileira de Tatiana, a arrogância de Luis Antonio, a falta de personalidade de Ronaldo, o companheirismo de Renato.

Determinação também não faltou a Miguel no enfrentamento do próprio ciúme, ao saber que a mãe estava namorando, e na hora de encarar um ônibus superlotado para visitar Margarida, a faxineira da escola, num distante bairro da periferia. Lá, sem o menor preconceito de menino classe média, descobre as "delicadezas" da vida humilde, o sabor da comida simples, a alegria de empinar pipa e jogar futebol.

É assim, de pequenos e sutis fatos do cotidiano, que se compõe a narrativa de Miguel e a quinta série, no qual são abordados os conflitos masculinos da préadolescência, fase em que meninos e meninas apresentam padrões de desenvolvimento bem diferentes. Relata Blos ${ }^{336}$ :

O menino pré-adolescente enfrenta a ansiedade de castração (medo e desejo) com relação à mãe arcaica e, assim sendo, afasta-se do sexo oposto; a menina, por outro lado, defende-se contra a pressão regressiva da mãe pré-edípica voltando-se, de maneira vigorosa e decidida, para a heterossexualidade.

No caso específico dos garotos, o psicanalista esclarece que a "fase típica da pré-adolescência masculina, antes de uma passagem bem-sucedida para a masculinidade, recebe sua qualidade característica do emprego da defesa homossexual contra a angústia da castração" ${ }^{337}$. Isso explica a amizade íntima, e de certo modo projetiva, que Miguel estabelece com Renato, única personagem com quem o garoto irá se encontrar nas férias, conforme se fica sabendo no final do livro.

De modo geral, pode-se dizer que na pré-adolescência os obstáculos a serem superados são os sentimentos de raiva, ciúme, rivalidade e, acima de tudo, de impotência e desamparo, e a agressão destrutiva que acompanha essas

${ }^{336}$ BLOS, Peter. Adolescência: uma interpretação psicanalítica. 2.ed., São Paulo, Martins Fontes, 1998, p.90.

${ }^{337}$ Idem, ibidem, p.89. 
experiências. A história e Miguel é o caso particular da luta de um menino que derruba barreiras em direção ao crescimento físico e psicológico.

Miguel e a quinta série é parte de um conjunto de quatro livros (Lia a sexta série, Márika e a sétima série, Chico, Edu e a oitava série) em que Lino de Albergaria aborda as transformações por quais passam os adolescentes durante o segundo ciclo do ensino fundamental. A maioria das personagens transita entre as histórias, em posições narrativas diferentes a partir da focalização adotada.

\subsubsection{Adeus, escola. Ilustrações de Rogério Soud. São Paulo, Saraiva, 1999. $96 \mathrm{p}$.}

\section{(C) 1999 - Leitor crítico. Realismo humanitário.}

Os ritos de passagem presentes em diversos tipos de organizações sociais, fartamente descritos por antropólogos e sociólogos, demonstram claramente a ocorrência de significativas mudanças fisiológicas e comportamentais dos indivíduos durante a puberdade. Por meio de cerimônias específicas, algumas sociedades estabelecem um marco iniciático inequívoco e apresentam modelos pelos quais os jovens podem se guiar, no desenvolvimento de atitudes e traços de caráter. Ensina Blos $^{338}$ :

A designação de um papel e um status novos oferece ao adolescente uma auto-imagem que é definida, recíproca, e vinculada ao grupo; e ao mesmo tempo é promovida a assimilação social da criança em maturação. Sem esse tipo de complementação ou reforço ambiental, a auto-imagem do adolescente perde clareza e coesão.

Institucionalmente, na cultura ocidental não há concordância a respeito das idades em que se deixa respectivamente de ser criança e adolescente. A não existência de linhas demarcatórias claras e precisas para o estabelecimento de direitos, obrigações e responsabilidades impõe à juventude a tarefa de criar formas sociais peculiares e padrões próprios de experiência. Como conseqüência inevitável dessa realidade é que se observam as dificuldades e os conflitos existenciais inerentes a determinadas faixas etárias.

${ }^{338}$ BLOS, Peter. Adolescência: uma interpretação psicanalítica. 2.ed., São Paulo, Martins Fontes, 1998, p. 16. 
Acredita-se, entretanto, que os festejos tradicionais de formatura da oitava série do ensino fundamental venham preencher, de certo modo, esse vazio institucional, pela oportunidade que oferecem de passar em revista os quatro anos anteriores da vida dos alunos, durante os quais vivenciaram intensamente a fase de transição da pré-adolescência para a adolescência inicial. É exatamente isso o que ocorre no enredo de Adeus, escola. A partir do foco privilegiado de Murilo, o narrador onisciente conduz o leitor pelo processo de busca por orientação e discernimento de um grupo de adolescentes, ou melhor, dois grupos, já que, até um determinado estágio de evolução psicológica, a fronteira entre meninos e meninas é francamente vigiada.

Para atingir seus objetivos discursivos, o autor cria uma estrutura narrativa em que se alternam os tempos presente e passado. Assim, simultaneamente às solenidades de formatura, são narrados em flash back fatos do cotidiano escolar, desde a quinta série, que revelam as características e os envolvimentos de cada personagem. Acompanha-se dessa maneira o processo de constituição da turma dos rapazes em oposição à turma das garotas; os sentimentos de solidariedade e socialização de culpa entre os componentes dos grupos; o modo individual e coletivo de atuação frente às inevitáveis circunstâncias competitivas; as cobranças e os ressentimentos decorrentes do fenômeno de idealização do amigo; as ameaças internas e externas à estabilização dos mecanismos de defesa contra a inexorabilidade do crescimento; as ansiedades geradas pelo desejo sexual, e, sobretudo, a reflexão que os próprios adolescentes elaboram sobre os medos e inseguranças que lhes causam o novo e o desconhecido.

Ao lembrar-se do terno preto, comprado especialmente para ir ao baile, Murilo pensa:

Por que uma festa, se não tinha o que festejar? Se ele se sentia triste e inseguro diante da vida nova à sua espera depois daquele baile? Então decidiu que tinha mais era que vestir aquele terno preto. Porque se sentia de luto. Pelas coisas que morriam dentro dele.

[...] Ele mesmo não queria estar crescendo. Sofria daquele jeito por causa de uma escola que tinha de acabar na sua vida. Não seria medo de virar adulto? ${ }^{339}$

${ }^{339}$ Adeus, escola, pp. 25-6. 
No conjunto, as situações narradas, ora tristes ora divertidas, retratam um período de formação da personalidade da maioria dos jovens brasileiros, que não dispõem de quase nenhuma norma a respeito do "vir a ser". O vazio da adolescência não institucionalizada da sociedade ocidental impõe aos meninos e às meninas, entre outras, a difícil tarefa de descobrirem sozinhos que o crescimento se dá na afirmação da identidade individual dentro do grupo. O desempenho dessa empreitada será realizado com maior ou menor facilidade, de acordo com a qualidade do apoio oferecido por pais, educadores e, também, pela literatura. Nesse sentido, livros como Adeus, escola podem ajudar.

\subsubsection{Maria Poliana. Ilustrações de Denise Rochael. Belo Horizonte,} Formato, 1997. 72 p.

(c) 1997 - Leitor crítico. Realismo humanitário.

Escrito em 1912, Pollyanna, de Eleanor H. Potter, foi publicado inicialmente em capítulos no jornal Christian Herald, de Boston. Em 1913, já no formato livro, tornou-se best-seller, traduzido para quase todas as línguas. Chegou às telas do cinema pela primeira vez em 1920, após o que ganhou várias refilmagens, inclusive dos estúdios Disney. Pertencente à galeria de personagens da mais pura tradição sentimental, a protagonista desse romance eternizou-se na história da literatura. Com uma visão peculiar da vida e seu famoso "Jogo do Contente", ficou conhecida por várias gerações de jovens leitoras. Na esteira do estrondoso e imediato sucesso, a autora apressou-se em escrever uma continuação. Editado em 1915, Pollyanna Moça, com novas peripécias da heroína órfã, logo causou tanto encantamento quanto a primeira narrativa. No Brasil, os dois volumes, traduzidos por Monteiro Lobato, foram lançados simultaneamente, em 1934, na Coleção Biblioteca das Moças, da Companhia Editora Nacional.

O êxito comercial das obras chamou a atenção de críticos literários de várias partes do mundo. Para alguns, Pollyana fez-se inesquecível por transmitir preciosas lições de coragem, perseverança e bom humor. Descrita como otimista incorrigível, a garota é capaz de encontrar em tudo, até mesmo no sofrimento, um sentido mais belo para a vida. Essas mesmas qualidades, no entanto, renderam-lhe opiniões bastante desfavoráveis. Muitos acreditam que a personagem representa um 
desacreditado exemplo de conformismo, com nefastas conseqüências para a formação da personalidade das crianças e das adolescentes.

Situado entre essas duas correntes, encontra-se o narrador intruso de Maria Poliana, livro no qual Lino de Albergaria estabelece intertextualidade explícita com o trabalho de Eleanor H. Potter. O autor cria uma jovem cujo comportamento é em tudo antagônico ao da personagem americana. Se Pollyana chega a irritar o leitor por ser "contente" em demasia, Maria Poliana inicialmente enerva de tão irascível e mal-humorada que é. Para começo de conversa, detestava o próprio nome, e ai daquele ou daquela que esquecesse de chamar-Ihe Ana: acabava ganhando uma inimiga. Era o caso de Cláudia. Desavisada a respeito do temperamento da garota, a nova professora de Português insistia em dizer o nome completo da aluna. Por meio do recurso enunciativo que combina discurso indireto livre com discurso direto, percebe-se o rancor de Maria Poliana, ou melhor, Ana.

Cláudia. Até que tinha um nome bonito, ou, pelo menos, normal. Mas era uma mulatinha empertigada. Mulatinha, sim. Cabelo ruim, a pele quase marrom. Com o maior jeito de empregada e ali, na frente, na maior pose, ditando regra.

"Essa regra não vai pegar! Ela não vai decretar que eu me chamo Maria Poliana!", Ana jurou, dentro do seu silêncio. ${ }^{340}$

Segue a efabulação, construindo a imagem de uma adolescente egocêntrica, birrenta e racista. Para Ana, quem não concordava com ela estava radicalmente contra ela. Além de Cláudia, eram muitos os que estavam: a professora Luísa, os colegas Rodrigo, Artur, Alicia, Renata, Luana, o pai de Luana e, principalmente a mãe, Zélia, por ter-Ihe dado o nome. Só não "aquele grandalhão lerdo" ${ }^{341}$ do Jonas, que a tratava carinhosamente. Mas esse não contava muito, exceto quando precisava dele para servir de guarda-costas ou provocar Rodrigo, cujos "olhos verdes tinham uma expressão inteligente". ${ }^{342}$

No decorrer da leitura, entretanto, vai-se compreendendo as angústias que marcaram o desenvolvimento psicológico de Ana. Para ela, a separação dos pais devia-se única e exclusivamente à intransigência da mãe, pois Sérgio, o pai, era o

\footnotetext{
340 Maria Poliana, p. 6.

341 Ibidem, p. 17.

${ }^{342}$ Ibidem, p. 12.
} 
melhor homem, o mais bondoso, o mais bem humorado. Sob esse aspecto, a personagem em nada se diferencia da maioria das garotas da mesma idade. "Muitas meninas estão convencidas de que compreendem o pai melhor do que a mãe pode compreendê-lo", esclarece Blos. ${ }^{343}$ Em seu caso, entretanto, a situação agravava-se pela forte decepção que sentia com o conformismo de Zélia, que não trabalhava e assumia o papel de vítima.

Esses problemas, somados às tradicionais dificuldades de auto-afirmação social típicas da adolescência, só faziam pesar ainda mais a baixa auto-estima que o próprio nome lhe causava. Estaria ela condenada a ter um destino de Pollyanna? "A boazinha, a que estava sempre 'contente', com certeza levando porrada e agradecendo"? ${ }^{344}$ Maria Poliana, decididamente, não queria ser assim. Por isso decretara: havia de chamar-se Ana e, para tanto, bolara um plano. Antes que pudesse concluí-lo, porém, acontecimentos inesperados e marcantes agitam a vida da garota e transformam-na interiormente. Dessa forma, modifica-se também o comportamento das pessoas com quem se relaciona e, conseqüentemente, o modo como ela vê o mundo a seu redor.

Com relação ao processo de construção da narrativa, a maneira como o autor cita as obras de Potter é digna de nota. Sucintas sinopses de Pollyanna e Pollyanna Moça são apresentadas tão naturalmente diluídas, que mal se percebe a razão de estarem ali para orientarem o leitor. Assim, mesmo quem não conhece os textos mencionados pode apreender com tranqüilidade os sentidos das relações intertextuais. Já referentemente ao plano ideológico, o narrador posiciona-se de forma a erigir uma opinião intermediária, ou seja, a de que todo o otimismo é salutar até o ponto em que não se transforme numa atitude cega de aceitação, sem questionamentos, de quaisquer regras e valores sociais.

\subsubsection{De Paris, com amor. Ilustrações de Sônia Magalhães. 3. ed., São Paulo, Saraiva, 1997. 88 p. \\ (C) 1997- Leitor crítico. Realismo humanitário.}

Fim do século XX, 1997, o mundo já se comunica por correio eletrônico e salas virtuais de bate-papo. Os programas de mensagens instantâneas, do tipo MSN

\footnotetext{
${ }^{343}$ BLOS, Peter. Adolescência: uma interpretação psicanalítica. 2. ed., São Paulo, Martins Fontes, 1998, p.144.

${ }^{344}$ Maria Poliana, p. 32-3.
} 
e Windows Live, da Microsoft, não demorariam a chegar ao mercado e a se popularizarem via internet. Inicia-se o tempo em que a privacidade e o anonimato no que se refere à troca de correspondência são paradoxalmente possíveis e ilusórios. Nessa época de tecnologia avançada, na qual namoro e sexo virtual são práticas corriqueiras, dois jovens irão protagonizar um delicado romance epistolar, por meio de suportes convencionais, isto é, cartões postais, cartas e bilhetes.

Melissa é romântica. Não está interessada em beleza, nos rapazes que malham em academias de ginástica para terem corpos sarados. Atração mesmo sente é por sensibilidade. Sob esse aspecto, Paulo Sérgio parece ser o tipo ideal: é o melhor aluno em redação e tem um timbre de voz que soa como "pura música" 345. Acontece, porém, que a garota é tímida. Não se comporta com a mesma desenvoltura das adolescentes contemporâneas, embora também não tenha nenhum preconceito com relação ao fato de as mulheres atualmente tomarem a iniciativa nas situações de paquera.

Assim, o jeito que melhor encontrou de abordar o colega de classe foi o de deixar um cartão postal, assinado "A Ignorada", dentro do livro de Matemática do rapaz. A atitude, entretanto, não Ihe pareceu suficiente. Em seguida escreveu uma cartinha, introduzida disfarçadamente no caderno dele. Nessa, solicitava resposta. Paulo Sérgio, de início, imaginou que estivessem de zombaria. De todo modo, resolveu entrar no jogo. Seguindo instruções deixadas pela garota, sobre como enviar a correspondência, respondeu com o pseudônimo de Quasímodo. Naquele momento, nem ele imaginava que uma simples brincadeira com o nome do Corcunda de Notre-Dame pudesse ir tão longe.

Na resposta seguinte, mandou um cartão postal de Paris, no qual se avistava uma ponte sobre o rio Sena. Melissa entendeu essa imagem de maneira simbólica, e argumentou:

Então, acho que você queria me dizer algo quando me enviou a fotografia de uma ponte. E responder meus bilhetes e minhas cartas é bem isso: criar uma ponte entre a gente! ${ }^{346}$

\footnotetext{
${ }^{345}$ De Paris, com amor, p. 25.

${ }^{346}$ Ibidem, p. 13.
} 
Criada a ponte, os dois farão uma verdadeira viagem imaginária pela capital da França. Mapas, guias e fotos servirão de orientação para o fantástico passeio escrito, durante o qual Paulo Sérgio tentará (e conseguirá) descobrir a identidade de Melissa. Entre ruas e monumentos da Cidade Luz, eles irão se aproximar, se conhecer, se apaixonar, até brigar para depois namorarem "na real", timidamente, no banco da praça, ao lado da escola.

Em termos de organização do discurso, é o modo enunciativo que estrutura a narrativa $^{347}$. O processo dialógico constante, em que os conteúdos temáticos são sempre retomados ora por uma ora por outra personagem, garante a progressão da trama. Além disso, o autor de De Paris, com amor cria estilos de escrita feminino e masculino, que revelam ao leitor as características da garota e do rapaz. Sobre esse gênero literário, explana Barbosa ${ }^{348}$.

O romance epistolar se insere entre as formas do gênero que fundamentam seus efeitos de verdade na escritura íntima. Apropriando-se de uma correspondência privada, o autor do romance epistolar não apenas oferece ao público uma escrita particular e que se apresenta como nãofictícia. Ele também se posiciona como alguém que violou uma correspondência e, no momento presente, partilha com o leitor essa correspondência que poderia, se assim o quisesse, conservar como matéria de leitura íntima. Partilhando-a, ele institui o seu público leitor como cúmplice da violação do espaço privado da escrita. A violação a torna legítima e suficiente para justificar a importância dela para si mesmo e para o público.

A "violação" que Lino de Albergaria faz da correspondência entre Paulo Sérgio e Melissa a torna legítima no contexto situacional da obra. Pelo acesso às missivas trocadas entre o casal, o jovem leitor da era cibernética, na posição de voyeur, vivencia uma sensível história de amor, construída como nos tempos em que o computador ainda não existia. E ainda obtém bônus: percorre os principais pontos turísticos de Paris. Num mundo em que o conhecimento circula cada vez

${ }^{347}$ CHARAUDEAU, Patrick. Grammaire du sens et de l'expression. Paris, Hachette, 1992, p. 647.

${ }^{348}$ BARBOSA, Ivanilda. A escrita paterna e o desvelamento de sentido em Uma noite em Curitiba. Estudos de Literatura Brasileira Contemporânea, n.7. Brasília, maio/junho de 2000, pp. 11-21. Cristóvão Tezza. Disponível em: http://www.cristovaotezza.com.br/critica/trabalhos acd/f artigos/a\%20escrita\%20paterna.htm. Acesso em: 10 set. 2006. 
mais por veículos virtuais, o texto pode motivar o estudante a pesquisar em documentos outros que não só os programas de busca da internet.

7.1.11 Uma história de amor. Ilustrações de Avelino Guedes. 2. ed., São Paulo, Moderna, 1995. 80 p.

\title{
(C) 1995 - Leitor crítico. Realismo humanitário.
}

Entre as décadas de 1940 e 1960 tornou-se popular no Brasil uma série de romances, lidos principalmente por mulheres jovens, cujas características fizeram com que fosse rotulada, genericamente, como "literatura cor-de-rosa". Suas histórias, quase sempre ambientadas na França, foram traduzidas e editadas pela Companhia Editora Nacional (SP), para integrar a Coleção Biblioteca das Moças, vendida no país inteiro com o apoio de forte estratégia publicitária. Escrevia esses livros um casal de irmãos franceses que utilizava o pseudônimo M. Delly ${ }^{349}$. Esclarece Cunha ${ }^{350}$ :

\begin{abstract}
Nesses romances narrava-se a trajetória de moças exemplares, da meninice ao casamento, em um clima de encantamento e fantasia, típicos dos contos de fadas, nos quais se assegurava à leitora curiosa o benefício de um final feliz. Sua fórmula de sucesso obedecia a modelos infalíveis, seja lidando com um sentimento caro às mulheres, o amor, seja mostrando um imaginário romântico através de descrições de paisagens exóticas e luxuriantes, personagens jovens, bonitos e ricos, movendo-se em um cenário atingível apenas pela fantasia, pela imaginação.
\end{abstract}

Herdeiras dessa literatura, as coleções Júlia, Sabrina e Bianca, publicadas pela editora Nova Cultural e comercializadas com grande sucesso em bancas de revistas, atualizam para as leitoras contemporâneas essas histórias de amor açucarado. Com enredos adaptados para os tempos atuais, romances idealizados e fantasiosos continuam alimentando o imaginário não só de adolescentes, mas de mulheres de todas as faixas etárias.

${ }^{349}$ Frédéric Henri Petitjean de la Rosiére (Vannes, 1870 - Versailles, 1949) e Jeanne Marie Henriette Petitjean de la Rosiére (Avignon, 1875 - Versailles, 1947).

${ }^{350}$ CUNHA, Maria Teresa Santos. Mulheres e romances: uma intimidade radical. Scielo Brasil, Cadernos CEDES. Campinas, jul. 1998. Disponível em: http://www.scielo.br/scielo.php?pid=S010132621998000200007\&script=sci arttext. Acesso em: 26 ago. 2006. 
Inspirado no gênero e com o objetivo de subvertê-lo, isto é, de torná-lo menos piegas e trazê-lo para mais perto da realidade, Lino de Albergaria escreve Uma história de amor, na qual se faz referência não só à "literatura cor-de-rosa", mas também a renomados autores que abordaram o amor como tema de suas produções. Adélia Prado, Cora Coralina, Fernando Pessoa fazem companhia a um casal de adolescentes durante um feriado prolongado na praia, em que as condições climáticas atuam no sentido de revelar o interior das personagens.

Alex, por exemplo, adorava a chuva e os dias cinzentos. Tipo magro, branquelo, de óculos e cabelos espetados, era triste, introspectivo e tirado a intelectual. Além dos poemas de Pessoa, um livro de História, Nietzsche e Saramago compunham sua bagagem, embora nem tudo que lia o garoto entendesse. Marina, apesar de preferir o sol, trazia a alma dolorida pelo fato de Fausto ter escolhido Estela para namorar. Mais do que ser preterida pelo rapaz, sentia a perda da única amiga. Na ausência de um sentimento verdadeiro, é na "biblioteca das moças" que vai buscar lenitivo para o vazio de seu coração.

[...] Seus dedos tatearam entre lençóis e toalhas. Num instante retiraram o livro.

Voltou para a cama. Esqueceu chuva ou choro. Ali dentro tinha amigos e emoções. Personagens eram gente, com suas vidas interessantes, caminhando como se habitassem os sonhos. Histórias eram palavras que criavam um ninho, um ninho que a recebia e a envolvia. Onde podia entrar e ficar. Encontrar o calor e o carinho de um acalanto. Podia até chorar. Ou rir. Mas nunca de si mesma. ${ }^{351}$

A atitude da garota com relação a esse tipo de literatura é representativa a da maioria das leitoras que fazem o êxito de vendas das coleções da Nova Cultural e que, por vezes, causam espécie em homens e rapazes pouco afeitos à expressão melosa dos sentimentos. Embora um tanto quanto seduzido pelo jeito despojado e pouco vaidoso de Marina, que rói unhas e usa cabelo curto, Alex não deixa de se decepcionar com o gosto literário da menina.

Mas como atração e desejo não se prendem a esses detalhes, segue o enredo revestindo a estrutura narrativa clássica das histórias de amor, em que não faltam encontros e desencontros, aproximações e afastamentos, intrigas e soluções

${ }^{351}$ Uma história de amor, p. 9. 
protagonizadas pelo destino (prenunciado pelo tarô e pela astrologia), até que chegue o tão esperado final feliz.

As diferenças entre Uma história de amor e qualquer romance-novela da chamada "literatura cor-de-rosa" são várias. Destacam-se, por exemplo, referências bíblicas e a obras clássicas da filosofia, da poética e da pintura. Dessemelhante também é o cenário: praia cinza e chuvosa, ou ensolarada, mas nem um pouco romântica, dada a quantidade de turistas ruidosos; antagônico, portanto, aos normalmente inatingíveis daquele gênero. Como concessão à fantasia, surge uma canoa encalhada na areia, apodrecida, que estabelece o elo entre o real e o idílico, criado por meio de imagens em que o mar se conjuga com amar, no dizer dos poetas intertextualizados. Outras divergências relacionadas com a "coleção das moças" encontram-se na trama totalmente realista, comum ao cotidiano de qualquer jovem da atualidade, e na presença de personagens em nada extraordinárias ao lidarem com seus preconceitos, receios, inseguranças e esquisitices.

Se há algo de "heróico" em Alex e Marina, pode-se dizer que é a disposição de ambos para amadurecerem e abrirem-se às influências um do outro: ele, no sentido de inferir que romantismo água-com-açúcar faz parte da vida de qualquer garota adolescente; ela, pela capacidade de compreender que há formas estética e artisticamente mais sensíveis e inteligentes de expressar o amor.

Referentemente ao plano formal da obra, vale destacar a focalização narrativa como aspecto discursivo importante para a construção da interioridade das personagens e da simultaneidade temporal das ações. O narrador heterodiegético onisciente revela para o leitor, alternadamente, o ponto de vista da garota e do rapaz a respeito das mesmas ações. Há, inclusive, um capítulo quase que integralmente narrado duas vezes a partir da perspectiva de cada um.

\subsubsection{Caderno de segredos. Ilustrações de Jayme Leão. 7. ed., São Paulo, Saraiva, 2002. 72 p. \\ (C) 1995 - Leitor crítico. Realismo histórico, crítico e humanitário.}

As possibilidades de leitura oferecidas por Caderno de segredos são tão variadas, que se torna difícil escolher por qual delas começar a abordar a obra. A primeira que salta à vista, no entanto, é a de que o livro retrata a vida na periferia, a partir da perspectiva de um jovem morador de favela. Nesse sentido, por ser uma 
visão de dentro, difere dos relatos normalmente estereotipados com que os meios de comunicação de massa representam as relações humanas no interior das comunidades carentes.

Por meio do acesso ao diário íntimo de José Carlos, o leitor percebe que nem só de tráfico de drogas, furtos ou outros crimes se alimentam as esperanças dos milhões de adolescentes que vivem em barracos pendurados nas encostas dos morros que circundam a maioria das cidades brasileiras. Segundo Blos ${ }^{352}$, a manutenção de um diário, independentemente do conteúdo manifesto, relacionado com classe social, região geográfica e época histórica, é prática típica de um período do desenvolvimento psicológico em que a fantasia surge como fenômeno transitório entre as fases de narcisismo e de procura objetal heterossexual. A afirmação do psicanalista confirma-se nas circunstâncias da personagem em questão. Leia-se um trecho do que o garoto escreve:

[...] Tenho certeza de que, aos poucos, vou contando nele [no diário] tudo que for importante. Minhas vontades, meus pensamentos e também meus sofrimentos. Não que eu viva sofrendo. Pelo menos não por doença, que não tenho nenhuma, graças a Deus. Ou por ficar querendo aquilo que não é meu. $\mathrm{Ou}$ ficar sonhando alto demais. Sofro mais é por amor. Acho que me apaixono muito é à toa. $E$ as meninas não se ligam em mim. ${ }^{353}$

O diário é mais comum entre as meninas do que entre os meninos. José Carlos sabe disso bastante bem. "Não me importo que digam que escrever diário é coisa de menina. Eu tenho vontade e isto é o mais importante" ${ }^{354}$, é o que ele diz. Blos $^{355}$ constata:

[...] A auto-absorção emocional implícita na manutenção de um diário adquire facilmente para o menino uma conotação de passividade; sua necessidade de afirmação física extroversiva, com freqüência defensiva, muitas vezes afasta a sua atenção da introspecção.

${ }^{352}$ BLOS, Peter. Adolescência: uma interpretação psicanalítica. 2.ed., São Paulo, Martins Fontes, 1998, pp. 127-8.

${ }^{353}$ Caderno de segredos, p. 8.

${ }^{354}$ Ibidem, p. 7.

${ }^{355}$ BLOS, Peter. Adolescência: uma interpretação psicanalítica. 2.ed., São Paulo, Martins Fontes, 1998, pp. 127-8. 
No caso de José Carlos, não se pode dizer que introspecção signifique passividade. Nota-se apenas que "sua necessidade de afirmação física extroversiva" é menor do que a de outros rapazes. Se para ele o diário é um instrumento por meio do qual conversa consigo próprio, o poema é o gênero de que se utiliza para expressar o modo de entender a vida. "Minha cabeça não foi feita para fazer gol. Minha cabeça é uma máquina de ficar pensando" ${ }^{356}$, confessa o garoto, quando se compara com o amigo Marílton, cujo maior desejo é tornar-se craque de futebol.

Outra leitura intrínseca a Caderno de segredos relaciona-se com a História do Brasil. Além de conflitos adolescentes, acompanham-se pela escrita de José Carlos fatos que marcaram a sociedade brasileira de agosto de 1994 a janeiro de 1995 . Está representada, por exemplo, a conquista do tetracampeonato de futebol na Copa do Mundo de Atlanta, nos Estados Unidos, na qual brilhou como líder absoluto o artilheiro Romário, espécie de mito para o rapaz. "Eu sou ruim de bola, mas tenho algo a ver com o Romário [...] sou do morro, como ele. E, como o Romário, não tenho vergonha de dizer de onde eu sou." 357 Ayrton Senna, que morrera no dia primeiro de maio, em acidente no Grande Prêmio de San Marino, também é lembrado.

Mas, sobretudo, são os acontecimentos políticos que constituem o pano de fundo sobre o qual se registram as expectativas dos jovens em meados dos anos 1990. Depois de quase três décadas de inflação elevada, um plano de estabilização econômica atinge plenamente os objetivos, sem congelamento de preços, confisco de depósitos bancários ou outras disposições artificiais, e resulta na substituição da antiga moeda pelo Real, a partir de primeiro de julho de 1994. O país abre-se irreversivelmente à globalização. Para a população de todas as camadas sociais, as medidas repercutiram no incremento do consumo. A classe média passa a desfrutar de produtos importados, como os automóveis citados no diário de José Carlos. "Era um carro importado, coreano, como me explicou o Etevaldo. Esses carros começaram a aparecer no clube e eu ainda não me acostumei com as marcas" 358 . Os moradores de áreas invadidas alimentam-se melhor e conseguem ampliar ou reformar suas casas. Nunca havia se vendido tanto material de construção para esse segmento como naquela época. José Carlos, lavando carros no

${ }^{356}$ Caderno de segredos, p. 9.

357 Ibidem, p. 5.

${ }^{358}$ Ibidem, p. 14. 
estacionamento do clube, e sua madrasta Rosa, trabalhando como faxineira, obtêm o dinheiro para rebocar e pintar o barraco em que vivem.

Talvez, nunca antes, também, os habitantes das favelas tenham sonhado tanto em fazer parte da "sociedade do espetáculo", a exemplo do que ocorria com Maria Laura. A garota, por quem José Carlos se apaixona, tem uma aspiração quase obsessiva: tornar-se modelo e atriz de telenovela. "O espetáculo não é um conjunto de imagens, mas uma relação social entre pessoas, mediada por imagens", afirma Debord $^{359}$. Jappe ${ }^{360}$, ao comentar o pensamento de Debord, esclarece que o fenômeno de que trata o autor vai muito além do que a onipresença dos meios de comunicação de massa na vida das pessoas.

[...] o espetáculo é uma forma de sociedade em que a vida real é pobre e fragmentária, e os indivíduos são obrigados a contemplar e a consumir passivamente as imagens de tudo o que Ihes falta em sua existência real.

Têm de olhar para outros (estrelas, homens políticos etc.) que vivem em seu lugar. A realidade torna-se uma imagem, e as imagens tornam-se realidade; a unidade que falta à vida recupera-se no plano da imagem. Enquanto a primeira fase do domínio da economia sobre a vida caracterizava-se pela notória degradação do ser em ter, no espetáculo chegou-se ao reinado soberano do aparecer. ${ }^{361}$

Pelo que se depreende do texto, a maioria das personagens que figuram no diário do adolescente não só consomem passivamente as imagens do que lhes falta na vida real, como também almejam a visibilidade. Querem por toda sorte inserir-se na realidade imagética, construída especialmente pelo poder da televisão, que faz do Brasil o país do carnaval, do futebol e da telenovela. Em Caderno de segredos, o único que parece questionar tal realidade é o próprio José Carlos. Quando os vizinhos insistem que seus poemas devem se tornar letra de samba, pergunta o rapaz:

${ }^{359}$ DEBORD, Guy. A sociedade do espetáculo. Pausa para a Filosofia. Disponível em: http://br.geocities.com/mcrost12/a sociedade do espetaculo 1.htm. Acesso em: 20 ago. 2006.

360 JAPPE, Anselm. A arte de desmascarar. A sociedade do espetáculo: um dos principais libelos contra o capitalismo. Pausa para a Filosofia. Disponível em: http://br.geocities.com/mcrost12/a sociedade do espetaculo 0.htm. Acesso em: 20 ago. 2006.

361 Idem, ibidem. 
Sucesso, sucesso! Por que é que as pessoas sonham com isso? O Marílton com a camisa da seleção, Maria Laura com uma tela de televisão. [...] Se é que eu tenho um dom, tenho de transformar em ambição? ${ }^{362}$

No que se refere à linguagem, um crítico mais ortodoxo poderia questionar o fato de José Carlos, garoto morador de favela, empregar o padrão culto da língua ao escrever seu diário. Acredita-se, no entanto, que o contexto paradidático no qual se insere o livro em questão, por si só, justifica o uso dessa variante lingüística. Além do mais, a opção do autor por essa modalidade garante a ausência no texto de preconceitos e estigmas, que facilmente poderiam incorrer ao se tentar reproduzir os linguajares típicos da periferia. Isso, sem falar da característica efêmera da maioria das construções lingüísticas populares, cuja presença no texto tornaria a obra datada.

\subsubsection{Pio e Pinóquio. Ilustrações de Nélson Cruz. 4. ed., Belo Horizonte, Lê, 1996. 96 p. \\ (c) 1993 - Leitor crítico. Realismo humanitário.}

Quem inventou o guaraná? Ou melhor, quem descobriu que aquela frutinha da Amazônia poderia servir para fazer refrigerante? Pio tem uma versão para responder a essa pergunta, e vai utilizá-la com o objetivo de conquistar Ludmila, sua colega de classe na escola. A lenda do amor entre um velho cientista e Lua de Milho, a índia cuja alma (ou seria o nome?) havia sido enfeitiçada pelo próprio pai, o pajé, vai sendo contada aos poucos, sempre interrompida, estrategicamente ou por artimanhas do acaso, de modo a manter aguçada a curiosidade da garota. "Que durasse pelo menos mil e uma noites. Ou mil e um intervalos. O tempo que fosse, para conquistar Ludmila" ${ }^{363}$, enuncia o narrador no estilo indireto livre, em alusão aos contos orientais de As mil uma noites.

Além de experimentar as transformações físicas naturais por que passam os adolescentes, e que, em geral, causam conflitos e angústias no processo de construção de uma nova auto-imagem, Pio é obrigado a lidar com as diferenças culturais entre a vida na roça e na cidade grande e, ainda, com as marcas existenciais de um passado que ele luta para esquecer, mas que a todo instante

\footnotetext{
${ }^{362}$ Caderno de segredos, p. 49.
}

${ }^{363}$ Pio e Pinóquio, p. 18. 
ameaça irromper no presente. Filho de pais matutos, o garoto, já com certa idade, havia sido dado em adoção para o tio Gesualdo e a tia Hortência, de hábitos urbanos.

A herança da origem se fazia evidente na fala, isto é, na variante lingüística típica do caipira brasileiro, e também no comportamento. Quando menino, Pio não andava, corria e pulava. Mexia-se tanto e fazia tanto barulho, que o novo pai o chamava de "macaquinho". Com a chegada da puberdade e, com ela, da consciência sobre as diferenças sociais, o então rapaz vê-se forçado a buscar outro modo de vida, escolhido e feito por ele mesmo. A mudança de escola era o pretexto de que precisava para enfrentar tal tarefa. Mas motivação maior mesmo obteve ao se apaixonar por Ludmila.

Os maiores problemas de Pio, no entanto, estavam apenas começando: o físico magro, franzino, desproporcionalmente desenvolvido; o nariz um pouco avantajado, cuja ponta uma acne insistente vinha sempre macular; o tom de voz indefinido, deixando escapar desafinados, inadvertidos e vexatórios falsetes em meio a um registro mais grave. Tudo isso fazia as infelicidades e inseguranças desse rapaz, que costumava guardar fotos antigas e anotações num livro sobre insetos, coincidente e significativamente, entre as páginas dedicadas ao estudo dos grilos.

Como não podia deixar de ser, sentimentos de confusão e solidão criam em Pio a necessidade de buscar no mundo externo as referências de que precisava. Com o amigo Gedeão, encontra na turma o ambiente propício para dar livre expressão aos impulsos de rebeldia e resistência aos valores impostos pelos adultos. Por meio do cinema, especialmente pelo filme Cyrano de Bergerac, personagem com quem se identifica, conhece o poder sagaz da mentira, que utiliza como forma de apagar lembranças indesejadas e de construir as bases de um futuro idealizado. Na academia de ginástica, atenta contra a própria natureza, na esperança de obter um corpo forte e musculoso. Nada disso, entretanto, é suficiente para atenuar a ansiedade provocada pela maturação das funções sexuais e aliviar a culpa por considerar-se ingrato, em razão de determinadas circunstâncias, ao pai adotivo.

O único conforto para aquele espírito atormentado vem da tia Hortência, a quem desde cedo Pio havia se acostumado a chamar de mãe. É a partir dessa "fada-madrinha" de olhos azuis que irão se formar na mente do rapaz as 
representações do amor feminino, extremamente importantes para a manutenção de seu equilíbrio emocional. Tanto é que ele nunca se sentira tão sozinho quanto da vez em que ela, nervosa por causa do comportamento do filho de criação, havia se recusado a beijá-lo. Ainda mais porque isso havia ocorrido logo depois de ter sido pego na mentira e abandonado pela garota por quem se apaixonara.

Nesse momento, só mesmo uma volta ao passado, um reencontro com as próprias origens, o resgate das situações conflitantes decorrentes da relação com a figura paterna internalizada, que no caso de Pio era extremamente complexa, poderia abrir brechas para a solução dos impasses psicológicos do adolescente. Sob esse aspecto é que a trama narrativa de Pio e Pinóquio, apropriadamente, se intertextualiza com a famosa obra do italiano Carlo Collodi. De acordo com a visão psicanalítica, a primeira infância e a puberdade apresentam modelos de desenvolvimento similares, em que as organizações mentais se formam em associação com funções fisiológicas ${ }^{364}$. Dessa forma, encontram-se justificadas as inúmeras referências ao boneco de madeira cujo sonho era tornar-se menino. $O$ sonho de Pio é encontrar o caminho para a maturidade.

\subsubsection{Em busca do novo rei: um jogo literário. Ilustrações de Regina} Rennó. São Paulo, Atual, 1993. 80 p.

\section{(C) 1993 - Leitor crítico. Maravilhoso metafórico}

Já no subtítulo, Em busca do novo rei aponta para a natureza metaliterária desta narrativa em cuja seqüência e em cujos desdobramentos o leitor pode interferir, conforme as diversas alternativas oferecidas pelo narrador. Nesse contexto de "história desmontável", como se apresenta no prefácio, o ato de narrar é por diversas vezes explicitado em trechos metalingüísticos que deflagram o processo de construção literária. Por meio do mesmo procedimento, são instaurados no texto alguns tipos de leitor, com graus diversos de interesse e competência de leitura. Assim, a obra pode ser lida de forma breve, em versão com apenas dois capítulos; de maneira linear, isto é, integralmente, ou sob a ótica de cada uma das três personagens principais. De acordo com a perspectiva escolhida, haverá um final diferente e, para as curiosidades mais aguçadas, algumas surpresas.

${ }^{364}$ BLOS, Peter. Adolescência: uma interpretação psicanalítica. 2.ed., São Paulo, Martins Fontes, 1998, p. 7. 
O enredo em comum a todas as versões é a procura por um herdeiro para o trono de Esteranoases. Durante muito tempo o reino vivera na mais completa felicidade. A paz e a alegria eram tantas que o rei nem se preocupou com o fato de sua esposa ser estéril. Mas, com a morte súbita da rainha, estranhos presságios começam a pairar sobre a vida naquelas terras. O sol deixou de brilhar e as nuvens estacionaram sob o céu de Téfer, a capital. Os pássaros migraram, os jardins começaram a estiolar. O mago da corte, ao consultar seus oráculos, via "sombras crescendo, insinuando em torno do país uma longa cortina de trevas ${ }^{365 " .}$ Preocupado em encontrar um sucessor, Égon, o rei, encerra-se na estufa de plantas, para pensar. É quando os espinhos de uma muda de árvore, transplantada de uma das mais remotas fronteiras do país, fere a pele de seu peito, fazendo escorrer três gotas de sangue. Imediatamente, de modo extraordinário, as três gotas alçam vôo e somem no ar. O camareiro do palácio é a única pessoa a testemunhar o fato. No mesmo instante faz menção a uma lenda sobre três gotas mágicas que salvariam o reino de um grande perigo, mas cujo conteúdo completo ele não conseguia se lembrar.

Suspense construído, a história irá se desenrolar de acordo com a opção do leitor. De modo geral, no entanto, podem ser destacadas da narrativa de todos os percursos algumas características inerentes ao conto maravilhoso, como a saga do herói, a utilização da magia e de instrumentos de poder, animais que pensam e falam, o arquétipo do velho sábio, a presença de bruxas e fadas, o combate entre o bem e o mal. Elementos simbólicos também contribuem para o estabelecimento de relações semânticas entre os episódios. É o caso, por exemplo, do número três. São três gotas de sangue, são três as personagens principais, Marlos, Simara e Tambo, são três os objetos mágicos presentes em mais de uma situação, são 21 noites (número cuja soma é três) de trabalho na tentativa de salvar o reino de um ataque inimigo, são três lágrimas reais que Égon imagina poder derramar sobre a muda de árvore que ferira seu peito.

Do ponto de vista argumentativo, algumas proposições emergem reiteradamente no nível discursivo. Entre essas, ressaltam-se: a inexorabilidade do destino, que nos diferentes enredos se cumpre independentemente da vontade ou ação dos seres; a importância da tradição oral popular, não só para a preservação

${ }^{365}$ Em busca do novo rei, p. 2. 
da cultura, como também para a manutenção da identidade e soberania de um povo; a dissimulação e o fingimento como estratégia legítima de autodefesa dos mais fracos; a valorização da sabedoria dos idosos, e a atenção que se deve prestar ao conhecimento enigmático dos loucos, aflorado por meio do contato estreito com o inconsciente. Contato esse que os considerados não-loucos estabelecem por meio do sonho. A utilização do sonho, aliás, como veículo de comunicação e de tomada de consciência, é característica intrínseca às personagens principais e, na voz intrusa do narrador, condição essencial para a lucidez dos seres humanos:

Quem ignora o coração e os sonhos, apenas enxerga a realidade (que consiste numa visão reduzida) e não pode dar mais que alguns centavos pelo futuro de nosso mundo. ${ }^{366}$

Ultrapassar essa visão reduzida é a tarefa proposta especialmente para o leitor que opta pela "via longa", ou seja, pela leitura integral e linear da obra, com a disposição de estar sempre atento aos significados metafóricos que subjazem à linguagem culta e densa por meio da qual se constrói a narrativa.

\subsubsection{Alice no metrô. Ilustrações de Marilda Castanha. 4. ed., Belo} Horizonte, Lê, 1997.80 p.

\section{(C) 1993 - Leitor crítico. Realismo humanitário}

Alice mora em São Paulo, e todo dia vai à escola de metrô. Apesar de espremida em meio à multidão, nas escadas rolantes, nas plataformas e nos vagões dos trens, a garota mantém seu ritmo, comandado mais pelo devaneio dos pensamentos do que pela agitação da cidade grande.

No mundo da imaginação, Alice havia criado Tersie Tolly, espécie de alter ego, ou melhor, de figura multifacetária, representativa das várias personalidades em desenvolvimento no estágio de transição psicológica, característico do início da adolescência. Sempre com o mesmo nome, Tersie Tolly multiplica-se por sete personagens: atriz de cinema, escritora de livros policiais, espiã internacional, domadora de tigres, visitante interplanetária, anjo em missão na Terra, treinadora de pássaros. Cada uma, ou às vezes mais de uma, surgindo de repente na mente de 
Alice, dialogando com a adolescente e influenciando suas atitudes, de acordo com as circunstâncias.

Mesmo com tanto vozerio interior, Alice não deixava de reparar em alguns tipos que Ihe chamavam a atenção. Foi assim que, certa vez, notou "um menino engraçado, com dentes de coelho" ${ }^{367}$ que passou correndo por ela. Estava criado mais um motivo para que Tersie Tolly se manifestasse. Nesse dia, a escritora e a agente secreta disputavam a supremacia na mente da garota. Quem seria aquele sujeito? Por que estaria tão apressado? As respostas talvez rendessem boa história. "As três" resolvem segui-lo.

Ao percorrer esse fio condutor por um caminho com muitas surpresas, o leitor fica conhecendo melhor quem é Alice, que conflitos enfrenta para tornar-se mocinha. Alterações na relação com a mãe, sentimentos divididos entre os privilégios da infância e a antevisão dos deveres da vida adulta, dificuldades em abandonar os hábitos quase masculinos de menina ativa, busca por uma identidade diferenciada com relação a suas amigas, necessidade de acomodar as pulsões referentes ao complexo de Édipo, que retorna nessa fase, são apenas algumas das questões com as quais lida a protagonista.

Como se sabe, a adolescência é o momento na vida do indivíduo em que mudanças anatômicas e fisiológicas ocorrem paralelamente a modificações nos padrões de comportamento mental e emocional. Como toda garota da sua idade, Alice percebe as roupas apertando, por causa dos seios que crescem, e já sabe muito bem que, em breve, mensalmente irá sangrar. Sob o aspecto psicológico, se por um lado já se encontra atraída pelo rapaz dentuço com quem ocasionalmente encontra no metrô, a ponto de segui-lo, por outro, convive também com sentimentos de isolamento, solidão e confusão.

Fantasias, devaneios e o hábito de escrever um diário são os instrumentos de que a garota se utiliza como auxiliares nesse período de transição, em que se perdem as referências dos objetos da infância, como as brincadeiras com a cachorrinha Diná, por exemplo, e ainda não se estabeleceram claramente as relações a partir das quais serão construídas as bases para o desenvolvimento da vida adulta. As várias faces de Tersie Tolly ajudam Alice a empreender a transformação. A agente secreta e a escritora, em cumplicidade, conduzem a pulsão

${ }^{367}$ Alice no metrô, p. 5. 
para o desconhecido, para a sexualidade. A domadora de tigres representa a coragem para enfrentar a mãe e as adversidades do mundo. $O$ anjo atua na defesa, garante a integridade psíquica. A extraterrestre avaliza a identidade, a diferenciação referentemente ao outro. O poder de sedução é exercido pela atriz, enquanto que a treinadora de pássaros permite buscar no sonho um contraponto para a realidade. $A$ posição intermediária entre esses dois extremos é desempenhada pelo diário, por meio do qual a adolescente confessa tudo aquilo que ainda não pode ser partilhado com os adultos.

A Alice desta história também desce às profundezas da Terra, corre atrás de um "coelho" apressado, com quem demora a se encontrar, voa para dentro, voa pra fora, cresce, encolhe, defende-se de "ratos", nada nas próprias lágrimas, defronta-se com duquesas, enfrenta a rainha má, atravessa espelhos que the fazem revelações, tudo como a famosa personagem de Lewis Carrol. A diferença entre as duas é que, para uma, as fantasias têm a função de regular as ansiedades relativas aos conflitos inerentes ao processo de individuação, próprio da infância; para a outra, atuam no sentido de atenuar as características narcisistas típicas da adolescência e de possibilitar experiências pessoais mais voltadas à participação social. Por meio da fantasia, a menina e a mocinha realizam desejos, resolvem problemas, distorcem, mas também corrigem a vida real.

\subsubsection{Um outro Marco Pólo. Ilustrações de Gennaro Urso. São Paulo, Melhoramentos, 1990. 88 p. \\ (C) 1989 - Leitor crítico. Realismo humanitário.}

Marco Pólo, mercador italiano, nasceu no ano de 1254, em Curzola, Dalmácia (atual Croácia) então província veneziana. Em 1271, acompanhado do pai e do tio, parte para o Extremo Oriente, em viagem que duraria 24 anos. Só na China, aonde chegará em 1278, permanecerá por 17 anos, exercendo inclusive funções administrativas e diplomáticas na corte do soberano mongol Kublai Khan, neto de Genghis Khan.

Em 1295, os Pólo voltam à Veneza, carregados de riqueza e especiarias. Três anos depois, em batalha entre venezianos e genoveses, Marco Pólo é feito 
prisioneiro. Na prisão, em Gênova, narra suas aventuras a Rusticiano (ou Rustichello), de Pisa, conhecido como escritor em langue d'oïl. Ghirardi explica: ${ }^{368}$

Nesta língua transcreveu Rusticiano as narrativas do viajante, que hoje se conservam não no original (perdido), mas em diversas traduções italianas medievais. Surgiu assim o texto que veio a ser popularmente conhecido como Milione, título de significado discutido, provavelmente nome familiar vindo de um antepassado (Emilione) ou talvez calcado no latim (milia), com manifesta alusão à longa viagem narrada.

Também conhecido como O livro das maravilhas: a descrição do mundo, Milione transforma-se em uma das mais famosas narrativas de viagem de todos os tempos, traduzida em vários idiomas. Segundo Machado e Pageaux, o relato de viagem pode tornar-se uma espécie de tema literário e servir de modelo para outras formas literárias. Esclarecem os autores: ${ }^{369}$

$\mathrm{Na}$ narrativa de viagem, o escritor-viajante é ao mesmo tempo produtor da narrativa, objecto, por vezes privilegiado, da narrativa, organizador e encenador da sua própria personagem. Ele é assim narrador, actor, experimentador e objecto da experiência. Ou ainda, o memorialista dos seus feitos e dos seus gestos, herói da própria história que inventa e que arranja à sua maneira, testemunha privilegiada em relação ao público sedentário e, enfim, contador para gáudio deste.

Lino de Albergaria utiliza esse procedimento narrativo de modo ficcional, ao criar Marcos Paulo, o narrador autodiegético de Um outro Marco Pólo. O enredo da obra configura-se como uma verdadeira narrativa de viagem, durante a qual o protagonista irá experimentar aventuras propulsoras do desenvolvimento psicológico característico da adolescência.

Tudo começou quando, como conseqüência de uma greve de professores, Marcos Paulo encontrava-se em férias forçadas, fora de época. Além disso, a crise econômica que assolava o País, após a implantação do Plano Cruzado, obrigara seus pais a hospedarem em casa um pensionista. Seu Prisciliano, velho e solitário,

${ }^{368}$ GHIRARDI, Pedro Garcez. O relato de Marco Pólo e a Nova Floresta de Bernardes. Disponível em: http://www.hottopos.com.br/notand5/marcpolo.htm. Acesso em: 27 nov. 2006.

${ }^{369}$ MACHADO, Álvaro Manuel e PAGEAUX, Daniel-Henri. Da literatura comparada à teoria da literatura. Lisboa, Edições 70, s/d., p. 34. 
viera ocupar justamente o quarto do garoto, que tivera de se mudar para um pequeno quartinho, mal iluminado, onde a mãe guardava as roupas que vendia, como "sacoleira".

A princípio, a presença do pensionista parecia mais um incômodo do que uma solução. Aos poucos, no entanto, Marcos Paulo e Prisciliano foram ficando amigos. Nos passeios que os dois faziam pelo bairro onde moravam, o garoto passou a conhecer melhor a maneira de ser e de pensar daquele velho, que tinha muitas histórias para contar. Eram histórias de amor, de trabalho, de aventuras, enfim, de formas diferentes de viver a vida, em geral passadas em cidades distantes e, até mesmo, em países estrangeiros.

Para Marcos Paulo, que não conhecia nada além de Belo Horizonte, e que vivia a sonhar com as viagens longínquas feitas por Marco Pólo, Prisciliano passou a representar uma ligação com um mundo maior. Mais do que isso, tornou-se mesmo uma espécie de referência masculina. A identificação entre ambos foi tanta que o velho convidou o garoto para uma viagem a Ouro Preto e Mariana.

Foi nessa cidade, com nome de mar e de mulher, que Marcos Paulo, numa única noite, viveu experiências relativas à transição da pré-adolescência para a adolescência propriamente dita. Como num rito de passagem, percebeu os conflitos que ficaram para trás e os desafios que o esperavam no futuro. Em outras palavras, descobriu a diferença entre os direitos da juventude e as obrigações da vida adulta, sentiu na pele as nuanças entre o sentimento sublime do amor e a pulsão arrebatadora do desejo sexual. Enfim, adquiriu conhecimentos que iriam modificar sua visão de mundo e suas atitudes diante da realidade. E, tudo isso, sempre com muita consciência, como se nota:

Vida de viajante era assim, então: conhecendo outros lugares e gente diferente. [...] Não tinha ainda dois dias que saíra de casa e parecia que eu já havia crescido e envelhecido... É que deixar de ser criança é ir ficando mais velho, eu acho. ${ }^{370}$

De volta à cidade natal, ao lar paterno e à escola, Marco Pólo nunca mais seria o mesmo. Embora continuasse a devanear com um futuro repleto de 
possibilidades, conseguiu trazer todos os seus sonhos para bem mais próximos da realidade.

\subsubsection{O relógio do mundo. Ilustrações de Rogério Borges. 16. ed., São} Paulo, Atual, 2005. 64 p.

\section{(C) 1989 - Leitor crítico. Maravilhoso metafórico e folclórico}

Duas cidades: uma comum, uma mágica. Entre elas, uma floresta e um segredo. A cidade comum é Cravo Branco, ao Sul; a mágica, é Cucura, ao Norte. O segredo é uma mina de ouro subterrânea, escondida abaixo do leito do rio que corta a densa mata. Esse é o tópos a partir do qual Lino de Albergaria cria O relógio do mundo, narrativa em que são abordados temas como rito de iniciação, ida ao encontro do desconhecido, passagem para a idade adulta, preservação da natureza, convívio com os animais, respeito às tradições, aceitação pacífica das diferenças sociais e culturais, entre outros.

A história inicia-se quando os habitantes de Cravo Branco ficam sabendo da existência do ouro pelo "último índio". A partir de então, dominados pela cobiça, invadem a mata à procura do rico minério. É quando a gente de Cucura decide socorrer a floresta, porque precisava dela para se manter encantada. A mata por sua vez também reage, fazendo brotar novas árvores, que, sempre maiores e com mais vigor, começam a invadir Cravo Branco.

Lá, morava Casemiro Correia, caçula de uma família de doze filhos homens, cujo pai era o Capitão. Decidido a lutar contra as forças de Cucura, o homem mandava um filho após o outro enfrentar a floresta. Mas, amedrontados, todos fugiam. Em vez de seguirem rumo Norte, partiam para o Sul. Até que chegou o dia em que só sobrou Casemiro Correia. O menino passava os dias a tratar do jardim de casa, atento para que o mato não estragasse os canteiros de cravo branco, que ele tão cuidadosamente cultivava. Essa situação, no entanto, não demora a se modificar.

Bastou que uma coruja piasse, primeiro de noite, depois de dia, para que Cornélio Correia, o Capitão, mandasse à luta o último filho, impondo ao garoto a missão de acabar com a vida do pássaro, considerado mau agourento. Intuitivamente, porém, Casemiro sabia que a coruja voaria para algum lugar misterioso, sobre o qual ele tinha muita curiosidade. Mesmo armado com a pesada 
espingarda que o pai o obrigara a carregar, ele não tinha a menor certeza se devia ou não matar a ave. Cheio de dúvidas e conflitos, o garoto embrenha-se na mata, sem saber que uma borboleta cor de prata, símbolo de Cucura, o seguia. Também não se dava conta, tampouco, do fato de que, desde que acordara naquele dia, vinha diminuindo de tamanho e de que havia perdido mais alguns centímetros no momento em que entrara na floresta.

Daí em diante, rumo a seu destino, o garoto irá viver várias aventuras dignas dos mais tradicionais contos maravilhosos, desde cair num poço profundo e ver-se no interior de uma gruta - na qual encontra espécies de índios guardiões d'O relógio do mundo, local sagrado onde o "ferro amadurece em ouro" - até ser recebido pelos reis "sem idade" de Cucura. Durante a jornada de três anos, Casemiro enfrenta duras provações impostas ora por animais selvagens, como os caititus, porcos-domato, ora pelas intempéries, como a cruviana enlouquecida, ora por seres sobrenaturais, como a Caipora. No final, vê-se transformado em adulto, pronto para retornar a Cravo Branco, casar-se com Cordélia Camarão e assumir, no lugar que era de seu já falecido pai, o comando da cidade. Sua missão será a de restabelecer o equilíbrio entre os dois mundos, perdido como conseqüência da ambição dos homens comuns.

Sobre o processo de criação da obra, diz o autor ${ }^{371}$ :

O relógio do mundo foi minha primeira tentativa de um conto de fadas ou de uma história maravilhosa. Pesquisei em Câmara Cascudo. O livro é uma homenagem a ele, pois as personagens e lugares começam todos com a letra "C", a inicial de Cascudo. [...] É claro que tem também influência de Vladimir Propp, Marie-Louise Von Franz e de outros autores.

Além de estar presente no nome das personagens e dos lugares, a letra "C" aparece gravada da capa do livro mágico de Cucura, o qual contém "informações sobre tudo o que começa com aquela letra" ${ }^{372}$. É por meio desse livro, que se vai conhecer o significado do nome da personagem principal: Casemiro, "o instituidor, o autor da paz". ${ }^{373}$

\footnotetext{
${ }^{371}$ E-mail enviado a este pesquisador em 8 de junho de 2005.

372 O relógio do mundo, p. 45.

${ }^{373}$ Ibidem, p. 45.
} 
No texto, as referências ao folclore brasileiro são várias. A Caipora já citada, por exemplo, é descrita por Câmara Cascudo ${ }^{374}$ da seguinte maneira:

[...] Em qualquer direção, pelo interior do Brasil, o Caapora-Caipora é um pequeno indígena, escuro ágil, nu ou usando tanga, fumando cachimbo, doido pela cachaça e pelo fumo, reinando sobre todos os animais e fazendo pactos com os caçadores. [...] No Ceará, além do tipo comum, aparece com a cabeleira hirta, olhos de brasa, cavalgando o porco, caititu, e agitando um galho de japecanga.

Essa descrição coincide com a da obra em estudo. A diferença é que Albergaria utiliza a personagem na forma característica quando a ela nominalmente se faz referência como Curupira ${ }^{375}$, cujos pés são inversos: os calcanhares para frente, os dedos para trás.

Inspirado também na tradição folclórica é o nome de um dos quatro índios que fazem a segurança da gruta de ouro. Trata-se de Caboré, palavra que, entre outras acepções, designa um tipo de caboclo ligeiramente mais claro. "Indígenas cariris, aliados aos janduís, no Rio Grande do Norte" ${ }^{376}$. Há ainda no conto a presença importante da coruja, compreendida inicialmente como símbolo da morte iminente de alguém enfermo, do mesmo modo como alude à ave Câmara Cascudo $^{377}$. Pode-se fazer referência ainda a cravo branco. A flor que dá nome à cidade onde mora a personagem principal é, no dizer do folclorista ${ }^{378}$, tradicional dos namorados, "indispensável no código dos sinais dos namorados".

Com relação à estrutura narrativa, o tema central abordado em 0 relógio do mundo - rito de iniciação - permite que a obra seja classificada dentro do subgênero conto maravilhoso, uma vez que segundo Machado e Pageaux ${ }^{379}$, o tema, assim como o mito, tem função estruturante no processo constitutivo do texto literário.

${ }^{374}$ CASCUDO, Luís da Câmara. Dicionário do folclore brasileiro. 11.ed., São Paulo, Global, 2002, p.

375 Idem, ibidem, p. 172.

${ }^{376}$ Idem, ibidem, p. 90.

377 Idem, ibidem, p. 164.

${ }^{378}$ Idem, ibidem, p. 165.

${ }^{379}$ MACHADO, Álvaro Manuel e PAGEAUX, Daniel-Henri. Da literatura comparada à teoria da literatura. Lisboa, Edições 70, s/d., p.116. 


\subsubsection{O correspondente estrangeiro. Ilustrações de Marcelo Moreira.} São Paulo, Ed. do Brasil, 1988. 32 p.

() 1988 - Leitor crítico. Realismo humanitário.

A preocupação com o tema da consciência negra está presente neste $O$ correspondente estrangeiro. Trata-se da história de um garoto afro-descendente que, por ter a pele clara, como conseqüência de miscigenação, manifestava, até uma determinada fase de seu desenvolvimento, comportamento preconceituoso contra pessoas pobres e da raça negra.

O gênero narrativo escolhido pelo autor, como o próprio título da obra sugere, é o do romance epistolar. Por meio de uma única e longa carta, Mori (apelido de Morisson), o protagonista, narra a Konare, seu correspondente africano, como conseguiu se conscientizar a respeito dos preconceitos enraizados na sua formação. Em tom assumidamente confessional, o garoto brasileiro faz um mea-culpa, no qual não faltam críticas à cultura implantada pela classe média de descendência européia no Brasil.

A expressão não-linear do pensamento de Mori, volta e meia interrompido por digressões, cria o efeito de naturalidade tão necessário ao estilo coloquial proposto para a construção do texto. Ideologicamente falando, as opiniões do garoto revelam de maneira contundente o problema do racismo em um país no qual se criou e se perpetua falsamente $\mathrm{o}$ mito da democracia racial. $\mathrm{O}$ trecho abaixo exemplifica minimamente o teor da obra. Escreve Mori:

Cê deve estar achando que sou bem antipático, cheio de preconceito... Mas até este ano eu era assim mesmo... E pelo menos eu era. Mas muita gente ainda é. Ou você acha que fui eu que inventei que tem gente pior do que eu?

Minha mãe mesmo foi na escola protestar por eles terem me misturado com a meninada da favela... Meu pai, se ganhasse mais, me tirava e também meus irmãos, da escola da prefeitura... e quando ele justifica da gente estar ali, diz que o mundo é assim, que a gente precisa conviver com tudo quanto é tipo de gente pra aprender a se defender melhor... Ele diz que o mundo é assim e parece que nunca pensou que pudesse ser diferente... ${ }^{380}$

${ }^{380} \overline{O \text { correspondente estrangeiro, p. } 6 .}$ 
7.1.19 Nosso muro de Berlim. Ilustrações de Paulo Bernardo. 4. ed., São Paulo, FTD, 1991. 40 p.

() 1988 - Leitor crítico. Realismo crítico

Lado de lá ou lado de cá é apenas uma questão de ponto de vista. A partir dessa verdade inquestionável que se constrói o sentido de Nosso muro de Berlim. $\mathrm{Na}$ área de Narratologia, ponto de vista é um conceito também conhecido pelos termos visão, restrição de campo, foco narrativo, focalização. Segundo Reis e Lopes $^{381}$, "focalização pode ser definida como a representação da informação diegética que se encontra ao alcance de um determinado campo de consciência, quer seja o de uma personagem da história, quer o do narrador heterodiegético". No livro sobre o qual se trata, Lino de Albergaria utiliza o recurso da focalização como elemento discursivo de importância fundamental para a significação global da obra.

Ao criar dois narradores, que detém campos de consciência diferentes a respeito dos fatos narrados e que se alternam na condução do enredo, o autor estabelece uma apropriada correlação semântica entre os planos da forma e do conteúdo do texto. No extenso pátio de uma escola, os alunos distribuem-se entre os dois lados da linha demarcada por alguns pés de jabuticabas. A um dos lados, pertence Tino, ao outro, Elisa. Eles não se conhecem até que, por conta de uma brincadeira de esconde-esconde, a garota acaba atravessando para a parte do terreno onde estava o rapaz. Naquele momento, ele disputava com os amigos um jogo de plantar bananeira, cujo vencedor seria quem ficasse mais tempo de pontacabeça.

É fato comum pré-adolescentes organizarem-se em turmas ou gangues, regidas por determinadas leis territoriais e/ou normas de conduta, exatamente como se passa em Nosso muro de Berlim. Conforme o próprio título sugere, o espaço físico da escola estava dividido pelo conjunto de jabuticabeiras (o muro metafórico) entre duas turmas de comportamentos diferentes.

Mas o cerco vez ou outra era furado. Depois da primeira visita, Elisa pensa em voltar para o outro lado, não só com a esperança de rever Tino, por quem havia sentido certo interesse, mas também por acreditar que daquele outro lado meninos e meninas brincavam juntos, o que dificilmente ocorria entre os colegas da sua turma.

${ }^{381}$ Dicionário de narratologia. 5.ed., Coimbra, Almedina, 1996, p. 165. 
A fase típica da pré-adolescência masculina, antes de uma passagem bem-sucedida para a masculinidade, recebe sua qualidade característica do emprego da defesa homossexual contra a angústia da castração. É precisamente essa solução defensiva do menino, subjacente ao seu comportamento grupal típico que foi classificada pela psicologia descritiva como 'fase da gangue' [diferente da gangue de rapazes adolescentes mais velhos]. A psicologia psicanalítica a ela se refere como a "fase homossexual" da pré-adolescência.

Deve-se distinguir essa fase de uma outra [...]. Na fase homossexual pré-adolescente do menino, a inclinação pelo mesmo sexo é uma manobra para evitar o sexo oposto. ${ }^{382}$

Elisa, porém, não imaginava o outro tipo de sentimento separatista que predominava naquela parte do pátio. Sua presença ali não tinha sido nem um pouco bem-vinda. Ao contrário, chegou a ser considerada verdadeira intrusão, principalmente pelas meninas. Tal intolerância, mais dia menos dia, só podia resultar em guerra entre os alunos das duas partes da escola. Durante a batalha, municiada de pastas, cadernos e sapatos, a garota era julgada como a principal espiã. Pensa Tino:

Então era isso... aquela menina rindo pra mim... que me fez até cair da bananeira... era espiã deles!

Fiquei [...] furioso comigo de ter me interessado por aquela menina. $E$ amaldiçoei todas as mulheres. $E$ achei que todo sorriso de mulher era um sorriso de traição. ${ }^{383}$

Como se nota, é a fase da pré-adolescência, em que meninos desprezam meninas e se comprazem em jogos exibicionistas, e meninas apresentam atitudes masculinas, que está representada na obra, escrita em 1988, um ano antes da queda do muro de Berlim. O fato histórico, no entanto, não invalida a perenidade do texto, pois pode suscitar a reflexão sobre a época da Guerra Fria e do colapso dos regimes do leste europeu. Além disso, veicula valores universais ao exemplificar padrões comportamentais típicos de um determinado estágio do desenvolvimento

${ }^{382}$ BLOS, Peter. Adolescência: uma interpretação psicanalítica. 2.ed., São Paulo, Martins Fontes, 1998, p. 89.

${ }^{383}$ Nosso muro de Berlim, p. 23. 
psíquico. E mais, ao apresentar dois focos narrativos, oferece condições para a orientação de novas práticas de leitura, segundo explica Coelho ${ }^{384}$ :

O convívio do leitor crítico com o texto literário deve extrapolar a mera fruição de prazer ou emoção e deve provocá-lo para penetrar no mecanismo da leitura.

O conhecimento de rudimentos básicos de teoria literária faz-se necessário; pois a literatura é a arte da linguagem e como qualquer arte exige uma iniciação.

\subsubsection{A outra menina. Ilustrações de Mario Vale. São Paulo, Ed. do} Brasil, 1988. 30 p.

(C) 1988 - Leitor crítico. Realismo mágico.

Em Semiótica discursiva, a categoria da veridicção é constituída pela colocação em relação de dois esquemas: parecer / não-parecer, chamado manifestação; ser / não-ser, conhecido como imanência. "É entre essas duas dimensões da existência que atua o 'jogo da verdade': estabelecer, a partir da manifestação, a existência da imanência, é decidir sobre o ser do ser", explica Greimas $^{385}$.

Em A outra menina, Lino de Albergaria propõe ao leitor justamente essa tarefa de decidir sobre a imanência ou não das experiências vivenciadas por Sara, a protagonista, em seu encontro com lara, nome convencional e literário da Mãed'água. Cascudo ${ }^{386}$ registra a origem dessa figura lendária.

Em todo o Brasil conhece-se por mãe d'água a sereia européia, alva, loura, meio peixe, cantando para atrair o namorado, que morre afogado querendo acompanhá-la para bodas no fundo das águas. O mito é morfologicamente europeu, do ciclo atlântico, posterior à poesia de Homero, para quem as sereias eram aves e não peixes cantando.

${ }^{384}$ COELHO, Nelly Novaes. Literatura infantil: teoria, análise, didática. São Paulo, Moderna, 2000, p. 40.

${ }^{385}$ GREIMAS, A. J. e COURTÉS, J. Dicionário de semiótica. São Paulo, Cultrix, s/d., p. 488.

${ }^{386}$ CASCUDO, Luís da Câmara. Dicionário do folclore brasileiro. 11.ed., São Paulo, Global, 2002, p. 348. 
Lino de Albergaria transporta, pois, a lara para Lagoa Funda, fictícia região hidrográfica onde Lia, mãe de Miriam, amiga de Sara, mantinha casa de veraneio. No local, corria a lenda de que havia uma cidade submersa na lagoa. Alguns diziam que embaixo das águas habitava uma comunidade indígena. Outros acreditavam na existência de um povoado cristão, "com igreja e tudo", que tocava o sino certos dias do ano.

Foi em umas férias na casa de Lia que Sara conheceu Amaro, rapaz estranho, de olheiras profundas, pele fria e unhas arroxeadas, que tinha fama de sonâmbulo e parecia enfeitiçado. Atraída pelo rapaz, a garota sente-se fortemente impulsionada a desvendar seus segredos e pensamentos. Como se guiada pela intuição, travará feroz luta com a lara, determinada a salvar Amaro do feitiço da Mãe d’Água.

É referentemente a esse embate que as possibilidades de leitura criadas pelo narrador são modalizadas, semioticamente falando, por meio da relação de contrariedade entre o ser e o parecer, responsável pela criação do significado mágico do texto. O recurso narrativo utilizado empresta à obra uma pluralidade de efeitos de sentido, que será integralmente viabilizada (ou não) de acordo com o grau de competência discursiva do leitor. Como poderá ele entender determinadas passagens do livro? Contato do real com o sobrenatural? Imaginação? Sonho? Premonição?...

Sob o aspecto psicanalítico, pode-se dizer que o confronto de Sara com a lara representa metaforicamente o desabrochar da pulsão heterossexual, característica de determinada fase do desenvolvimento psicológico. Em outros termos, Sara encontra-se na fase em que abandona a pré-adolescência e ingressa na adolescência propriamente dita, e descobre dentro de si o esboço de uma mulher exuberante e sedutora. Resta saber se ela conquista ou não Amaro.

\subsubsection{Uma cor dentro da terra. Ilustrações de Regina Rennó. São} Paulo, Melhoramentos, 1986. 114 p.

(C) 1986 - Leitor crítico. Realismo humanitário.

"O que seria do amarelo, se todos só gostassem do azul?" A expressão popular dá o tom do questionamento de Guido, personagem principal de Uma cor dentro da terra, história de uma família classe média habitante da cidade de Belo 
Horizonte. O garoto vivencia o momento da vida a que os psicanalistas dão o nome de "moratória", conforme esclarece Calligaris ${ }^{387}$ :

[...] Ao longo de mais ou menos 12 anos, as crianças, por assim dizer, se integram em nossa cultura e, entre outras coisas, elas aprendem que há dois campos nos quais importa se destacar para chegar à felicidade e ao reconhecimento pela comunidade: as relações amorosas / sexuais e o poder (ou melhor, a potência) no campo produtivo, financeiro, social.

[...] logo nesse instante, Ihes é comunicado que não está bem na hora ainda.

Guido, como os demais meninos que entram na adolescência, estão em busca de suas preferências com relação ao sexo oposto e de suas aptidões no que se refere ao talento profissional. Para alguns, a certeza do que querem alcançar surge com certa naturalidade, como se a acompanhar o próprio desenvolvimento. Para outros, o processo de descoberta ocorre mais lentamente. A diferença é ilustrada por algumas conversas que o protagonista mantém com o colega Tadeu, ao logo do enredo. Pergunta o amigo:

— [...] Queria só saber o que é amarelo para você, cara. Se você não me falar, vou achar impossível dizer uma coisa de que você é a fim de verdade. Até hoje você não sabe o que te interessa na vida... ${ }^{388}$

A resposta de Guido aparece apenas alguns capítulos depois, em outra situação, quando o diálogo dos dois gira em torno do desejo por meninas:

— Você sabe de tudo que te interessa. Matemática, vôlei, pernas, calcinhas. Só que o tempo certo pra você ainda não chegou! [rebate Guido].

— Mas vai chegar! Vai chegar! É só questão de tempo, mesmo. ${ }^{389}$

Esse é, pois, um tempo de espera. Saiba ou não o que quer, o adolescente, apesar de ter o corpo, a mente e o espírito preparados para a competição que caracteriza a sociedade, não é reconhecido como adulto. Condição imposta pelas

${ }^{387}$ CALLIGARIS, Contardo. A adolescência. São Paulo, Ed. Publifolha, 2000, pp.14-5

${ }^{388}$ Uma cor dentro da terra, p. 22.

389 Ibidem, p. 44. 
formas de organização da cultura ocidental na atualidade, a moratória será vivenciada com mais ou menos facilidade, de acordo com as circunstâncias familiares que cercam o desenvolvimento dos jovens. No caso de Guido, os conflitos internos são intensificados pelo estado de distanciamento que nota na relação dos pais e pela falta de identificação com o comportamento dos irmãos.

Teresa, professora de Lingüística, não obstante fosse mãe afetuosa, vivia estressada, às voltas com a redação de sua tese de doutorado. Edmir, o pai, insatisfeito com o tipo de trabalho que desenvolvia na editoria de pesquisa do jornal Estado de Minas, acaba se apaixonando por Luísa, a estagiária de Jornalismo bem mais nova que ele. Mariana, a irmã, estudante de balé, demonstra-se a melhor aluna da academia, e logo é convidada a lecionar. O irmão mais novo, Marcelo, deslumbra-se com o estilo de vida dos colegas mais ricos, e não tarda a manifestar interesse por ser guitarrista de uma banda de rock.

Assim, em meio às demais personagens, voltadas cada uma para seus próprios objetivos, Guido, de natureza introspectiva, é quem mais sofre com a sucessão dos acontecimentos: a separação dos pais, o namoro assumido de Edmir e Luísa, a presença em casa do professor Ivo, pretendente a um relacionamento afetivo com a mãe. Esses fatos, rapidamente assimilados por Mariana e Marcelo, são digeridos com dificuldade pelo rapaz. Só mesmo quando as necessidades interiores começam a ficar mais claras, e conseqüentemente satisfeitas, é que Guido passa a ter condições de aceitar as idiossincrasias alheias e a reconhecer que se parece em muito com o pai. Quando encontra o amor e, paralelamente, o que seria o "amarelo" para ele, percebe a alma serenar, como se pronta a empreender mais uma etapa do desenvolvimento.

Na obra, a manifestação dos padrões universais do comportamento humano é revestida por características regionais de onde se desenrola o enredo. $O$ amarelo, que simboliza a procura de Guido por um ideal, surge em "algum instante entre o dia e a noite" ${ }^{390}$, no céu de Belo Horizonte, e "no ouro escondido lá no fundo da terra". 391 Mas a cor local aparece também, de forma bastante significativa, no modo de falar de Doralda, a empregada da família, para quem, o frango sem quiabo, ia "sê

\footnotetext{
390 Ibidem, p. 25.

391 Ibidem, p. 100.
} 
muito sozinho". 392 Em trecho de referência explicita a Guimarães Rosa, Edmir comenta:

- Uma cozinheira falando assim é fantástico! É ter em casa um pedaço puro de Minas... ${ }^{393}$

É nesse "pedaço puro" de Minas Gerais que Lino de Albergaria ambienta a história de Uma cor dentro da terra, representativa dos conflitos típicos da adolescência em todo o mundo ocidental.

\subsubsection{Crescendo na quadra. Porto Alegre, L\&PM, 1986. 144 p.}

(c) 1986 - Leitor crítico. Realismo crítico, histórico e humanitário.

Em Crescendo na quadra, a história do Brasil do meio da década de 1980, além de representar o pano de fundo narrativo, a partir do ponto de vista de uma família de subúrbio de Belo Horizonte, é determinante para as ações das personagens. Naqueles anos politicamente conturbados, em que o sentimento de baixa-estima do povo brasileiro oscilava entre falsas esperanças e muitas desesperanças, o País vivenciou a transição da ditadura militar para o período que se tornou conhecido como Nova República.

Para além dos acontecimentos políticos, à época ocorreram profundas transformações na sociedade brasileira, registradas com argúcia nesta obra de Lino de Albergaria. O início do enredo é marcado pelo comício das Diretas Já, em 1984, na capital mineira. Figuras de destaque no cenário nacional, reconhecidas pela luta institucionalizada que empreenderam contra o regime autoritário, desfilam no palanque montado na Avenida Afonso Pena: Leonel Brizola, Franco Montoro, Ulisses Guimarães, Tancredo Neves. Entre esses, alguns artistas engajados: Milton Nascimento, Fafá de Belém, Maitê Proença.

A partir daí, o leitor acompanha a evolução física, mental e emocional da protagonista Júlia, estudante do Ensino Médio, em sua luta para vencer num esporte que começava a ser mais bem divulgado pela mídia, especialmente pelos bons resultados da seleção masculina nas Olimpíadas. A despeito das buscas individuais, pode-se dizer que a trajetória da garota é ilustrativa das dificuldades enfrentadas

\footnotetext{
${ }^{392}$ Ibidem, p. 14.

${ }^{393}$ Ibidem, p. 30.
} 
pelos jovens daquele tempo, particularmente dos oriundos da classe média baixa, obrigados a freqüentar escolas públicas, nas quais a qualidade de ensino havia sido sistematicamente deteriorada durante os anos da ditadura. Greve de professores, apoiadas por estudantes, eram quase que anualmente deflagradas, com o objetivo de revalorizar a profissão.

Como se emergidos de um período de total alienação e pressionados por uma realidade altamente competitiva e socialmente injusta, muitos dos adolescentes de então começaram a perceber que a única saída que lhes restava era a de empreender esforços sobre-humanos para tornarem-se melhor informados, mais bem preparados e conscientemente politizados, como forma de vencerem na vida. Outro exemplo apresentado na obra é o de Alvinho, namorado de Júlia, que divide seu tempo entre os estudos e o trabalho no bar de propriedade do pai, na periferia da cidade. O rapaz, politicamente engajado na corrente dita progressista, busca ingressar na faculdade de Comunicação Social, área que se configurava como bastante promissora.

A discrepância entre a ânsia por ativismo da juventude e o conformismo da geração anterior é gritante. Os pais da garota demonstram essa passividade. Pedro, desempregado, não consegue reciclar-se. Angustiado, beira o alcoolismo. Marisa, professora da rede estadual, é inicialmente incapaz de ter uma atitude pró-ativa nas manifestações da classe. Só aos poucos começa a rever essa posição. Leia-se um de seus depoimentos:

-É, eu nunca participei de uma greve, só ficava em casa para não furar o movimento. Cuidava melhor da casa, pregava todos os botões, fazia todas as bainhas que não faço durante o ano... Trabalhava pra mim e deixava os outros brigando... ${ }^{394}$

Mas a passagem do tempo e os fatos históricos iriam chacoalhar todas as estruturas cristalizadas de um país que, durante quase 30 anos, havia estado à margem das principais transformações sociais ocorridas nas nações que compõem o chamado Primeiro Mundo. A personagem Julião, avô de Júlia, expressa bem o sentimento coletivo, com a seguinte frase:

${ }^{394}$ Crescendo na quadra, p. 114. 
- Pois a gente tá precisando mesmo de um bom benzedor pra tirar o quebranto desse Brasil... ${ }^{395}$

Instalada pelo sentimento generalizado de falta de perspectivas, a inércia do povo brasileiro viria a ser sacudida, para o bem ou para o mal. A pressão nas ruas para que houvesse eleições diretas à presidência da república, além de demonstrar o grau de insatisfação da população, revelou a face oculta e ofuscou o poderio da maior emissora de televisão do país, espécie de órgão oficioso de imprensa do regime instalado.

$\mathrm{Na}$ educação, além do sucateamento da infra-estrutura, as concepções e os métodos de ensino mostraram-se defasados, apontando para a necessidade de reformas urgentes, a partir do investimento em pesquisas e novas tecnologias relacionadas com as mais variadas áreas do saber.

No setor econômico, o contraste entre o Brasil moderno e o antigo ainda se fazia sentir acentuadamente, simbolizado na obra pela coabitação em um sítio em Varginha de Julião e sua filha Vanda, de idéias avançadas. Nota-se que, nas zonas rurais, agriculturas de subsistência paulatinamente davam lugar às monoculturas de cana-de-açúcar (em razão do Proálcool) e de soja, entre outras. O livro faz menção ao novo ciclo do café verificado no Sul de Minas de Gerais. Nas grandes cidades, a concentração exagerada de riquezas, da qual os lucros estratosféricos dos banqueiros são emblemáticos, explodiam greves de bancários em reivindicação por melhores salários. Após a frustrada eleição indireta de Tancredo Neves para presidente, o Brasil, no comando de José Sarney, irá conhecer inúmeros planos econômicos mirabolantes, criados com o objetivo de conter a inflação desenfreada dos preços.

Em meio a tantos abalos das instituições tradicionais, sobretudo, é no campo do comportamento que as mudanças irão se mostrar mais intensamente. Sob esse aspecto, Júlia é uma espécie de ícone da geração que reafirmou a emancipação feminina. Além das vitórias no vôlei, jogo cujos investimentos voltavam-se mais para a categoria masculina, a garota conquistou o direito consentido pela família de dormir com o namorado, hábito até então inconcebível e que se tornou comum entre as adolescentes do século XXI. No plano coletivo, observam-se como determinadas tendências surgidas na década de 1980 vieram posteriormente e a se consolidar.

${ }^{395}$ Ibidem, p. 54. 
Entre essas, são significativas: o alto nível que atingiu a prática do vôlei no País, especialmente após a criação em Saquarema $(R J)$ do Centro de Desenvolvimento do Vôlei, único no mundo dedicado exclusivamente à modalidade; a proliferação das igrejas evangélicas, em suas diversas ramificações; a onda do culto ao corpo, impulsionada pela ginástica aeróbica; a incansável busca por métodos cada vez mais sofisticados de manutenção da aparência jovem; o delineamento de um perfil de adolescente impregnado de valores consumistas, característico da classe média alta; a entrada do Brasil na rota dos megashows internacionais, a partir da realização do primeiro Rock in Rio, em 1985; a popularização e profissionalização da prática de outros tipos de esporte além do futebol; tudo isso, entre demais fenômenos aludidos no enredo.

Mas nem só por transformações ficaram marcados aqueles tempos. Com relação aos poderes que constituem o sistema republicano, nota-se, ao ler Crescendo na quadra, que pouca coisa mudou no País de antes e depois da ditadura militar. Uma conversa entre Júlia e Alvinho, durante as comemorações do Sete de setembro, ilustra bem essa realidade. Diz o rapaz:

- O Brasil está voltando a crescer, mas o brasileiro mal se beneficia desse crescimento...

- Alvinho, será que você vai acabar virando político? [pergunta a garota].

- Não, eu só tenho simpatia por certas idéias. Os políticos acabam sempre me decepcionando... ${ }^{396}$

Como se disse inicialmente, é num contexto social bastante dinâmico que se movem as personagens desta narrativa ágil, essencialmente construída por diálogos que soam naturais e verossímeis. Em meio ao panorama histórico vibrante, desenrola-se uma singela e comovente história de amor.

\subsubsection{Tantas histórias tem o tempo... São Paulo, Ed. do Brasil, 1985.}

32 p.

(C) 1985 - Leitor crítico. Realismo mágico.

Sobre as tendências temáticas e estilísticas da literatura juvenil contemporânea, destacam-se cinco linhas básicas, que por sua vez se desdobram

${ }^{396}$ Ibidem, p. 120. 
em outras. Entre essas últimas, encontra-se aquela identificada como realismo mágico. Segundo Coelho ${ }^{397}$, fazem parte dessa classificação obras "em que as fronteiras entre realidade e imaginário se diluem, fundindo-se as diferentes áreas para dar lugar a uma terceira realidade, em que as possibilidades de vivências são infinitas e imprevisíveis".

Lino de Albergaria, em Tantas histórias tem o tempo... faz o mágico irromper na realidade cotidiana da pequena Gaiola, cidade do interior do Brasil, que, segundo as características, bem poderia localizar-se em algum recanto afastado entre os estados de São Paulo e Minas Gerais. Nesse pequeno vilarejo, onde existiam poucas ruas com muita poeira e só algumas tinham calçamento, de paralelepípedos, a suposta visita de uma nave espacial dividia as opiniões.

Seu Juquinha acabou de fazer um comentário mal-humorado, como é, aliás, seu costume.

- Não acredito nessa história. Disco voador, nada. Isso é pura cachaçada.

Seu Totó, mais alegre e menos desconfiado, nem faz caso da opinião do outro. Continua contando a sua história, acreditando no testemunho do Bastião Marrom.

- Pois no dia seguinte, de manhãzinha, o chão tava com uma marca redonda e parecia varrido dentro da marca. E não foi só o Bastião que andou vendo. As meninas da dona Bubu também viram a marca... ${ }^{398}$

Ao basear o discurso na modalidade da dúvida, o narrador lança mão do esquema semiótico da imanência, no qual o ser se opõe ao não-ser ${ }^{399}$, e mantém o suspense durante toda a narrativa. Movido pela curiosidade, o leitor acompanha a discussão das personagens sobre a veracidade ou não do fato. Enquanto isso, participa da experiência mágica e das reflexões de Zeca a respeito de índios, escravos e tropeiros, habitantes daquele mesmo lugar, em outras épocas.

O jovem contemporâneo que se dispor a ler esta obra poderá sobrepor à história das culturas narradas a história do tempo de Zeca e de seu fiel amigo, o cachorro Magrão. Afinal, o tempo tem mesmo tantas histórias. Cidades como Gaiola

${ }^{397}$ COELHO, Nelly Novaes. Literatura infantil: teoria, análise, didática. São Paulo, Moderna, 2000, p. 158.

${ }^{398}$ Tantas histórias tem o tempo, pp. 8-9.

${ }^{399}$ GREIMAS, A. J. e COURTÉS, J. Dicionário de semiótica. São Paulo, Cultrix, s/d., p. 488. 
e personagens como as do livro são cada vez mais raras no imenso território deste país.

7.1.24 Cinco anos sem chover. Ilustrações de Paulo Lyra. 14. ed., São Paulo, FTD, 1996. 64 p.

\section{(C) 1983 - Leitor crítico. Realismo crítico}

Escrito em 1983, Cinco anos sem chover é sempre atual ao tratar dos constantes desequilíbrios meteorológicos no País e das conseqüências desses fenômenos na vida das pessoas. O insolúvel problema dos retirantes da seca é abordado sob o ponto de vista de Raimundinho, único filho homem, primogênito, de uma família de três irmãos.

Depois de cinco anos sem chover, em algum ponto não identificado do Nordeste, a população inteira sofre com a falta de água e a escassez de alimentos. O rio está seco, a lavoura devastada, a criação exterminada. Frentes de emergência são organizadas para a construção de açudes, os quais, devido à demanda, logo se transformam em lama e, depois, em barro mais duro.

Nesse contexto, o pai de Raimundinho nem aparece. Sabe-se apenas que ele, após alistar-se como trabalhador numa dessas frentes, sem mais esperança de obter o sustento na região, resolve ir para São Paulo. O dinheiro da passagem havia sido inteirado por meio da venda do jumento, único animal que sobrara, com o auxílio do qual ainda se conseguia buscar um pouco de água, longe que fosse.

A mãe, então, desespera-se, às voltas com três crianças para cuidar. A situação piora dia a dia. Em casa só restam farelos de rapadura. A escola não mais distribui o tão esperado caldo. Em alguns lugares da redondeza, pessoas já comiam cactos, ratos e calangos. Ciça, a irmã mais nova de Raimundinho, não resiste e morre em conseqüência da fome. É quando a mulher decide seguir os passos do marido.

Conceição, a filha do meio, é deixada com Dona Inês, a professora. Pequena do jeito que era, não agüentaria a longa viagem a pé e de carona. Raimundinho e a mãe seguem estrada afora, onde vivenciam as mais diversas experiências. Não são os únicos flagelados. Bandos de retirantes encontram-se pelo caminho. Às vezes, juntam-se em alguma pequena cidade, protestam, pedem esmolas, organizam saques a supermercados. Em outros momentos, dispersam-se. Mãe e filho ora os 
acompanham, ora separam-se. A certa altura, conseguem carona no caminhão de seu Nicolau, que segue direto para São Paulo.

Na cidade grande, se a vida não é fácil, pelo menos não há seca, não falta alimento. A mãe arruma trabalho como lavadeira de roupa e faxineira. Raimundinho carrega sacolas nas feiras. Os minguados recursos permitem que eles vivam em um barraco de favela na periferia. Passado algum tempo, o garoto conhece o marceneiro Beto, com quem começa a aprender o ofício. A sobrevivência já não lhe parece tão pesada, embora ainda o entristeça a saudade da irmã e a falta de notícias do pai. A mãe também parece não pensar em outra coisa. Mantém a idéia fixa de encontrar o marido no meio da multidão. Com esse objetivo, passa a visitar todos os lugares de São Paulo onde é comum a aglomeração de migrantes nordestinos. É assim que o garoto passa a conhecer melhor a cidade em que agora vive.

A busca, no entanto, termina no dia em que chega carta de Dona Inês, dando conta de que o pai havia voltado para o Nordeste. A vida, para ele, não dera certo na cidade grande. A notícia cria novo impasse entre as personagens dessa tão sofrida família, cuja união total o destino e as condições socioeconômicas do País parecem jamais favorecer.

Em todo o percurso narrativo de Cinco anos sem chover, os trechos descritivos, apesar de breves, não se caracterizam como meros panos de fundo para as ações que se desenvolvem. Ao contrário, paisagens e ambientes atuam de modo a influenciar as formas de sentir e de se comportar das personagens. Assim é que, no árido nordestino, a raiva é o sentimento dominante. Dona Inês, a professora, sente raiva. Os vitimados pela seca, em geral, sentem raiva. Os favorecidos das cidades, com receio das invasões de retirantes, sentem raiva. A mãe de Raimundinho sente muita raiva, que se expressa por meio de atitudes e gestos decididos, vigorosos, quase automáticos.

As reações ásperas, no entanto, vão se dissipando durante a viagem rumo ao Sul, à medida que as condições climáticas alteram a natureza em redor.

A chuva passou rápido, mas deixou um arco-íris no céu. $A$ mãe dormiu daí a pouco e Raimundinho reparou que sua cara estava calma. 
O céu foi ficando de um azul muito escuro, conservando faixas mais claras nos espaços entre as nuvens. Raimundinho viu ainda as luzes acesas de um povoado e também dormiu. 400

O discurso cria a sensação cinematográfica. Como em um road movie, em que cada instante da jornada é determinado por acontecimentos imprevisíveis, o leitor acompanha as personagens até a chegada a São Paulo e em suas incursões pela cidade grande. Mãe e filho representam milhares de outros retirantes, cuja sina de terem nascido em localidade inóspita, no interior de um país em que o descaso das autoridades é endêmico, converte-os em quase não-pessoas, praticamente sem identidade e sem nome, como no caso dos pais de Raimundinho.

\subsection{Leitor fluente}

Tendo em vista as etapas por meio das quais se organiza a vida escolar, a fase do leitor fluente vai encontrar o menino e a menina no estágio de desenvolvimento fisiológico a que se dá o nome de puberdade. Por conta das diversas possibilidades de interpretação, julga-se necessário definir melhor o termo. Para tanto, conta-se com o apoio de Blos ${ }^{401}$.

[...] A palavra puberdade é usada aqui para indicar as manifestações físicas da maturação sexual: a pré-puberdade refere-se, por exemplo, ao período que precede imediatamente o desenvolvimento dos caracteres sexuais primários e secundários. A palavra adolescência é usada para indicar os processos psicológicos de adaptação à condição de pubescência. Então, a fase de pré-adolescência, que surge num determinado estado de maturação física, continua a ter um curso independente. Assim, por exemplo, a fase da pré-adolescência pode prolongar-se excessivamente, sem ser afetada pela progressão da maturação física.

Uma vez que só se pode conjeturar a partir de situações específicas, levamse em consideração neste contexto que puberdade e pré-adolescência sejam

\footnotetext{
${ }^{400}$ Cinco anos sem chover, p. 43
}

${ }^{401}$ BLOS, Peter. Adolescência: uma interpretação psicanalítica. 2.ed., São Paulo, Martins Fontes, 1998, p. 6. 
fenômenos inter-relacionados, e que manifestações físicas implicam modificações psíquicas voltadas para o ajuste necessário. Observa-se ainda que, nesse período, a diferença de crescimento entre os sexos é acentuada. As meninas amadurecem mais cedo do que os meninos. Dessa forma, elas voltam-se antes para os relacionamentos afetivos. Embora seja prudente evitar generalizações, também os interesses literários divergem bastante entre os pré-adolescentes femininos e masculinos. Enquanto as primeiras preferem histórias sentimentais, os segundos respondem mais aos argumentos de cunho aventuresco, em que os papéis da turma e da gangue sejam preponderantes. Em ambos os casos, heróis e heroínas que lutam por ideais humanitários e justos exercem forte poder de atração e identificação.

Conforme explica Coelho ${ }^{402}$, nessa fase, a presença do adulto como auxiliar do processo de apreensão dos sentidos do texto não se faz necessária.

Há inclusive uma certa tendência do pré-adolescente a rejeitar o apoio do adulto, pois sente-se alimentado por uma grande força interior, uma quase onipotência. Dá-se uma espécie de "revivescência do egocentrismo"; mentalmente, predominam os interesses ludo-afetivos; e ao mesmo tempo pode-se dar um certo desequilíbrio em sua sintonização com o meio em que vive.

Quanto aos gêneros narrativos que mais chamam atenção dos púberes, encontram-se os contos e as novelas em que as personagens lutam para vencer alguma dificuldade, indiferentemente do tipo de enredo apresentado, que pode ser realista, mítico, lendário, mágico, maravilhoso, policial, cômico, de ficção científica, ou mesmo apresentar uma mescla das características de cada um desses.

Entre livros de Lino de Albergaria destinados ao leitor fluente, encontram-se histórias sentimentais, folclóricas, de suspense, mistério, magia, entre outras sempre adaptadas à situação de crescimento físico e psicológico correspondente ao público a que se destina.

${ }^{402}$ COELHO, Nelly Novaes. Literatura infantil: teoria, análise, didática. São Paulo, Moderna, 2000, p. 38. 


\subsubsection{Tomás e Taís. ${ }^{403}$ Ilustrações Eduardo Albini. São Paulo, Larousse do Brasil. 31 p.}

\section{(C) 2006 - Leitor fluente. Realismo humanitário.}

Tomás e Taís é uma história de encontro: encontro de duas almas sensíveis que se reconhecem e se descobrem parecidas, assim como são parecidos sonoramente dois dissílabos oxítonos terminados pelo fonema constritivo surdo /s/ e iniciados pelo fonema oclusivo surdo /t/.

Tudo começou quando, depois das aulas, Taís resolveu ir a uma exposição de estatuetas de barro. Tomás estava lá, e notou a garota. A oportunidade de abordá-la, no entanto, só ocorreu na saída. Ele primeiro perguntou as horas e, logo em seguida, se ela havia gostado da exposição. Daí a trocarem telefone, demorou o tempo de chegarem à porta do prédio em que ela morava.

Quando o rapaz se foi, apesar de ainda não saber, Taís estava apaixonada. Naquele começo de noite, um último clarão vermelho no céu e as luzes vermelhas dos carros no engarrafamento, vistos lá do alto da janela, nunca tinham sido tão bonitos. Aos sentidos da garota, muito mais acostumada com a vida dos livros e da imaginação, a magia daquele momento era algo totalmente novo.

Por vários dias, eles se reencontraram, passearam e conversaram. Chegaram a caminhar de mãos dadas e a trocar um beijo que, para Taís, significou algo parecido com uma revelação. Durante esse tempo, ela ficou sabendo o quanto Tomás gostava dos peixes do mar e dos cavalos-marinhos. Percebeu então que, em se tratando de animais, preferia as aves, mas que, por meio dos sonhos, bichos do céu podiam ganhar escamas e bichos do mar podiam receber asas.

A narrativa, assumida em primeira pessoa por Taís, apresenta linguagem que mimetiza as confissões de adolescentes em um diário. O recurso cria um efeito de sentido por meio do qual o leitor sente-se íntimo e digno da confiança da personagem. Assim é que se conhecem os sentimentos e pensamentos da garota. Blos $^{404}$ explica que, para o adolescente, o "diário ocupa uma posição intermediária entre o devaneio e o mundo objetal, entre o faz-de-conta e a realidade." Continua o autor:

${ }^{403}$ Texto publicado anteriormente, em versão mais alongada, como parte do livro Um amor de menina. llustrações de Regina Yolanda. Rio de Janeiro, Rio Gráfica / Globo, 1986. 38 p., sob o título "Amor de verdade".

${ }^{404}$ BLOS, Peter. Adolescência: uma interpretação psicanalítica. 2.ed., São Paulo, Martins Fontes, 1998, pp. 128-9. 
[...] o diário ainda tem a mesma função psicológica de preencher o vazio emocional experimentado quando as novas moções pulsionais da puberdade já não podem ser articuladas com velhos objetos e ainda não podem ser articuladas com novos objetos, de modo que a fantasia assume uma função muito importante e essencial. ${ }^{405}$

É realmente nesse momento de transição em que se encontra Taís quando narra sua experiência afetiva. A história de amor por ela vivida não oferece nenhuma garantia de realizar-se efetivamente. Daí que, enquanto vivencia a fase de expectativa, ela escreve memórias e modela bonecos de barro, como formas de expressão das fantasias. Assim, a garota, que antes se interessava apenas pela vida das personagens de ficção, após conhecer Tomás, já pode sonhar com alguém real, feito de carne e osso.

No processo de produção do texto, além do emprego do narrador autodiegético, outros mecanismos discursivos de construção de significado são verificáveis, a começar pela própria sonoridade perceptível no título até os efeitos de oralidade que subjazem toda a obra. Referentemente ao plano do conteúdo, estão presentes símbolos universais extraídos do cotidiano. Um exemplo é o destaque da cor vermelha no céu e nas luzes dos automóveis para representar o despertar da paixão. Outro é a utilização de peixes e aves para significar as polaridades responsáveis pela atração que une Taís e Tomás.

De forma geral, trata-se aqui de obra sensível, por meio da qual o leitor entra em contato com algumas das questões presentes na vida das meninas, quando atingem o estágio inicial da adolescência.

\subsubsection{O livro das estrelas. Ilustrações de Andréa Vilela. Belo Horizonte, Dimensão, 1997. 56 p.}

(c) 1997 - Leitor fluente. Realismo mágico.

A tradição oral de trocar experiências através do contar é recuperada nesta obra, na qual se reúnem oito contos na linha do realismo mágico. A unidade entre as histórias é alinhavada não só pelo conteúdo temático - estrelas, expresso no título -, como também pela presença explícita do mesmo narrador. Por meio do modo

${ }^{405}$ Idem, ibidem, pp. 128-9. 
enunciativo de organização do discurso ${ }^{406}$, esse narrador instaura o ritual de abordagem ${ }^{407}$ típico do contrato de comunicação que busca estabelecer com o leitor. O caráter fundador do texto de abertura justifica sua reprodução na íntegra.

O que você acha das estrelas?

Para mim elas até se parecem com a gente.

Ou tem gente que é meio aparentada com elas.

Eu mesmo, posso jurar que sou.

Pois existe uma estrela que vive trocando olhares e algo mais comigo...

Desconfio que você também deve ter alguma amizade com elas.

Só por isso vou the contar estas histórias que até hoje eram meu segredo.

Você pode achar que é mentira.

Eu digo que não é!

É verdade de estrela... meio diferente das verdades daqui da Terra.

Como se observa, a estratégia é empregada para simular uma monolocução in praesentia dirigida a um ouvinte também presente, à maneira de um adulto contando histórias para uma criança. A utilização do pronome você ocorre também em algumas histórias, de modo a reforçar o simulacro da comunicação oral, bem como o de um interlocutor infantil, conforme o seguinte trecho:

- Claro que vamos! - disse Maricris, que não queria parar de usar seus sapatos de fivelas, suas luvas de renda, suas saias rodadas, suas anáguas engomadas (você já ouviu falar em anágua? Não eram de água, eram de pano!). ${ }^{408}$

Outro recurso que garante o mesmo efeito de sentido é o uso da expressão a gente com o valor de primeira pessoa do plural generalizante, como no segmento:

Existe um ditado que diz que quem vê cara não vê coração. Serve para lembrar à gente que a aparência das pessoas às vezes provoca enganos: no fundo elas não são exatamente o que parecem. ${ }^{409}$

\footnotetext{
${ }^{406}$ CHARAUDEAU, Patrick. Grammaire du sens et de l'expression. Paris, Hachette, 1992, p. 647.

407 Idem, ibidem, p. 638.

${ }^{408}$ O livro das estrelas, p. 11

${ }^{409}$ Ibidem, p. 16.
} 
Que o narrador é adulto, fica-se sabendo apenas no último conto, "Estrela X", quando se esclarece:

O menino desta história sou eu mesmo. Certas pessoas acham que eu sou grande. Dizem até que já tenho barba na cara e a voz grossa. Coitadas. Só porque eu nasci há um tempão atrás, quando nem existia televisão colorida, pensam que eu deixei de ser um menino. ${ }^{410}$

O resgate da milenar arte de contar histórias dá-se ainda pelo gênero das narrativas. Escritas em prosa poética, pertencem à linha do realismo mágico, cujas características são explicadas por Coelho ${ }^{411}$ :

Obras em que as fronteiras entre realidade e imaginário se diluem, fundindo-se as diferentes áreas para dar lugar a uma terceira realidade, em que as possibilidades de vivências são infinitas e imprevisíveis. Situações centradas no cotidiano comum, em que irrompe algo 'estranho', que é visto ou vivido com a maior naturalidade pelas personagens.

Um dos exemplos é o caso de Maria Flávia, Maria Juliana e Maria Cristina, que resolveram ser meninas para sempre. Assim, tomaram um bonde mágico para o céu e se transformaram em constelação, no conto "As Três Marias". Fato semelhante ocorreu com os irmãos Magalhães: Mauro, Marcelo, Maurício e Martinho. Os quatro foram trabalhar num circo. Lá, conheceram o cachorro Maromba. Certa noite, depois do espetáculo, o que tanto desejavam, de fato, aconteceu: viraram "O Cruzeiro do Sul".

Além dessas duas e da última, já citada, outras histórias compõem a obra. São elas: "Estrela da manhã, estrela da tarde", "Estrela do mar", "O asterisco", "A estrela polar", "O cometa e a estrela cadente". Em todas, é o elemento mágico que se apresenta como fator estruturante da narrativa. Na primeira delas ("As Três Marias"), como uma espécie de reforço ao contrato de comunicação estabelecido no ritual de abordagem, verifica-se o uso da expressão "era uma vez", que abre para o

\footnotetext{
${ }^{410}$ Ibidem, p. 54.

${ }^{411}$ COELHO, Nelly Novaes. Literatura infantil: teoria, análise, didática. São Paulo, Moderna, 2000, p. 158.
} 
leitor um horizonte de expectativas em torno de situações que ocorrem fora do nosso espaço/tempo conhecido ou em local vago ou indeterminado na Terra.

Por fim, ideologicamente falando, pode-se traçar um paralelo entre todos os contos e a música Gente, de Caetano Veloso ${ }^{412}$.

Gente olha pro céu / Gente quer saber o um / Gente é o lugar de se perguntar o um / Das estrelas se perguntarem se tantas são / Cada estrela se espanta à própria explosão / Gente é muito bom / Gente deve ser o bom / Tem de se cuidar, de se respeitar o bom / Está certo dizer que estrelas estão no olhar / De alguém que o amor te elegeu pra amar / Marina, Bethânia, Dolores, Renata, Leilinha, Suzana, Dedé / Gente viva brilhando, estrelas na noite / Gente quer comer / Gente quer ser feliz / Gente quer respirar ar pelo nariz / Não, meu nego, não traia nunca essa força, não / Essa força que mora em seu coração / Gente lavando roupa, amassando pão / Gente pobre arrancando a vida com a mão / No coração da mata, gente quer prosseguir / Quer durar, quer crescer, gente quer luzir / Rodrigo, Roberto, Caetano, Moreno, Francisco, Gilberto, João / Gente é pra brilhar, não pra morrer de fome / Gente deste planeta do céu de anil / Gente, não entendo, gente, nada nos viu / Gente, espelho de estrelas, reflexo do esplendor / Se as estrelas são tantas, só mesmo amor / Maurício, Lucila, Gildásio, Ivonete, Agripino, Gracinha, Zezé / Gente, espelho da vida, doce mistério.

Assim como a gente da letra do compositor, as personagens d'O livro das estrelas foram feitas para brilhar.

\subsubsection{O mistério da mochila cor-de-abóbora. Ilustrações de Graça Lima.}

Rio de Janeiro, Ediouro, 1996. 32 p.

() 1996 - Leitor fluente. Realismo lúdico.

Entre os recursos narratológicos descritos pelos teóricos das ciências da linguagem, um dos quais Lino de Albergaria utiliza com relativa freqüência para a criação de diversos efeitos de sentido em suas histórias é o da focalização, tanto por meio de narradores hetero quanto homo ou autodiegéticos.

${ }^{412}$ GENTE. Caetano Veloso. Disponível em: http://www.caetanoveloso.com.br/sec busca obra.php?language=pt BR\&id=51\&sec discogra todas =1. Acesso em: 6 set. 2006. 
Em O mistério da mochila cor-de-abóbora, a focalização é, pois, o elemento discursivo primordial na estruturação do texto, em que várias personagens narram suas próprias experiências. Dessa forma, cada parte do livro, contada sempre por um protagonista diferente, caracteriza-se como uma espécie de crônica isolada, com começo, meio e fim, que pode de ser lida de maneira independente.

No plano geral da obra, seja qual fora a ordem de leitura escolhida, todas as histórias acabam-se entrelaçando, uma vez que determinadas ações e/ou objetos apresentados em cada narrativa funcionam como pontos de intersecção entre os distintos universos diegéticos.

Em virtude de no título do livro aparecer a palavra mistério, não cabe aqui apresentar uma sinopse do enredo. Vale mais a pena convidar o leitor a mergulhar nesse caleidoscópio de histórias.

\subsubsection{Guerra na biblioteca. Ilustrações de Fábio Moraes. 2. ed., São}

Paulo, Atual, 1995. 82 p.

() 1995 - Leitor Fluente. Intriga policialesca.

Pré-adolescentes sentirem-se atraídos por adultos (e vice-versa) é fato cada vez mais freqüentemente observável na sociedade contemporânea. Por conseguinte, o tema é amiúde abordado tanto na literatura para jovens e adultos, como no cinema, no teatro e até na televisão. Certas obras sobre o assunto fizeram bastante sucesso em cada uma dessas áreas e chegaram mesmo a se tornar clássicas.

Em Guerra na biblioteca, Tábata sente-se apaixonada por Agripa, o professor de História, enquanto que Renato, outro aluno da sétima série, irá encantar-se por Lurdinha, a bibliotecária quase vinte anos mais velha do que ele. Mas a paquera também ocorre dentro da mesma faixa de idade, como no caso de Fábio e Bárbara. Em meio às atividades de pesquisa para uma "gincana" sobre a Guerra dos Emboabas, o garoto não medirá conseqüências para conquistar o coração da garota de "cabelos amarelos como ouro" ${ }^{413}$.

Adepto da teoria de que não se entra numa guerra se não for para vencer, Fábio, juntamente com seus colegas, terá de passar por muitas situações perigosas, até compreender que a vitória pode vir por caminhos bem diferentes daqueles que

${ }^{413}$ Guerra na biblioteca, p. 14. 
inicialmente se imaginava, e que nem sempre todos os recursos são lícitos para alcançar o que se deseja. Isso porque a competição proposta pelo professor terá desdobramentos arriscados e, talvez por isso, mais profícuos e emocionantes do que alguns alunos esperavam.

Tudo começou por causa da implicância de dona Etelvina em liberar sem restrições a biblioteca. A bibliotecária da escola preferia atender as crianças pequenas e, justamente naquela ocasião, estava preparando a Semana Vampiro. Depois de alguma negociação com Agripa, acabou permitindo a entrada dos estudantes maiores, com a condição de que viesse um grupo de cada vez. A gincana teria transcorrido sem maiores transtornos, caso Fábio, querendo impressionar Bárbara, não tivesse escrito à caneta vermelha um bilhete para a garota na primeira página de um livro. Após isso, não houve mais nenhuma condição de acordo. A solução que o professor encontrou foi a de levar os alunos para a Biblioteca Pública Luiz de Bessa, localizada em região nobre da cidade de Belo Horizonte, bem perto do colégio, por sinal.

Agripa não tardou a perceber que a saída podia render até mais do que uma simples pesquisa bibliográfica sobre determinado episódio histórico. Já no trajeto, aproveitava a paisagem urbana para falar um pouco sobre a fundação da cidade. $O$ que ele e os jovens não contavam, no entanto, era com as figuras excêntricas que costumavam freqüentar aquele edifício público. Entre essas, estavam "uma velhinha fazendo crochê a um canto e um tipo com cara de bobo, encostado à parede, olhando as pessoas e exibindo um sorriso banguela". ${ }^{414}$ Havia ainda um velho com tapa-olho na cara e jeito de mendigo, e mais algumas pessoas bem estranhas mesmo. Lurdinha, que trabalhava no local, já estava acostumada com alguns deles. Apenas nunca tinha imaginado que tanto ela quanto outros freqüentadores do local podiam estar correndo perigo.

O inesperado, no entanto, ocorreu, justamente durante a realização da gincana, no dia em que Tábata e Bárbara haviam voltado à biblioteca. Fábio e Renato, por motivos diferentes, também estavam lá. De repente, um seqüestro seguido de roubo. O caminhão-biblioteca, antes estacionado à frente do edifício, arranca em disparada pelas ruas de Belo Horizonte, quase causando graves acidentes. Por obra do acaso, naquele exato momento, Agripa e Geraldo (professor

${ }^{414}$ Ibidem, p. 19. 
de Educação Física) faziam Cooper pelas redondezas. Bárbara e Lurdinha haviam desaparecido. Começa então uma verdadeira corrida para descobrir o paradeiro das duas.

A partir de uma pista incompleta, deixada pela bibliotecária na tela do computador, dois professores e três estudantes, apertados dentro do Fusca amarelo de Geraldo, saem na velocidade máxima que o pequeno carro podia alcançar. Por estradas e cidades no interior de Minas Gerais, percorrem exatamente os mesmos locais em que se havia travado, no passado, a Guerra dos Emboabas. A narrativa ganha, então, ritmo de aventura, na qual não faltam peripécias, imprevistos, pistas falsas, sinais reveladores e algumas surpresas. Para salvar Bárbara e Lurdinha contribuem inclusive um par de gnomos, muito parecidos.

Embora inserida na linha detetivesca tradicional dos romances policiais, a qual tem na ação e no suspense seus focos privilegiados, Guerra na biblioteca é uma obra em que as questões relativas ao desenvolvimento psicológico das personagens em nenhum momento são deixadas de lado. Tanto é que, assim como Fábio revê sua opinião sobre ganhar sempre, também Renato e Tábata percebem a necessidade de refletir a respeito de suas carências afetivas. Ao final do enredo, o leitor atento terá percebido que, além de acompanhar o desenrolar vertiginoso dos fatos e de torcer pela resolução de um crime, envolveu-se, de forma sutil, em um entrelaçamento de histórias de amor e recebeu informações sobre a História de Minas Gerais.

\subsubsection{Um anjo no jardim. Ilustrações de Paulo Tenente. 12. imp., São}

Paulo, Moderna, 2002. 48 p.

\section{(C) 1993 - Leitor fluente. Realismo lúdico e mágico}

Na primeira edição de Um anjo no jardim, na página reservado ao autor e sua obra, Isalino de Albergaria diz:

Escrever é um ato fascinante. Tanto, que eu comecei a olhar para dentro do que eu escrevia. E quis desmontar os textos, como alguém desmonta um relógio para conhecer seus mecanismos. Desmontei e reconstruí história, examinei seus avessos. Embaralhei partes. Brinquei com as ilustrações. Apaguei um texto com outro texto. Procurei reescrever uma história, usando o método dos espelhos: invertendo, refletindo. Em 
seguida, resolvi fazer uma história que respirasse dentro dos espaços vazios de uma outra.

O resultado desse processo criativo pode ser verificado na obras em que o autor deixa de lado formas narrativas convencionais e lança mão de diferentes estratégias narratológicas, de modo a experimentar estruturas textuais não só inovadoras sob o aspecto formal, mas também ricas sob o ponto de vista das possibilidades semânticas. Uma das técnicas reiteradamente utilizadas é a da exploração dos diversos pontos de vista a partir dos quais uma determinada história pode ser contada.

Em Um anjo no jardim, o recurso consiste em narrar o encontro entre Guga e Rita, ambos recém-saídos da fase de latência, a partir da focalização de cada um deles, instaurando-os inclusive como narradores autodiegéticos de suas próprias experiências. O livro está organizado em duas partes: "A vizinha do Guga" e "O vizinha da Rita". Na primeira, o menino conta como conheceu, pré-julgou, brigou e, finalmente, namorou a menina. Na segunda, é a menina que conta como conheceu, pré-julgou, brigou e, finalmente, namorou o menino.

O tom de oralidade, a fluência e o humor são as marcas mais evidentes deste texto, em cujo conteúdo predominantemente realista irrompem manifestações do elemento mágico. Tanto Guga quanto Rita, cada um a seu modo, desabafam suas dúvidas e inseguranças com um anjo conselheiro e protetor, que lhes responde em pensamento.

Para os leitores que se encontram entre os $10-11$ anos, conforme esclarece Coelho ${ }^{415}$, ainda "o maravilhoso, o mágico [...] continuam sendo grandes atrações. $E$ principalmente a presença desse maravilhoso, mágico, fantástico ou absurdo como participante natural da vida cotidiana e real." É também nessa faixa etária, continua a professora, que se abre "espaço para o amor".

${ }^{415}$ COELHO, Nelly Novaes. Literatura infantil: teoria, análise, diática. São Paulo, Moderna, 2000, p. 39. 


\subsubsection{A mão do encantado. Ilustrações de Marco Cena. Porto Alegre,} Mercado Aberto, 1987. 40 p.

(c) 1987 - Leitor fluente. Realismo mágico.

Em 1987, telefonia celular e internet eram ainda apenas promessas em um mundo que começava a se globalizar. Os computadores pessoais, bastante limitados e extremamente caros, estavam sendo comercializados havia poucos anos. Mas já era possível imaginar a que viria a revolução tecnológica, isto é, que mudanças de paradigmas trariam para a sociedade a chamada era da informação e do conhecimento. É nesse momento, quando a maioria dos olhares voltava-se para o futuro, que Lino de Albergaria busca preservar um pouco das lendas originárias do Brasil rural.

A mão do encantado é a história do menino da roça que mal percebe o quanto já está crescido. Tão distante da civilização vive Helinho, que mal se observam em seu comportamento sinais de influência dos meios de comunicação. Como ilustra o trecho abaixo, ele nota pela primeira vez que a infância havia ficado para trás ao espelhar-se na garota da fazenda vizinha.

E eu fui pro meu [quarto]. [...] pensando que Alice ia ficando uma mocinha e só hoje reparei. E que se Alice tava deixando de ser criança, eu também tava... ${ }^{416}$

Mas a certeza mesmo a respeito de seu desenvolvimento somente virá por meio do diálogo com o pai.

— Ainda não tinha reparado... - ele começou assim.

— No que, pai?

- Que você está deixando de ser menino...

Pensei pra mim que eu também tinha custado a perceber. Agora ele falando, era ainda mais certo que era assim... ${ }^{417}$

Tanto era assim, que Helinho demonstra estar mais amadurecido do que alguns adultos da história, como seu tio Onofre, por exemplo, que jamais assumira a paternidade da filha, ou mesmo sua mãe Jesuína, que se recusava a benzer a

\footnotetext{
${ }^{416}$ A mão do encantado, p. 13

${ }^{417}$ Ibidem, pp. 26-7.
} 
recém-nascida Neném, por conta de uma desavença no passado com outra mulher. O fato de o garoto estar entrando na pré-adolescência é representado também pela vontade que ele sente de fumar cachimbo. O fumo, no entanto, desempenha no enredo uma função mais simbólica do que propriamente ato de afirmação adolescente. Embora esse significado esteja presente, o cachimbo promove o elo com o mundo sobrenatural. Cada vez que o acende, Helinho mantém contato com o Saci, e descobre uma herança: assim como a mãe, ele também tinha "parte com o encantado" 418.

Outros fatores ainda dão conta do crescimento do garoto. Ele já é capaz de comparar a generosidade otimista da comadre Laurinda (a caseira), com o pessimismo rancoroso da mãe. Já sente atração pela beleza de Alice. Já sabe fazer, em suas orações, pedidos altruístas. Já tem coragem de acreditar em si mesmo e de se arriscar para fazer o bem. E, até mesmo, de abandonar o hábito de fumar cachimbo, ao compreender que não precisa mais dele.

É a própria voz de Helinho que se ouve no processo de leitura da obra. Narrado em primeira pessoa, o texto recupera características de linguagem e fenômenos culturais do sertão brasileiro, hoje quase esquecidos. Substantivos como tulha, catre e banzo; o verbo pitar preferencialmente a fumar, aprumar no lugar de melhorar, apear em vez de descer ou saltar, além de expressões como evém e ter parte com relembram o falar caipira. Crenças populares, representadas pelo poder curativo de Jesuína, a benzedeira respeitada e temida ao mesmo tempo; superstições votivas ante o testemunhar de uma estrela cadente, entre outras manifestações, resgatam para o leitor contemporâneo a ingenuidade de um estilo de vida fadado a desaparecer.

Nesse sentido histórico de lançar luzes sobre as raízes da identidade de um povo, A mão do encantado é um livro sempre atual. Especialmente, por demonstrar que comportamento ético e solidário não está relacionado com faixa etária.

${ }^{418}$ Ibidem, p. 15. 


\subsubsection{Um amor de menino. Ilustrações de Regina Yolanda. Rio de Janeiro, Rio Gráfica / Globo, 1986. 24 p.}

(C) 1986 - Leitor fluente. Realismo humanitário e lúdico.

Gramaticalmente, o título da obra apresenta ambigüidade semântica. A locução adjetiva Um amor de menino tanto pode ser compreendida como um menino que é um amor, quanto um amor típico, próprio (característico de) menino. As duas narrativas que compõem a obra aludem a esse segundo sentido. Porém, nada impede que o leitor (ou a leitora) atribua ao protagonista de cada uma delas o outro significado da expressão.

A primeira história, que dá nome ao livro, é narrada por Pedro. O garoto conta como foi o primeiro carnaval que ele e seu irmão mais novo, Carlito, passaram na praia. Haveria matinês em diversos lugares e a empolgação dos dois já começava com a escolha da fantasia. Os pais queriam que eles usassem trajes de havaianos, mas os filhos queriam porque queriam vestir-se de marinheiros. Venceram os filhos.

No baile, em meio à folia, alguém arrancou o chapéu de Pedro. Fora um palhaço ruivo, que logo se perdeu na multidão. O garoto ainda tentou correr atrás. Chegou a confundir o ladrão com vários outros palhaços foliões. Mas o concurso de fantasias já havia começado e, quando deu por si, estava embevecido com a sereia de olhos verdes que desfilava no palco. Do encantamento até a recuperação do chapéu, muitos lances ainda iriam ocorrer nesse carnaval de Pedro.

Janaína, o segundo conto, é Rodrigo quem narra. Ao contrário do anterior, em que fatos externos orientam as ações da personagem, este é uma espécie de confissão em voz alta dos desequilíbrios emocionais que o ciúme causa, especialmente a alguém tão jovem. Trata-se daquele tipo de experiência interior, pessoal e intransferível, pela qual nenhuma opinião alheia ajuda alguém a passar. Desabafa o garoto:

Mas acho que eu fiz foi bem em cortar o papo dela [ao telefone] querendo arrego... Pois tá assim de menina por aí, como falou o Ricardo, que é meu irmão, e muito mais experiente nesse assunto de namorada. $O$ Ricardo já teve três namoradas. A Janaína foi minha primeira e até hoje única. ${ }^{419}$

${ }^{419}$ Um amor de menino, p. 19. 
Quanto mais refletia, mais cresciam as inseguranças, e a certeza de Rodrigo sobre se havia feito bem ou não de "cortar o papo" ficava cada vez mais abalada. Sair desse estado exigirá dele a tomada nada fácil de algumas decisões.

Pedro e Rodrigo atravessam o período de passagem da puberdade para a adolescência inicial. Uma das características dessa fase é a dissolução dos objetos de amor incestuosos. "Tanto o menino como a menina voltam-se agora, com maior vigor, para o objeto extra familiar libidinoso", esclarece Blos. ${ }^{420}$ Nesse momento, a necessidade que o púbere tem de ser amado, gradualmente, funde-se com a necessidade de amar, como a que sentem os protagonistas dessas histórias.

\subsection{Leitor-em-processo}

Em geral, a criança atinge o estágio do leitor-em-processo quando se encontra no período a que os psicanalistas dão o nome de latência. É a fase do aprendizado formal e o momento no qual a vida em grupo passa a chamar mais atenção. Embora o ambiente familiar ainda a exerça forte influência, o cotidiano da vida escolar contribui cada vez mais para a formação da competência social, intelectual e motora. Desenvolvem-se muito aceleradamente nessa etapa novas capacidades físicas e mentais, tornando possível a busca organizada do aprendizado.

A preocupação da criança com os conteúdos que lhe são passados nas aulas ocupa pouco a pouco em sua mente o lugar da imaginação. Como resultado, há uma separação crescente entre pensamento racional e fantasia. Os brinquedos infantis são paulatinamente trocados por jogos que estimulam desafios e, até mesmo, por livros e cadernos. Tendo adquirido certa prática no emprego dos mecanismos da leitura, ela manifesta também sensível aumento da capacidade de expressão verbal e torna-se mais exigente com relação ao desenvolvimento do intelecto. Em geral, bombardeia os adultos com uma série interminável de perguntas, na tentativa de organizar seu pensamento lógico. Trata-se da conhecida fase do "por que".

${ }^{420}$ BLOS, Peter. Adolescência: uma interpretação psicanalítica. 2.ed., São Paulo, Martins Fontes, 1998, p.102. 
Como conseqüência desse processo, nota-se clara distinção entre o comportamento que o menino ou a menina apresentam em público daquele que demonstram no mundo privado. Por meio dessa diferenciação, a criança apreende facilmente as instituições sociais normativas - educação, religiosidade e recreação - como modelos de valor que promovem interação entre grupos sociais. Uma vez mais bem integrada nos ambientes fora do lar, ela ganha senso de auto-estima, por conta das realizações e habilidades que conquistam aprovação objetiva por parte daqueles que a rodeiam. Com isso, nota-se em suas atitudes maior estabilidade de afetos e estados de espírito. Blos ${ }^{421}$ resume as realizações da criança durante o período de latência por meio da seguinte lista:

[...] a inteligência deve ter se desenvolvido por meio de uma delineação nítida entre o processo de pensamento primário e secundário, e pelo emprego do julgamento, generalização e lógica; o entendimento social, a empatia e os sentimentos altruístas devem ter adquirido considerável estabilidade; a estatura física deve permitir independência e domínio do ambiente; as funções do ego devem ter adquirido uma capacidade de resistência cada vez maior à regressão e desintegração sob o impacto de situações críticas menores, isto é, cotidianas; a capacidade de sintetização do ego deve ter-se tornado efetiva e complexa e, finalmente, o ego deve ser capaz de defender sua integridade com uma ajuda cada vez menor do mundo exterior.

Portanto, a literatura voltada para o leitor-em-processo deve estar à altura dos questionamentos típicos dessa fase. Por meio de suas obras voltadas para esse estágio de aprendizagem, Lino de Albergaria lança importantes desafios à inteligência do público ao qual de destina, não só do ponto de vista do conteúdo, mas também da estrutura narrativa.

${ }^{421}$ BLOS, Peter. Adolescência: uma interpretação psicanalítica. 2.ed., São Paulo, Martins Fontes, 1998, p. 77. 


\subsection{1 Álbum de família. ${ }^{422}$ llustrações de Ana Maria Moura. São Paulo,} Edições SM, 2005. 60 p.

() 2005 - Leitor-em-processo. Realismo cotidiano.

Faz parte do senso comum a noção de que os opostos se atraem. Com relação ao tempo, é essa a idéia que está na base do sentido de Álbum de família. Voltado para o leitor-em-processo, o texto aborda o encontro entre o extremo de gerações.

Na casa de Manuela, no Rio de Janeiro, certo dia chegam um baú, uma malasanfona e uma caixa redonda. Era a bagagem de dona Maria Tercília, que vinha para morar. De tudo que a bisavó trouxera, a menina gostou mais dos chapéus.

[...] Tinha chapéu amassado, furado, chapéu de fita, chapéu enfeitado de flor e um chapéu lindo, com passarinho, um alfinete e um véu de tule para cobrir o rosto. ${ }^{423}$

A identificação da bisneta com a idosa senhora de cabelos azuis deu-se de imediato. As duas conversavam muito sobre a vida, os hábitos e a moda nos velhos tempos da antiga capital do Brasil. Incomodado mesmo com a nova presença ficou Antonio, o pai de Manuela. Reclamava ele com a esposa que dona Maria Tercília não fazia nada de útil.

Situação inversa sucedeu quando o avô de Antonio mudou-se para a mesma casa. A partir de então, Marli passou a se queixar, dizendo que seu Neném era muito teimoso. Manuela, no entanto, rapidamente afeiçoou-se também ao bisavô, que, à noite, Ihe contava histórias.

Foi assim que, com a presença dos dois novos hóspedes, o cotidiano daquele lar começou a se transformar. O que faltava de compreensão entre os adultos, sobejava em carinho e divertimento entre os velhos e a criança. Só mesmo uma oportunidade de os três ficarem sozinhos criaria as condições para a resolução dos conflitos, da melhor maneira para todos.

\footnotetext{
${ }^{422}$ Texto publicado anteriormente, em versão mais alongada, como parte do livro Um amor de menina. llustrações de Regina Yolanda. Rio de Janeiro, Rio Gráfica / Globo, 1986. 38 p., sob o título "A nossa festa".

${ }^{423}$ Álbum de família, p. 10.
} 


\subsubsection{A família invisível. Ilustrações de Denise Rochael. São Paulo,} Saraiva, 2005. 88 p.

\section{(C) 2004 - Leitor-em-processo. Realismo mágico}

Segundo Klein ${ }^{424}$, a criança pequena experimenta muito cedo sensações de ansiedade e sentimentos de culpa decorrentes de tendências agressivas relacionadas com o conflito edipiano. Para Bloss ${ }^{425}$, é por meio de atividades lúdicas carregadas de fantasia e de significação psicológica que essa ansiedade pode ser regulada e, até mesmo, controlada no período da primeira infância. A fantasia característica dessa fase, diz o autor, ajuda a estabelecer a diferenciação entre realidade interior e exterior, entre o eu e o não-eu, e a promover a redução da dependência e a crescente separação entre a criança e a mãe.

Psicologicamente falando, sabe-se que as crianças expressam fantasias, desejos e experiências reais de modo simbólico, por meio de uma linguagem que se aproxima daquela própria dos sonhos e que se concretiza através de brincadeiras e jogos. Entre esses, o faz-de-conta é um exemplo que, muito freqüentemente, se manifesta na criação de amigos invisíveis, com os quais as crianças estabelecem variadas e importantes formas de relacionamento.

É na necessidade de individuação e na capacidade de imaginação infantil que se encontra a base de construção do sentido de $A$ família invisível. Num dia em que o vento impetuoso abriu a porta do armário e fez as camisas nos cabides começarem a dançar, Renato encontrou um minipalhaço morando dentro de seu guarda-roupa. Não demorou muito e outras pessoas em miniatura começaram a aparecer. O garoto logo constatou tratar-se de uma família. Um dos filhos tinha fugido de casa, com a intenção de trabalhar no circo. A mãe, Mariquinha, o pai, Florivado, e o irmão, Bocó Sem-Sorte, tentavam dissuadi-lo da idéia e levá-lo de volta para casa. Havia também o Bebelino, irmãozinho mais novo, que, embora ainda fosse um bebê de colo, já falava muito bem.

Mas onde haveria um circo em dimensão proporcional à daquelas criaturas, no qual Polidoro (era assim que o palhaço se chamava) pudesse trabalhar? É aí que Marina, a vizinha da casa em frente, entra na história. Certo dia, a menina bateu à

${ }^{424}$ KLEIN, Melanie. A psicanálise de crianças. Trad. Liana Pinto Chaves. Rio de Janeiro, Imago, 1997, p. 15.

${ }^{425}$ BLOS, Peter. Adolescência: uma interpretação psicanalítica. 2.ed., São Paulo, Martins Fontes, 1998, p. 9. 
porta de Renato, em busca do palhaço. Como saberia ela da existência de Polidoro? Por que e para que o estaria procurando? Só mesmo as crianças, cúmplices em suas fantasias, para entenderem o que se passava naquelas duas casas, já que os adultos e nem mesmo o cachorro podiam perceber tanta movimentação, tanto intercâmbio de brinquedos, sonhos e informações.

Os pais de Renato, por exemplo, nem sequer notavam que o filho não comia quase nada no jantar. Imagine-se para uma criança deparar-se à mesa com pratos como bife de fígado, língua, dobradinha, chouriço, sopa de miolos, jiló...! Outra forma peculiar de a criança afirmar o seu processo de distinção do outro se dá por meio da relação com a comida. Segundo Diana e Mário Corso ${ }^{426}$, a recusa em aceitar o que Ihe servem é um movimento de independência importante, é "descobrir que é possível discordar do adulto, que ele não é tão poderoso nem onipresente, como se acreditava".

Os autores tratam do assunto ao analisarem a versão dos irmãos Grimm para o conto João e Maria. Ao comentarem o episódio em que João engana a bruxa, mostrando-Ihe o osso em vez do dedo, quando a mulher vinha saber se o menino já havia engordado, dizem eles: "A tarefa é dar-se conta do quanto se é independente do desejo da mãe: não adianta a bruxa querer lhe empurrar comida, fazendo de João um porquinho, ele lhe responderá com sua magreza". ${ }^{427}$ Atenta-se para o fato de que se deve levar em consideração a bruxa como a face negativa da mãe, na visão da criança.

Significativas são, portanto, as referências a essa obra clássica em $A$ família invisível. A primeira delas ocorre quando a mãe larga o filho sozinho à porta da casa de Marina:

Lá se foi ela, pisando com o barulho de sempre. Renato se lembrou da história de Joãozinho e Maria abandonados na floresta escura. Sentiu que Sônia tinha acabado de fazer o mesmo com ele. ${ }^{428}$

A segunda dá-se quando, fugindo do cachorro, Renato encontra-se sozinho dentro da casa da vizinha.

${ }^{426}$ CORSO, Diana Lichtenstein; CORSO Mário. Fadas no divã: psicanálise nas histórias infantis. Porto Alegre, Artmed, 2006, p. 45.

${ }^{427}$ Idem, ibidem, p. 45.

${ }^{428}$ A família invisível, p. 37. 
Tinha uma escada diante dele, com degraus de madeira escura. As janelas estavam fechadas. A casa toda era muito escura. Ele só pensava na floresta em que Joãozinho e Maria se perderam. ${ }^{429}$

A intertextualidade, neste caso, confirma a interpretação a respeito da semelhança entre o material simbólico presente no tradicional conto de fadas João e Maria e em A família invisível, narrativa contemporânea, na qual as fronteiras entre realidade e imaginário se diluem.

\subsubsection{A boneca e o Saci. Ilustrações de Andréa Vilela. Belo Horizonte, Dimensão, 1998. 32 p. \\ (C) 1998 - Leitor-em-processo. Realismo mágico, histórico e folclórico.}

Além de encontrar-se dentro do contexto geral da literatura infantil, $A$ boneca e o Saci enquadra-se num gênero bastante difundido entre o público adulto, especialmente no mercado editorial brasileiro, mas pouco explorado no universo dos jovens leitores, que é o da biografia. O livro narra, de forma romanceada e ilustrada, fragmentos da história pessoal e profissional de Monteiro Lobato, intelectual atuante em vários setores da vida social, cultural, política e econômica do Brasil, que se notabilizou como um dos maiores autores para crianças e jovens do País, ao criar a série conhecida como o Sítio do pica-pau amarelo.

No texto, estão presentes, além de Emília e do Saci Pererê, referências aos livros escritos, editados e publicados por Monteiro Lobato; à luta do escritor em favor da produção de ferro e petróleo no Brasil, que remete à obra O poço do Visconde; a Dom Quixote de La Mancha, personagem de Miguel de Cervantes, do qual Lobato se apropria para escrever D. Quixote das crianças, e a outros elementos da série. Para apresentar fatos da vida e obra do ilustre brasileiro, Lino de Albergaria instaura como narrador-personagem, em primeira pessoa, o próprio Saci Pererê, que, depois de se apresentar como "menino negrinho, que gosta de noite bem escura e de viver no mato, onde há umas plantas chamadas taquaras" ${ }^{430}$, visita a Fazenda São José

\footnotetext{
429 Ibidem, p. 40.

${ }^{430}$ A boneca e o Saci, p. 5.
} 
do Buquira, onde viveu o biografado. Lá, encontra-se com Emília, com quem conversa sobre o renomado escritor.

É a partir do diálogo entre as duas personagens que se constrói a narrativa histórica, que apresenta também um caráter literário ficcional. Como exemplo, citase o fato de as personagens poderem viajar no tempo e até entrarem no sonho de Monteiro Lobato, utilizando, para isso, o famoso pó mágico de pirlimpimpim. Além disso, suas características e formas de comportamento são mantidas, como podem ser verificadas no trecho em que o Saci e a boneca se encontram:

- Quem é você? - eu pergunto.

— Sou Emília, a Marquesa de Rabicó!

Aquela coisinha era muito metida. Uma boneca feita em casa, com retalhos de pano barato. Marquesa, pois sim. Fiz de conta que acreditava.

- Muito prazer, senhora Marquesa. Saci Pererê, seu criado e às suas ordens.

Ela não percebeu minha gozação e continuou exibindo aquele ar de rainha. ${ }^{431}$

\subsubsection{Amanhã chega o sol. Ilustrações de Marilda Castanha. Rio de Janeiro, Ao Livro Técnico, 1997. 16 p.}

(C) 1997 - Leitor-em-processo. Realismo humanitário.

A descoberta do sentimento fora do âmbito familiar ocorre cada vez mais cedo, estimulada especialmente pelos meios de comunicação de massa. Sob esse aspecto, a literatura infantil auxilia a criança a compreender melhor o que se passa dentro de si. Em Amanhã chega o sol, a experiência de Flávia pode revelar ao leitor ou leitora alguns dos princípios que regem o processo de atração entre as pessoas.

Tudo começa quando, no primeiro dia de férias na praia, uma chuva inesperada e contínua vem atrapalhar os planos da família. Os pais e os irmãos entretêm-se com baralho. Depois de esgotar as leituras e as palavras cruzadas que tinha para fazer, a menina espia pela vidraça e, na janela da casa em frente, vê um garoto de cabelos espetados. Olhares se cruzam. No dia seguinte, o acaso providencia o encontro. A conversa e a troca de revistas revelam a identificação.

${ }^{431}$ Ibidem, p. 13. 
Novo encontro é marcado, na certeza de que o sol não os desapontará. Finalmente, as férias prometiam diversão.

\subsubsection{Violetas e alfazema. Ilustrações de Lúcia Hiratuka. Belo Horizonte,} Lê, 1995. 32 p.

(C) 1995 - Leitor-em-processo. Realismo humanitário.

A narradora de Violetas e alfazema, embora não se saiba que idade tenha, relata experiências de quando se encontrava na fase de "latência". Trata-se do estágio de desenvolvimento psicológico correspondente aos anos entre a segunda infância e a adolescência. É o momento em que a vida imaginativa torna-se limitada e as brincadeiras são mais adaptadas à realidade, em consonância com a repressão intensa da fantasia. Segundo Klein ${ }^{432}$, nesse período, "o ideal de ego da criança é a criança bem-comportada, 'boazinha', que satisfaz os pais e os professores". Ressalta-se aí a fundamental importância do relacionamento com os adultos e da sanção daqueles em posição de autoridade para o fortalecimento do ego, que começa então a atuar em concordância com o superego.

Essa talvez fosse a principal razão que fazia Maria Rita gostar tanto de conviver com Rita, sua avó para lá de moderna. É a menina quem conta:

Mãe do meu pai, não tinha essa de ser chamada de vó. Era Rita mesmo, para meu pai, minha mãe, para mim e todos os netos. Fazia ioga, tinha mania de cristais e de incensos, era viúva e de vez em quando arrumava uns namorados. ${ }^{433}$

É com essa avó que Maria Rita irá criar referências marcantes para seu comportamento na puberdade, na adolescência e, quem sabe, até na vida adulta. $O$ lado feminino cuidadoso, de manter o ambiente de uma casa "macia", em alto-astral e aconchegante; o conhecimento meio mágico sobre o poder das flores, dos perfumes, dos incensos e dos objetos simbólicos; o sentimento afetuoso pelos gatos de estimação, em vez do medo daqueles olhos "abertos, luzindo dentro da noite",

${ }^{432}$ KLEIN, Melanie. A psicanálise de crianças. Trad. Liana Pinto Chaves. Rio de Janeiro, Imago, 1997, p. 200.

${ }^{433}$ Violetas e alfazema, p. 5. 
tudo isso havia ficado impregnado na personalidade da menina. Mesmo depois da partida definitiva de Rita.

Com o pai, na volta do cemitério, Maria Rita aprendeu a chorar em silêncio, muda. E confessa:

[...] Mas não foi por imitação que comecei a chorar igual ao meu pai. Aconteceu e eu choro assim. Sozinha, no escuro [...]. Toda vez que lembro da Rita. Aquela mulher macia e cheirosa que eu nunca chamei de avó. Nem ela nunca me chamou de neta. Penso que a gente ia ficando cada vez mais igual no trato. Uma mulher e outra mulher. ${ }^{434}$

Mesmo que não admitam, sabe-se que é, sim, por imitação que as crianças desenvolvem hábitos e padrões de conduta, especialmente no período de latência, caracterizado, no dizer de Blos ${ }^{435}$, como aquele "intermediário entre o florescimento da sexualidade infantil e a sexualidade genital pubescente", e no qual o simples fato de manter um segredo, com relação a qualquer coisa, é fonte de prazer e excitação. ${ }^{436}$ Isso explica porque Maria Rita chora escondida e "rouba" do álbum de família a foto em que aparece sentada no colo da avó.

Além enfocar de modo sensível e poético o desenvolvimento do superego infantil feminino, Violetas e alfazema é a história sobre como uma menina sente a passagem do tempo, por meio dos objetos e das circunstâncias em sua volta. Conforme ela mesma observa, o "sofá e o tapete da sala já perderam o cheiro de novo", "o carro precisa ir à oficina" 437: uma forma inocente, porém sábia, de constatar a impermanência das coisas; uma forma de entender e aceitar a morte dos entes queridos.

${ }^{434}$ Ibidem, p 16.

${ }^{435}$ BLOS, Peter. Adolescência: uma interpretação psicanalítica. 2.ed., São Paulo, Martins Fontes, 1998, p. 9.

${ }^{436}$ Idem, ilbidem, p.79.

${ }^{437}$ Violetas e alfazema, p. 28. 


\subsubsection{A música lá de casa. Ilustrações de Pierre Trabbold. São Paulo,} Edições Loyola, 1994. 24 p.

(C) 1994 - Leitor-em-processo. Realismo cotidiano.

Talvez nunca antes na História, as pessoas tenham tido tão pouco tempo para se adaptarem a um conjunto de avanços tecnológicos como o que se deu entre a última década do século $X X$ e a primeira do século XXI. No campo do lazer e do entretenimento, houve uma verdadeira revolução, especialmente nos lares dos habitantes do mundo ocidental. A popularização dos computadores pessoais entre as famílias de classe média rapidamente transformou os meios pelos quais se produz imagens, se escuta rádio, se ouve música, se assiste à TV. E o processo evolutivo está longe de dar sinais de esgotamento.

Em meio a esse vertiginoso progresso, fomentador de formas de divertimento solitárias e individuais, Lino de Albergaria escreve um texto no qual resgata o hábito de tocar um instrumento e de cantar como atividade lúdica que, além de estimular a criatividade, contribui para a aproximação e união entre as pessoas. Em A música lá de casa, narra-se a história de uma família que, por conta de um complicado defeito ocorrido no aparelho de som, redescobre o talento musical há muito adormecido.

\subsubsection{O dia das mães. Ilustrações de Carlos Eduardo Colabone. São Paulo, Ed. do Brasil, 1991. 96 p. \\ (ㄷ) 1991 - Leitor-em-processo. Realismo humanitário.}

As personagens de $O$ dia das mães cursam o ciclo básico do ensino fundamental. Embora não se explicite, tudo indica que estejam na primeira ou segunda série, dadas as atividades educacionais que desempenham sob a orientação da professora Isabel. A história gira em torno dos preparativos para a festa do dia das mães que haverá na escola. Um grupo de três meninos e outro de três meninas atuam de modo bastante representativo do período de desenvolvimento infantil ao qual os psicanalistas chamam de latência. Conforme explica Blos, nessa fase, "o aprendizado formal e a vida em grupo passam a chamar 
mais atenção da criança; a consciência social a leva para além dos limites da família, enquanto a posição central da família continua a exercer sua influência". ${ }^{438}$

Sob esse aspecto, o que se acompanha no enredo é o modo como se dá o processo de socialização de Júlio, Marino e Cláudio, por um lado, e de Ana Lia, Beatriz e Rogéria, de outro, a partir das influências diferentes que recebem no lar, por meio do convívio com os pais e irmãos. A separação nítida entre masculino e feminino é comportamento padrão nesse estágio, que irá durar até a préadolescência. De modo a explorar essa característica, o autor também cinde o universo diegético, fazendo incidir o foco narrativo ora no mundo dos meninos ora no mundo das meninas. Isso, sem apartá-los completamente, pois ao mesmo tempo em que se contrapõem os agrupamentos também se inter-relacionam de forma especular, isto é, servindo de parâmetro comportamental um para o outro. Além do mais, solidarizam-se com relação às implicações do mundo dos adultos.

No decorrer da narrativa, o leitor conhece, portanto, as particularidades de cada criança: Júlio não quer mais ser tratado como menino pequeno; Rogéria sente falta da atenção da mãe; Cláudio gosta de ler e questiona as contradições da vida; Beatriz tem mãe estressada; Marino sofre calado pela perda da mãe num acidente de automóvel, e Ana Lia tem de lidar com o próprio ciúme, por causa da irmã menor. Evidentemente, as questões individuais vão se refletir na vida em comunidade e gerar problemas.

Os anos entre a primeira infância e a adolescência são da maior importância na preparação para a adolescência, porque esse período estabelece novos caminhos para a satisfação e para o domínio do ambiente, por meio do desenvolvimento da competência social e de novas capacidades físicas e mentais. De modo geral, ações singelas e conflitos que, aos olhos adultos, podem parecer banais ganham dimensões significativas para as crianças dessa história. Mas são fatos ordinários do cotidiano que promovem o crescimento psíquico, pois propiciam a reflexão sobre importantes conceitos para a evolução do ser humano, tais como solidariedade, confiança, coragem, valentia, medo, afeto, dedicação, entre tantos outros.

${ }^{438}$ BLOS, Peter. Adolescência: uma interpretação psicanalítica. 2.ed., São Paulo, Martins Fontes, 1998, p.10. 


\subsubsection{Histórias que se apagam. Ilustrações de Eva Furnari. São Paulo, Melhoramentos, 1991. $42 \mathrm{p}$. \\ (C) 1991 - Leitor-em-processo. Jogo lingüístico com elementos do maravilhoso folclórico.}

Histórias que se apagam faz parte de uma trilogia de obras (as outras duas são: Histórias espelhadas e Histórias embaralhadas) em cujo enredo expressões populares típicas do Brasil se relacionam de alguma maneira, na maioria das vezes em situações completamente inusitadas. Além disso, o desenvolvimento do mesmo tema por meio de diferentes formas de construção textual cria o efeito narrativo enunciado no título, de caráter nitidamente metalingüístico.

O livro Histórias que se apagam é composto por duas narrativas - "Água do rio" e "Água do mar" - de estrutura similar. Porém, a presença de personagens com nomes e características diferentes faz com que as histórias se anulem ou desmintam-se mutuamente.

Na primeira, Perequeté morava na beira do rio e o que ele mais queria era virar marinheiro. Decidido, solta seu barco na correnteza das águas doces. Mas, como não sabia "com quantos paus se faz uma canoa" ${ }^{439}$, a embarcação acaba afundando. Nesse momento, é ajudado por Tico de Gente, Espirro de Gente e Fiapo de Gente a construir um novo barco. A partir de então, os quatro irão viver uma aventura rio abaixo, rumo ao mar. No caminho, passarão por cidades diferentes, com climas diferentes e habitadas por pessoas diferentes. Também terão de enfrentar o Bicho-de-Sete-Cabeças, que cobrará deles certo pedágio para deixá-los passar.

Na segunda, o protagonista é Riquefique, marinheiro experiente cujo barco já estava velho e gasto e, por isso, havia afundado. Degas, Ferrabrás e Beldroegas vão ajudá-lo a construir um novo barco. A partir de então, os quatro seguem rio abaixo, rumo ao mar. No caminho, passarão por cidades diferentes, com climas diferentes e habitadas por pessoas diferentes. Também terão de enfrentar o Bichode-Sete-Cabeças, que cobrará deles certo pedágio para deixá-los passar.

O efeito de apagamento entre as duas histórias dá-se constantemente, por meio do comportamento e das reações das personagens em cada etapa da viagem.

${ }^{439} \overline{\text { Histórias que se apagam, p. } 4 .}$ 


\subsubsection{Histórias embaralhadas. Ilustrações de Ricardo Azevedo. São Paulo, Melhoramentos, 1991. 58 p. \\ (c) 1991 - Leitor-em-processo. Jogo lingüístico com elementos do maravilhoso folclórico.}

Histórias embaralhadas faz parte de uma trilogia de obras (as outras duas são: Histórias espelhadas e Histórias que se apagam) em cujo enredo expressões populares típicas do Brasil se relacionam de alguma maneira, na maioria das vezes em situações completamente inusitadas. Além disso, o desenvolvimento do mesmo tema por meio de diferentes formas de construção textual cria o efeito narrativo enunciado no título, de caráter nitidamente metalingüístico.

Em Histórias embaralhadas narra-se, por meio de três estruturas diferentes, as peripécias de Barroso, o bezerro desmamado que perambula sem destino por paisagens rurais. Medroso e indefeso, Barroso é bezerro sem mãe, que idealiza a liberdade e ao mesmo tempo almeja a segurança que tem o Boi Estrelo

Solto, "livre no campo sem fim" ${ }^{440}$, Estrelo assume o papel de padrinho atencioso, mas não-superprotetor, do novilho. Como alguém pronto para atuar em último caso, somente em situação extrema necessidade, o boi vigia as desventuras de seu afilhado, que não são poucas. Logo de cara, Barroso afunda no brejo. Em seguida, vítima da curiosidade, vê-se prisioneiro de dona Jabiraca e seu Lambisgóia de Uma Figa, que pretendem fazer dele um belo churrasco. O bezerro, no entanto, mesmo sozinho, consegue se libertar, para em pouco tempo quase cair vítima da Onça e da conversa fiada do Amigo da Onça. Numa fuga desenfreada, pelos trilhos da ferrovia, Barroso quase é atropelado pelo trem. Salvou-o a astúcia do maquinista, que consegue frear a tempo. Ao ver-se livre do perigo, o bezerro põe-se a pensar. É quando sente um par de chifres despontando na sua cabeça. Consciente de estar atingindo a maturidade, Barroso sabe intimamente que vai se tornar um touro, tão forte e valente como o Boi Estrelo.

O baralhamento a que se refere o título dá-se por meio do recurso utilizado pelo autor de contar a mesma história três vezes, organizada cada vez por uma seqüência narrativa diferente: "O pé no caminho", "A boca no mundo", "Olho vivo, orelha em pé". Conforme dizem os editores, em Histórias embaralhadas, Lino de Albergaria "recria, com humor poético, três contos que se complementam e fala

\footnotetext{
${ }^{440}$ Histórias embaralhadas, p. 4.
} 
seriamente do medo de crescer, sair para o mundo, viver os tombos e tropeços naturais do caminho de cada um".

\subsubsection{A palavra perdida. Ilustrações de Cecília Iwashita. 15. ed., São} Paulo, Atual, 1991. 56 p.

\section{(C) 1991 - Leitor-em-processo. Maravilhoso metafórico}

Rafael é grandão, Tininha é pequena. Tanto é que o avô Janjão chama a neta de dona Fada e o neto de seu Gigante. A história começa quando os pais de Rafael e Tininha estão de saída para a maternidade. De tão afobados, quase esquecem os filhos. Já dentro do carro é que se lembram de buzinar para chamá-los. A caminho do hospital, deixam os dois na casa do avô, onde também morava um casal de gatos: Flor e Félix.

Por causa da pressa, as crianças são largadas mesmo do lado de fora, no passeio da residência. Isso não era grande problema, pois bastava um toque na campanhia e logo já se ouvia o barulho arrastado dos chinelos de Janjão. Mas nesse dia foram mais de uma dúzia de toques e nada de o avô aparecer. O único ruído que as crianças ouviram foi o das unhas de um gato, arranhando a porta pelo lado de dentro.

Levando a mão à maçaneta, Rafael abriu a porta. Apesar do ambiente meio escuro, tudo na sala parecia como de hábito: livros abertos sobre a mesa, jornais desfolhados em cima do sofá. Mas onde estava o avô? Os gatos pareciam saber e, de modo bem peculiar, fizeram as crianças compreender que deveriam segui-los. Assim, subiram ao andar superior e foram conduzidos até o escritório, cuja porta não estava trancada.

Lá dentro estava Janjão, meio que perdido no meio de um monte de livros abertos sobre a mesa. Completamente absorto, só se deu conta da chegada de Rafael e Tininha quando os dois o chamaram. Tanto o avô não sabia o motivo daquela visita inesperada, quanto os netos não tinham idéia sobre o que ele pesquisava. Depois de alguma conversa, tudo se esclareceu. Janjão percebeu o ciúme que as crianças estavam sentindo do irmãozinho ou irmãzinha prestes a nascer. O menino e a menina descobriram que o avô procurava por uma palavra perdida, esquecida pelos falantes do Português do Brasil. 
A partir desse mote, Tininha e Rafael embarcam em uma longa e mágica aventura, vivenciada no espaço em que se confundem sonho e imaginação. Engolidos por uma bola, viajam até a lua. Mas essa lua é diferente daquela que se conhece por meio da ciência, lembra um pouco a Terra do Nunca, de Peter Pan, criada por James Matthews Berrie. Na lua de A palavra perdida vive o João da Lua, espécie de duplo do avô. Lá também habitam fadas, parecidas com Sininho, e moram gigantes de pedras, só aparentemente assustadores, espécies de duplos dos protagonistas. É ainda lá que se localiza a Cidade do Sumiço.

A diferença dessa lua com a Terra do Nunca é que, nesta, as crianças não querem crescer, naquela, elas conquistam realizações, habilidades e competências, desenvolvem-se emocionalmente, adquirem consciência de seu próprio valor e fortalecem a auto-estima, ao encontrarem a palavra que havia desaparecido. Com isso, aprendem a controlar o ciúme.

\subsubsection{Tangolomango. Ilustrações de Isabel Cristina Passos. Belo Horizonte, Miguilim, 1990. 32 p.}

(C) 1990 - Leitor-em-processo. Realismo mágico.

No Dicionário Aurélio, tangolomango, variação de tanglomanglo, significa doença atribuída a feitiçaria; malefício, bruxedo, sortilégio. Na linguagem popular, dar o tangolomango tem o sentido de morrer, ir para a cidade de pés juntos, comer capim pela raiz. O termo designa também uma cantiga de roda que, no final de cada verso, uma menina deixa o brinquedo: "Eram nove irmãs numa casa / Uma foi fazer biscoito; / Deu o tangolomango nela, / Não ficaram senão oito!". E as meninas, uma de cada vez, vão saindo da brincadeira, até que só fica uma: "Era uma, meu bem, que ficou / Meteu-se a comer feijão; / Deu o tangolomango nela, / Acabou-se a geração!". 441

Seja pelo tema seja pela estrutura, tangolomango inspirou poetas e compositores, como Menotti del Picchia e Adoniran Barbosa, por exemplos. Também serviu de referência para escritores de literatura de infantil, entre os quais Tatiana Belinky e Pedro Bandeira. Assim, a partir da matriz folclórica, foram (e ainda continuam) surgindo novas versões de tangolomango. Os tangolomangos,

${ }^{441}$ LÓSSIO, Rúbia. Tangolomango. Dicionário de folclore para estudantes. Fundação Joaquim Nabuco. s/d. Disponível em: http://www.soutomaior.eti.br/mario/paginas/dic t.htm. Acesso em: 19 jan. 2007. 
geralmente, começam com nove ou dez elementos (filhos, gatinhos, sacizinhos, etc.) e terminam quando acontece alguma coisa com o último, de modo a não sobrar nenhum. O esquema, entretanto, não se reproduz neste Tangolomango, de Lino de Albergaria.

A primeira diferença, já se nota na epigrafe da obra:

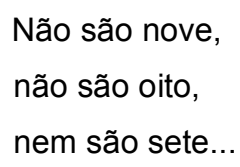

Parte-se, portanto, do número seis. Em segundo lugar, o autor inova no gênero. Em vez de poema ou cantiga, o que se tem é um texto em prosa, no qual Tangolomango é uma cidade localizada no meio de dois rios: Tango e Mango. De um lado a outro, contam-se sete ruas, com características diferentes e nomes que começam com a letra "R".

Às margens do Tango, em uma casa grande e confortável, com horta no quintal e loja de objetos para o lar à frente, moram as irmãs Terra - Rosa, Violeta e Branca. As três são ricas e revezam-se entres as tarefas domésticas e profissionais. No extremo oposto, à beira do Mango, fica o casebre dos Marinho, os irmãos Miguel, Manuel e Menelau. Eles são pobres e todos os dias saem para trabalhar: na biblioteca, consertando livro; no cinema, passando filmes; na banda da cidade, tocando prato; respectivamente. Em comum às personagens há o gosto de olhar para a Lua, seja no céu ou mesmo refletida nas águas dos rios.

Tudo segue rotineiramente calmo na pequena e pacata cidade até o dia em que o dragão, ameaçado por São Jorge na face do satélite, volta à Terra e amedronta os habitantes de Tangolomango. Munidos de livro, música e cinema, os Marinho enfrentarão o mitológico monstro que lança fogo pelas ventas. Miguel tem a palavra; Menelau, o ritmo; Manuel, o movimento. Será que as três armas serão suficientemente poderosas para vencer o inimigo? Descobrir a resposta é o que propõe Lino de Albergaria ao leitor, ao mesmo tempo em que tece, com sutileza, notória crítica social.

O texto, que mescla elementos do realismo mágico e do conto maravilhoso, ficou em segundo lugar no Prêmio Heriqueta Lisboa de Literatura Infantil, edição 
1998, e foi selecionado para o programa Cantinho da Leitura, da Secretaria Estadual de Educação de Minas Gerais, biênio 1997-1998.

\subsubsection{Quem era ela? Ilustrações Rosa Schettino. Belo Horizonte, Lê,} 1990. $16 \mathrm{p}$.

\section{(C) 1990 - Leitor-em-processo. Realismo lúdico}

A descoberta do prazer da leitura, afirmam os especialistas em educação, só pode ocorrer plenamente quando não atrelada a atividades pedagógicas obrigatórias. Exigir que crianças e jovens prestem conta de maneira formal, isto é, por meio de processos avaliativos ortodoxos, a respeito do teor do que lêem serve apenas para afastá-los dos textos.

É a compreensão a respeito desse fato que está na base de construção do enredo de Quem era ela?, em que três meninos das primeiras séries do ensino fundamental, instigados pela presença na escola da recém-contratada bibliotecária, acabam casualmente percebendo o valor intrínseco dos livros.

Ao entrarem na biblioteca movidos pela própria curiosidade, Alex, Serginho e Beto percebem a variedade de obras ali presentes, tanto referentemente ao conteúdo quanto à linguagem e à forma gráfica. Daí, a desenvolverem o hábito da leitura, será um passo.

Mais do que servir de estímulo para que crianças aprendam a gostar de ler, Quem era ela? demonstra aos professores preocupados com o assunto que o maior desafio que têm pela frente é o de encontrar maneiras de despertar o interesse.

\subsection{Leitor iniciante}

A julgar sobre a ótica da psicanálise, a criança alcança a fase do leitor iniciante nos momentos em que ocorre o declínio do conflito edipiano. Sucedem-se a partir daí estágios de desenvolvimento mais acelerado do ego, que envolvem uma consolidação do superego. Em outras palavras, dá-se um processo intenso de socialização e racionalização da realidade. Coincidentemente, nessa época inicia-se a aprendizagem da leitura e da escrita, na qual a criança começa a entrar em 
contato com os signos lingüísticos. O movimento de intensa transformação provoca a busca por modelos comportamentais no mundo adulto. Explica Blos ${ }^{442}$.

A mobilidade, a linguagem e as experiências sociais ampliam o espaço vital da criança e lhe dão consciência da conveniência de ser como os outros e, o que é mais importante, como os pais ou irmãos. Esse empurrão para a vida enche a criança [...] do desejo de tomar o lugar do pai ou da mãe, ou de cada um deles alternadamente, na verdade simultaneamente. Uma conseqüência lógica da dependência em que a criança se encontra em relação ao adulto leva-a a acreditar que, assumindo o papel do genitor do mesmo sexo, conseguirá os atributos desejados do progenitor substituto, atributos que são tão admirados e invejados pela criança.

O estabelecimento de contato com o mundo externo, a partir dessa "imitação" do genitor do mesmo sexo, cria na criança a necessidade de dar sentido a tudo que Ihe rodeia. Sob esse aspecto, a distinção nítida dos traços de caráter e das formas de comportamento é um dado extremamente marcante do período. Assim, é fundamental que a literatura voltada para essa faixa etária coloque em evidência personagens, sejam reais ou simbólicas, inequivocamente circunscritas dentro dos limites do bem e do mal, da coragem e da covardia, da beleza e da feiúra, entre outras polaridades. Coelho ${ }^{443}$ esclarece a respeito dessa necessidade.

Embora o maniqueísmo seja atualmente recusado como visão de mundo, a verdade é que para as crianças (cujo conhecimento de mundo está ainda em formação) essa delimitação é necessária. Mais tarde, a ambigüidade das realidades será descoberta... mas, nesse momento, já terão assimilado parâmetros para julgamento.

Conquanto histórias ambientadas na realidade desempenhem função importante, a fantasia ainda exerce papel de destaque no desenvolvimento psíquico do leitor iniciante. Deve-se atentar para o fato de que a atitude das crianças diante do texto é bem diferente da que os adultos apresentam. Elas relacionam-se,

${ }^{442}$ BLOS, Peter. Adolescência: uma interpretação psicanalítica. 2.ed., São Paulo, Martins Fontes, 1998, p. 9.

${ }^{443}$ COELHO, Nelly Novaes. Literatura infantil: teoria, análise, didática. São Paulo, Moderna, 2000, p. 35. 
sobretudo, com a qualidade pictórica das palavras. Dessa forma, enredos pertencentes exclusivamente aos gêneros do maravilhoso, ou mesmo que mesclem o fantástico com acontecimentos da vida cotidiana, são fortemente recomendados, desde que estimulem a inteligência, a imaginação e o sentimento, entre outras potencialidades.

Os textos de Lino de Albergaria para essa fase da formação infantil vão ao encontro das necessidades aqui apontadas. Em alguns, o elemento mágico é empregado como forma de estimular a intuição. Outros enfocam simples acontecimentos do dia-a-dia a partir da ótica da sensibilidade, em detrimento do pragmatismo tão corriqueiramente esperado.

\subsubsection{Coração conta diferente. Ilustrações de Mariângela Haddad. São} Paulo, Scipione, 1996. 24 p.

(C) 1996 - Leitor iniciante. Realismo humanista.

$\mathrm{Na}$ sala de aula, a professora chama os alunos para resolverem contas na lousa. Adriana erra na multiplicação e é motivo de riso para a maioria dos colegas, menos para Tiago. Em vez de observar o resultado, escrito errado no quadro, o menino prefere reparar na letra redonda e nos cabelos soltos da menina. Essa é a matemática do coração, que obedece apenas a uma única lógica: a do sentimento. A personagem desta história aprende logo a lição.

\subsubsection{O gnomo da pousada. Ilustrações de Isabel Cristina Passos.}

\section{2. ed., Belo Horizonte, Lê, 1992. 24 p.}

\section{(c) 1992 - Leitor iniciante. Realismo mágico.}

Anões e gnomos são divindades minúsculas da forja e da mina, portanto, seres da noite e das cavernas. Donos da terra, do solo e do subsolo têm aspecto muitas vezes repulsivo, uma vez que refletem o subterrâneo de que são hóspedes e guardiões. Vivem no coração da matéria mais densa, mais pesada e sua missão consiste em organizá-la, refiná-la, limpá-la e unificá-la antes de sua saída para a terra. Podem até serem qualificados de feios, mas são muito sábios. 
Nas lendas do folclore popular, esse povo de estatura diminuta assegura a germinação das plantas, escavam galerias em busca de minerais, vigiam o crescimento das pedras preciosas e guardam tesouros enterrados. Os gnomos são tradicionalmente excelentes ferreiros, admiráveis fabricantes de jóias e artesãos de espadas tão fortes e rápidas que tornam invencível quem as usa. Associados às divindades da forja e dos infernos, como o deus grego Hefesto, que forjou o raio de Zeus, guiam e protegem os mineiros e os metalúrgicos.

Por sua etimologia, a palavra gnomo significa o que sabe e também o que vive no interior da terra. Nas culturas francesa e alemã, os gnomos são mencionados a partir do século XIII. Entretanto, sabe-se que, desde o século XI, os habitantes da cordilheira dos Bálcãs já falavam sobres esses seres e evitavam as cavernas exploradas por eles. Seja qual for sua origem, real ou sobrenatural, elemental ou demoníaca, os anões e os gnomos são conhecidos, com nomes diferentes, em todos os países e todas as culturas, inclusive no Brasil. Na França chamam-se gobelins; na Escócia, browales; na Irlanda, cluricaunes; na Suécia, taitters ou tomtes; na Islândia, trolls; na Noruega e na Dinamarca, pruccas ou pwcca; no País de Gales, klabbers, dauniessies, hobgoblis; na Espanha, grasgos ou trasgos; na Suíça, servants, e na Alemanha, nis-kobolds. ${ }^{444}$

A partir da década de 1960, com a difusão do pensamento esotérico, as lendas sobre gnomos tornam-se bastante populares e influenciam a indústria cultural, que passa a colocar no mercado bonecos, filmes, livros e demais produtos inspirados nos habitantes do interior da Terra. Nesse contexto é que, nos anos 1990, Lino de Albergaria escreve 0 gnomo da pousada, no qual narra o relacionamento das irmãs Juliana e Flávia com o gnomo Munte e sua mulher.

Juliana, a mais nova e mais sensível, ia sempre para o mato conversar com o anãozinho. Numa determinada noite, Munte resolveu visitá-la e dar de presente a ela um trevo de quatro folhas. Com a folhinha, a menina começa a ter sorte e a conquistar a amizade dos seres da natureza. Ao descobrir o segredo da irmã, Flávia, a mais velha, sente ciúme e inveja. Fica ansiosa para que Munte goste dela. $O$ gnomo, porém, ranzinza e desconfiado, despreza atitudes não-espontâneas. Antes de merecer a atenção dele, Flávia terá de aprender algumas lições.

${ }^{444}$ VOLPATTO, Rosane. Anões e gnomos. Reino das deusas. Porto Alegre, s/d. Disponível em: http://www.rosanevolpatto.trd.br/anoesgnomos.html. Acesso em: 28 de jan. 2007. 


\subsubsection{A praia dos duendes. Ilustrações de Isabel Cristina Passos. Belo} Horizonte, Lê, 1992. 24 p.

(c) 1992 - Leitor iniciante. Realismo mágico.

Duendes são elementais da Terra, guardiões do reino vegetal. Vivem nas árvores, matas e florestas. São descritos pela tradição popular como pequenos anões, cuja estatura pode variar de dez a 30 centímetros de altura. Têm corpos esverdeados, às vezes com grande quantidade de pêlos, e pés em forma de folhas. $O$ rosto lembra o de um velho, com sobrancelhas acinzentadas, olhos pequenos e redondos, tez avermelhada, curtida pelo sol e pela chuva, barba e bigode. Alguns possuem orelhas grandes e pontudas. Os representantes de certas tribos são baixos e atarracados, gordos e roliços, de membros curtos; já outros são magros e de aparência jovial. É comum manterem expressão cândida, cordial e bucólica. ${ }^{445}$

Em geral, os duendes adotam um estilo medieval de vestuário. Usam pequena túnica marrom, quase sempre guarnecida por uma ampla gola, com debruns de cor verde e botões brilhantes. Completam o traje, calções marrons, meias rústicas e dois tipos de calçado: ora uma bota longa e pesada, ora um sapato de bico fino, de material mais leve. A cabeça normalmente é coberta por uma touca longa e pontuda, mas há aqueles raros que usam chapéu duro e de abas curtas. Como seu elemento é a terra, apresentam muita coisa comum com a simplicidade tosca do lavrador.

Essas pequenas criaturas são, por natureza, comunicativas e amistosas. Alegres, amam festas, músicas e danças. Adoram comer e fazer brincadeiras, como esconder objetos, embora trabalhem de forma esforçada. Andam em bandos, vivem vários anos e chegam a constituir famílias. Muitos duendes são de temperamento avaro e gostam de acumular coisas escondidas longe, em plantas secretas. O comportamento geral desses minúsculos seres baseia-se nas atitudes humanas, por estarem próximos aos homens. Essa aproximação sempre é favorecida quando o ser humano está mais frágil e sensível.

Dizem as lendas que os duendes conseguem controlar imprevistos da natureza e que as crianças pequenas freqüentemente podem vê-los, na medida em

${ }^{445}$ DUENDES. A casa do bruxo: textos sobre magia e esoterismo. s/d. Disponível em: http://www.casadobruxo.com.br/textos/duendes.htm. Acesso em: 26 jan. 2007. 
que seu contato com o lado material ainda não está completo e que elas atuam, mais ou menos conscientemente, nos mundos invisíveis. ${ }^{446}$

Com base nessas crenças, Lino de Albergaria escreve $A$ praia dos duendes, em que três meninos, acompanhados do tio de um deles, viajam de férias para o litoral. Lá, os garotos descobrem uma praia quase deserta, onde existia apenas uma casa pintada de branco, mas já bem suja e abandonada. Havia também umas vaquinhas e um cavalo pastando.

É nesse local que, por conta de uma brincadeira de esconde-esconde, BenHur, o narrador-protagonista entra em contato com um desses pequenos seres. Felipe e Pedro duvidam da palavra do amigo. Consideram o fato, simplesmente, absurdo. Como se pode prever, um clima de mal-estar instala-se entre eles. Só mesmo alguém de mente aberta e sensível poderia socorrer o menino, e ajudá-lo a provar que não era louco nem mentiroso.

7.4.4 A caverna dos elfos. Ilustrações de Isabel Cristina Passos. 2. ed., Belo Horizonte, Lê, 1992. 24 p.

(C) 1992 - Leitor iniciante. Realismo mágico.

É na península escandinava (formada pela Finlândia, Noruega e Suécia) que se encontram as mais belas descrições dos elfos, seres de natureza intermediária entre os homens e os anjos, que dominam os segredos da natureza e das ervas mágicas. Além disso, são amantes da música, da dança e das artes; conhecem os astros, viajam sobre os raios do sol e podem atravessar qualquer elemento, embora prefiram a cercania das águas.

Essas pequenas criaturas medem de 25 a 30 centímetros. Em sua compleição, apresentam pernas extremamente finas e possuem mãos e pés grandes, se comparados ao resto de seu corpo. As orelhas e narizes são pontiagudos e as bocas muito largas. A pele é geralmente rugosa, mas a cor varia segundo a tribo a que pertencem. Existem os elfos de luz e os elfos escuros.

Os elfos claros ou luminosos têm corpos transparentes e fluídicos. Os olhos são claros, azuis ou verdes, e os cabelos quase brancos. Vivem nos grandes bosques e vestem roupas verdes, para camuflarem-se entre as folhas das árvores.

${ }^{446}$ VOLPATTO, Rosane. Anões e gnomos. Reino das deusas. Porto Alegre, s/d. Disponível em: http://www.rosanevolpatto.trd.br/anoesgnomos.html. Acesso em: 28 de jan. 2007. 
Constroem casas requintadas e bem decoradas, mas sempre muito ocultas, já que não fazem amigos com facilidade e, sobretudo, procuram se manter afastados dos humanos. Para evitar serem vistos, saem somente à noite.

Todas as cidades dos elfos de luz são dotadas de grande beleza, graças ao bom gosto e à habilidade que demonstram em todas as tarefas que empreendem. Além disso, adoram celebrar grandes banquetes e promovem festas muito animadas com alegres músicas. Preferem passar breves momentos felizes a longos períodos tristes. Filosoficamente falando, são partidários do "viver o agora", de modo a desfrutar da melhor maneira possível cada momento que passa.

Como as fadas, os elfos desempenham papel de equilíbrio na saúde e no crescimento das plantas. Enquanto os gnomos cuidam da semente subterrânea, as fadas do broto da planta fora do solo, os elfos cuidam de que o sol a toque e do mecanismo da fotossíntese.

Os elfos recebem os nomes de: nis, na Alemanha; nis-god-drange, na Dinamarca e Noruega; tylwithes, na Inglaterra; duende, na Espanha; esprit follet, na França. Na Escócia, distinguem-se os dun-elfen (elfos das dunas), os berg-elfen (elfos das colinas), os munt-elfen (elfos das montanhas), os wudu-elfen (elfos dos bosques) e os woeter-elfen (elfos das águas). Na Irlanda, são conhecidos com o nome de daoine side, (habitantes das colinas das fadas), pois, segundo dizem, esses espíritos ocupam magníficos palácios subterrâneos dissimulados no interior dos verdes montes das pradarias irlandesas. ${ }^{447}$ É exatamente num cenário parecido com esse que Isalino de Albergaria ambienta o seu $A$ caverna dos elfos.

Em alguma localidade rural brasileira, Tiago costumava passar as férias na casa de seus primos Ronald e Raquel. Certo dia, depois de cavalgarem bastante, os três resolveram fazer um passeio a pé. De repente, em pleno período da tarde, o que não era normal, foi-se formando uma densa neblina em volta deles. A visão do caminho ficou completamente prejudicada. Andando lentamente em meio à forte cerração, eles chegaram ao interior de uma gruta. Lá, assistiram a um "curioso" bailado de elfos, conversaram com o rei dos elfos e fizeram um juramento.

Depois dessa experiência, Ronald, Raquel e Tiago fundaram a Sociedade dos Lírios Brancos. Qual o objetivo da associação? Esse é um segredo, que deve ficar guardado entre as personagens da história e, certamente, o leitor.

${ }^{447}$ VOLPATTO, Rosane. Elfos. Reino das deusas. Porto Alegre, s/d. Disponível em: http://www.rosanevolpatto.trd.br/elfos1.html. Acesso em: 28 de jan. de 2007. 


\subsection{Pré-leitor}

Por meio das brincadeiras e dos jogos imaginativos das crianças podem-se conhecer melhor as fantasias, os desejos e as experiências reais que elas vivenciam. A forma de expressão desses conteúdos dá-se com o emprego, por assim dizer, do mesmo tipo de linguagem característica dos sonhos, isto é, simbólica. O brincar da criança é parte de seu comportamento como um todo e assim deve ser considerado quando se trata de programar práticas facilitadoras do desenvolvimento. Especializada no trabalho analítico voltado para a primeira e a segunda infância, Klein ${ }^{448}$ testemunha:

A análise de crianças muito pequenas tem mostrado repetidamente quantos significados diferentes pode ter um único brinquedo ou um único segmento de uma brincadeira e que só podemos inferir e interpretar o seu significado quando consideramos suas conexões mais amplas e a situação analítica em que se inserem. [...] Se utilizarmos a técnica do brincar, logo descobriremos que a criança traz tantas associações aos elementos separados da sua brincadeira quanto os adultos com os elementos separados de seus sonhos. Esses elementos separados do brincar são indicações para o observador experiente; e, enquanto brinca, a criança também conversa e diz toda sorte de coisas, que têm o valor de genuínas associações.

O mesmo pode-se dizer com relação à leitura. $\mathrm{O}$ fato de o pré-leitor ainda não estar apto para fruir sozinho o conteúdo pleno de uma obra literária favorece o processo de interação entre criança e adulto, assim como qualquer jogo ou brincadeira. Livros criados especialmente para esse estágio do desenvolvimento criam situações propícias à catarse da criança com relação aos fatos narrados, com efeitos benéficos para a resolução de conflitos inconscientes. Por ser um período marcado pela conquista da linguagem, pelo egocentrismo e pelo animismo, textos que estimulem o autoconhecimento, a relação com os fenômenos naturais e com os objetos do cotidiano exerce um papel preponderante para a formação psíquica.

A fase em que se encontra o pré-leitor costuma coincidir com a descoberta do mundo concreto e a nomeação das realidades à sua volta. Essas experiências

${ }^{448}$ KLEIN, Melanie. A psicanálise de crianças. Trad. Liana Pinto Chaves. Rio de Janeiro, Imago, 1997, p. 28. 
podem causar medo, decorrente da chamada ansiedade arcaica. ${ }^{449}$ Segundo psicanalistas, a criança experimenta desde muito cedo (a partir dos seis meses) conflitos decorrentes do complexo de Édipo. Mesmo sem saber, culpa-se por sentir essas sensações. Por essa razão, desenvolve comportamentos agressivos, que podem projetar-se para o mundo externo, em casos de transferência negativa. Nesse sentido, a literatura própria para esse estágio configura-se como forte aliada para o alcance do equilíbrio emocional.

Coelho $^{450}$ esclarece que os livros mais apropriados para o pré-leitor são aqueles que propõem "vivências radicadas" no cotidiano familiar à criança e que apresentem determinadas características, tais como predomínio absoluto da imagem (produzida por diferentes meios plástico-artísticos), repetição ou reiteração de elementos, humor e certo clima de expectativa ou mistério.

Nos textos voltados para essa fase, Lino de Albergaria demonstra-se preocupado em trabalhar temas e formas de linguagem que favoreçam a plena adaptação ao meio físico e o crescente interesse da criança pela comunicação verbal.

Ditos populares e efeito de oralidade constituem, respectivamente, a matériaprima e a técnica com que Lino de Albergaria compõe a série de Dona Zaga e Zé Biludo.

\subsubsection{Dona Daga e Zé Biludo. Ilustrações de Luiz Rodrigues. São Paulo, Edições Loyola, 1994. 16 p.}

\section{(C) 1994 - Pré-leitor. Realismo lúdico e mágico.}

A descoberta do prazer da leitura é tarefa que se inicia na mais tenra infância. Para que esse processo se desenvolva de forma plena, é essencial que os adultos estimulem os sentidos a criança. Entre esses, sobretudo o ouvir exerce papel fundamental para a formação de leitores proficientes. Sob esse aspecto, as cantigas de ninar, os poemas, e demais gêneros textuais ricos em efeitos sonoros constituem importante material de apoio a pais e educadores.

\footnotetext{
${ }^{449}$ Conforme KLEIN, Melanie. A psicanálise da criança. Trad. Liana Pinto Chaves. Rio de Janeiro, Imago, 1997.

${ }^{450}$ COELHO, Nelly Novaes. Literatura infantil: teoria, análise, didática. São Paulo, Moderna, 2000, pp. 33-4.
} 
Em Dona Daga e Zé Biludo, Lino de Albergaria emprega recursos estilísticos da língua de modo a obter como resultado a criação de expressivos efeitos de oralidade. Ditos populares, rimas e onomatopéias emprestam ritmo melodioso ao texto, especialmente se lido em voz alta. Só mesmo a reprodução de um trecho pode dar exemplo do tom da narrativa:

D. Daga morava sozinha na última casa do fim da rua. Todo dia, ela ia comprar ovo, leite e farinha no armazém do seu Borém, a primeira casa do começo da rua.

— Taque-taque... taque-taque... — fazia o saltinho do sapato de $D$. Daga batendo no chão da rua, e logo se abria uma janela. Depois outra. Depois mais uma. Logo se abraim as janelas todas da rua. ${ }^{451}$

De modo a explorar o vasto acervo de expressões populares do Português do Brasil, o autor produz uma série de cinco livros (os outros são $A$ galinha do vizinho $e$ a vaca amarela, O sumiço do botão, O dia da caça, O bolo das vizinhas.), nos quais D. Daga e Zé Biludo são personagens principais.

\subsubsection{O sumiço do botão. Ilustrações de Luiz Rodrigues. São Paulo, Edições Loyola, 1994. 20 p.}

(C) 1994 - Pré-leitor. Realismo lúdico e mágico.

D. Daga é uma velinha que mora sozinha e fala com os objetos. Quando está em casa, costuma chamar: "Bule?" E o bule responde: "Aqui". "Xícara?", grita a mulher. "Aqui", retruca a xícara. E assim por diante.

Quando vai pela rua, D. Daga conversa com os botões. Eles são três: o de cima, o do meio e o debaixo. As pessoas da vizinhança costumam dizer que a velinha é meio doida. Mas ela nem liga, até porque não gosta de quase ninguém. Seu único amigo é o Zé Biludo, filho do seu Borém, o dono do armazém. A amizade entre eles nasceu já no primeiro livro, quando a velha percebeu que o Zé Biludo era meio parecido com ela, pois conversava com o zíper da jaqueta dele.

D. Daga sempre faz bolo e, naquele dia, guardou um pedaço para o Zé Biludo. O tempo, no entanto, ia passando e nada de o rapaz aparecer. Ela então resolveu ir atrás dele, sempre conversando com os botões. Já ia a meio do caminho

${ }^{451}$ Dona Daga e Zé Biludo, p. 3. 
quando percebeu que só dois deles Ihe respondiam. "O botão lá debaixo tinha tomado chá de sumiço... Evaporou... Casou, mudou, não te convidou..." ${ }^{452}$ Pronto, estava armada a confusão, que só seria resolvida com a ajuda do amigo Zé Biludo.

\subsubsection{O bolo das vizinhas. Ilustrações de Luiz Rodrigues. São Paulo,} Edições Loyola, 1995. 24 p.

\section{(c) 1994 - Pré-leitor. Realismo lúdico e mágico.}

Naquele dia, o bolo de D. Daga estava mais cheiroso do que nunca. Tanto, que o aroma foi entrando pelas janelas das vizinhas. D. Maria, D. Lia e D. Ana lamberam até os beiços. Quem também ficou com água na boca foi o seu Bebé, que vinha passando pela rua. Ele então parou. Espiou pela janela para dentro da casa de D. Daga. Como não viu ninguém, e "a ocasião faz o ladrão" ${ }^{453}$, resolveu furtar o bolo da velhinha.

Enquanto isso, as vizinhas, puseram-se a desdenhar:

— Fum! Que fedor de bolo estragado! — falou D. Maria.

—É bolo solado! — falou D. Lia.

— Que nada, isso é bolo queimado! — falou D. Ana. ${ }^{454}$

Com o barulho, D. Daga pegou seu Bebé com a "boca na botija" ${ }^{455}$. Chegou a tempo de salvar o bolo e convidou apenas o Zé Biludo para comer um pedaço. Despeitadas, as vizinhas resolveram também fazer um bolo, especialmente para o seu Bebé. Resta saber como a história termina.

\subsubsection{A galinha do vizinho e a vaca amarela. Ilustrações de Luiz Rodrigues. São Paulo, Edições Loyola, 1994. 16 p. \\ (C) 1994 - Pré-leitor. Realismo lúdico e mágico.}

Dona Daga pintou o cabelo de azul, colocou uma rede por cima do coque, e resolveu sair. Não era dia de fazer bolo nem de cuidar da casa. Toda arrumada, D.

\footnotetext{
${ }^{452}$ O sumiço do botão, p. 8.

${ }^{453} \mathrm{O}$ bolo das vizinhas, p. 5 .

454 Ibidem, p. 7.

455 Ibidem, p. 7.
} 
Daga desceu a rua. Estava tão bonita que chamou a atenção do seu Bebé. Na porta da vizinha, tinha uma galinha. Um dos botões de D. Daga logo se manifestou:

- A galinha do vizinho bota ovo amarelinho. ${ }^{456}$

Ao chegar ao armazém, D. Daga não quis saber de comprar nada. Só perguntou ao seu Borém onde estava o Zé Biludo. Ele tinha ido para mato, pescar no córrego. Lá foi então D. Daga, atrás do seu amigo. No caminho, tinha uma vaca amarela. E nem é preciso dizer o que disseram os botões de D. Daga.

Naquele dia, em vez de bolo, D. Daga e Zé Biludo comeram mas foi bastante piaba, muito bem frita com farinha.

\subsubsection{O dia da caça. Ilustrações de Luiz Rodrigues. São Paulo, Edições} Loyola, 1995. 24 p.

(C) 1994 - Pré-leitor. Realismo lúdico e mágico.

Em O dia da caça, D. Daga demonstra toda sua implicância com seu Bebé, tipo galanteador, exibido e garboso, que desperta o interesse das mulheres da vizinhança. D. Maria, D. Lia e D. Ana derretem-se em mesuras e comentários quando ele passa.

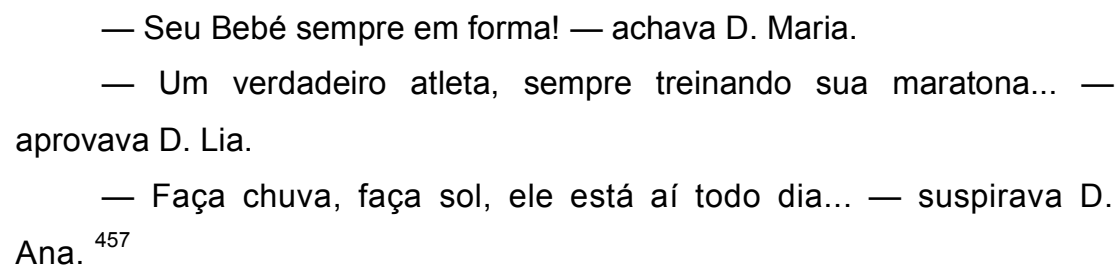

Na opinião de D. Daga ele é, mas sim, muito do folgado. Não faz nada o dia inteiro e só fica pela rua a intrometer-se na vida alheia. Nas idas e vindas, rua acima, rua abaixo, a velha volta e meia encontra com ele. Seu Bebé diz um gracejo. A mulher responde mal. Em outra oportunidade, é dona Daga quem zomba com ele. Mas a velha não perde por esperar, o homem fica só aguardando a chance de darIhe o troco.

\footnotetext{
${ }_{456}$ A galinha do vizinho e a vaca amarela, p. 5.

${ }^{457}$ O dia da caça, p. 9.
} 


\subsubsection{Labirinto. Ilustrações de Marcus Vinicius. 2.ed., Belo Horizonte,} RHJ, 1991. 12 p.

(C) 1991 - Pré-leitor. Realismo lúdico.

Em Labirinto, João explora um espaço cuja única finalidade é servir à circulação. Entre as portas fechadas dos corredores de um edifício, vira e mexe fragmentos de histórias individuais insinuam-se de forma fugaz. Um gato fugitivo, o olhar austero de um homem segurando o jornal, crianças alegres no elevador revelam o pulsar da vida no interior daquela construção.

A leitura de textos desse tipo configura-se como importante auxiliar para o processo de sublimação dos impulsos agressivos, com a conseqüente diminuição dos medos do mundo externo.

\subsubsection{O sonho. Ilustrações de Pink Wainer. São Paulo, Salesiana Dom Bosco, 1989. 16 p. \\ (c) 1989 - Pré-leitor. Realismo mágico.}

Entre as personagens de Lino de Albergaria, a maioria sonha. A presença do mar nas histórias do autor também é uma constante. É a partir desses dois temas que se constrói o enredo deste pequeno livro para o pré-leitor.

Joaquim, ao deitar-se, sonha com o raio de uma estrela que o leva ao mar. Pelo mesmo raio, desce uma espécie de duplo do menino, que ocupa seu lugar na cama. A divisão da personagem sugere o contato com o inconsciente.

$\mathrm{Na}$ praia, vaidosas e afetuosas sereias surgem das ondas espumantes do oceano. As imagens oníricas representam o diálogo de Joaquim com a polaridade passiva, feminina, da psique.

Os primeiros sonhos de uma criança revelam, sob a forma simbólica, a estrutura básica dos diferentes estágios de formação psicológica, indicando como mais tarde o indivíduo irá modelar seu destino.

Dessa forma, ao narrar um sonho infantil por meio de linguagem bastante simples, a obra trata do efeito regulador do contato com o inconsciente para o processo de desenvolvimento psíquico. As ilustrações de Pinky Wainer acompanham a poeticidade do texto. 


\subsubsection{O vento. Ilustrações Paula Seara. 3. ed., Belo Horizonte, RHJ,} 1988. $12 \mathrm{p}$.

\section{@) 1988 - Pré-leitor. Realismo lúdico}

Conforme explica Piaget ${ }^{458}$, no animismo infantil a tendência é tomar as coisas vivas como dotadas de intenção. A criança considera ser vivo todo objeto que exerça uma atividade. A lâmpada que acende; o forno que esquenta.

Depois, a vida estará destinada aos agentes e corpos que parecem-se mover por si próprios, como os astros e o vento. [...] Mais tarde, só o movimento espontâneo será dotado de consciência. Por exemplo, as nuvens não sabem mais "porque o vento as empurra"; mas o vento não sabe as coisas "porque não é uma pessoa" como nós, mas "sabe que sopra, porque é ele quem sopra". 459

É o caso deste $O$ vento, em que Clarisse, de forma lúdica e imaginativa, observa e reconhece essa força da natureza. Além das nuvens, o vento levanta as folhas do chão, o vestido e os cabelos da menina. Enfim, o vento agita tudo, até a água do laguinho. E estimula a imaginação. Será que tem uma fada, um gênio morando dentro do vento? Será um saci rodando no redemoinho?

A idéia do autor de associar o vento a seres mitológicos e folclóricos, além de responder ao animismo próprio da faixa etária, prepara a criança para o desenvolvimento de leituras intertextuais.

\subsubsection{Série $A$ casa}

Na série $A$ casa, publicada pela editora Globo, o autor inspira-se nos objetos presentes nas residências para representar cenas do cotidiano comuns a qualquer família.

${ }^{458}$ PIAGET, Jean. Seis estudos de psicologia. Trad. Maria Alice Magalhães D’Amorim e Paulo Sérgio Lima Silva. 24.ed., Rio de Janeiro, Forense Universitária, 2002, pp. 30-1.

${ }^{459}$ Idem, ibidem. 


\subsubsection{O espelho. Ilustrações de Ivan Baptista e Marcello Araújo.}

Rio de Janeiro, Rio Gráfica /Globo, 1986. 24 p.

(c) 1987 - Pré-leitor. Realismo lúdico.

Cecília observa o modo como a família se relaciona com o espelho. O pai repara o corpo, murcha a barriga, arranca um fio de cabelo branco. A mãe alisa a saia, dá uma rodadinha, passa batom. O irmão penteia o cabelo, ajeita o topete, espreme uma espinha. A menina brinca de gente grande, imita a vaidade alheia e faz careta para sua imagem refletida.

\subsubsection{O chuveiro. Ilustrações de Ivan Baptista e Marcello Araújo.}

Rio de Janeiro, Globo, 1987. 24 p.

๑) 1987 - Pré-leitor. Realismo lúdico.

A mãe é sempre a primeira a tomar banho. O pai canta, assobia e faz a barba debaixo do chuveiro. Carlinhos, o irmão, faz hora, lê, ouve música no banheiro, mas acaba se lavando. No entanto, é Cecília quem mais se diverte durante o banho. Leva bóia, leva peixinho e até a boneca Cecília Maria.

\subsubsection{A rede. Ilustrações de Ivan Baptista e Marcello Araújo. Rio} de Janeiro, Globo, 1987. 24 p.

(c) 1987 - Pré-leitor. Realismo lúdico.

O canto da sala estava vazio. O pai, certo dia, trouxe uma rede e pendurou bem ali. Cada ente daquela família aproveita a rede de um jeito. Até Jambalaia, a cachorra, quer se balançar. Mas acaba causando a maior confusão.

\subsubsection{A cadeira. Ilustrações de Ivan Baptista e Marcello Araújo.} Rio de Janeiro, Globo, 1987. 24 p.

\section{(c) 1987 - Pré-leitor. Realismo lúdico.}

A cadeira serve para o pai ler o jornal. Carlinhos, o irmão, passa horas nela sentado, falando ao telefone. Para Cecília, a cadeira vira carro, vira fazenda, vira boi empacado. Vira tudo o que permite sua imaginação. 


\subsubsection{Túlio e a chuva. Ilustrações de Regina Rennó. 6. ed., São Paulo,} FTD, 1992. $16 \mathrm{p}$.

(c) 1983 - Pré-leitor. Realismo lúdico e humanitário.

Que criança não gosta de praia?! Que criança ainda não praguejou quando, com tudo pronto para brincar no mar, o céu inventa de nublar e fazer desabar a chuva pesada?! Essa á história de um dia na vida de Túlio, que sonha com castelos enormes, moradas de gigantes, de reis e de fadas, tudo isso construído de areia.

O garoto chora e xinga a chuva. Sente-se a criança mais infeliz de todas. Mas o acaso prepara uma surpresa. Após o desabafo, quando dá por si, está sentado diante da estante de livros. Sem refletir, puxa um deles, puxa outro: estrelas, mapas e paisagens; aventuras de heróis e de meninos. Túlio já não se incomoda mais com a chuva.

\subsubsection{Eurico ri à toa. Ilustrações de Lúcia Vianna Lacourt. 5. ed., São} Paulo, FTD, 1990. 16 p.

\section{(c) 1983 - Pré-leitor. Realismo lúdico e humanitário.}

A alegria de viver, a satisfação de ser criança e poder brincar com os amigos, o bem-estar proporcionado pelo ar, pela água, pelo colorido das flores, pelo contato com os animais são prazeres que Eurico descobre e fazem dele um menino feliz, que ri à toa.

Eurico reporta o leitor a uma época em que as crianças viviam livres e soltas, em que as pessoas moravam em cidades física e psicologicamente saudáveis, e o mundo fora de casa era amável e hospitaleiro. Naqueles tempos, não havia felicidade maior para uma criança do que a de se sentir integrada com a natureza. Talvez seja importante que os meninos e as meninas de hoje saibam disso.

\subsubsection{Naá. Ilustrações de Isabel Cristina Passos. 5. ed., São Paulo, FTD, 1992. $16 \mathrm{p}$.}

(c) 1983 - Pré-leitor. Realismo lúdico e humanitário.

Nas gramáticas normativas, a interjeição é definida como uma espécie de grito por meio do qual alguém traduz de modo vivo as emoções. Entre as 
interjeições descritas no Português do Brasil, uma das mais comuns no uso cotidiano é $a h$ !

Expressão de alegria ou admiração, a interjeição ah! é a forma pela qual Ana, personagem desta história, manifesta suas descobertas a respeito do mundo que a cerca. É ah! que a menina exclama quando tropeça ao aprender a andar, quando tudo fica no escuro, quando derruba sopa na roupa, quando percebe a barriga da mãe crescendo, quando vê no galinheiro o ovo quebrar sozinho e surgir o pintinho.

Ana diz tanto ah!, que seu apelido virou Naá: contração de Ana com ah!. Ana só não disse ah! quando Xando, seu irmãozinho, nasceu. Havia entendido o mistério da barriga da mãe, já sabia andar sem cair, e não tinha mais medo do escuro.

\subsubsection{O patinho feio e outros contos de Andersen. Ilustrações Márcia} Franco. 5. ed., Belo Horizonte, Lê, 2002. 56 p.

(C) 1996 - Conto de fadas. Pré-leitor, leitor iniciante, leitor-emprocesso.

Além de produzir vasta obra autoral, Lino de Albergaria dedica-se a pesquisar e estudar os grandes clássicos da literatura universal para crianças. Em O patinho feio e outros contos de Andersen, o autor reconta, a partir dos textos originais do dinamarquês Hans Christian Andersen, a tradicional história do ovo de cisne chocado pela mãe pata e mais duas menos conhecidas: Os onze cisnes selvagens e João-Pato. 